\title{
The Drought of 1998-2002 in North Carolina Precipitation and Hydrologic Conditions
}

Scientific Investigations Report2005-5053 
Cover. High Rock Lake in Davidson County, North Carolina, June 25, 2002. Photograph by Chuck Liddy, The News and Observer, Raleigh, N.C. Used with permission.

Title page. Pontoon boats along the shoreline of High Rock Lake in Davidson County, North Carolina, June 25, 2002. Photograph by Chuck Liddy, The News and Observer, Raleigh, N.C. Used with permission. 


\section{The Drought of 1998-2002 in North Carolina- Precipitation and Hydrologic Conditions}

By J. Curtis Weaver

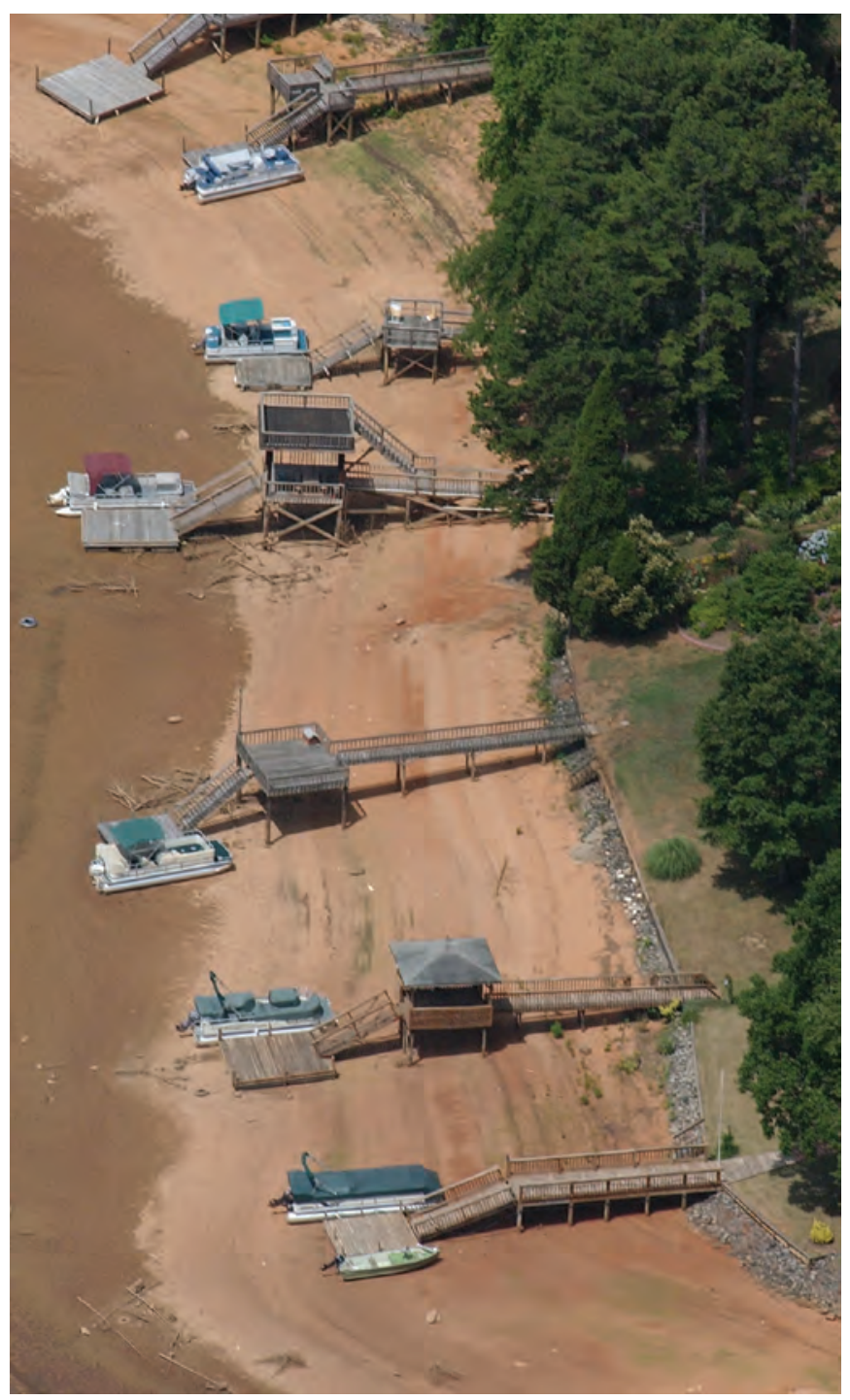

Scientific Investigations Report 2005-5053 


\section{U.S. Department of the Interior \\ Gale A. Norton, Secretary \\ U.S. Geological Survey \\ Charles G. Groat, Director}

U.S. Geological Survey, Reston, Virginia: 2005

For sale by U.S. Geological Survey, Information Services
Box 25286, Denver Federal Center
Denver, CO 80225
For more information about the USGS and its products:
Telephone: 1-888-ASK-USGS
World Wide Web: http://www.usgs.gov/

\footnotetext{
Any use of trade, product, or firm names in this publication is for descriptive purposes only and does not imply endorsement by the U.S. Government.

Although this report is in the public domain, permission must be secured from the individual copyright owners to reproduce any copyrighted materials contained within this report.

Suggested citation:

Weaver, J.C., The drought of 1998-2002 in North Carolina-Precipitation and hydrologic conditions: U.S. Geological Survey Scientific Investigations Report 2005-5053, 88 p.
} 


\section{Contents}

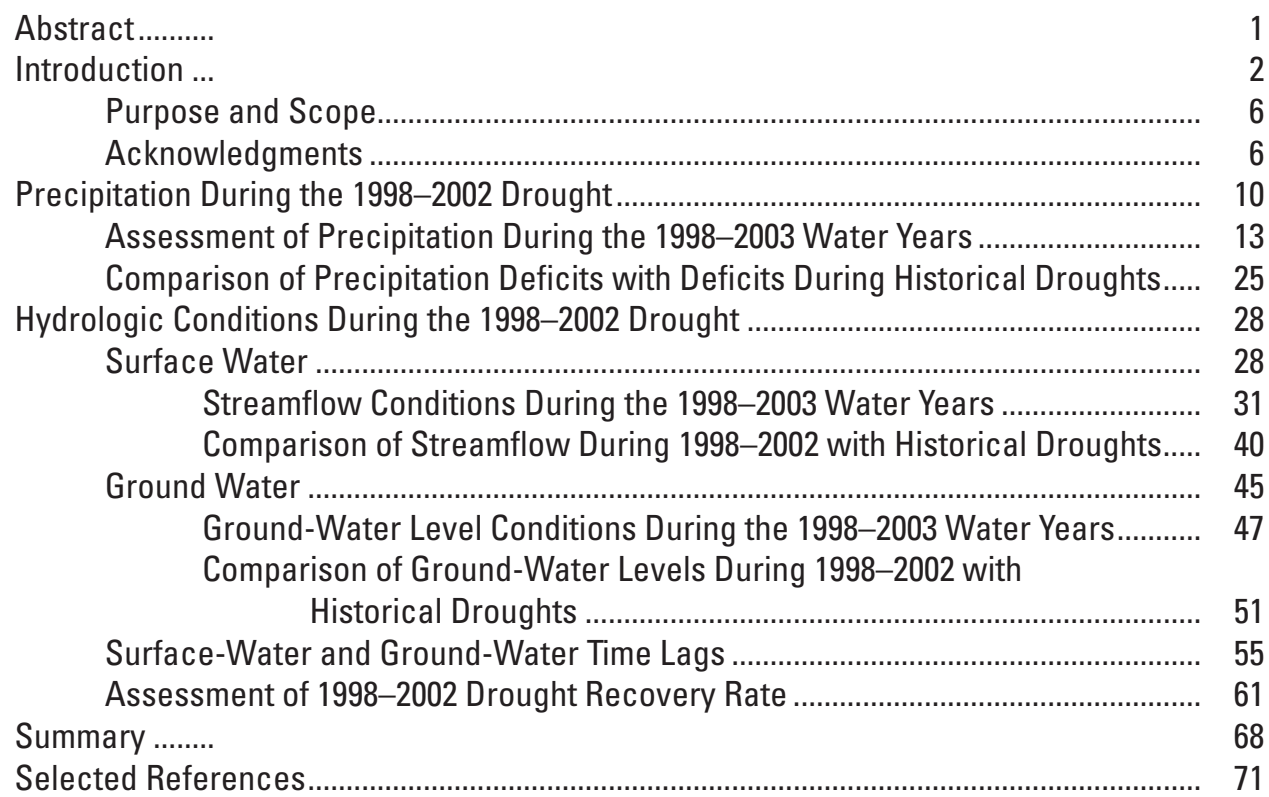

\section{Sidebars}

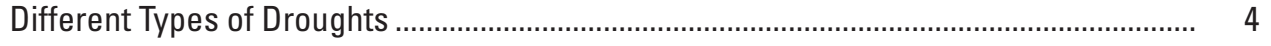

USGS WaterWatch: Providing Real-Time Streamflow Characterization

on the Internet ............................................................................................. 7

Climatic Causes of Droughts in North Carolina .............................................................. 11

Use of Drought Indices to Assess Droughts ................................................................. 20

Characterizing Low-Flow Frequency: Can Droughts Change the 7010 Discharge? ........ 41

Societal Effects of the 1998-2002 Drought in North Carolina ............................................. 63

\section{Figures}

1. Locations of selected features and the physiographic provinces

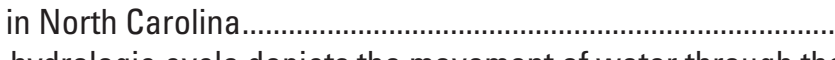

2. The hydrologic cycle depicts the movement of water through the hydrologic system

3. Selected National Oceanic and Atmospheric Administration precipitation stations in North Carolina, 1998-2003.

umulative monthly precipitation departures at selected National Oceanic and Atmospheric Administration precipitation stations in North Carolina by physiographic province, May 1998 through September 2003.

5. Cumulative monthly precipitation departures at the Greenville, N.C., precipitation station, October 1997 through September 2003

6. Cumulative monthly precipitation departures at the Hickory Regional Airport precipitation station in North Carolina, October 1997 through September 2003

7. Cumulative monthly precipitation departures at the Mocksville, N.C., precipitation station, October 1997 through September 2003 
8. Cumulative monthly precipitation departures at the Charlotte Douglas Airport precipitation station in North Carolina, October 1997 through September 2003

9. Percentage of normal moving 12-month precipitation totals for selected National Oceanic and Atmospheric Administration precipitation stations in North Carolina, October 1997 through September 2003

10. (A) Cumulative monthly precipitation departures and (B) precipitation deficits for selected historical droughts at the Hickory Regional Airport precipitation station in North Carolina, January 1949 through September 2003.

11. (A) Cumulative monthly precipitation departures and (B) precipitation deficits for selected historical droughts at the Mount Airy precipitation station in North Carolina, January 1900 through September 2003.

12. Precipitation deficits for selected historical droughts at the Fayetteville Public Works Commission precipitation station in North Carolina.

13. Continuous-record U.S. Geological Survey streamgaging stations in North Carolina having greater than 10 years of record, and locations where recordlow daily mean discharges were set during the 1998-2002 water years

14. U.S. Geological Survey streamgaging stations (68 sites) used in the assessment of "daily" 7-day average discharges and historical streamflow percentiles for each calendar date during the 1998-2002 water years

15. Generalized areas showing number of days in 1998-2003 water years during which 7-day average discharge exceeded the 7-day, 10-year low-flow discharge

16. Generalized areas showing number of days in 1998-2003 water years during which 7-day average discharge exceeded the 7-day, 50-year low-flow discharge.

17. Generalized areas showing number of days in 1998-2003 water years during which 7-day average discharge exceeded the 7-day, 100-year low-flow discharge....

18. Observed 7-day average discharge at South Yadkin River near Mocksville during the 1985-87 and 2001-03 water years.

19. Selected U.S. Geological Survey climate-response observation wells in North Carolina.

20. Ground-water hydrographs at five selected wells in North Carolina, 1998-2003 water years

21. Ground-water hydrograph at NC-146 (site 157, Hornets Nest Park, Mecklenburg County) in North Carolina, 2002.

22. Water levels at NC-40 (site 153, Blue Ridge Paper Products well, Haywood County) during the 1985-90 and 1998-2003 water years

23. Water levels at NC-160 (site 168, Simpson well, Pitt County) during the 1977-82 and 1998-2003 water years

24. Water levels at NC-144 (site 155, Blantyre well, Transylvania County) during the 1982-87 and 1998-2003 water years.

25. Water levels at NC-142 (site 159, Mocksville well, Davie County) during the 1982-87 and 1998-2003 water years

26. Water levels at NC-173 (site 164, Comfort well, Jones County) during the 1990-95 and 1998-2003 water years

27. Cumulative monthly departures of streamflow, ground water, and precipitation for sites at Blantyre, Transylvania County, during (A) 1998-2003 water years and (B) 2002-03 water years 
28. Cumulative monthly departures of streamflow, ground water, and precipitation for sites near Paw Creek, Mecklenburg County, during (A) 1998-2003 water years and (B) 2002-03 water years

29. Cumulative monthly departures of streamflow, ground water, and precipitation for sites near Mocksville, Davie County, during (A) 1998-2003 water years and (B) 2002-03 water years

30. Cumulative monthly departures of streamflow, ground water, and precipitation for sites near Hoffman, Richmond County, during (A) 1998-2003 water years and (B) 2002-03 water years

31. Cumulative monthly departures of streamflow, ground water, and precipitation for sites near Trenton, Jones County, during (A) 1998-2003 water years and (B) 2002-03 water years

32. Drought recovery rates at South Yadkin River near Mocksville (site 85) using cumulative monthly streamflow departures from October 1938 through September 2003

33. Drought recovery rates at French Broad River at Asheville (site 131) using cumulative monthly streamflow departures from January 1900 through September 2003

\section{Tables}

1. Summary of precipitation departures at selected National Oceanic and Atmospheric Administration precipitation stations in North Carolina, 1998-2003 water years

2. Precipitation deficits for selected historical droughts in North Carolina

3. Number of U.S. Geological Survey streamgaging stations in North Carolina where record-low discharges were set during the 1998-2002 water years.... 31

4. Summary of selected site attributes and record-low daily mean discharges at U.S. Geological Survey streamgaging stations having greater than 10 years of systematic discharge records through the 2002 water year in North Carolina.

5. Summary of minimum 7-day average discharges at selected U.S. Geological Survey streamgaging stations during the 1998-2002 drought and other historical droughts in North Carolina.

6. Summary of U.S. Geological Survey observation wells operated during the 2002 water year in North Carolina

7. Summary of site attributes and record-low ground-water levels at selected U.S. Geological Survey climate-response observation wells having greater than 5 years of systematic water-level records in North Carolina as of the 2002 water year

8. Summary of time lags in cumulative monthly departures at selected surface-water and ground-water sites in response to changes in precipitation departures. 


\section{Conversion Factors, Temperature, Datum, and Acronyms and Abbreviations}

\begin{tabular}{|c|c|c|}
\hline Multiply & By & To obtain \\
\hline \multicolumn{3}{|c|}{ Length } \\
\hline inch (in.) & 25.4 & millimeter $(\mathrm{mm})$ \\
\hline foot $(\mathrm{ft})$ & 0.3048 & meter $(\mathrm{m})$ \\
\hline mile (mi) & 1.609 & kilometer $(\mathrm{km})$ \\
\hline \multicolumn{3}{|c|}{ Area } \\
\hline square mile $\left(\mathrm{mi}^{2}\right)$ & 2.590 & square kilometer $\left(\mathrm{km}^{2}\right)$ \\
\hline \multicolumn{3}{|c|}{ Flow } \\
\hline cubic foot per second $\left(\mathrm{ft}^{3} / \mathrm{s}\right)$ & 0.02832 & cubic meter per second $\left(\mathrm{m}^{3} / \mathrm{s}\right)$ \\
\hline $\begin{array}{l}\text { cubic foot per second per square } \\
\text { mile }\left[\left(\mathrm{ft}^{3} / \mathrm{s}\right) / \mathrm{mi}^{2}\right]\end{array}$ & 0.01093 & $\begin{array}{l}\text { cubic meter per second per } \\
\text { square kilometer }\left[\left(\mathrm{m}^{3} / \mathrm{s}\right) / \mathrm{km}^{2}\right]\end{array}$ \\
\hline \multicolumn{3}{|c|}{ Volume per time } \\
\hline inches per year (in/yr) & 2.54 & centimeters per year $(\mathrm{cm} / \mathrm{yr})$ \\
\hline
\end{tabular}

Temperature: In this report, temperature is given in degrees Fahrenheit $\left({ }^{\circ} \mathrm{F}\right)$, which can be converted to degrees Celsius $\left({ }^{\circ} \mathrm{C}\right)$ by using the following equation:

$$
{ }^{\circ} \mathrm{C}=\left({ }^{\circ} \mathrm{F}-32\right) / 1.8
$$

Vertical coordinates: Vertical coordinates in this report are referenced to the North American Vertical Datum of 1988 (NAVD 88).

Horizontal coordinates: Unless otherwise specified, horizontal (latitude and longitude) coordinates in this report are referenced to the North American Datum of 1983 (NAD 83).

Acronyms and abbreviations:

$\begin{array}{ll}\text { CMI } & \text { Crop Moisture Index } \\ \text { DM } & \text { Drought Monitor } \\ \text { ENSO } & \text { El Niño-Southern Oscillation } \\ \text { FEMA } & \text { Federal Emergency Management Agency } \\ \text { GIS } & \text { geographic information system } \\ \text { NAD 27 } & \text { North American Datum of 1927 } \\ \text { NAD 83 } & \text { North American Datum of 1983 } \\ \text { NAVD 88 } & \text { North American Vertical Datum of 1988 } \\ \text { NCDMAC } & \text { North Carolina Drought Management Advisory Council } \\ \text { NCDMC } & \text { North Carolina Drought Monitoring Council } \\ \text { NCDWR } & \text { North Carolina Division of Water Resources } \\ \text { NDMC } & \text { National Drought Mitigation Center } \\ \text { NOAA } & \text { National Oceanic and Atmospheric Administration } \\ \text { OSW } & \text { Office of Surface Water } \\ \text { PDSI } & \text { Palmer Drought Severity Index } \\ \text { PHDI } & \text { Palmer Hydrological Drought Index } \\ \text { SPI } & \text { Standardized Precipitation Index } \\ \text { USGS } & \text { U.S. Geological Survey } \\ \geq & \text { greater than or equal to } \\ < & \text { less than }\end{array}$




\title{
The Drought of 1998-2002 in North Carolina - Precipitation and Hydrologic Conditions
}

\author{
By J. Curtis Weaver
}

\section{Abstract}

$\mathrm{D}$ rought conditions prevailed across much of North Carolina during 1998-2002, resulting in widespread record-low streamflow and ground-water levels in many areas. During this 4-year period, the drought was continuous in areas of western North Carolina, although eastern areas of the State had some periods of relief from tropical storms in 1998 and 1999. The occurrence of dry winters in 2001 and 2002 along with a dry spring in 2002, exacerbated drought conditions across the State and resulted in substantial declines in streamflow and ground-water levels during the summer of 2002.

The drought caused widespread hardship and economic losses across North Carolina. During the latter months of 2002, more than 200 municipalities that included most major cities operated under some form of voluntary, mandatory, or emergency water conservation. Reservoirs across North Carolina were at record or near record-low levels, including some of the largest ones used for multiple purposes (flood control, low-flow augmentation, and(or) recreation), and required continuous and careful operation to balance the upstream and downstream needs of users.

Precipitation deficits during the 1998-2002 drought for some locations in North Carolina were among the largest documented since the beginning of systematic collection of weather data. The largest deficits occurred primarily in the western Piedmont and were as much as 60 to 70 inches in some locations during the 4-year period. Cumulative monthly precipitation departures for the period May 1998 through September 2002 at 13 selected precipitation sites across the State ranged from 5.3 inches below normal in Greenville (eastern North Carolina) to 66.7 inches below normal in Hickory (western North Carolina). During the 12-month period October 2002 through September 2003, precipitation departures at 7 of the 13 sites were more than 20 inches above normal, primarily in the western Piedmont. Precipitation data for the period of record were examined for 8 of the 13 sites to compare precipitation deficits during the 1998-2002 drought with those that occurred during selected historical droughts. At three of the eight sites (Hickory, Charlotte, and Mocksville), the average monthly deficit for the 1998-2002 drought exceeded the values computed for the other drought periods. Precipitation records for three other sites (Greensboro, Raleigh, and Fayetteville) were adjusted to remove monthly rainfall values associated with several large tropical storms in 1999. The average monthly deficits for the 1998-2002 drought based on adjusted records for these three sites were then determined to be the highest among the drought periods identified during the available periods of precipitation record.

Daily mean discharges before and after the drought were compiled for 211 continuous-record gaging stations operated in North Carolina in 2002. Of these 211, 150 stations had periods of record that exceeded 10 years. Among these 150 sites, records of lowest daily mean discharge were set at 65 sites during the 4-year drought (55 sites during the 2002 water year alone). A smaller group of
68 sites having 30 years of uninterrupted record through the 2002 water year and not known to be significantly affected by regulation and(or) diversions was selected for further analyses to quantify the "daily" percentile and recurrence intervals of 7-day average discharges.

Comparisons of minimum 7-day average discharges at six selected gaging stations with long-term records (two from each physiographic province in the State) provided insight into how the 1998-2002 drought compares with previous droughts. At three of the six sites, all located in the Blue Ridge and Piedmont Provinces, the minimum 7-day average discharges during the 19982002 drought became the minimum flows of record. One of these three sites, the French Broad River at Asheville, has the longest period of discharge records in North Carolina. These comparisons confirmed that the deepest effects of the 1998-2002 drought occurred in streams in the Blue Ridge and western Piedmont Physiographic Provinces of North Carolina.

Ground-water levels were recorded in 137 observation wells in North Carolina in 2002. The water-level data from 96 of these wells were used to monitor the effects of human-induced stresses (namely, ground-water withdrawals) and in 41 wells to monitor changes in ground-water storage in response to climate changes. Examination of the ground-water data at sites having at least 5 years of record through the 2002 water year indicates that new record-low water levels for the periods of record were set at 45 of these wells during the 2002 water year alone. 
Examination of ground-water records collected by the U.S. Geological Survey and the North Carolina Division of Water Resources resulted in the selection of 21 climate-response wells that were spatially distributed across the State. Record-low water levels were recorded in 13 of these wells during the 1998-2002 water years; record-low levels were set at 11 of the 13 wells during the 2002 water year alone. For the 13 wells in which new record-low water levels were recorded, the difference between the pre-drought water levels and new record-low water levels ranged from 0.05 to 2.85 feet.

Cumulative monthly departures in precipitation, streamflow, and ground-water data were plotted for five pairs of selected surface-water and ground-water monitoring sites in close proximity to each other to compare the time lags associated with the onset of drought conditions in mid-1998 and the drought recovery that began in late 2002. In particular, comparisons of these plots provided some insight into the rapid reversal in hydrologic conditions following above-normal rainfalls that began in August and September 2002. Comparisons of cumulative monthly departures in discharge at two surfacewater sites (South Yadkin River and French Broad River) in western North Carolina also indicated that drought recovery was rapid compared with the recovery periods following historical droughts.

\section{Introduction}

D rought conditions prevailed across much of North

Carolina during 1998-2002, resulting in widespread record-low streamflow and ground-water levels in many areas of the State. Drought conditions initially occurred in the western part of the State, affecting streams in the Blue Ridge and western Piedmont Physiographic Provinces (fig. 1). In the eastern Piedmont and Coastal Plain, drought conditions generally were less widespread through about mid 2000.
Late-summer tropical storms prevented the continuous, widespread drought conditions in eastern North Carolina that were observed in the western part of the State. Beginning in late 2000, however, widespread drought conditions began to spread across much of the State and continued until late summer 2002 when above-normal rainfall occurred in many areas of the State. In terms of streamflow and ground-water levels, the lowest conditions occurred during summer 2002. Dry winters in 2001 and 2002 along with a very dry spring in 2002 contributed to the extremely low hydrologic conditions that were observed during the summer. While numerous record-low streamflow and ground-water levels for periods of record were established at gaging stations and observation wells across the State during the 1998-2002 water years ${ }^{1}$, most were set during the 2002 water year.

${ }^{1}$ Water year is the period from October 1 through September 30 and is identified by the year in which the period ends. The 2002 water year began on October 1, 2001, and ended on September 30, 2002.

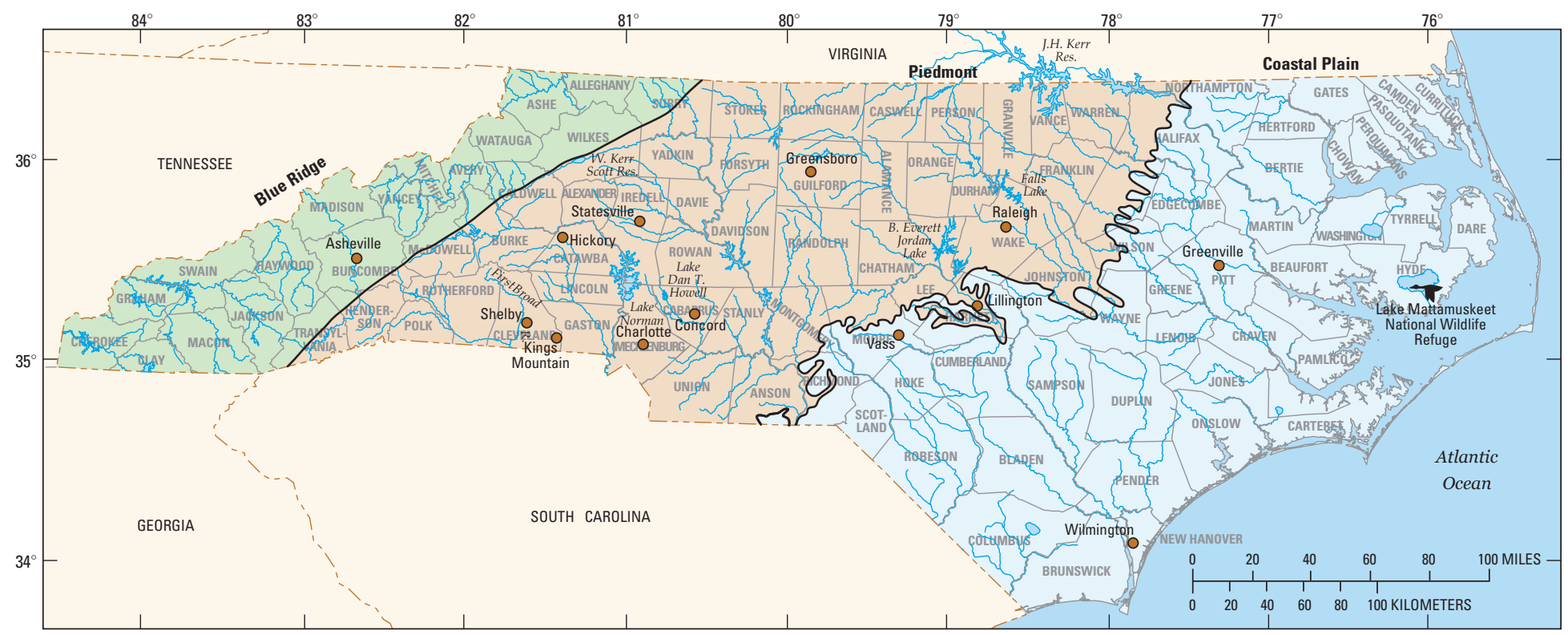

Figure 1. Locations of selected features and the physiographic provinces in North Carolina. 
While previous droughts of longer duration have occurred in North Carolina, the effects of the 1998-2002 drought are regarded as the most intense to date, causing severe stresses on public watersupply systems across the State. At the height of the drought, nearly 250 municipalities were operating under some form of water conservation. In general, the water-supply systems most affected were those that relied on river intakes and(or) those having small water-supply storage volumes. Water supplies in some systems decreased to levels representing only weeks of remaining supply. The drought also had adverse effects on agricultural production and recreational use of lakes and reservoirs. In the latter stages of the drought, many municipalities had decreased revenues resulting from lower sales of water to residential and business customers in compliance with water-conservation requirements. In some areas, industries incurred significant costs associated with declines in production and(or) efforts to adapt manufacturing operations to reduced water usage.

In concept, a drought is defined as a naturally occurring precipitation deficit during an extended period of time that adversely affects hydrologic conditions (Langbein and Iseri, 1960). However, the recognition of a drought generally is not based solely on measurement of precipitation deficits or below-normal hydrologic conditions. Droughts can occur over a period of a few months or even years and often are characterized by their effects on activities or operations that are regarded by the general public as important in maintaining quality of life and sustaining economic viability. Because droughts are subtle in the initial stages and may have multiple stages and evolving levels of severity, operational definitions of drought have been established to better characterize the start, severity, and end of a drought (National Drought Mitigation Center, 2003c; see "Different Types of Droughts"). In general, much of the public typically does not recognize the presence of a drought until it is well established and begins to affect them
A drought is defined as a prolonged deficiency in precipitation that adversely affects hydrologic conditions.

in some way, primarily through waterconservation requirements.

Because droughts affect hydrologic conditions in varying degrees across regional areas, it is helpful to have access to data that describe current streamflow and ground-water levels. Historical percentiles and other statistical analyses can be developed to characterize and compare observed conditions. Data collected at U.S. Geological Survey (USGS) streamgaging stations having long-term periods of record with little or no known regulation or diversions and at USGS groundwater observation wells unaffected by pumping provide a means of monitoring changes in hydrologic conditions in response to climatic changes. Unlike floods, which typically pass in a matter of days or weeks, droughts can persist much longer and must be reassessed on a regular basis to provide information for use by State and local water-resource managers to continuously monitor and maintain adequate water supplies. Therefore, hydrologic information from the USGS must be available in a format and context that allow timely, effective, "on-demand" assessment of streamflow and ground-water conditions (see "USGS WaterWatch: Providing
Real-Time Streamflow Characterization on the Internet").

Following the experiences of a drought across North Carolina in the mid- and late 1980s, tracking droughts and their effects became a concern for several State and Federal agencies. Beginning in the early 1990s, the agencies met as needed on an informal basis to assess drought conditions, particularly those occurring in 1993 in parts of the State. In April 1994, an emergency operations plan for droughts was developed by the North Carolina Division of Emergency Management, and the North Carolina Drought Monitoring Council (NCDMC) was formally recognized as the primary working group charged with guiding assessment and response processes during droughts. The NCDMC is a consortium of State and Federal agencies, including the USGS. The North Carolina Division of Water Resources (NCDWR) is the lead agency for the council and provides the chairperson. During the mid-1990s, the NCDMC generally met once or twice a year, primarily during early summer, to assess conditions and discuss climatic outlooks for the upcoming period.

With the onset of drought conditions in western North Carolina in mid-1998, the NCDMC began holding monthly meetings to monitor and assess the drought. The monthly meetings continued until early 2003 when abovenormal rainfalls improved hydrologic conditions to the point where drought

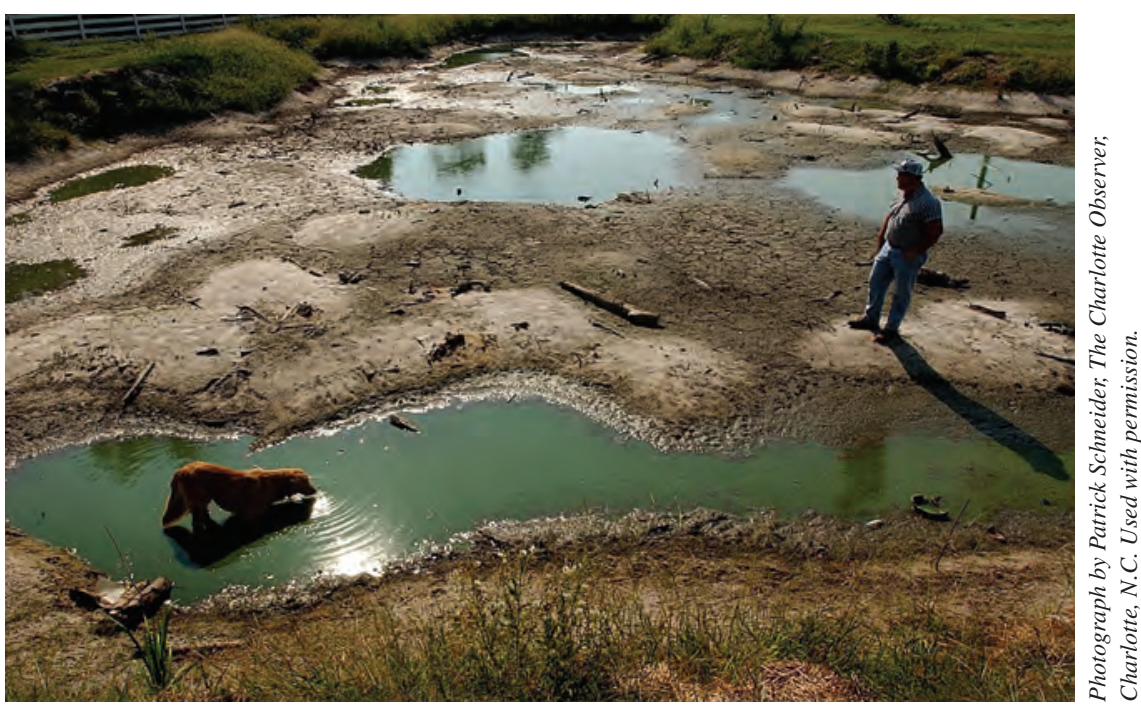

A farmer surveys the remains of a dried out watering pond on his farm in Manning, S.C., July 26, 2002. 


\section{Different Types of Droughts}

A drought is defined as a prolonged deficiency in precipitation that causes adverse effects to the environment or economy. Because droughts have differing effects, four operational definitions of drought are used to assess the beginning, end, and general severity of a drought (National Drought Mitigation Center, 2003c). These four definitions of droughts are meteorological, agricultural, hydrological, and socioeconomic. These definitions do not imply that only one kind of drought can occur at any given time; it generally is common during the progression of drought conditions that more than one type of drought occurs simultaneously.

A meterorological drought is considered the simplest type of drought and typically is regarded as the first stage of a long-term drought. This type of drought typically is noticed by meteorologists or farmers within a few weeks when little or no precipitation has occurred, generally resulting in no significant effects. Because such a drought is characterized solely by measures of precipitation, a meteorological drought can begin and end very quickly with a change in weather patterns (Heim, 2002). A meteorological drought is measured by some degree of deviation from normal precipitation (for example, the number of days during
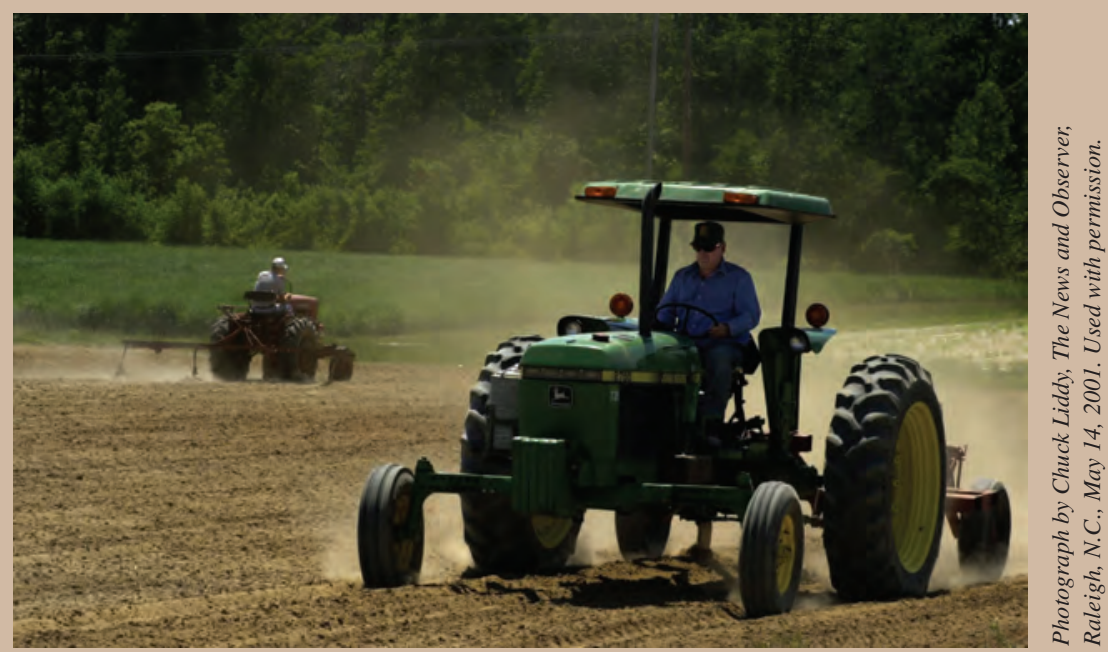

Preparing soil for planting sweet potatoes at the North Carolina State University Agricultural Research Service property on the Wake-Johnston County line. Lack of rain delayed the planting of soy beans. which only a certain percentage of precipitation has occurred). Such measures are very specific from region to region and are, therefore, limited in usefulness across large areas of a state or country (National Drought Mitigation Center, 2003c). For example, below-normal rainfall amounts along the eastern seaboard would likely be considered above normal in arid regions of the southwestern United States.

An agricultural drought is characterized by the various needs for water by plants and crops, which typically are the first effects noted in a prolonged drought. An agricultural drought reflects a lack of water in the top soil layers where roots extend into the ground and is not characterized by the presence or absence of water in the deeper layers (Heim, 2002). Thus, agriculture is the first economic sector to be affected by the occurrence of a drought. Not only do water needs vary among crops, but also among stages of growth. Thus, the presence of sufficient water during the germination stage may overcome the effects of drought during the latter stages of growth. Beyond a measure of precipitation deficits, an agricultural drought also reflects the differences between precipitation amounts and evaporation (National Drought Mitigation Center, 2003c). An agricultural drought is, therefore, the result of several factors that combine to affect water availability for plant and crop growth, leading to the recognition that droughts do not occur simply as a result of below-normal rainfall patterns.

When below-normal precipitation continues for an extended period of time, streamflow and ground-water levels decline because of declining water in the subsurface layers (Heim, 2002). Such conditions are defined as a hydrological drought because the water table declines to levels that affect well yields and limit sustained base flows to streams. A hydrological drought also is characterized by smaller water volumes in reservoirs and lakes. The effects of hydrological droughts are water-supply related and generally affect larger populations of people because of water-conservation mandates by governing bodies responsible for ensuring adequate water supplies. Lower streamflows during hydrological droughts also affect recreational and navigational uses of water. Changes in streamflow and groundwater levels often lag behind changes in precipitation by several months, both in the beginning and ending stages of a drought (National Drought Mitigation Center, 2003c). Because hydrologic systems extend across various climatic regions, it is possible for a meteorological drought in one region to cause a hydrological drought in a nearby region where precipitation has not been deficient.

The fourth type of drought is a socioeconomic drought, resulting in conditions that adversely affect the demand and supply of economic goods and services (National Drought Mitigation Center, 2003c). A socioeconomic drought can affect the abilities of manufacturing and(or) industrial sectors to deliver products because of watersupply shortages. The 1998-2002 drought in North Carolina was primarily a hydrological drought across most areas. However, some of the drought's effects were characteristic of a socioeconomic drought, resulting in mandatory water-conservation requirements in some areas of western North Carolina that stressed the productive capabilities of some industries. Increased costs were incurred in efforts to adapt operations to smaller water-use volumes or to accommodate 


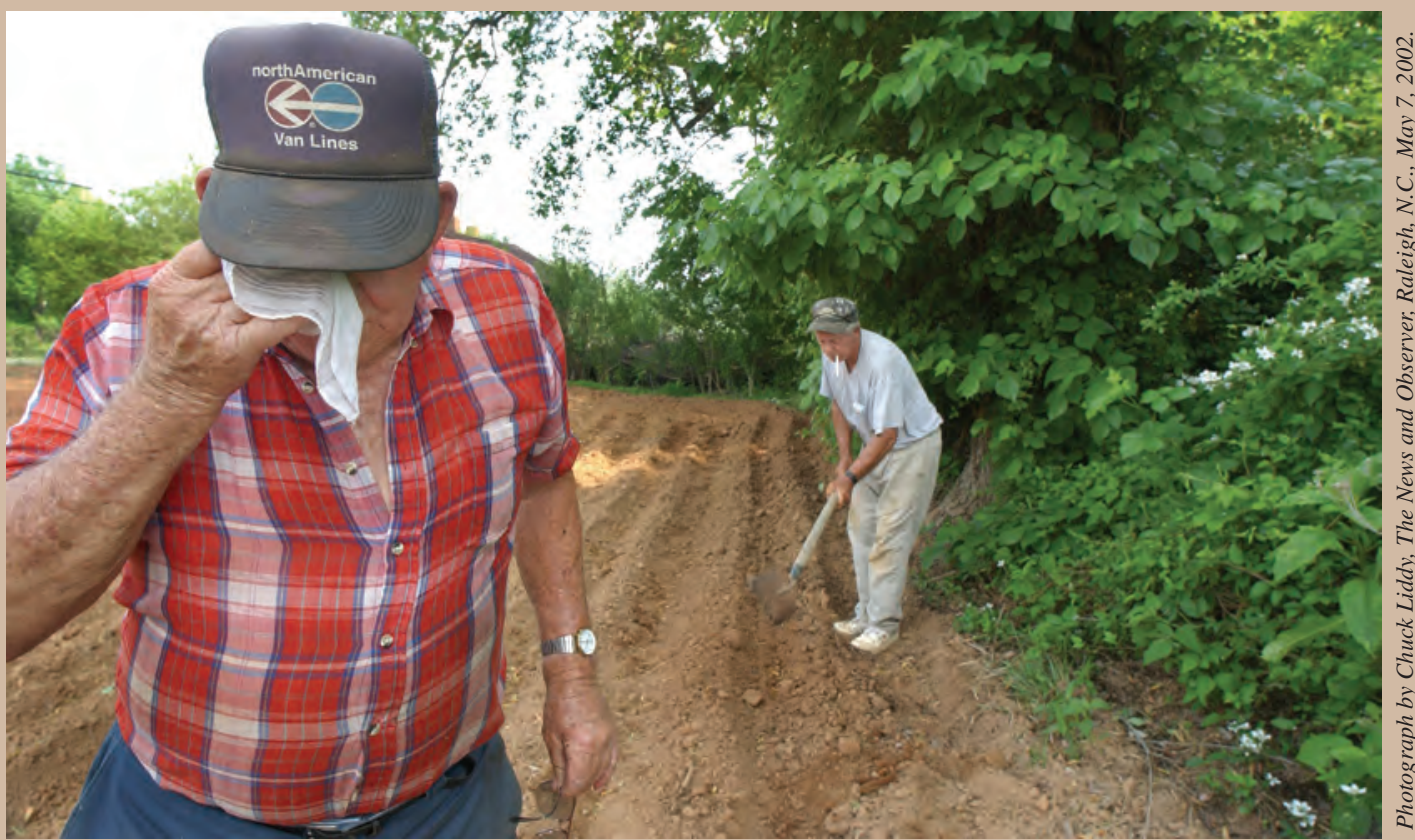

"I've seen worse, but this is the worst it's been in years and years," said Raymond Andrews of Bahama, N.C., shown here with his friend Earle Earnest tending their dry garden. Andrews has more than 50 years of farming experience. more types of droughts to occur simultaneously and sometimes in unexpected combinations. In 2001, a hydrological drought was entrenched across most areas of North Carolina, but the agricultural drought that year was minimal because of timely rainfalls that occurred during the summer at various stages of crop development. Thus, while rainfall was not sufficient to raise streamflow and ground-water levels, it was sufficient to provide moisture to the top soil layers, thereby minimizing crop losses during the growing season. Because of the time lags between precipitation and improved hydrologic conditions, it is common for a meteorological drought to end, while a hydrological drought continues. Above-normal rainfalls began to occur in August and September 2002 across most of North Carolina. However, the streamflows and ground-water levels did not begin to increase for several months. In spring 2003 , hydrologic conditions in most areas had reached sustained normal conditions, thereby ending the hydrological drought.

2002d). Water-use conservation measures in one Piedmont community went as far as requesting businesses to use portable toilets (News and Observer Publishing Company, 2002b). In some of the most stressed regions, disposable paper products were used in restaurants for serving food instead of china and utensils, thereby reducing water use for cleaning and sanitation tasks (News and Observer Publishing Company, 2001, 2002b).

Despite various levels of stress brought upon the general public in North Carolina as a result of the 1998-2002 drought, the greatest stress for most of the population seemed to be compliance with the water-reduction measures necessary to help conserve public water supplies. In North Carolina, and throughout most of the United States, a combination of a strong infrastructure and engineering resources (for example, interconnected water-supply systems) usually helps to minimize the effects of a severe socioeconomic drought. In contrast, the effects of a socioeconomic drought are more severe in less-developed countries. For example, a socioeconomic

drought in a less-developed country can disrupt the food supply causing widespread migration of the population and severe malnutrition and disease.

Although the four different types of drought generally occur in the sequence described above, it is possible for one or

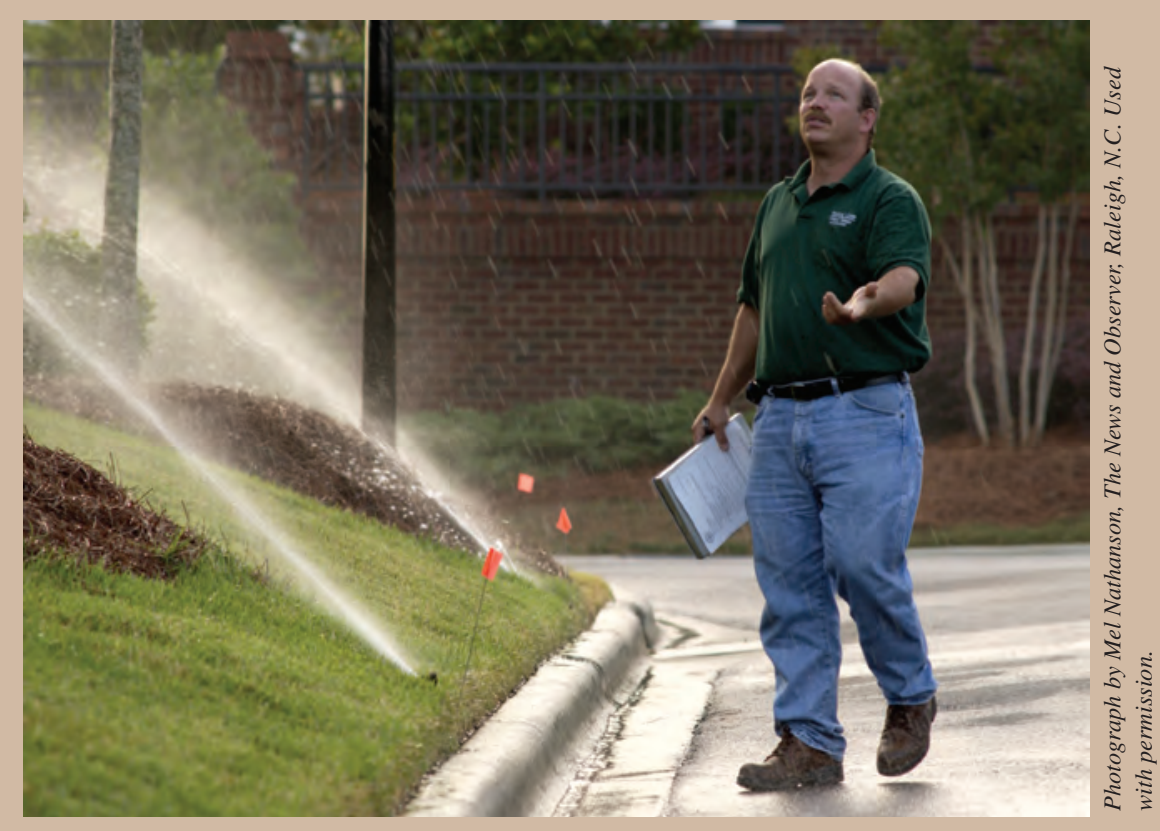

A water conservation technician inspects an out-of-compliance sprinkler system in Cary, N.C., June 28,2002 
conditions were considered nonexistent. In addition to monthly meetings, the NCDMC sponsored or participated in workshops and special meetings throughout the State to increase awareness of drought conditions among

At the height of the 1998-2002 drought, nearly 250 municipalities in the State were operating under some form of water conservation.

water-supply managers, public officials, and the media (September 1998 in Asheville, November 2000 in Mooresville, July 2002 in Raleigh, August 2002 in Greensboro, and September 2002 in Concord). In 2003, the General Assembly of North Carolina gave statutory recognition to the council and changed its name to the North Carolina Drought Management Advisory Council (NCDMAC, used hereafter in this report). While the purpose and function of the NCDMAC remain generally unchanged, recognition by the General Assembly is a reflection of the significance of the 1998-2002 drought and a strong awareness of the need for a central organization to issue coordinated advisories and to assist with response processes during future droughts.

The effects of droughts and the ability of governments and businesses to prepare and respond to droughts also has been the recent focus of a nationally appointed group representing various interests and agencies across the United States. In July 1998, Congress passed the National Drought Policy Act of 1998, which established a commission of 16 members to investigate the role and coordination of Federal agencies in drought response. In May 2000, the commission released its findings and recommendations, which became the foundation of the National Drought Preparedness Act of 2002, later revised and renamed the National Drought Preparedness Act of 2003 (Western Governors' Association, 2004). Key objectives of the act are to (1) create a national policy to promote drought response that is less costly and reactive in its approach and more proactive and prepared; (2) establish the National Drought Council to coordinate and integrate Federal drought programs; (3) assist states, local governments, tribes, and other entities in the development and implementation of drought preparedness plans; and (4) facilitate the development of the National Integrated Drought Information System to improve the characterization of current droughts, the forecasting of future droughts, and to provide the recognition needed for Federal drought assistance. The legislation for this act was still pending in spring 2005 (Mr. Shaun McGrath, Western Governors' Association, written commun., March 14, 2005).

\section{Purpose and Scope}

This report describes the 1998-2002 drought in North Carolina in terms of precipitation patterns and hydrologic conditions. The report also documents some of the effects of the drought on the citizens and economy of North Carolina and presents additional information about droughts in general.

Precipitation amounts are presented in terms of departures from normal for the water years and total deficits for the drought period. Streamflows that occurred during the drought are described in the context of historical percentiles and frequency (recurrence intervals) of 7-day average flows computed for each calendar date at numerous gaging stations. Ground-water conditions are presented in comparison with historical percentiles and record maximum and minimum values. Historical precipitation and hydrologic (streamflow, ground water) data available through September 2003 were used to characterize the full drought period of May 1998 through September 2002 and the recovery, which began in September 2002 and was considered complete by May 2003.

\section{Acknowledgments}

Precipitation data from National Oceanic and Atmospheric Administration (NOAA) stations across North
Carolina and maps of precipitation distributions during the drought were provided by Ryan Boyles of the North Carolina State Climate Office at North Carolina State University. In addition, Mr. Boyles' insight and understanding of droughts and other climate-related issues in North Carolina was valuable in the development of the sidebar articles included in this report to provide general drought information.

Information concerning the overall drought effects was provided by Woody Yonts and other members of the NCDMAC. Mr. Yonts, who chairs the Council and represents the North Carolina Division of Water Resources on the Council, provided valuable information about the effects of the drought.

The author also wishes to acknowledge the National Drought Mitigation Center (NDMC), established in 1995 at the University of Nebraska at Lincoln. The Center promotes improved understanding of droughts and the accompanying effects of such events. Online information developed by the NDMC staff proved to be extremely useful in the preparation of this report.

Individuals from the USGS who contributed to the development of this report include Harry Lins, Drought Coordinator in the USGS Office of Surface Water (OSW), which provided support for this report. Mr. Lins also was the motivating force behind the development of the USGS WaterWatch Internet pages that quickly became the means of assessing "real-time" streamflow conditions during the 1998-2002 drought. Timothy Spruill, Melinda Chapman, and Douglas Smith of the USGS North Carolina Water Science Center provided technical guidance concerning the ground-water analyses for this report. Beth Wrege compiled much of the information used to document the societal effects of the 1998-2002 drought in North Carolina, and Jerad Bales and Jeanne Robbins provided both technical and nontechnical guidance in developing the report. 


\section{USGS WaterWatch: Providing Real-Time Streamflow Characterization on the Internet}

During the 1998-2002 drought, the USGS made significant strides in the delivery of streamflow information on the Internet. While real-time streamflow data for individual sites were available by the mid-1990s, no means was available for a quick and simple characterization of streamflow data in the context of historical statistics. That is, while one could easily determine current streamflow conditions for many sites in the United States, this information could not be compared with historical records without assessing streamflow data for each individual site, one at a time.

In mid-1999, a new tool to enable such flow characterizations was designed by constructing a geographic information system (GIS) map of streamflow index values at sites having long-term records (greater than 30 years). The map quickly became the centerpiece of the "WaterWatch" pages that USGS personnel and outside interests began using to monitor the extent and severity of drought conditions occurring across the eastern United States.

A streamflow index value, ranging from 1 to 7 , for each streamflow-gaging station is determined by first computing the percentile ranking of the site's current streamflow, using historical daily streamflows either for a specific date or for the period of record (fig. A-1). The computed percentile will then fall into one of the seven categories of arbitrarily assigned percentile ranges known as streamflow index values and denoted by a specific color. Each site is then plotted as a color-coded circle on a map that is continuously updated as real-time information is received by satellite transmission from the streamflow-gaging stations. This presentation allows users to view the spatial distribution and variation in streamflow across the United States or across a specific state. In addition to comparing real-time streamflows, maps available on the USGS WaterWatch Internet pages also compare daily mean streamflow and 7-day average flow with ranges of historical data for a specific day or week of the year (fig. A-1).

The key to the success of the WaterWatch pages is the use of percentiles computed from historical data to make comparisons with current streamflow conditions. For many people, percentiles are relatively easy statistics to understand because of their widespread use in nonhydrologic settings (for example, academic scores, medical information). Seven categories of percentiles are used to convey the current streamflow conditions: (1) new minimum for calendar date; (2) less than 10th percentile, very dry conditions; (3) 10th-24th percentiles, dry conditions; (4) 25th-75th percentiles, normal range of flow; (5) 76th-90th percentiles, wet
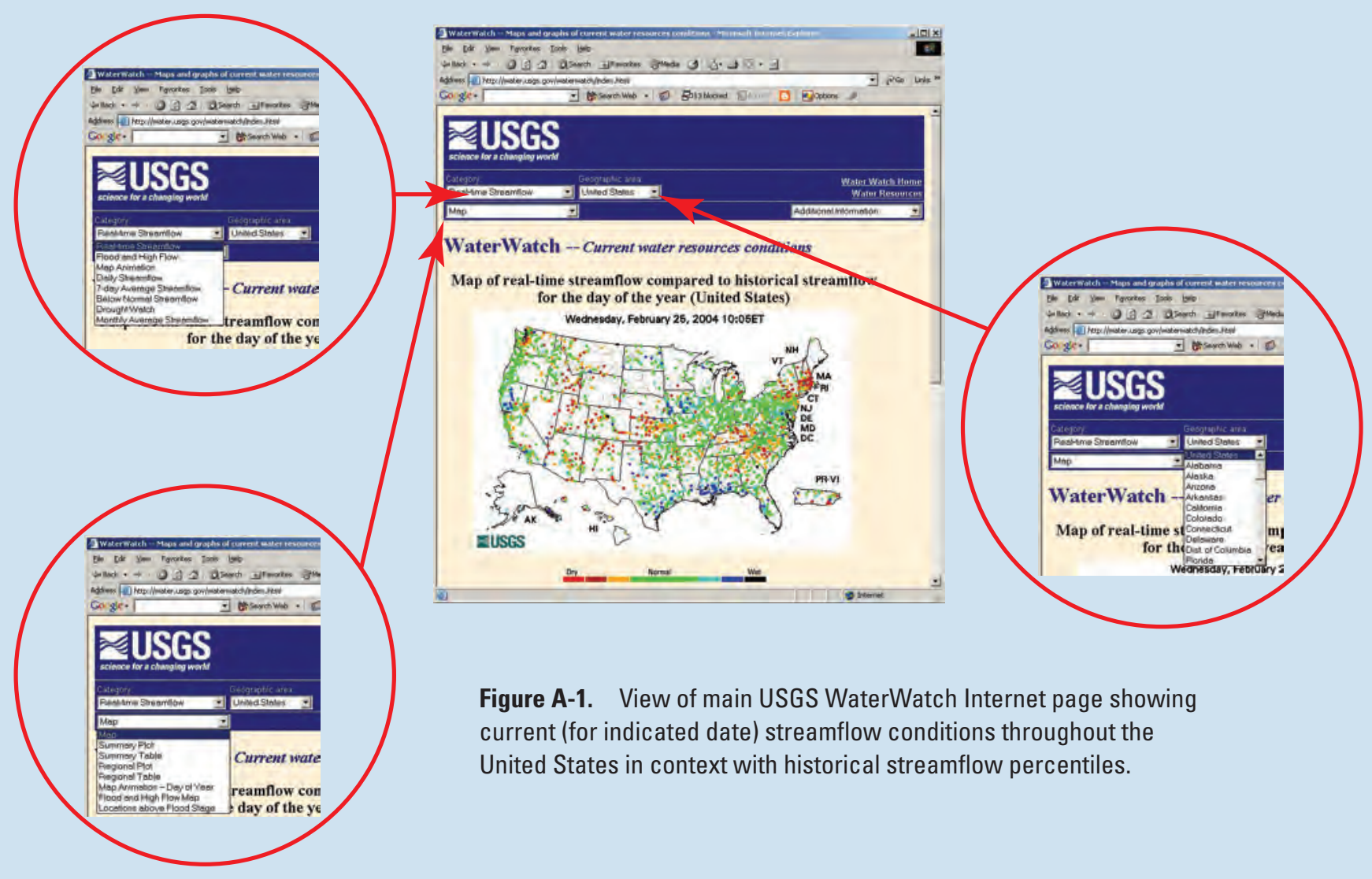

Figure A-1. View of main USGS WaterWatch Internet page showing current (for indicated date) streamflow conditions throughout the United States in context with historical streamflow percentiles. 
conditions; (6) greater than 90th percentile, very wet conditions; and (7) new maximum for the calendar date. The occurrence of below-normal flows (less than 25th percentile) for a given site do not necessarily mean that drought conditions are in effect, because changes in flows also occur as a result of human-induced changes. Nevertheless, the occurrence of belownormal flow conditions for many sites in a given region on a daily basis suggests the presence of a hydrological drought. During the 1998-2002 drought, many sites in North Carolina were consistently in the below-normal ranges, as indicated by the abundance of colors ranging from orange (10th-24th) to bright red (new minimum; fig. A-2). These colors dominate the early August 2002 map when hydrologic conditions in North Carolina were at the lowest levels observed during the drought. However, in May 2003 when the last effects of the 1998-2002 drought were declared nonexistent, streamflow conditions were consistently in the 75th or higher percentile (fig. A-2).

Another advantage of the use of percentiles is the ability to compare current streamflow conditions to the full range of possible conditions. Even though the USGS WaterWatch maps were designed to help in assessing drought conditions, the maps also depict areas having high-flow conditions (greater than 75th percentile, shown in blue and black colors), as shown in the September 16, 1999, map where the general track of Hurricane Floyd (making landfall on September 16) is easily visible along the eastern seaboard (fig. A-3). The image depicts two extremes of flow conditions in North Carolina on that date-the record-setting high flows in the eastern half of the State and the drought conditions that remained in effect throughout much of the western half. Among the WaterWatch pages, a series of consecutive map images for each date are pieced together to create animations of streamflow conditions for each month, revealing the movement of storm systems across the United States.
CURRENT STREAMFLOW

(Tuesday August 06, 2002 07:20ET)
CURRENT STREAMFLOW

(Wednesday May 21, 2003 07:20ET)
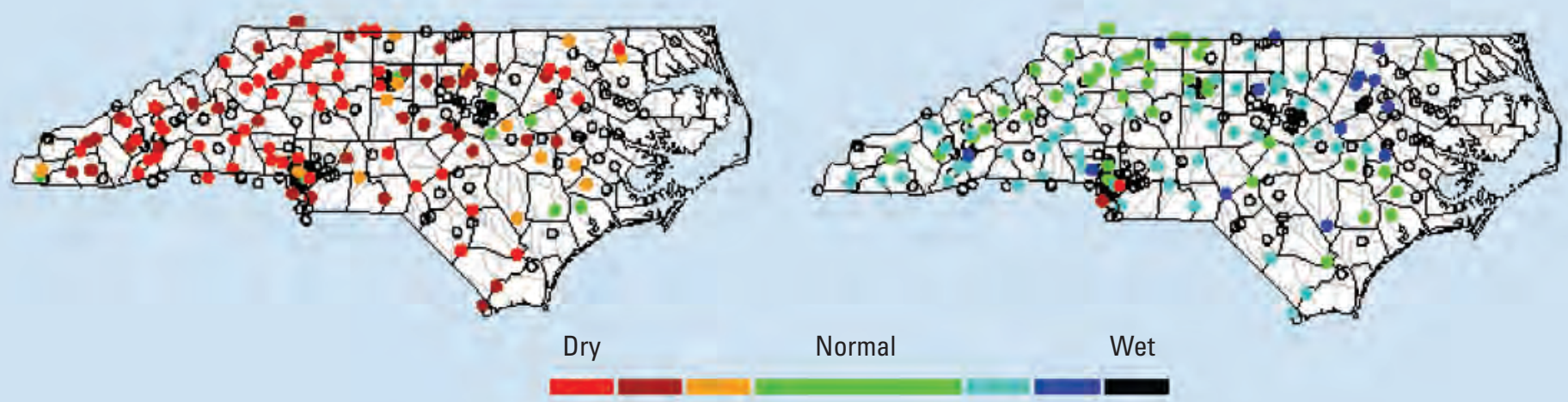

BELOW-NORMAL FLOW

(Monday August 05, 2002)

Note: Open circle indicates normal or above-normal flow conditions

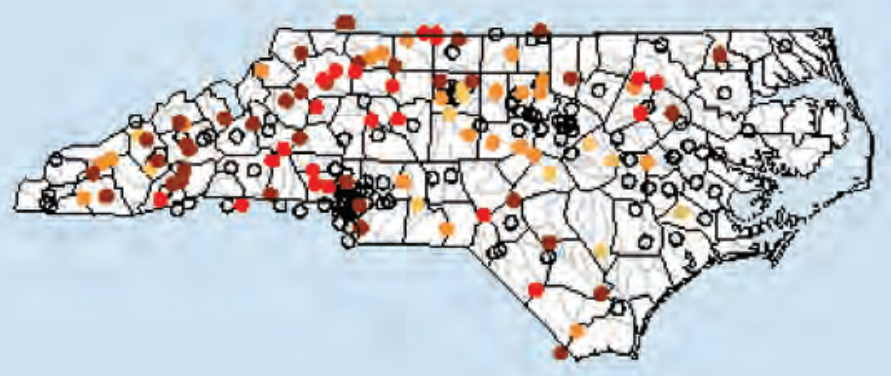

BELOW-NORMAL FLOW

(Monday May 19, 2003)

Note: Open circle indicates normal or above-normal flow conditions

Figure A-2. Streamflow conditions in North Carolina, as depicted by USGS WaterWatch, for selected dates in August 2002 and May 2003. 


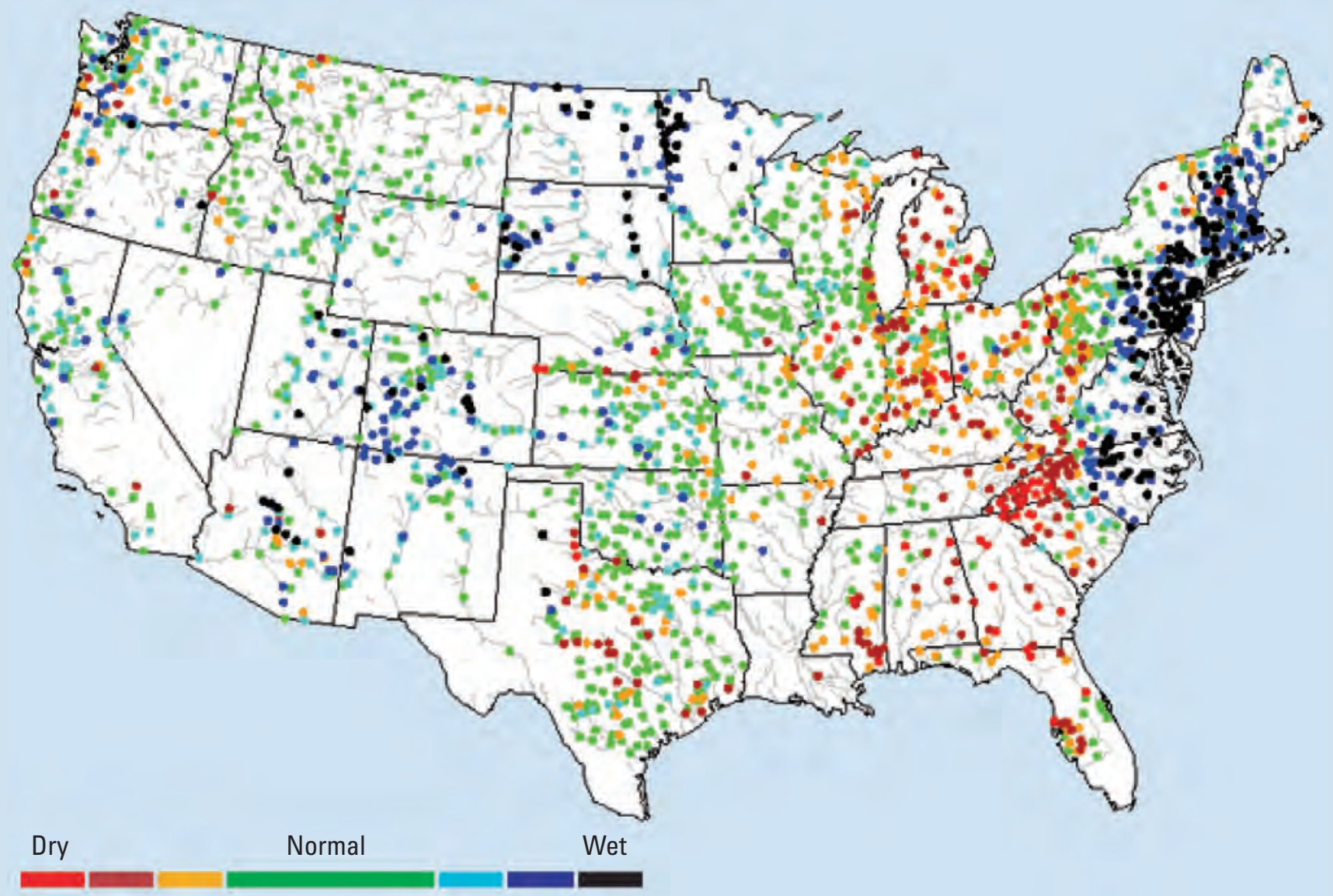

Figure A-3. Streamflow conditions across the United States, as depicted by USGS WaterWatch, on September 16, 1999. (Note the evidence of the landfall and movement of Hurricane Floyd along the eastern seaboard.)

The lake level at B. Everett Jordan Lake at the dam in Chatham County on August 15, 2002, was 210.2 feet, about 6 feet below the normal operating level. Lake levels further declined to about 209.9 feet in late August prior to the arrival of rainfall that eventually raised the lake level to spillway elevation in fall 2002.

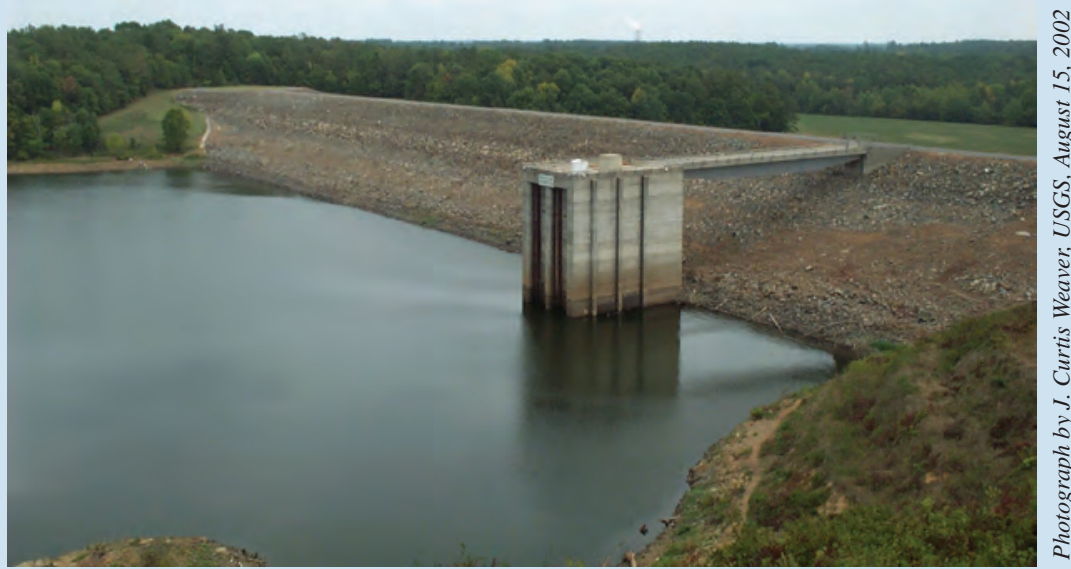




\section{Precipitation During the 1998-2002 Drought}

The hydrologic cycle is the movement of water between the atmosphere and the earth, with precipitation being the primary source of streamflow and ground water (fig. 2). The cycle is completed when water that evaporates from surficial water bodies into the atmosphere returns as precipitation. For all of North Carolina, rainfall is the primary form of precipitation.

When below-normal precipitation occurs for an extended period of time, the hydrologic cycle becomes disconnected in areas where less water is available to move through the hydrologic system (for example, low streamflows and ground-water levels). Continued precipitation deficits perpetuate the disconnected cycle because less soil moisture is available for evaporation; with less evaporation, fewer thunderstorms occur (Bosilovich and Schubert, 2001; Pal and Eltahir, 2001). Precipitation deficits that occurred during the 1998-2002 drought are discussed in this section. (For additional information on the climatic aspects of droughts, see

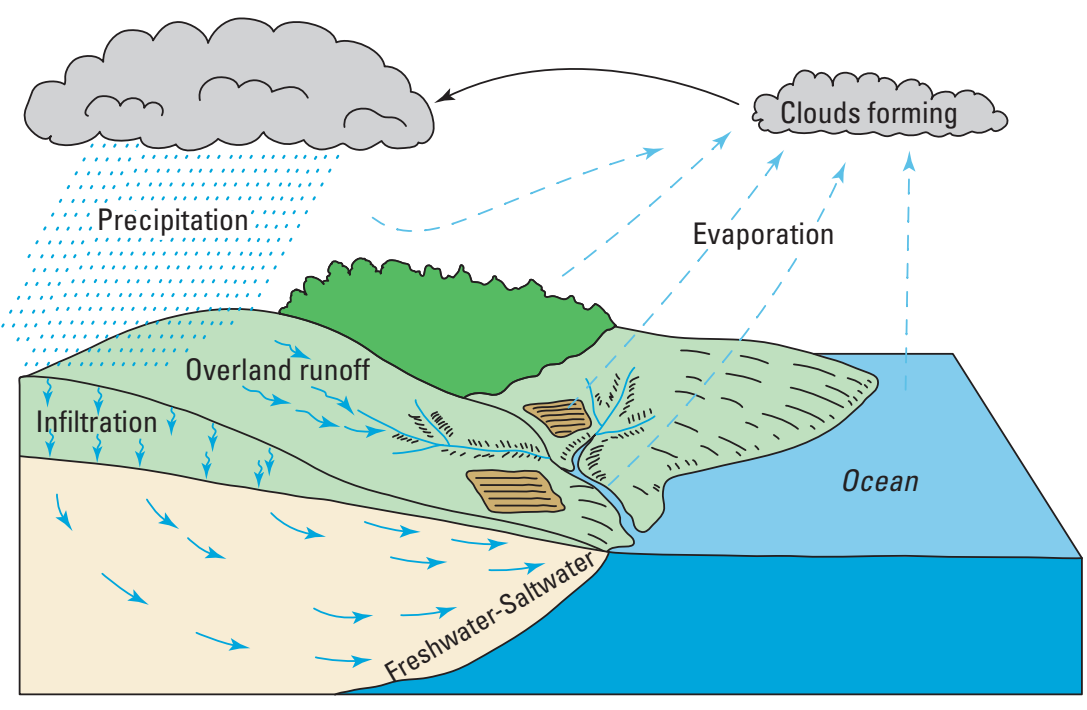

Figure 2. The hydrologic cycle depicts the movement of water through the hydrologic system (adapted from Heath, 1983).

"Climatic Causes of Droughts in North Carolina" and "Use of Drought Indices to Assess Droughts.")

Climate data in North Carolina are collected primarily by NOAA at more than 200 stations (State Climate Office of North Carolina, 2003). Precipitation data collected during the 1998-2003 water years at 13 selected stations across North Carolina (fig. 3) were used to analyze precipitation patterns during the drought. Using the 30-year (1971-2000) period of record as a reference, monthly rainfall departures, in inches, were the

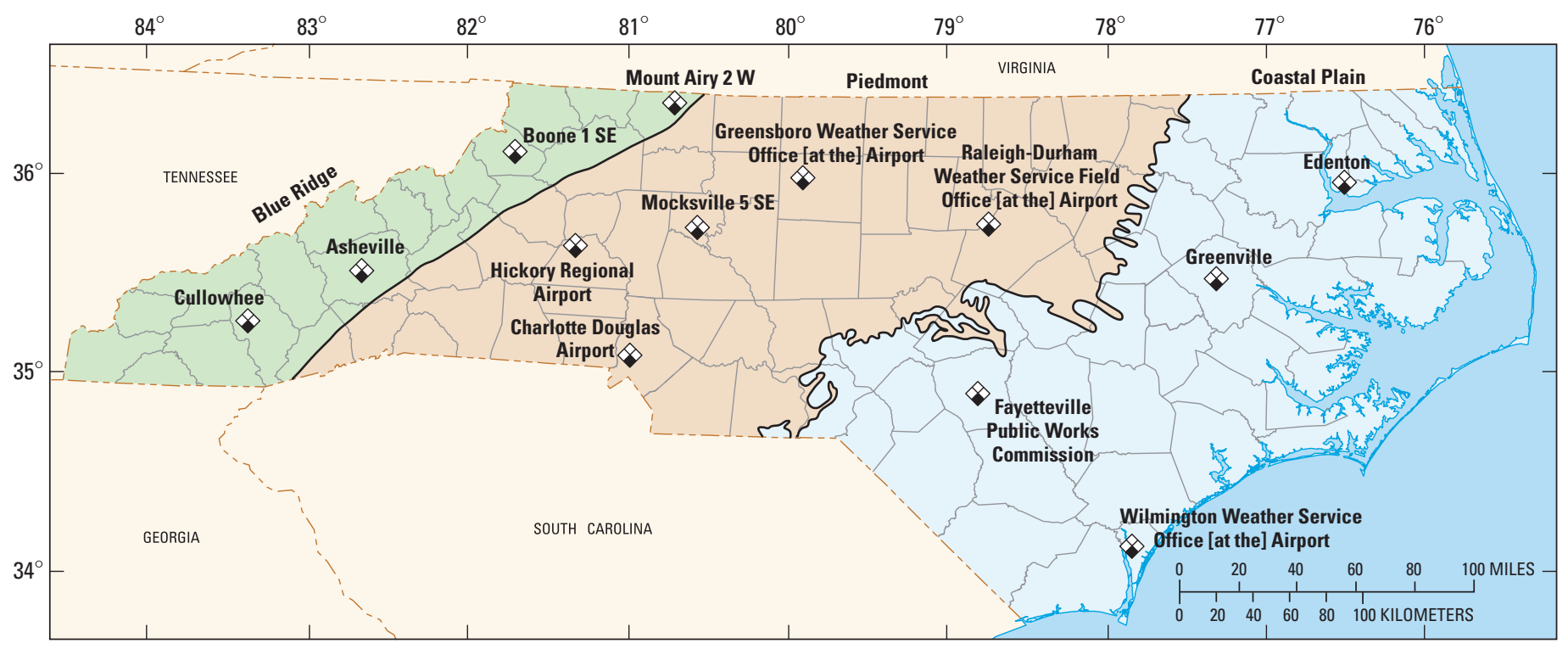

Figure 3. Selected National Oceanic and Atmospheric Administration precipitation stations in North Carolina, $1998-2003$. 


\section{Climatic Causes of Droughts in North Carolina}

While it is easy to understand that droughts occur because of prolonged deficiencies in precipitation, it is helpful to understand the underlying climatic causes of droughts. A drought usually is regarded as an abnormal, random event, but droughts are naturally recurring climatic phenomena (National Drought Mitigation Center, 2003c).

The humid subtropical climate of North Carolina consists of long, hot, humid summers and short, mild winters. The spring and autumn seasons provide the most pleasant weather and are the periods most favored by many of the State's residents. On average, annual precipitation across North Carolina ranges from about 38 inches to more than 80 inches (Daly and others, 1994, 1997; Spatial Climate Analysis Service, 2004), with the greatest variability occurring in the Blue Ridge Province (fig. B-1). Most of the State receives between 40 and 50 inches of precipitation annually. Eastern areas of the Coastal Plain receive between 50 and 55 inches, primarily because of sea-breeze effects and tropical storms that occur primarily in the late summer and early autumn. Areas of the State that receive the highest and lowest amounts of precipitation are, coincidentally, only about 50 miles apart. The highest precipitation amounts occur in the mountains of southwestern North Carolina where orographic effects result in enhanced precipitation amounts as storm systems traverse over the higher elevations. The lowest amounts of precipitation occur in the central mountains (near Asheville) where "rain shadow" effects from the surrounding mountains, particularly the large ridges to the southwest, apparently reduce the amount of precipitation reaching the area. Precipitation during the winter tends to be widely distributed, and many areas of the State can receive substantial amounts from a single storm system. Summer rainfall tends to be spotty, resulting from the convective patterns of daily heating and subsequent evaporation that aid in developing thunderstorms.

Under typical weather patterns, much of the moisture delivered to North Carolina comes from the Gulf of Mexico. With a

Bermuda high-pressure system that typically resides in the central North Atlantic Ocean, prevailing winds generally come from the south or southwest, thereby enabling the transport of moisture (Zembrzuski and others, 1991). Additionally, some storms move across the southern tier of the United States and turn northeastward along the eastern seaboard, delivering precipitation in a "wrap-around" effect. More common in the winter, these storms are sometimes referred to as "nor'easters" because of the cool and breezy conditions that accompany them. Some of the heaviest recorded snowfalls in

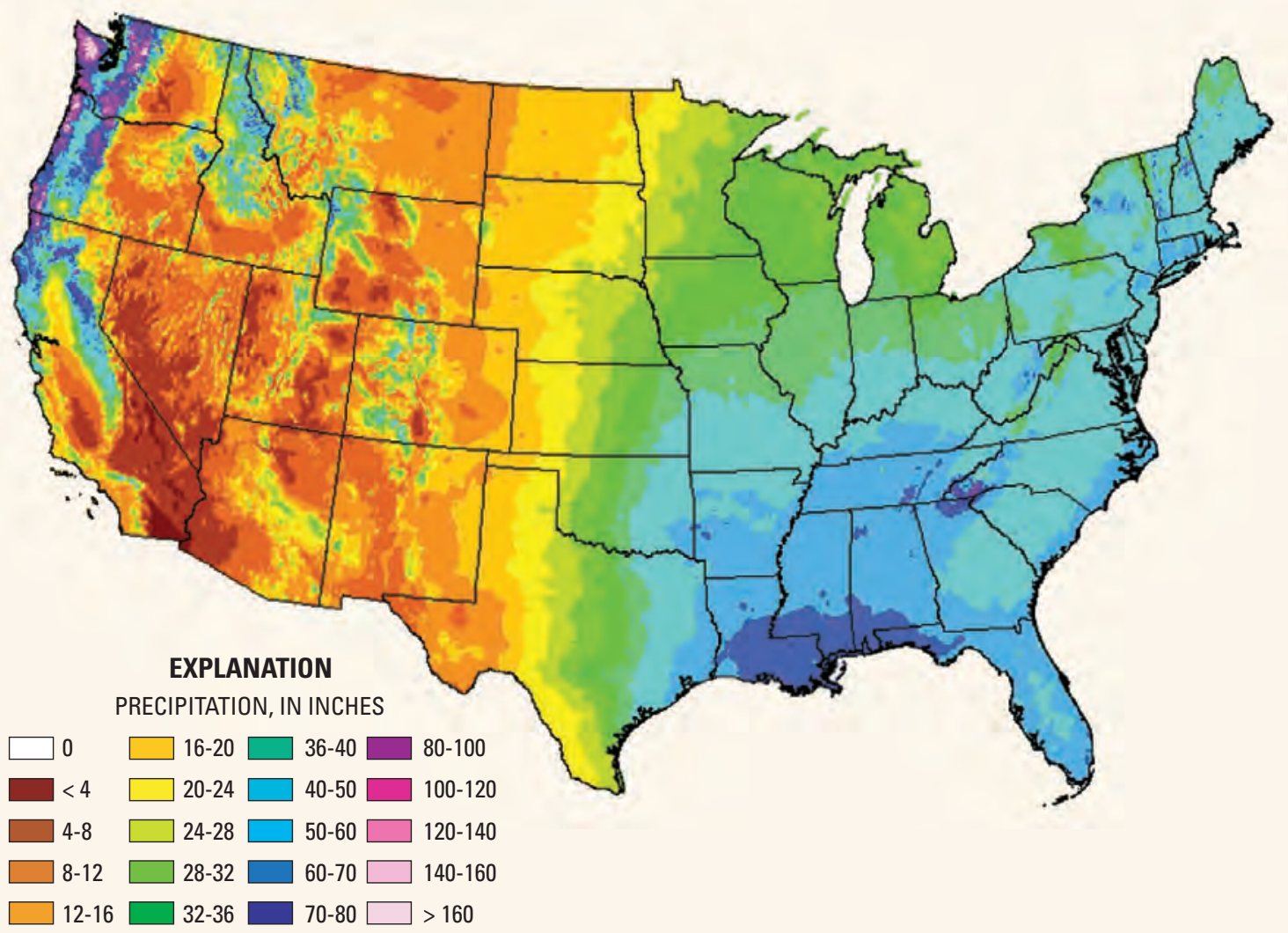

Figure B-1. Average annual precipitation in the United States (adapted from Daly and others, 1994, 1997; Spatial Climate Analysis Service, 2004). 
eastern North Carolina resulted from these coastal storms.

Droughts across the southeastern United States occur when Bermuda highpressure systems shift westward over the southeastern States and stall for an extended period of time. Because the western side of a high-pressure system brings prevailing south winds, a westward shift of the system transports moisture to the west toward the central United States. In addition, because a Bermuda high-pressure system extends vertically through the lower troposphere, the system's center results in a large-scale sinking flow of air that aids in warming the air mass (Zembrzuski and others, 1991). A mixed layer near the Earth's surface is capped by a warm, stable air mass that precludes the development of thunderstorms. During the summer, a lack of soil moisture can enhance overall drought conditions because little or no water is available for evaporation to aid in the development of thunderstorms (Bosilovich and Schubert, 2001; Pal and Eltahir, 2001).

Although the position of a Bermuda highpressure system typically is an important factor in the occurrence of droughts, other factors may influence a drought. During the summer of 2002 when hydrologic conditions reached record-low levels, a high-pressure system was present over the Gulf of Mexico, which is very rare during the summer (Mr. Ryan Boyles, North Carolina State Climate Office, written commun., February 23, 2004). The presence of this system reduced the availability of potential moisture in the southeastern States and exacerbated drought conditions in North Carolina.

Recent advances in meteorological research have expanded the recognition and understanding of global climate patterns that have important effects on weather in North Carolina. One such pattern is the El Niño-Southern Oscillation (ENSO), a climatic event characterized by alternating swings in sea-level pressures between the eastern and western Pacific Ocean near the equator and accompanied by changes in ocean water temperatures (National Oceanic and Atmospheric Administration, 2002). ENSO occurrences have been linked to climatic anomalies around the world. Under typical ENSO conditions, ocean temperatures generally range from warmer levels in the western Pacific to cooler levels in the eastern Pacific (fig. B-2A). During a warm ENSO event (referred to as El Niño), warmerthan-normal water temperatures occur in a
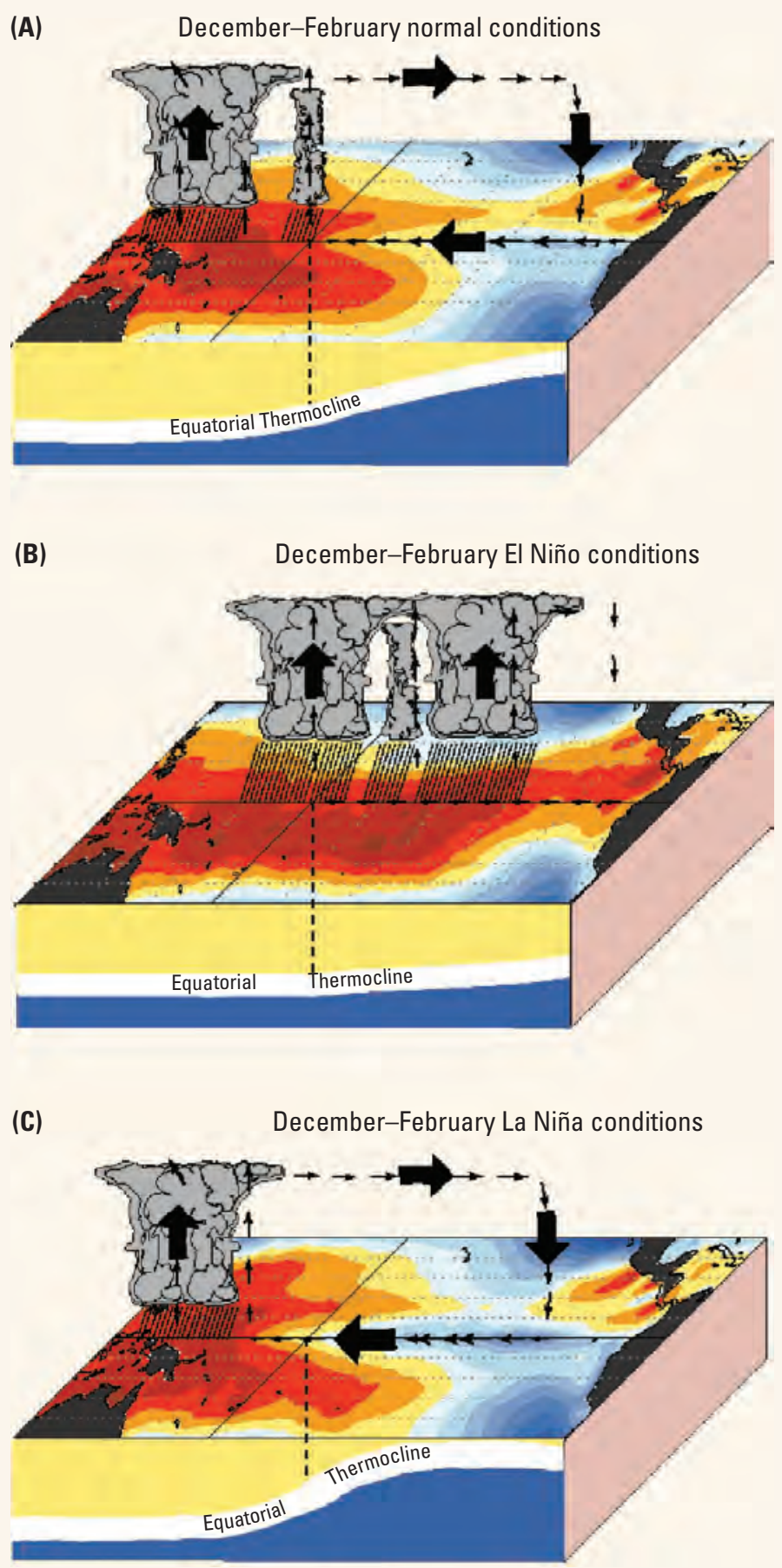

Note:

1. General atmospheric circulation (wind) patterns are denoted by arrows.

2. Surface-water temperatures are denoted by shaded colors ranging from blue (cooler) to red (warmer).

Figure B-2. Circulation patterns and surface-water temperatures from December through February during a (A) normal ENSO event, $(B)$ warm ENSO (El Niño) event, and (C) cool ENSO (La Niña) event (adapted from National Oceanic and Atmospheric Administration, 2002). 
large area of the eastern and central Pacific concurrent with existing warm temperatures in the western Pacific (fig. B-2B). In contrast, water temperatures in the eastern and central regions of the equatorial Pacific are cooler than normal during a cool ENSO event (La Niña), and warm temperatures are limited to the far western Pacific (fig. B-2C).

The effects of ENSO events on climate in the United States appear to be more evident during the winter months. In particular, winters during El Niño periods tend to be mild in the northeast and central United States and wet along the Gulf of Mexico (fig. B-3B). Prior to the 1998-2002 drought, above-normal precipitation occurred during late winter and early spring of the 1998 water year. Likewise, in the 2003 water year following the drought, above-normal precipitation occurred across much of North Carolina. In the southeastern United States and Mexico, precipitation recorded from October through March was above normal during 18 of 22 (81 percent) ENSO periods studied by Ropelewski and Halpert (1986).

By contrast, winter and spring precipitation in the southeastern United States tends to be below normal during La Niña periods (fig. B-3A). The occurrence of dry winters during the 1998-2002 drought was a critical factor in the severe drought conditions that developed in the western areas of the State. During the January-March quarters of 1999-2002, precipitation patterns were below normal over most of North Carolina.

summed for each water year and the drought period-May 1998 through September 2002 (fig. 4; table 1). The months prior to the drought and the 2003 water year following the drought also were examined to document the extent of changes in precipitation that occurred.

\section{Assessment of Precipitation During the 1998-2003 Water Years}

Precipitation patterns during the 1998 water year were marked by two contrasting patterns. During the winter and early spring, strong El Niño conditions in the Pacific Ocean resulted in

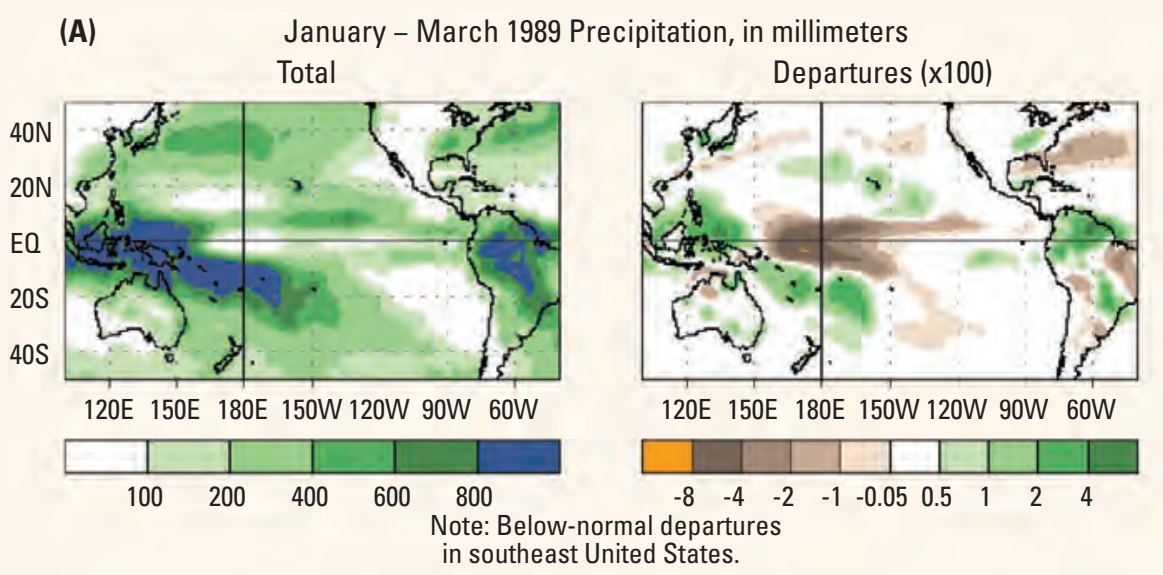

(B) January - March 1998 Precipitation, in millimeters

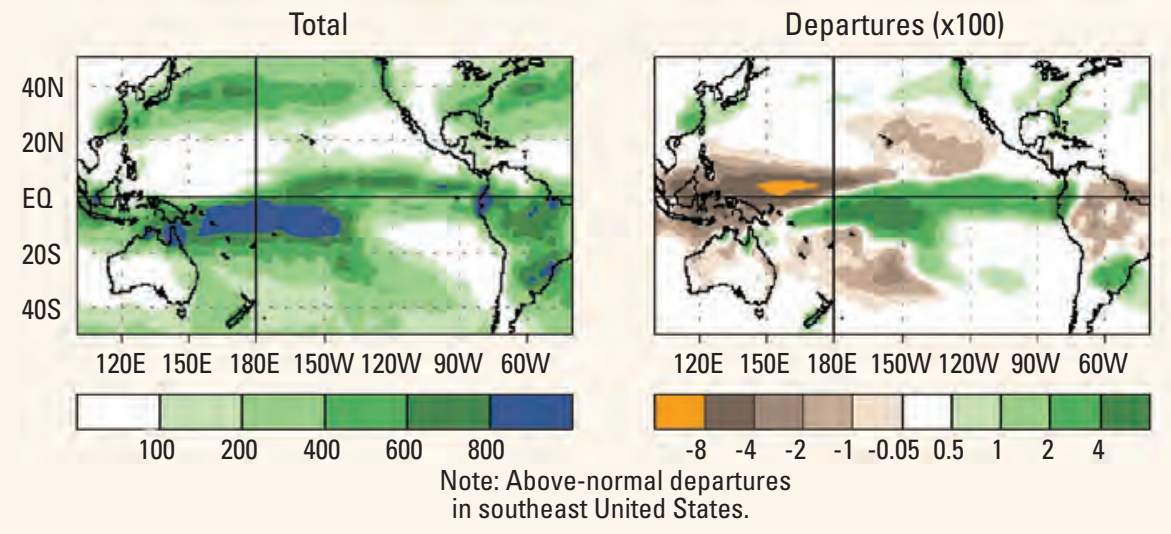

Figure B-3. Precipitation and associated departures from normal during January through March quarter over the tropical Pacific during a (A) cool ENSO (La Niña) event in 1989 and (B) warm ENSO (El Niño) event in 1998 (adapted from National Oceanic and Atmospheric Administration, 2002; shown in system international units). above-normal precipitation throughout much of North Carolina. During the 6-month period from October 1997 through March 1998, cumulative monthly precipitation across the State generally ranged from about 2 inches above normal at some locations in the Blue Ridge and Piedmont Provinces to nearly 11 inches above normal in Fayetteville in the Coastal Plain Province. Only 2 (Cullowhee and Mount Airy) of the 13 NOAA stations used for this report had precipitation totals less than 1 inch above normal for the 6-month period. Much of the abovenormal precipitation occurred during the second quarter (January through March) of the 1998 water year, as evidenced by precipitation totals more than 5 inches above normal at 6 of the 13 NOAA precipitation stations, located primarily in the eastern Piedmont and Coastal Plain Provinces.

Beginning in May 1998, rainfall patterns began to change from abovenormal to below-normal trends, particularly in the western half of the State. Cumulative monthly rainfall from May through September 1998 ranged from nearly 3.1 inches above normal at Wilmington to about 7.8 inches below normal at Fayetteville (table 1). Cumulative monthly rainfall during this 5-month period for Hickory, Mocksville, and Asheville was between 7 and 8 inches below normal, indicating that 

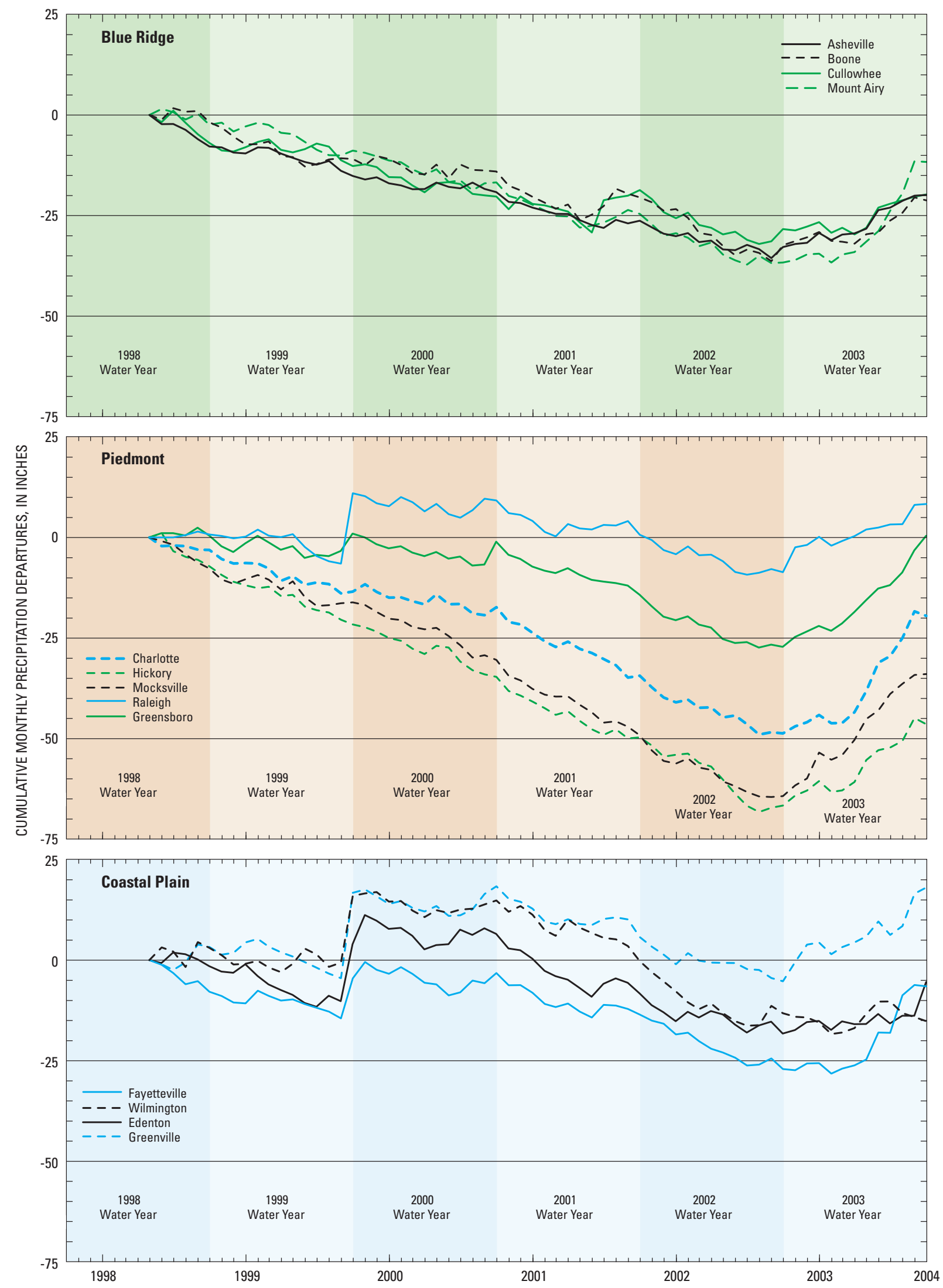

Figure 4. Cumulative monthly precipitation departures at selected National Oceanic and Atmospheric Administration precipitation stations in North Carolina by physiographic province, May 1998 through September 2003. 


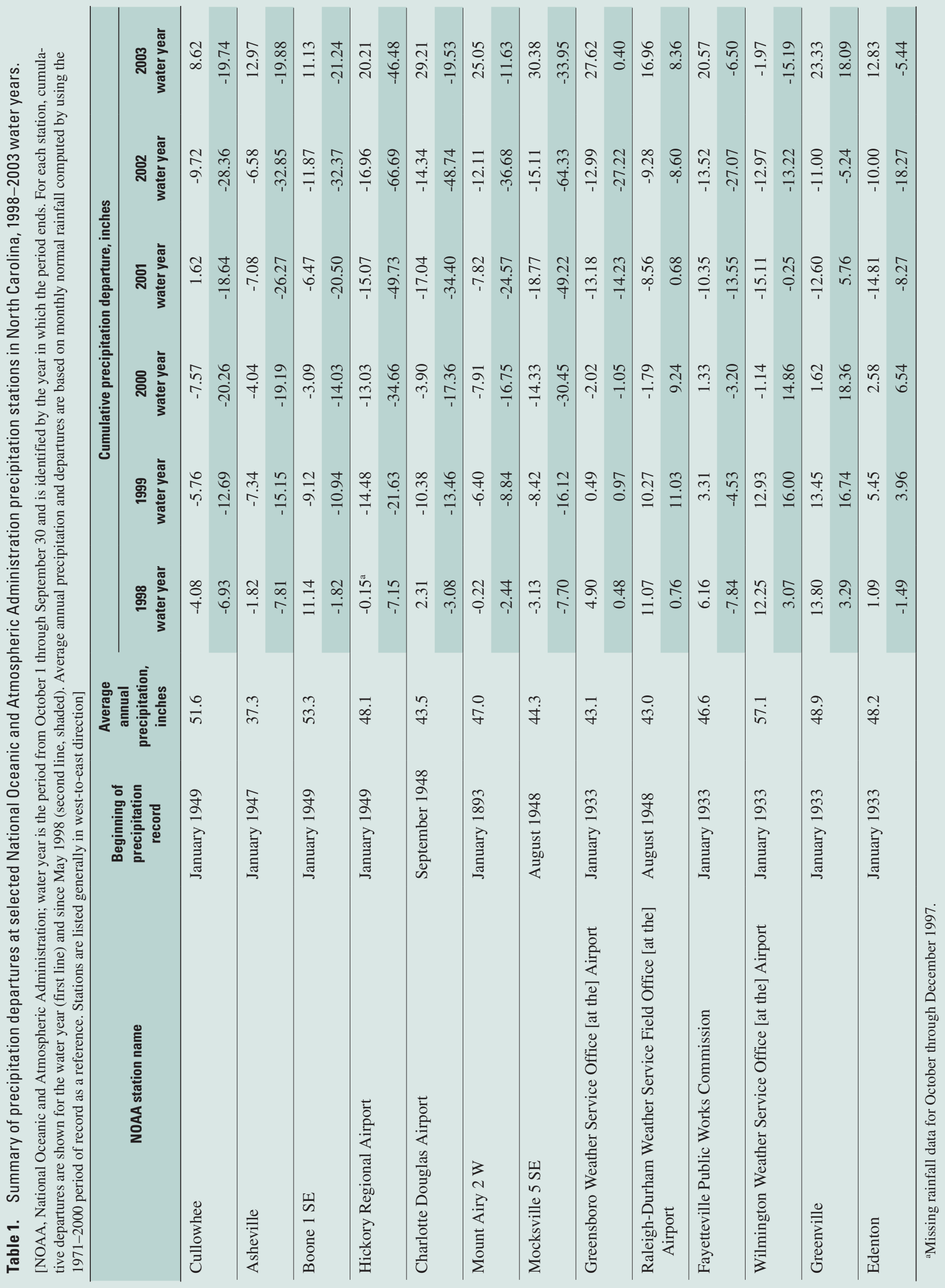


the initial effects of the drought were more pronounced in the Blue Ridge and western Piedmont Provinces.

Precipitation during the 1999 water year continued to be below normal for all of North Carolina until late August and September 1999 when record rainfalls occurred in much of the eastern part of the State as a result of several tropical storms. Most notable among these was Hurricane Floyd, which brought widespread catastrophic flooding in the lower Roanoke, Tar, Neuse, and lower Cape Fear River basins (Bales and others, 2000). The absence of significant precipitation in western North Carolina, however, intensified drought conditions in that part of the State. Precipitation at the Hickory Regional Airport during the 1999 water year was nearly 14.5 inches below normal, resulting in a deficit of about 21.6 inches since the beginning of the drought (about 18 months in duration by September 1999; table 1). Similarly, precipitation totals at Asheville, Charlotte, and Mocksville ranged from 7.3 to 10.4 inches below normal during the 1999 water year, bringing the total deficits at these locations to about 13 to 16 inches since the beginning of the drought. Some Piedmont and Coastal

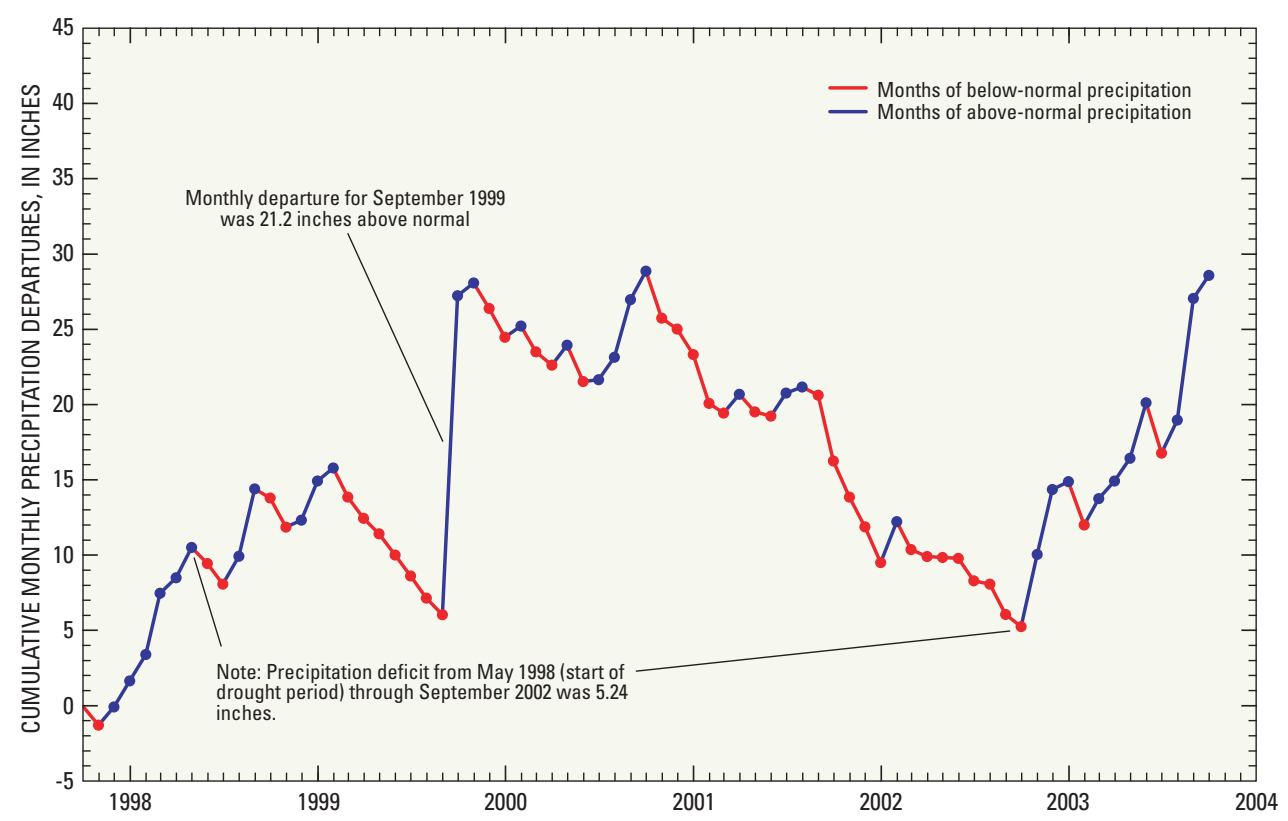

Figure 5. Cumulative monthly precipitation departures at the Greenville, N.C., precipitation station, October 1997 through September 2003.
Plain streams in eastern North Carolina, where the tropical storms occurred, had an immediate but temporary reprieve from the drought conditions. Rainfall totals for the month of September alone ranged from about 10 to 21 inches above normal in Raleigh, Fayetteville, Wilmington, Greenville (fig. 5), and Edenton.

Below-normal precipitation patterns continued for most of North Carolina throughout much of the 2000 water year, although deficits were not as large as those observed at some locations during the 1999 water year. For example, precipitation at Asheville for the 12-month period was 4.0 inches below normal compared to about 7.3 inches below normal during the 1999 water year (table 1). Similarly, precipitation at Charlotte totaled 10.4 and 3.9 inches below normal for the 1999 and 2000 water years, respectively. Further similarities in this pattern also were noted for the NOAA sites in the eastern Piedmont and Coastal Plain, especially during the summer of 2000 when varying amounts of above-normal rainfalls were recorded. Despite a year during which precipitation trends indicated some improvement, precipitation totals at Mocksville and Hickory were 14.3 and 13.0 inches below normal, respectively, during the 2000 water year. Thus, the total deficits for the drought at these locations increased to 30.5 and 34.7 inches, respectively.

During the 2001 water year, below-normal precipitation continued, further intensifying the drought across North Carolina. At Asheville and Charlotte, precipitation totals were 7.1 and 17.0 inches below normal, respectively, for the 12-month period, raising the total deficits at these locations to 26.3 and 34.4 inches, respectively (table 1). At Mocksville and Hickory, precipitation during the 2001 water year was 18.8 inches and 15.1 inches below normal, bringing the total deficits to 49.2 and 49.7 inches, respectively. These deficits exceeded respective average annual precipitation for these locations, meaning that the equivalent of more than one year's rainfall did not occur during the 3.5-year period since the beginning of the drought. In the eastern Piedmont and Coastal Plain, precipitation deficits during the 2001 water year were somewhat smaller, ranging from 8.6 inches in Raleigh to 14.8 inches in Edenton. The 12-month precipitation totals varied widely at the eastern Piedmont and Coastal Plain locations, resulting in departures since the beginning of the drought that ranged from about 5.8 inches above normal (surplus) at Greenville to about 13.6 inches below normal (deficit) at Fayetteville. The smaller departures for the eastern locations relative to those in western North Carolina were a lingering result of the above-normal rainfall that occurred in fall 1999 (Hurricanes Dennis, Floyd, and Irene).

During the 2002 water year, precipitation totals across the State generally were deficient, ranging from nearly 6.6 inches below normal at Asheville to almost 17 inches below normal at Hickory (table 1). In most areas of North Carolina, however, the last month of below-normal rainfall occurred in July or August 2002 with the arrival of significant rainfalls in 
late August and September. Cumulative deficits beginning in May 1998 at Hickory and Mocksville reached 68.3 and 64.6 inches, respectively, during July and August 2002 (figs. 6, 7). Considering that the average annual precipitation for these locations is 48.1 and 44.3 inches, respectively, the deficit totals were equivalent to almost 18 months of no precipitation during the drought. The deficit for Charlotte reached 49.0 inches between May 1998 and July 2002 (fig. 8), a deficit that was nearly 5.5 inches greater than the average annual precipitation (table 1). At six other precipitation stations analyzed for this report, primarily in the western Piedmont and Blue Ridge Provinces, deficits did not exceed the respective average annual precipitation, but did exceed 25 inches during the drought.

Above-normal rainfall began in late August 2002 and continued into the 2003 water year because of El Niño conditions that began in early fall 2002. The increased rainfall helped reduce the deficits that had accumulated during the drought. Most of the significant reduc-

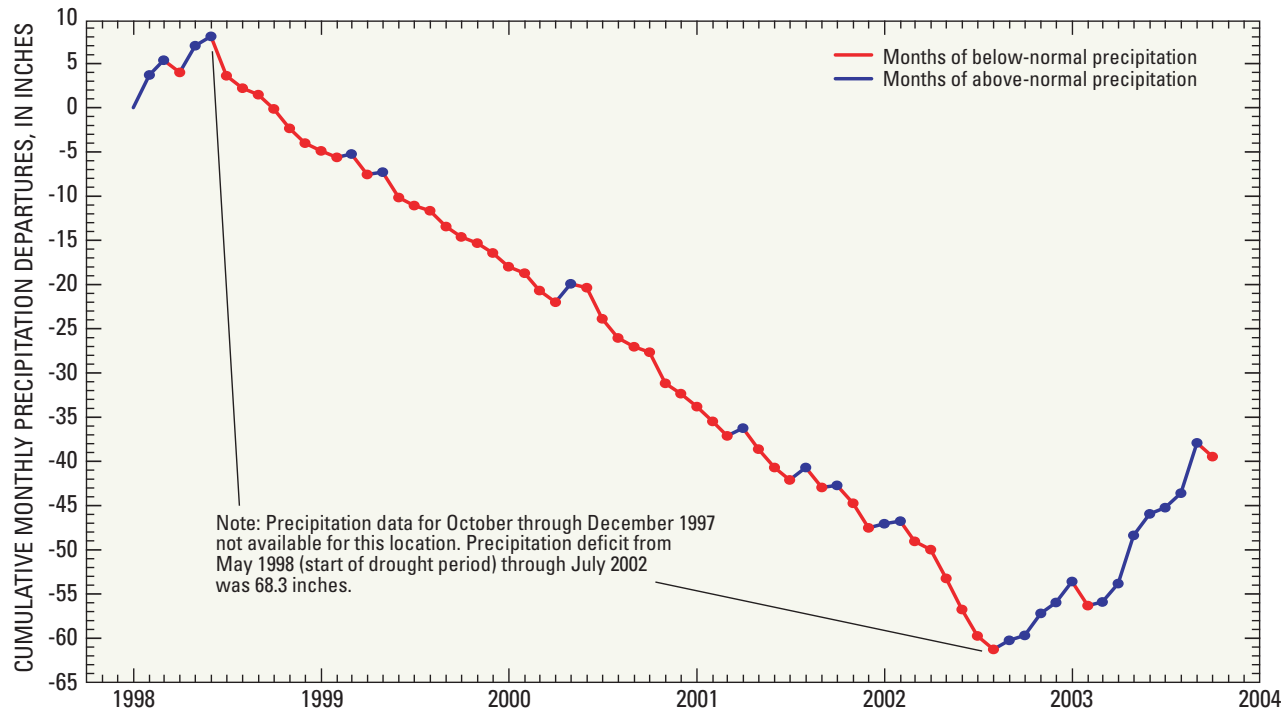

Figure 6. Cumulative monthly precipitation departures at the Hickory Regional Airport precipitation station in North Carolina, October 1997 through September 2003.

tions in the deficits occurred during the late winter and spring. The only month in which below-normal precipitation occurred across much of North Carolina was January, raising concerns on the part of local and State officials that drought conditions could be returning. During the 2003 water year, precipitation totals ranged from almost 2 inches below normal at Wilmington to 30.4 inches

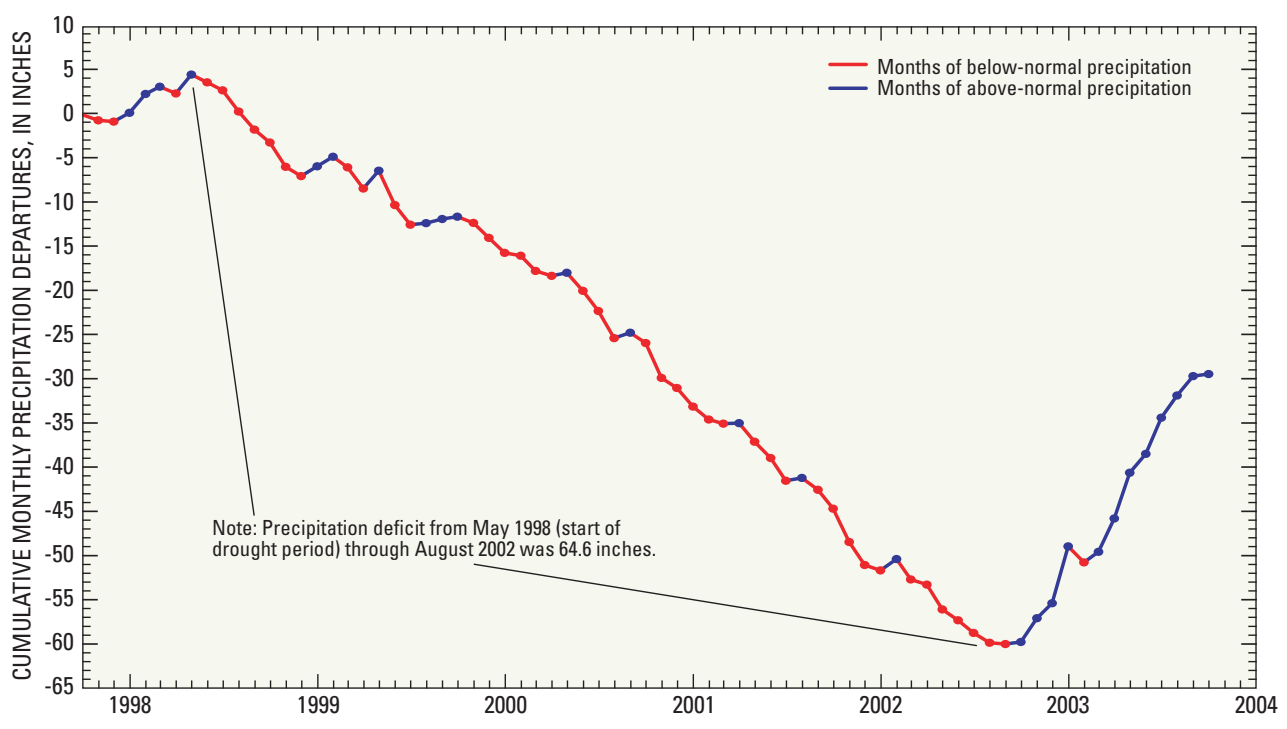

Figure 7. Cumulative monthly precipitation departures at the Mocksville, N.C., precipitation station, October 1997 through September 2003. above normal at Mocksville (table 1). Of the 13 precipitation stations examined for this report, 11 had precipitation totals greater than 10 inches above normal during the 2003 water year. Further, precipitation totals at 7 of the 11 stations exceeded 20 inches above normal for the same period, primarily in the western Piedmont where the highest deficits had been recorded during the drought.

While below-normal precipitation totals occurred during most months of the 1998-2002 drought, of particular note are the totals during the first quarters (January through March) of 1999-2002 at many of the 13 locations. Assessment of historical hydrologic data indicates that winter periods are crucial to the recharging process and overall maintenance of water in the hydrologic system, as evidenced by increased streamflow rates and higher ground-water levels during the winter. The combination of lower evaporative losses and decreased demands during the winter results in increased water storage, particularly in reservoirs and ground-water systems. Thus, 


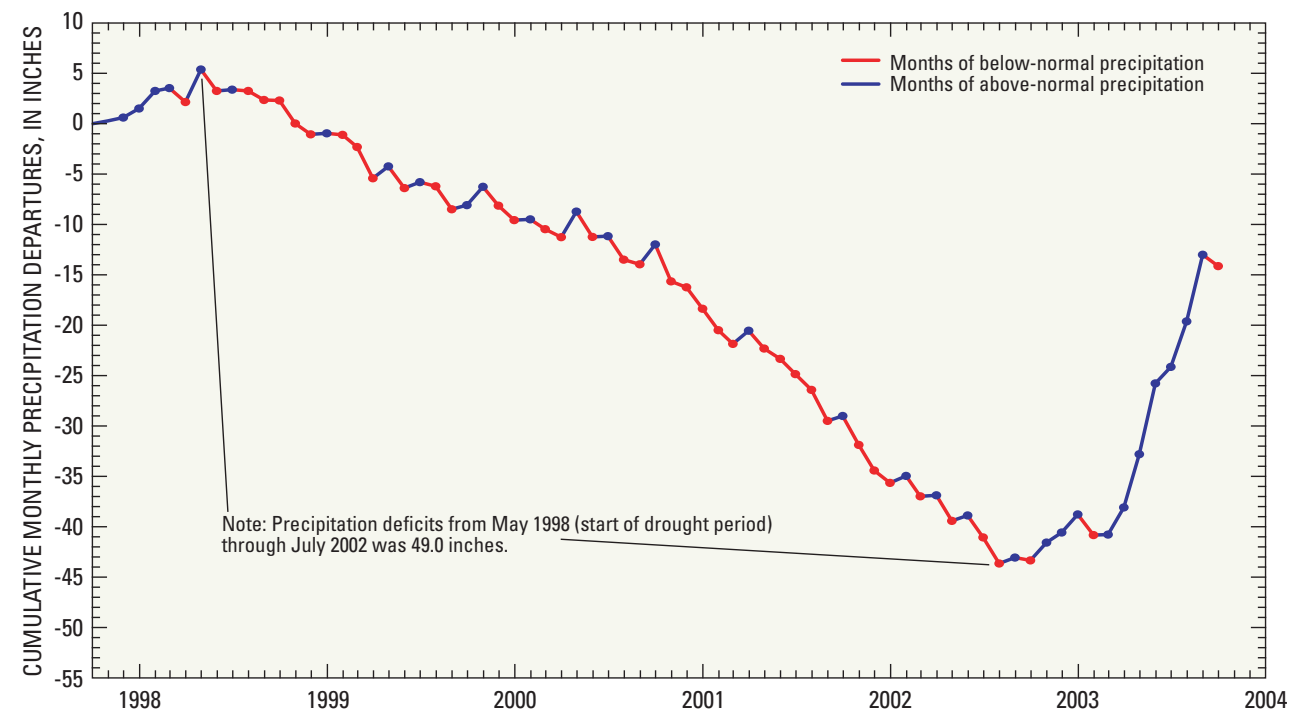

Figure 8. Cumulative monthly precipitation departures at the Charlotte Douglas Airport precipitation station in North Carolina, October 1997 through September 2003.

during the summer and fall, the stored water helps to maintain streamflow and ground-water levels during periods of normal seasonal declines. With the exception of Fayetteville in 1999, and Greenville and Edenton in 2002, precipitation totals during the first quarter of each year from 1999 through 2002 were below normal. The occurrences of consecutive "dry winters" exacerbated the overall drought, resulting in the extreme low hydrologic conditions observed during the summer of 2002.

Another perspective of the below-normal precipitation patterns during the drought is evident in the "monthly" percentages of annual totals for 8 of the 13 precipitation stations. At each of the stations, moving 12-month totals through each month from October 1997 through September 2003 were expressed as a percentage of normal (average annual) precipitation. The patterns show the cumulative effect of precipitation deficits and, thus, are good indicators of the severe drought conditions that were observed across the State, particularly in areas of the Piedmont. At
Mocksville and Hickory, 12-month totals were almost consistently below 80 percent for nearly 3.5 years (February 1999 through mid-2002) and below 70 percent for more than 18 consecutive months (November 2000 through mid-2002) just prior to the onset of above-normal precipitation that eventually relieved the drought conditions by mid-2003 (fig. 9). The lowest percentages were at Mocksville where 12-month totals were at or below 60 percent for 14 of 19 months from January 2001 through August 2002 (fig. 9). The 12-month percentages in figure 9 also depict the variation in precipitation patterns in eastern North Carolina (Raleigh, Fayetteville, Greenville) beginning in fall 1999 as a result of tropical storms.

At all stations, the reversal in precipitation patterns from late summer 2002 through September 2003 can be noted in the rapid and simultaneous percentage increases during this period. As previously discussed, areas in the Piedmont having the highest deficits during the drought also had some of the highest 12-month percentages by September 2003. The 12-month precipitation totals at Charlotte, Mocksville, and Greensboro were between 160 and 170 percent of annual average precipitation near the end of this period (fig. 9).

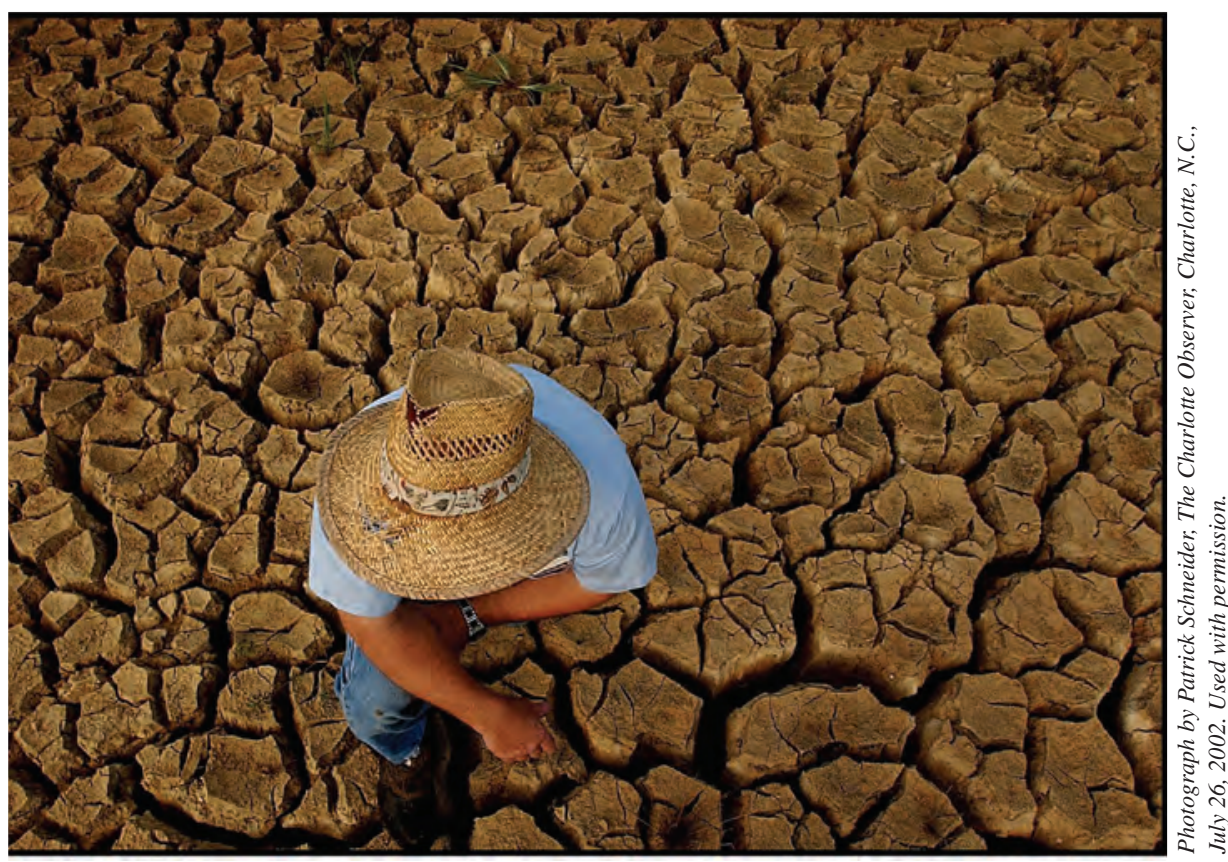

A farmer in York, S.C., kneels in his dried-up watering pond, which normally would be a primary watering source for his 80 -head of beef cattle. 

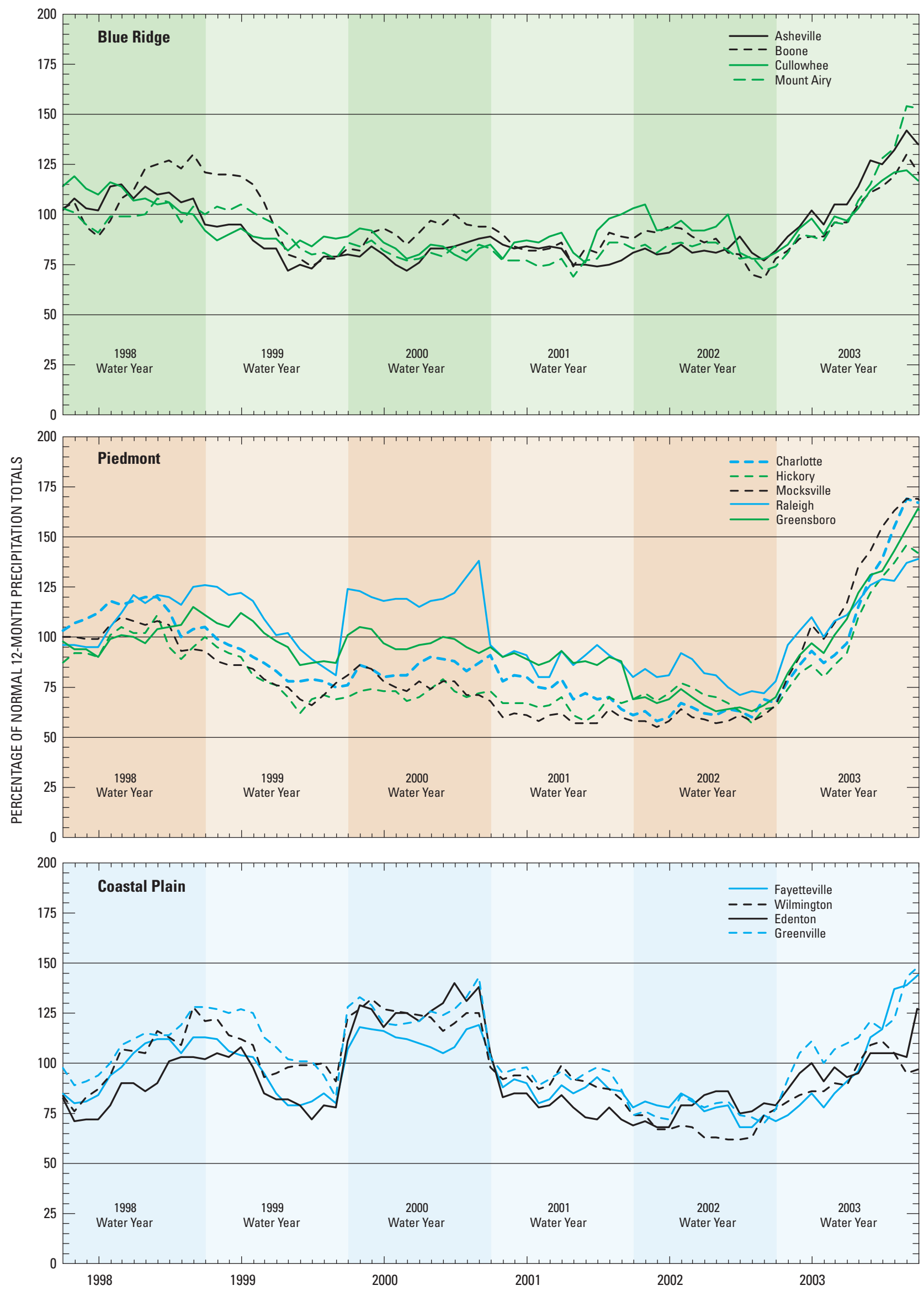

Figure 9. Percentage of normal moving 12-month precipitation totals for selected National Oceanic and Atmospheric Administration precipitation stations in North Carolina, October 1997 through September 2003. 


\section{Use of Drought Indices to Assess Droughts}

The monitoring and assessment of a drought are often a challenge to officials because of the differing effects and varying conditions that usually occur across a large region. Drought indices are used to categorize the extent and severity of a drought by combining various pieces of information about a drought into a numerical index for a defined time scale or region. Drought indices provide objective criteria for planning and initiating conservation and other response measures to help alleviate the effects of a drought.

Nearly a dozen drought indices have been developed since the early 1900s (Heim, 2002). The fact that numerous indices have been devised indicates the challenges associated with developing a simple measure of droughts that can be used for different purposes in different regions or to compare an existing drought with historical droughts. Many of the indices developed prior to 1950 were based solely on meteorological parameters of precipitation and temperature. Beginning in the mid-1950s, drought indices began to include measures of soil moisture and eventually surface-water or groundwater levels to provide more comprehensive drought characterization (Heim, 2002). Some of the most well known or recently developed drought indices are described in this section.
- Percent of normal precipitation - For the general public, the percent of normal precipitation is the most easily understood drought index and is one that can be based on various time periods (month, season, or year). However, this index is only meaningful for a single period or region (National Drought Mitigation Center, 2003c). For instance, precipitation amounts considered below normal in many parts of the eastern United States usually are above normal for some areas in the southwestern States. The percent of normal precipitation can change quickly in a matter of a few weeks or months while the deeper effects of a drought may still be present. An example of this was observed beginning in August and September 2002 when above-normal rainfalls began to occur across much of North Carolina after about 4 years of below-normal precipitation. During the initial months when the meteorological drought recovery began, the hydrological drought was still in effect because of continued below-normal hydrologic conditions, particularly in the western Piedmont. It was not until the late winter and spring of 2003 that hydrologic conditions reached normal ranges and were sustained thereafter. Thus, the percent of normal precipitation can be misleading because it does not fully describe the broader effects of a long-term drought.
- Palmer Drought Severity Index - One of the first comprehensive indices that is still widely used is the Palmer Drought Severity Index (PDSI), developed by W.C. Palmer in 1965 and subsequently modified into other similar measures called the Palmer Z Index, Crop Moisture Index, and Palmer Hydrological Drought Severity Index (Heim, 2002; National Drought Mitigation Center, 2003c). Known operationally as the Palmer Drought Index or Palmer Index, the PDSI is a meteorological index based on precipitation, temperature, and soil-moisture data used in a water balance equation to account for evaporation, soil recharge, runoff, and moisture loss from the Earth's surface (National Drought Mitigation Center, 2003c). The Palmer classification scale ranges from -4.0 to +4.0 or more, defining extreme drought to extremely wet conditions, respectively. A PDSI value of zero indicates normal weather conditions. The purpose of the PDSI is to provide measurements of standardized moisture conditions so that comparisons can be made between soil-moisture conditions in different areas and months. However, some limitations of the PDSI have been identified. The PDSI values may lag emerging droughts by several months, making the PDSI unsuitable for areas with climatic extremes and typically overstating the frequency of drought

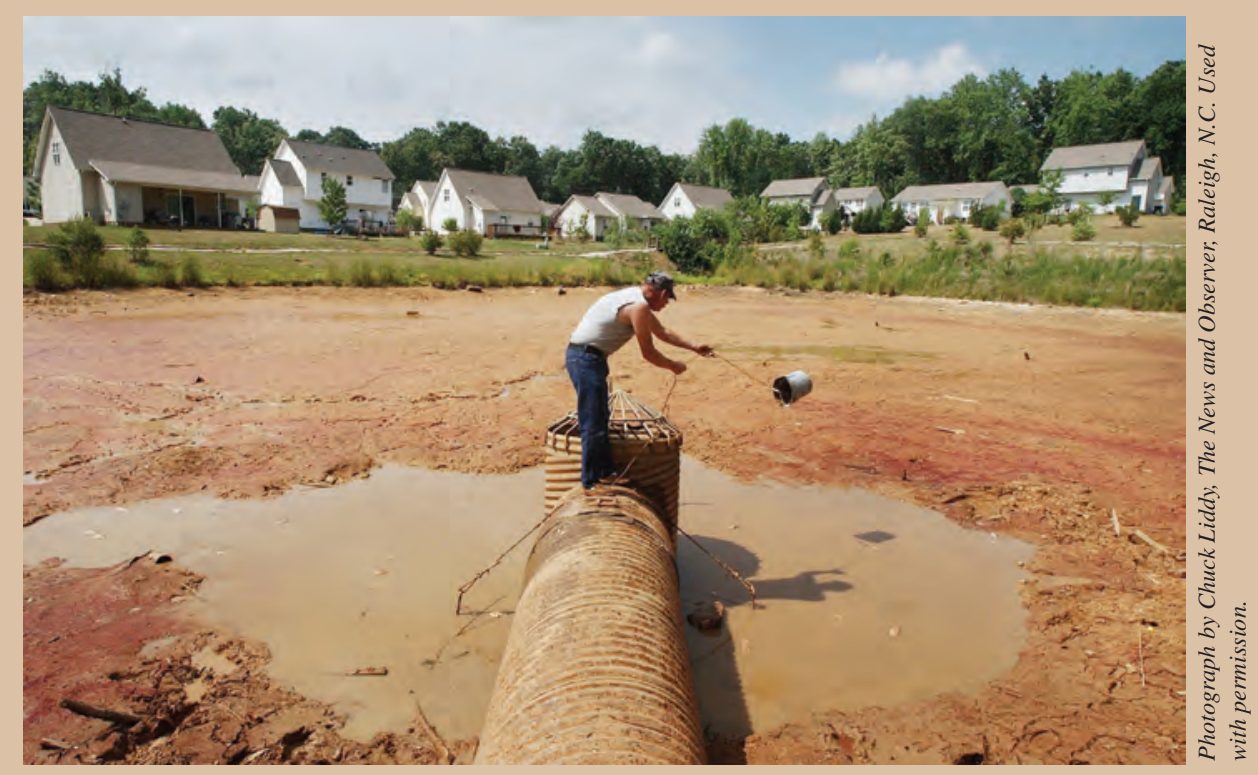

A man uses a bucket and rope to try and save fish that are suffocating in a dried-up pond in Hillsborough, N.C., June 30, 2002. 
occurrence. For instance, the PDSI suggests that much of North Carolina could experience extreme drought conditions during July about once every 20 years, a fairly frequent occurrence of what is considered an extreme event (Willeke and others, 1994; Bales and others, 2003).

Recent research in the field of paleoclimatology has resulted in the quantification of historical annual PDSI values based on a network of tree-ring chronologies across the United States (National Oceanic and Atmospheric Administration, 2003b). Using data from more than 350 trees, a grid (across the conterminous United States) of PDSI values for the summer (June-August) period was developed for each year between 1700 and 1979 (National Oceanic and Atmospheric Administration, 2003b). Likewise, weather records dating from 1895 also have been used to compute similar PDSI values for comparison with those quantified using the tree-ring data. A general overlay of concurrent years indicates that values based on the tree rings correlated fairly well with those computed from the weather records. However, the PDSI values based on tree-ring data do not indicate the degree of severity and variability in PDSI values based on weather records. Nevertheless, the availability of PDSI values based on tree-ring chronologies can provide insight into significant drought periods that occurred prior to the start of weather records (National Oceanic and Atmospheric Administration, 2003b).

The tree-ring-based PDSI values for one of the grid points (near Charlotte) are available for the period 1677 through 1979 (figs. C-1, C-2). Prior to the start of weather records, moderate droughts (reaching values of -2.0 or more on the Palmer index) appear to have occurred in North Carolina during several periods: $1705-10,1745-60$, and 1805-20. The PDSI values based on weather records also identify periods of moderate droughts in the early 1910s, much of the 1920 s and early 1930s, most of the 1950s, and the mid-1980s.

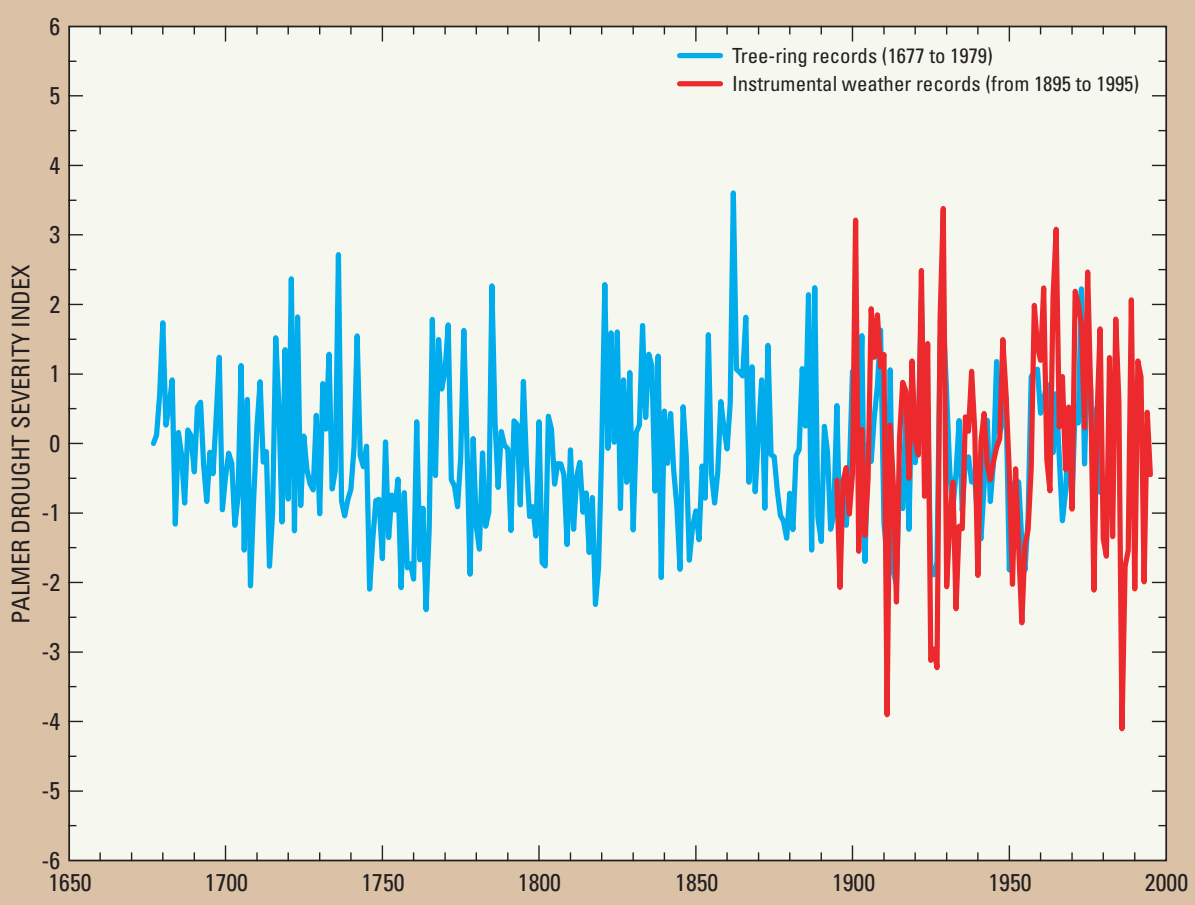

Figure C-1. Reconstructed historical Palmer Drought Severity Index values for the period 1677 through 1979 (based on tree rings) and 1995 (based on weather records) (adapted from National Oceanic and Atmospheric Administration, 2003b).

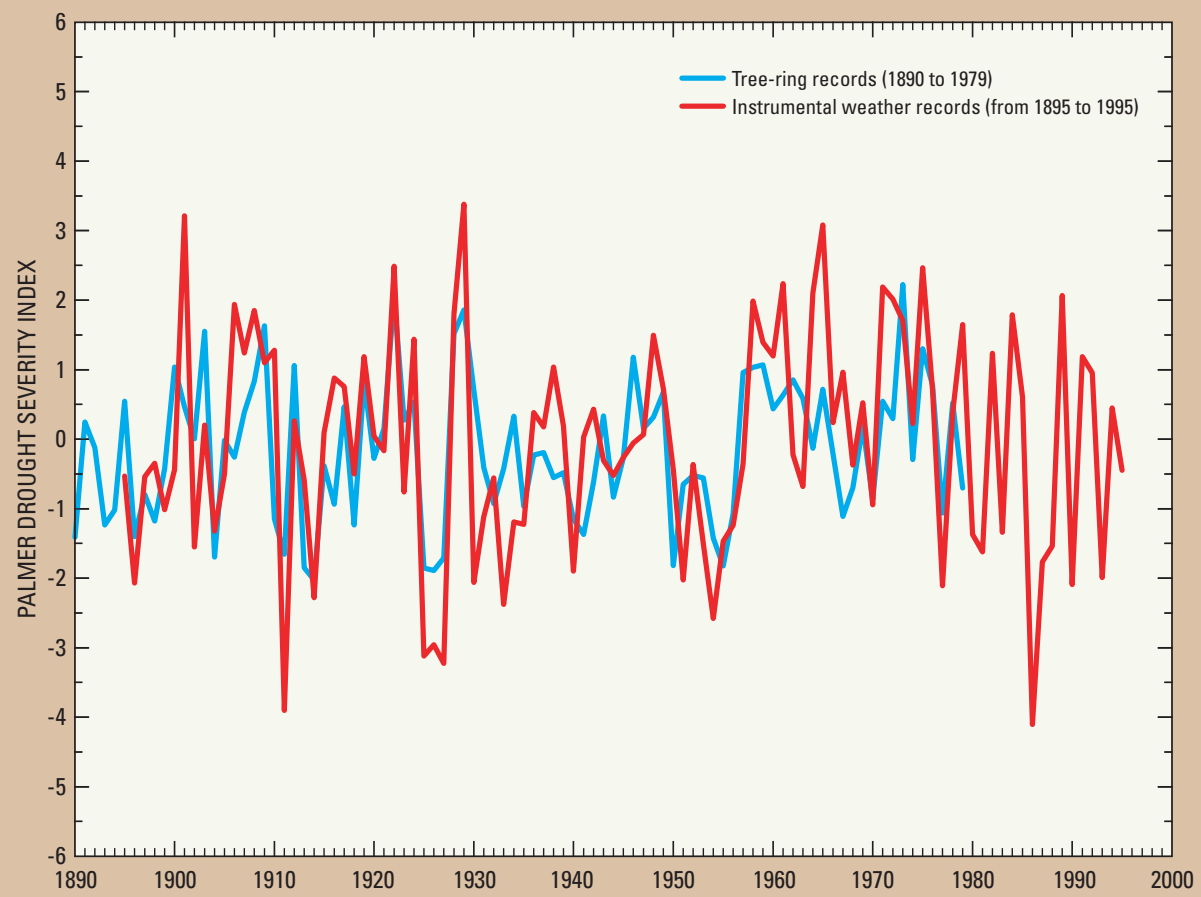

Figure C-2. Reconstructed historical Palmer Drought Severity Index values for the period 1890 through 1979 (based on tree rings) and 1995 (based on weather records) (adapted from National Oceanic and Atmospheric Administration, 2003b). 
- Palmer Z Index and Crop Moisture Index - While the PDSI has been used widely to assess long-term drought, a variation known as the Palmer Z Index is used to assess short-term drought on a monthly basis (National Oceanic and Atmospheric Administration, 2004a). Another variation of the PDSI is the Crop Moisture Index (CMI), which is used to assess shortterm drought on the basis of weekly changes in moisture conditions (National Oceanic and Atmospheric Administration, 2004a). The CMI was designed specifically for use in assessing agricultural droughts.

- Palmer Hydrological Drought Index - The Palmer Hydrological Drought Index (PHDI) was designed to avoid the quick changes that occur in PDSI values in response to brief changes in weather patterns. For example, as measured by the PDSI, the drought ends when conditions change from dry to normal or wet, without regard to the long-term effects on hydrologic conditions (streamflow, ground water, lakes, and reservoir levels; Karl and Knight, 1985; National Drought Mitigation Center, 2003c). The PHDI was designed to calculate the amount of precipitation needed to end a drought and is a measure of the long-term hydrological conditions; therefore, the index values respond more slowly to changing meteorological conditions than the PDSI (National Oceanic and Atmospheric Administration, 2001, 2004a). Historical PHDI values computed for North Carolina from 1900 through 2003 provide some insight into the significant drought periods of the 20th century (fig. C-3).

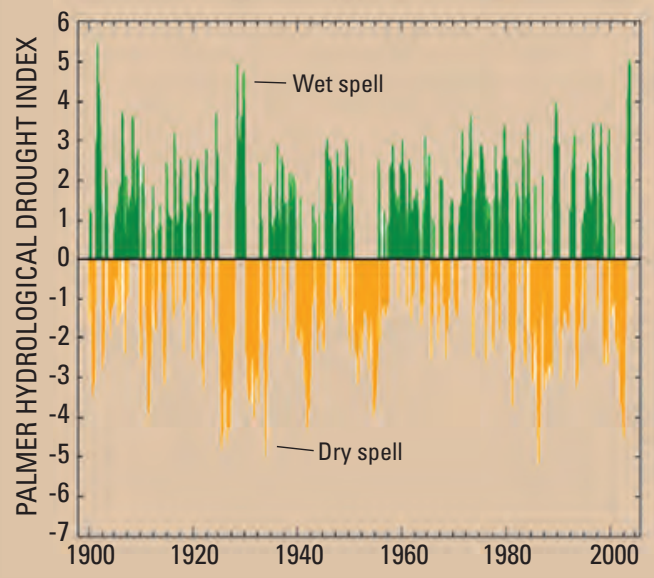

Figure C-3. Palmer Hydrological Drought Index values for North Carolina from 1900 through 2003 (adapted from National Oceanic and Atmospheric Administration, 2004b).
Similar to the PDSI values computed using tree-ring data, PHDI values reconstructed from tree rings for July suggest that severe

\section{Could severe drought conditions have been a factor in the fate of the Lost Colony?}

drought conditions occurred in southeastern Virginia and northeastern North Carolina during the earliest settlement periods in
United States history (National Oceanic and Atmospheric Administration, 2003b; (fig. C-4). In Manteo, North Carolina, a group of colonists arrived on Roanoke Island in 1587 and mysteriously disappeared prior to the subsequent arrival of more colonists and supplies in 1591. Historians have not been able to fully explain their disappearance, and some speculate that severe drought conditions may have been a factor in the tragic fate of the Lost Colony. Similarly, many colonists who settled in Jamestown,

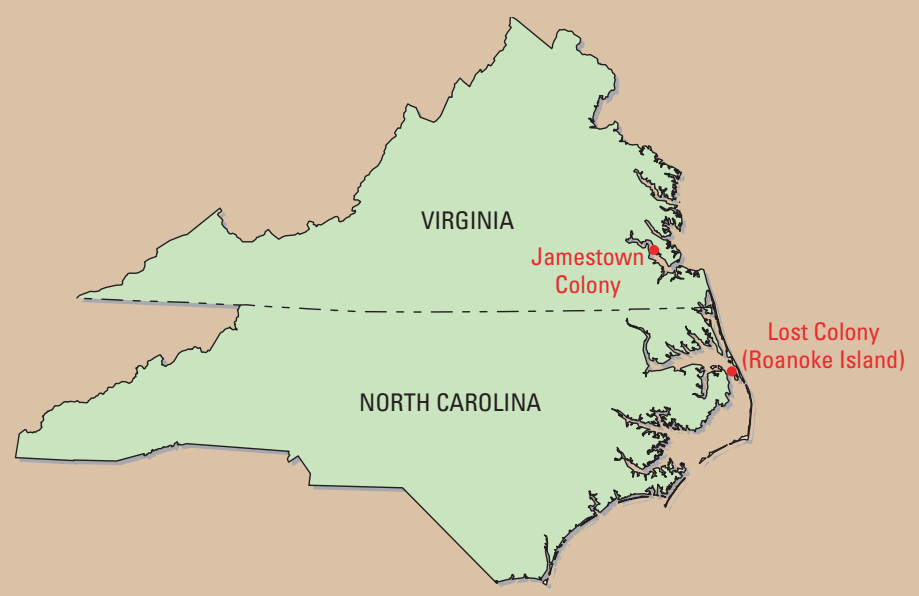

LOCATION OF JAMESTOWN COLONY IN VIRGINIA AND THE LOST COLONY (Roanoke Island) IN NORTH CAROLINA

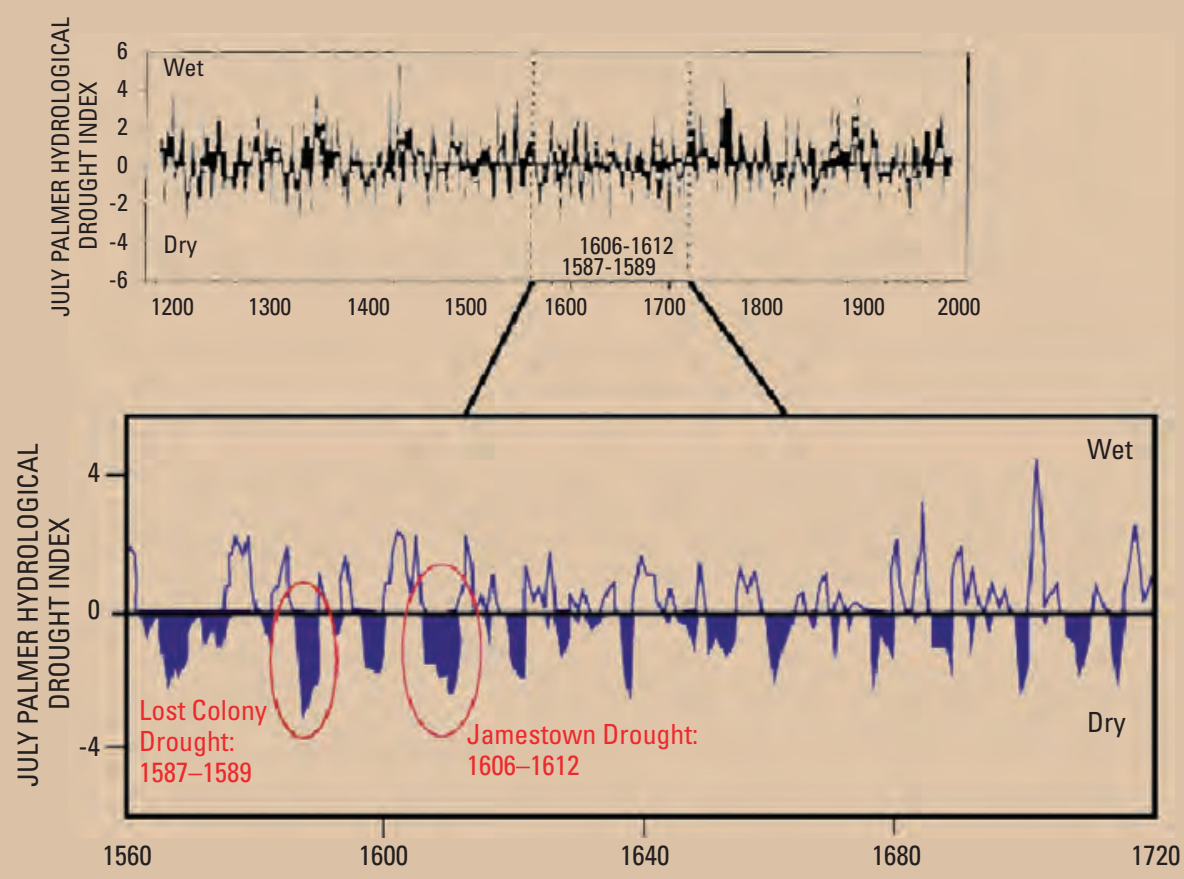

Figure C-4. Reconstructed historical Palmer Hydrological Drought Index values for July during the late 16th and early 17th centuries in southeastern Virginia and northeastern North Carolina (adapted from National Oceanic and Atmospheric Administration, 2003b). 
Virginia, during 1607-24 died, reportedly from malnutrition. Reconstructed PHDI values for July during these periods point to the occurrence of severe drought conditions, a possible additional hardship for these early settlers (National Oceanic and Atmospheric Administration, 2003b).

- Standardized Precipitation Index Developed in the early 1990's, the Standardized Precipitation Index (SPI) was designed to quantify precipitation departures for various time scales (Heim, 2002). The use of various time scales in the SPI reflects the different effects that droughts have on hydrologic conditions during the course of an event (National Drought Mitigation Center, 2003c). The SPI classification scale ranges from less than -2.0 to +2.0 or more, reflecting extremely dry to extremely wet conditions, respectively. A SPI value between -0.99 and +0.99 indicates near-normal conditions. The SPI maps are generated for periods ranging from 1 to 24 months. The SPI maps for the 12-month period through August 2002 at the height of the drought followed by the 9 -month period through May 2003 highlight the distinct patterns in precipitation that occurred across the eastern United States, but particularly in the western half of North Carolina (fig. C-5).

As previously discussed, the Palmer indices indicate the overall moisture conditions in a water-balance approach (National Oceanic and Atmospheric Administration, 2004a). However, the SPI is based on precipitation only and, thus, is considered a simpler and better index for providing early warning of drought conditions

A.

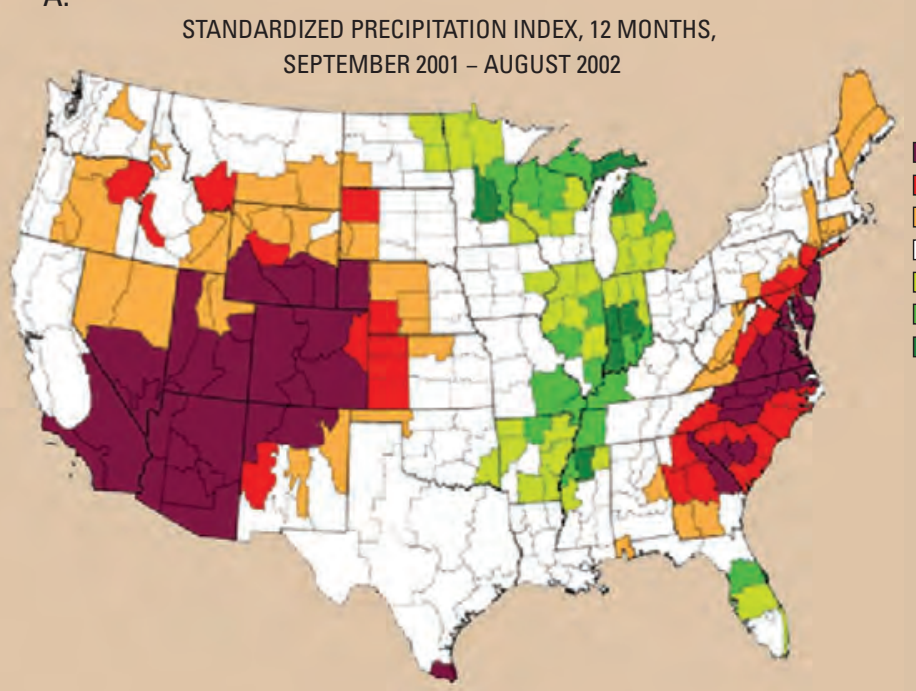

\section{EXPLANATION}

PRECIPITATION, IN INCHES

Extremely dry (less than -2

Severely dry (-1.50 to -1.99$)$

Moderately dry (-1.00 to -1.49$)$

Mid-range (-0.99 to 0.99$)$

Moderately moist (1.00 to 1.49 )

Very moist (1.50 to 1.99 )

Extremely moist (greater than 2.00)

\section{B.}

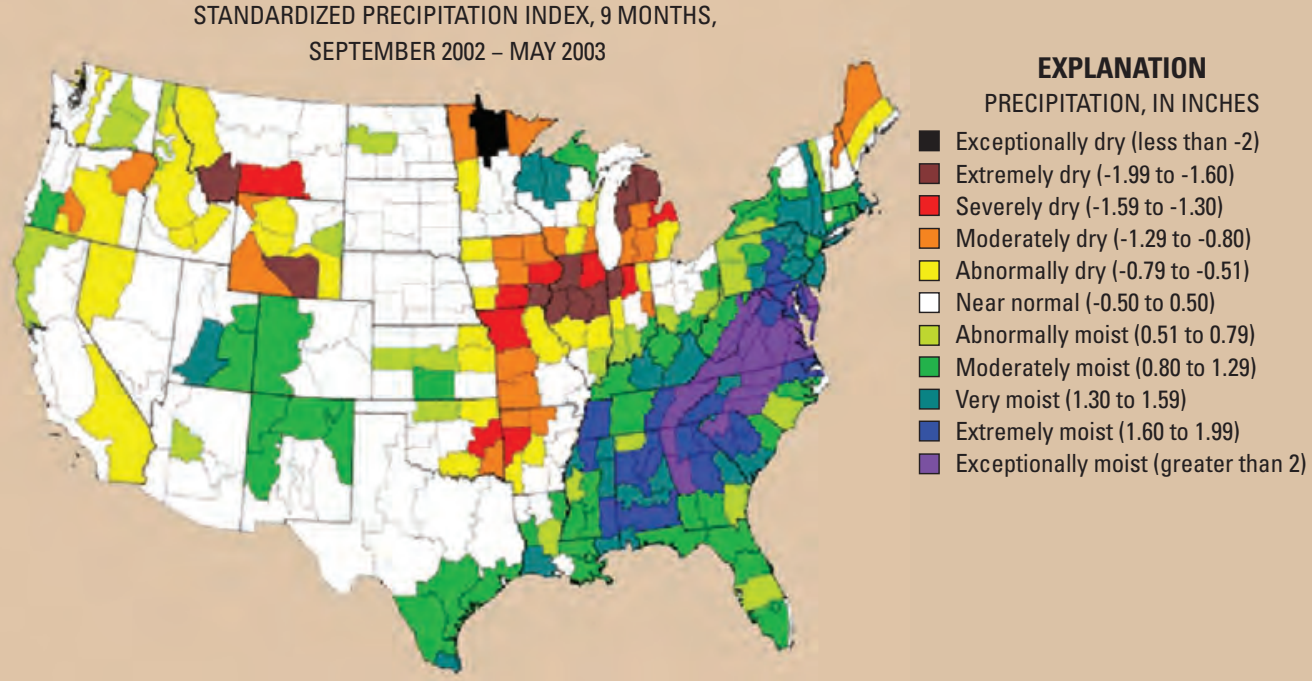

Figure C-5. Standardized precipitation index for the United States for the (A) 12-month period through August 2002 (at height of 1998-2002 drought in North Carolina) and (B) 9-month period from September 2002 through May 2003 (following drought recovery) (adapted from Mr. Richard Heim, National Climatic Data Center, written commun., March 3, 2004). 
and assessing drought severity (National Drought Mitigation Center, 2003c). Long-term precipitation data for a given location is fitted to a probability distribution, then transformed to a normal distribution so that the mean SPI for a given time scale is zero (Edwards and McKee, 1997). Because the SPI is normalized, both wet and dry climates can be represented in the same manner
(National Drought Mitigation Center, 2003c). The SPI also is regarded as a better indicator of drought frequency and magnitude than the Palmer indices, which suggest a higher frequency of occurrence of extreme droughts for some areas of the country.

- Drought Monitor - The Drought Monitor (DM) is the most recent tool for

A.

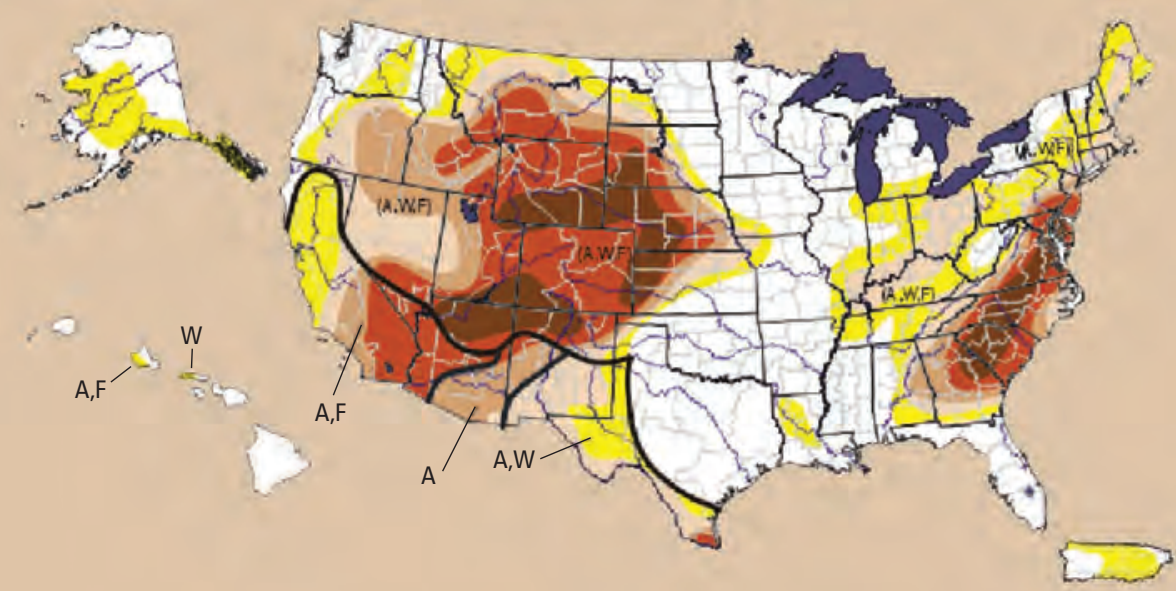

EXPLANATION

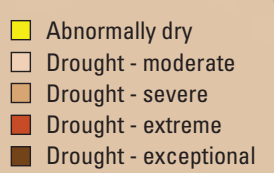

DROUGHT IMPACT TYPES

A Agriculture

$F \quad$ Fire danger (wildfires)

W Water (hydrological)

Delineates dominant impacts No type = all 3 types

B.

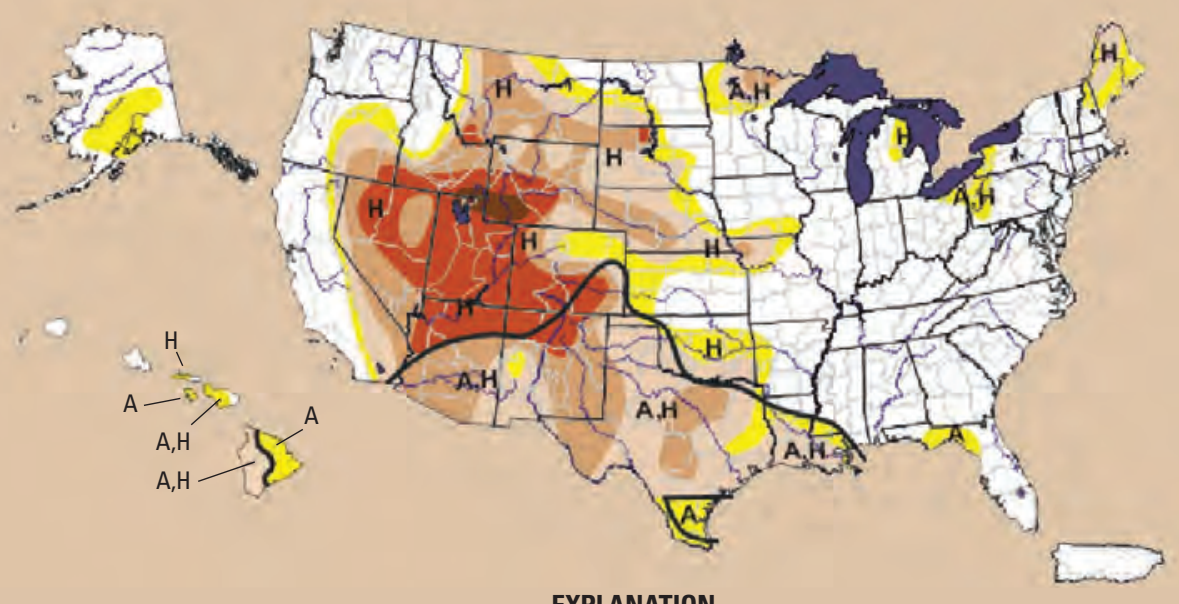

EXPLANATION

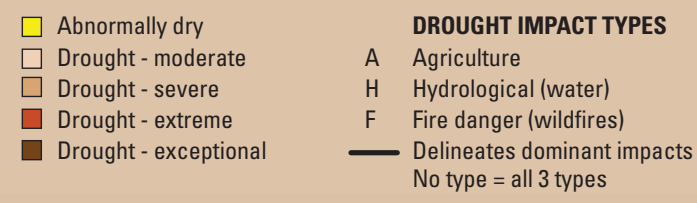

Figure C-6. Extent of drought conditions depicted by the U.S. Drought Monitor for (A) August 2002 (at the height of the 1998-2002 drought in North Carolina) and (B) May 2003 following drought recovery (adapted from National Drought Mitigation Center, 2003a).

monitoring and characterizing droughts (Heim, 2002; National Drought Mitigation Center, 2003c). Prepared on a weekly basis, the $\mathrm{DM}$ is released as a map image that depicts drought conditions based on a 5 -scale system that ranges from abnormally dry to exceptional drought conditions. Its strength and usefulness as a monitoring tool is perhaps grounded in the recognition that the DM is not a separate index comparable to the indices that already exist. Rather, it represents the simultaneous assessment of multiple key indicators plus a number of supplementary measures (National Drought Mitigation Center, 2003a). The DM was designed to provide a general assessment of drought conditions across the United States and was not intended to override any specific local or state drought assessments (Heim, 2002). In fact, one of its strengths is the inclusion of local input from different regions across the country after the key and supplementary indicators have been computed. Such input allows a reality check to be factored into the final assessment of existing drought conditions. Still, the DM is limited in its ability to show drought at different time scales (short-term versus long-term) on one map (Heim, 2002). Key indicators include the PDSI, the Climate Prediction Center's soils moisture model (in percentiles), USGS weekly streamflow information (in percentiles), the SPI, and the Satellite Vegetation Health Index (National Drought Mitigation Center, 2003a). Other supplementary indices are those applicable during the growing season (such as the Crop Moisture Index) and during the winter months for western states when snow pack becomes an important component of available moisture in the hydrologic system. According to the DM, extreme and exceptional drought conditions were in effect across much of North Carolina during the latter part of August 2002 when the hydrologic conditions reached the lowest levels (fig. C-6). By May 2003, the DM indicated that no drought conditions were in effect for any part of North Carolina following the above-normal rainfalls in late August and September 2002. 


\section{Comparison of Precipitation Deficits with Deficits During Historical Droughts}

Assessments of drought conditions be identified using the available period of record for this location:

September 1949-June 1956, September 1965-July 1970, June 1984-April 1989, and May 1998-July 2002 (fig. 10;

table 2). Comparison of the precipitation deficits that occurred at Hickory during these four drought periods indicates that deficits during the 1998-2002 drought (68.3 inches, 51 months) were greater than those that occurred during the other droughts (fig. 10; table 2). In

generally include comparisons with conditions observed during historical droughts to aide in characterizing drought severity. By the early 1990s, seven major droughts of varying extent and severity had been documented in North Carolina: 1925-29, 1930-34, 1940-43, 1950-57, 1966-71, 1980-82, and 1985-88 (Zembrzuski and others, 1991). Comparison of precipitation deficits during the 1998-2002 drought with deficits for some of the historical droughts provides insight into how the recent drought ranks among the historical droughts. Data from 8 of the 13 NOAA precipitation stations selected for this report were used in comparing precipitation deficits during the historical and recent droughts-

7 stations have records dating back to the 1930s and 1940s, and 1 station (Mount Airy) has records prior to 1900 (table 2)

At Hickory, precipitation records began in January 1949, and four periods of prolonged drought conditions can
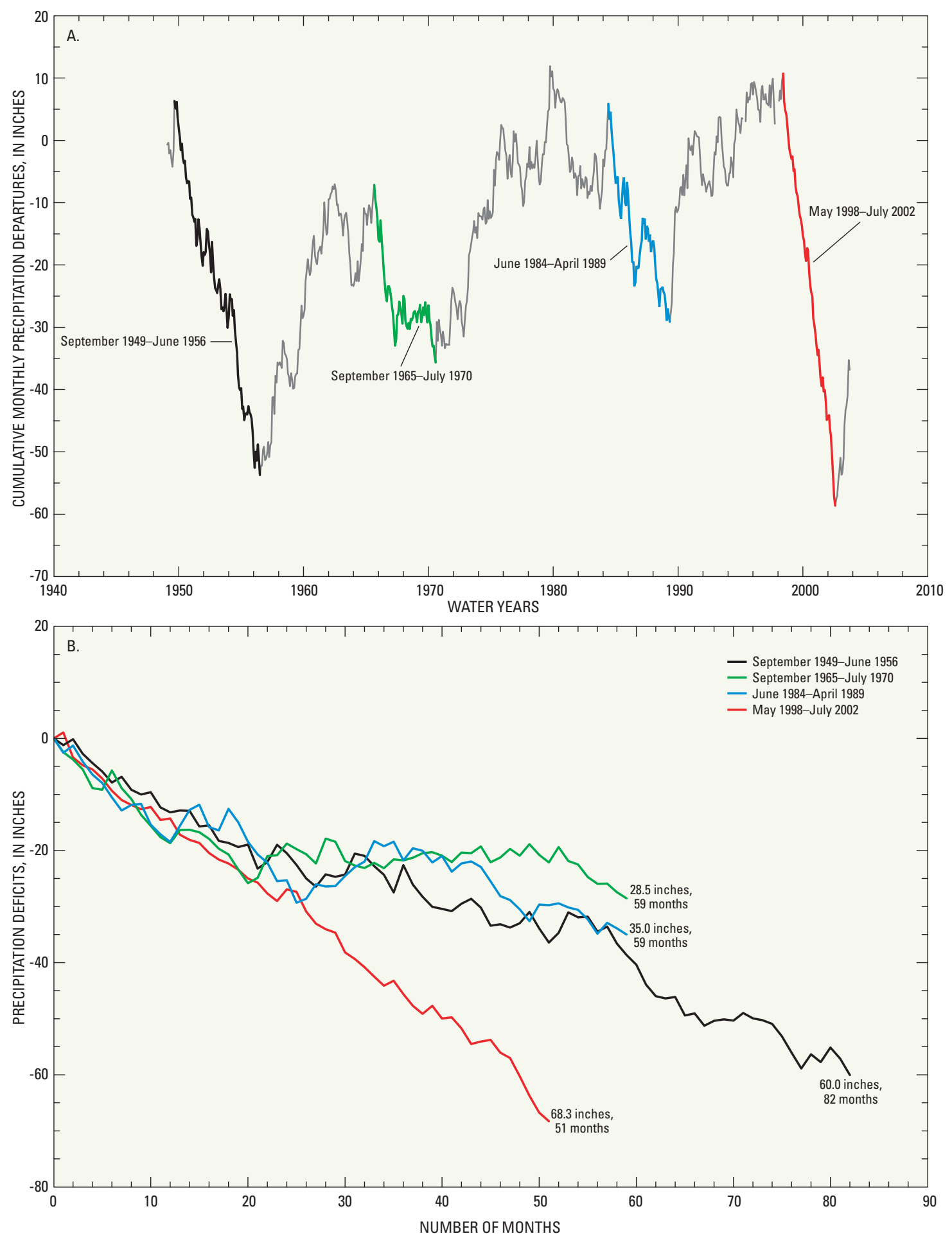

Figure 10. (A) Cumulative monthly precipitation departures and (B) precipitation deficits for selected historical droughts at the Hickory Regional Airport precipitation station in North Carolina, January 1949 through September 2003. 
Table 2. Precipitation deficits for selected historical droughts in North Carolina.

[NOAA, National Oceanic and Atmospheric Administration. Blue shading identifies droughts having the longest durations (in terms of elapsed time); brown shading identifies droughts with the highest rainfall deficits. Average annual precipitation and departures are based on monthly normal rainfall computed by using the 1971-2000 period of record as a reference. Stations are listed generally in west-to-east direction]

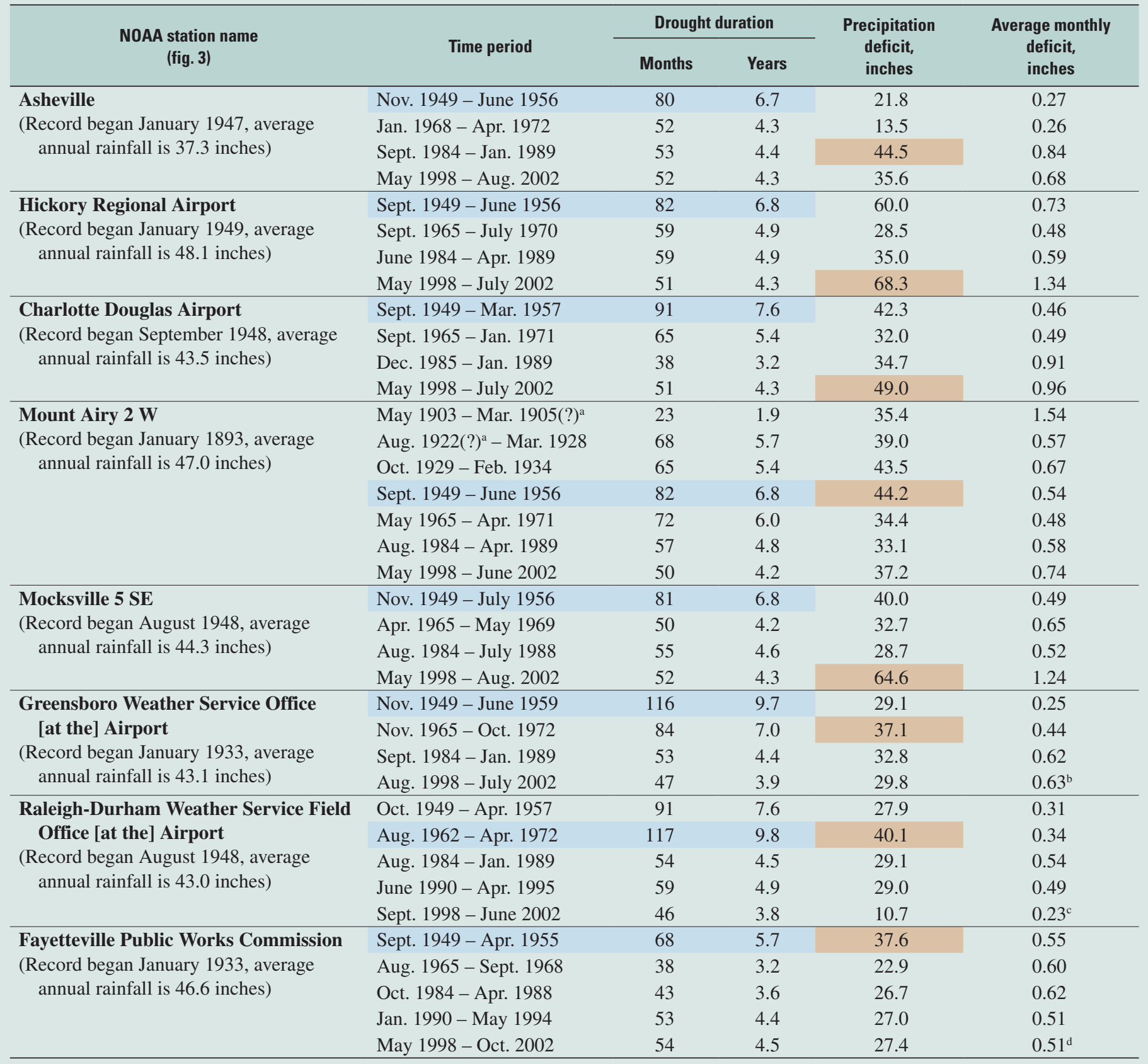

drought, rainfall deficit, and the average monthly deficit.

ginning and ending of

bPrecipitation deficit at Greensboro could have been about 35 inches (equivalent to about 0.74 inch per month) during the $1998-2002$ drought if rain associated with tropical storms in fall 1999 had not occurred. During September and October 1999, rainfall was 5.6 inches above normal.

'Precipitation deficit at Raleigh could have exceeded 25 inches (equivalent to more than 0.54 inch per month) during the $1998-2002$ drought if rain associated with tropical storms in fall 1999 had not occurred. During September and October 1999, rainfall was about 17 inches above normal.

dPrecipitation deficit at Fayetteville could have exceeded 40 inches (equivalent to more than 0.74 inch per month) during the $1988-2002$ drought if rain associated with tropical storms in fall 1999 had not occurred. During September and October 1999, rainfall was about 14 inches above normal. 
terms of precipitation, this comparison identifies the 1998-2002 drought as the most intense drought since the period of record began at Hickory. Precipitation deficits at Charlotte and Mocksville during the 1998-2002 drought also were greater than during previous drought periods identified for these locations (table 2). In addition, some of the previous drought periods at these three locations, particularly the 1950 s and 1960s droughts, were longer in duration than the 1998-2002 drought. The occurrence of relatively smaller deficits spread over longer periods of time during previous droughts suggests less severe conditions than those observed during the 1998-2002 drought.

At the Mount Airy station where records date from at least 1900, seven drought periods were noted (table 2), including three periods between 1900 and 1935 (fig. 11). The 1930s drought affected much of the United States, particularly the western states, and has been considered a benchmark drought for comparison with more recent drought conditions across the country. While comparisons for Hickory, Charlotte, and Mocksville identified the 1998-2002 drought as the most intense in terms of precipitation deficits, similar comparisons for Mount Airy provide a slightly different perspective. The precipitation deficit during the 1998-2002 drought was 37.2 inches over 50 months, which is not the most intense deficit documented at this precipitation station (fig. 11; table 2). During a 2-year period (1903-05) near the beginning of precipitation record, the deficit was about 35 inches. Although the deficit for the 1903-05 drought did not exceed that observed for 1998-2002, the shorter duration in which the deficit occurred suggests that conditions were apparently more intense at this location.

Because of variations in precipitation deficits and drought durations, an average monthly deficit was computed for each drought to serve as a quick and simple value for assessing the intensity of notable North Carolina droughts dur- ing the last 50 years (table 2). At three (Hickory, Charlotte, and Mocksville) of the eight stations, the average monthly deficit for the 1998-2002 drought exceeded the values computed for the other drought periods.

The 1998-2002 average monthly deficit at Greensboro barely exceeded the value for the 1984-89 drought (table 2). However, the 1998-2002 average monthly deficit at Raleigh and Fayetteville did not exceed values for previous droughts. The average monthly
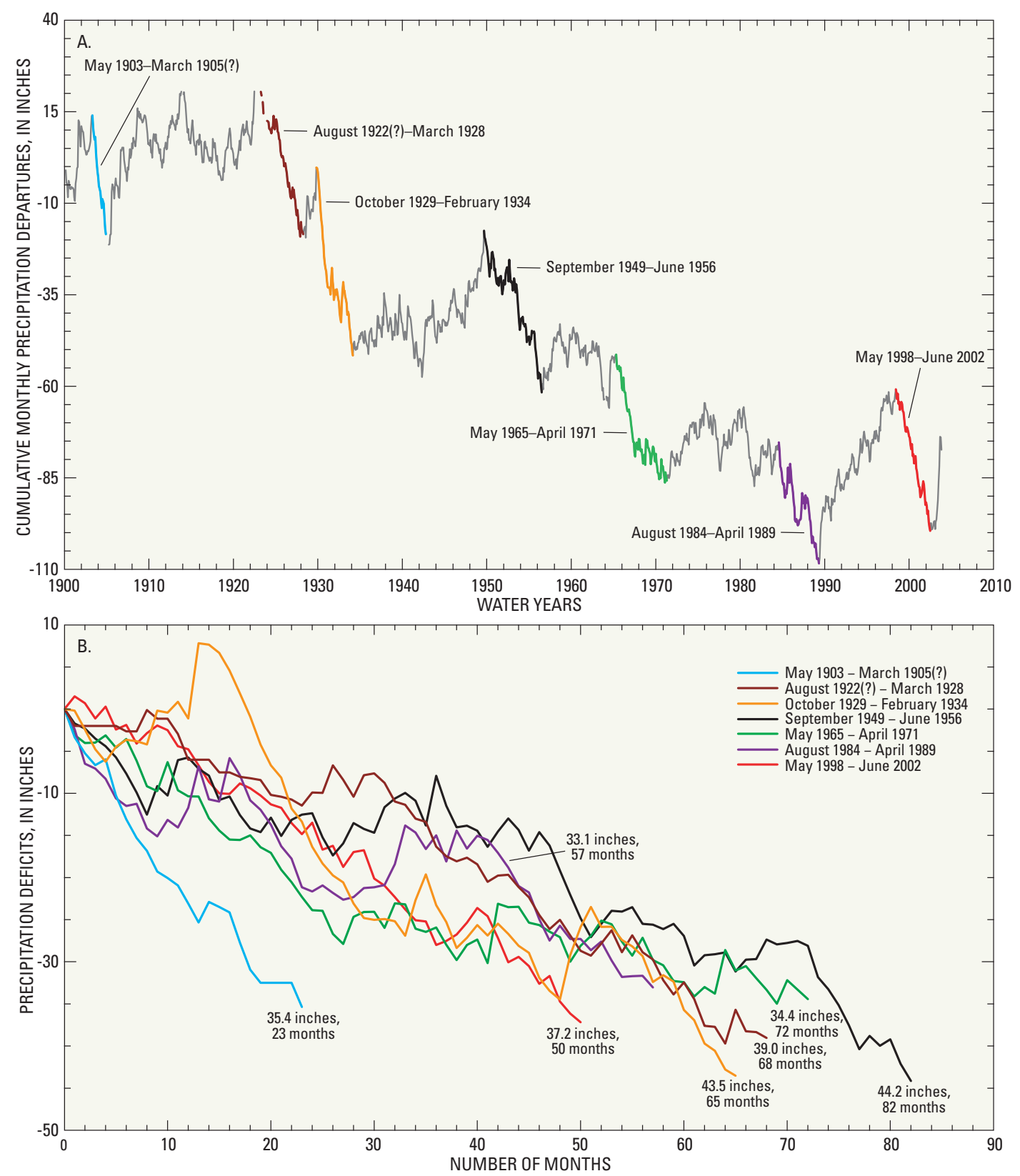

Figure 11. (A) Cumulative monthly precipitation departures and (B) precipitation deficits for selected historical droughts at the Mount Airy precipitation station in North Carolina, January 1900 through September 2003. 
deficits for the 1998-2002 drought at these three locations (Greensboro, Raleigh, Fayetteville) are skewed by rainfall from tropical storms (Hurricanes Dennis, Floyd, and Irene) in fall 1999. The occurrence of rainfall during these months had a moderate effect (5.6 inches above normal for September and October) on the deficit at Greensboro and larger effects on the deficits at Raleigh and Fayetteville. During September alone, rainfall amounts at Raleigh were 17.5 inches above normal. Similarly, during September and October, combined rainfall amounts were 14.0 inches above normal at Fayetteville (table 2; fig. 12).

Precipitation totals were adjusted to exclude the rainfall that occurred during August, September, and(or) October at Greensboro, Raleigh, and Fayetteville (table 2, see table footnotes). Adjusted average monthly deficits at these locations then became the highest among the drought periods identified. This confirms the fairly rapid return of drought conditions to the eastern Piedmont and Coastal Plain in the months immediately following the tropical storms. Exclusion of rainfall during these months suggests that the overall drought severity in the

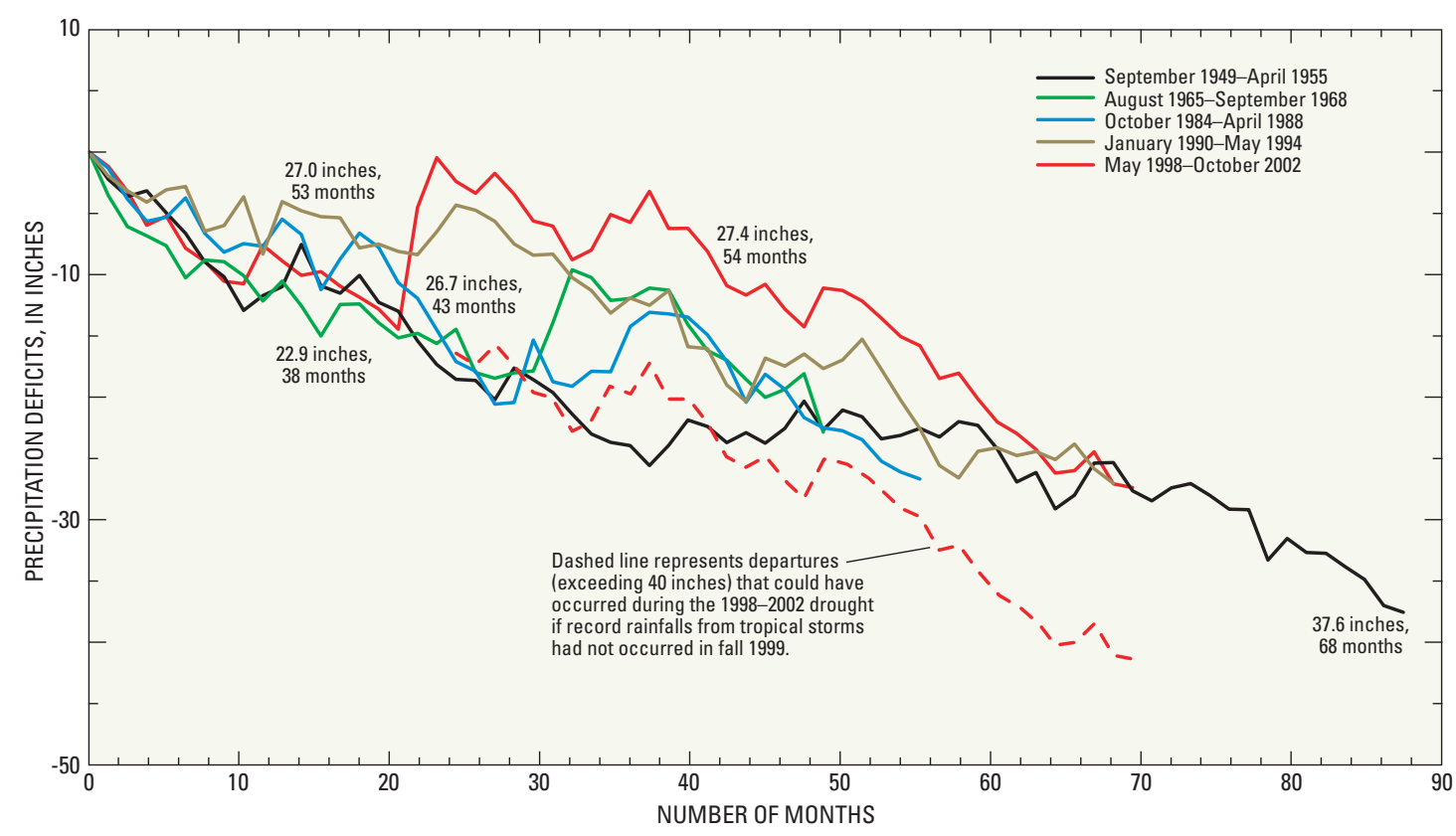

Figure 12. Precipitation deficits for selected historical droughts at the Fayetteville Public Works Commission precipitation station in North Carolina. eastern half of the State was similar to that observed in the western half.

\section{Hydrologic Conditions During the 1998-2002 Drought}

treamflow and ground-water
levels across North Carolina reached record lows at many locations during the 1998-2002 drought. In this section, hydrologic conditions observed at USGS data-collection sites during the 1998-2003 water years are described and compared to conditions at selected sites during periods of previous minimum records.

\section{Surface Water}

Of the 211 continuous-record streamgaging stations operated by the USGS during the 2002 water year (Ragland, Barker, and Robinson, 2003; Ragland, Walters, and others, 2003), record-low daily mean discharges were set at 121 sites during the 1998-2002 water years. Among these 121 gaging stations, record-low daily mean discharges were set at 94 sites during the 2002 water year alone, the year in which streamflow reached the lowest levels during the drought (fig. 13). In a similar manner, lowest annual mean discharge of record was set at 150 of the 211 gaging stations during the 1998-2002 water years, and records were set at 131 sites during the 2002 water year.

Not all of the 211 gaging stations, however, had long-term periods of record. By reassessing the periods of record among the 211 gaging stations, 150 sites were identified with systematic periods (total, including multiple subperiods) of record greater than 10 years through the 2002 water year. Among these 150 sites, record-low daily mean discharges were set at 65 sites during the 1998-2002 water years, and records were set at 55 of the 65 sites during the 2002 water year alone (fig. 13; tables 3, 4; p. 74).

Of the 150 sites having greater than 10 years of systematic record, 92 sites having greater than 30 years of uninterrupted record through the 2002 water year were identified for further analysis. These 92 sites were reassessed to identify streams not known to be affected by significant regulation and(or) diversions, which resulted in the selection of 68 sites for use in characterizing streamflow conditions (fig. 14). Percentiles of historical streamflows and frequency of 7 day average discharge for each calendar day were then computed for these 68 sites. For the purposes of characterizing streamflow conditions in smaller areas, the 68 sites were subdivided into 6 groups representing smaller areas of each physiographic province: 13 sites in the southern Blue Ridge, 11 sites in the northern Blue Ridge, 14 sites in the western Piedmont, 


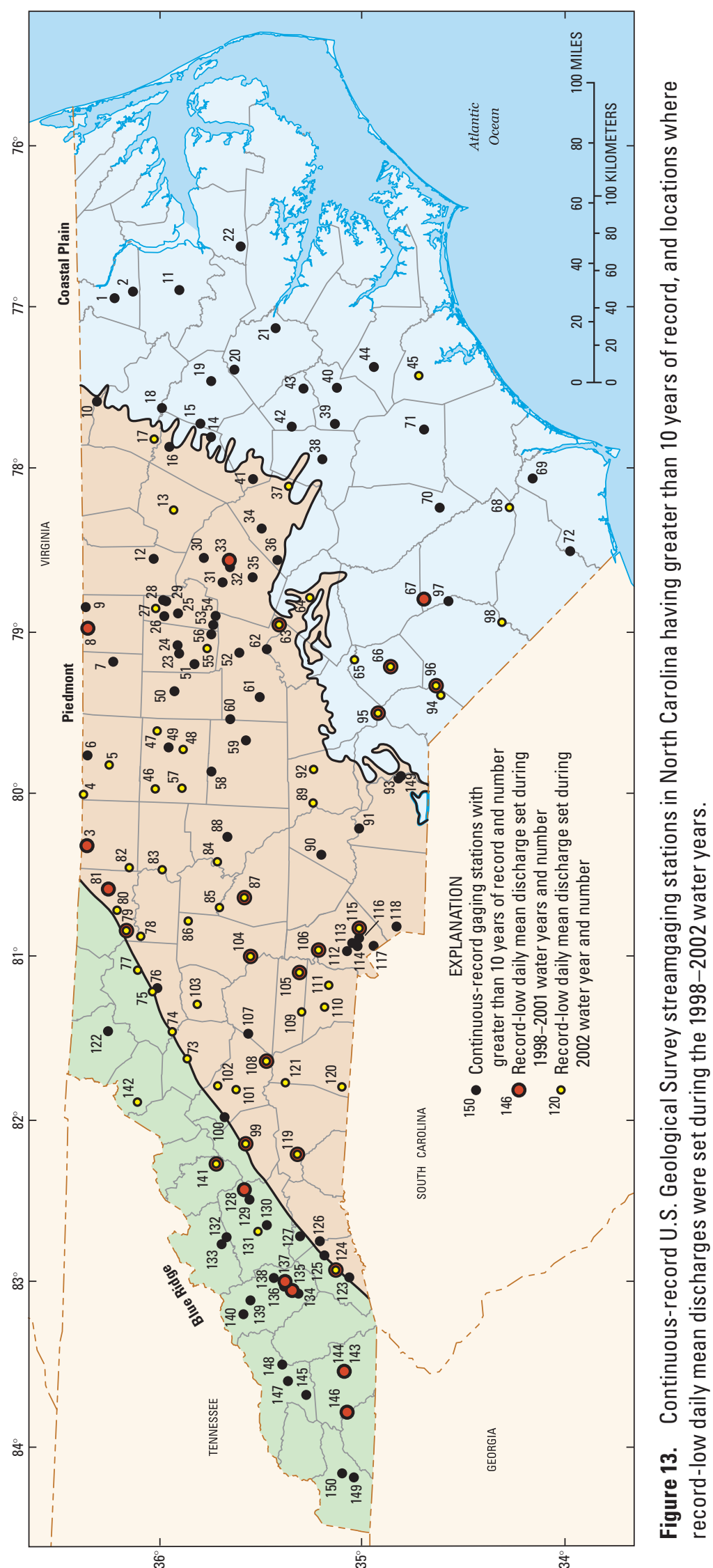




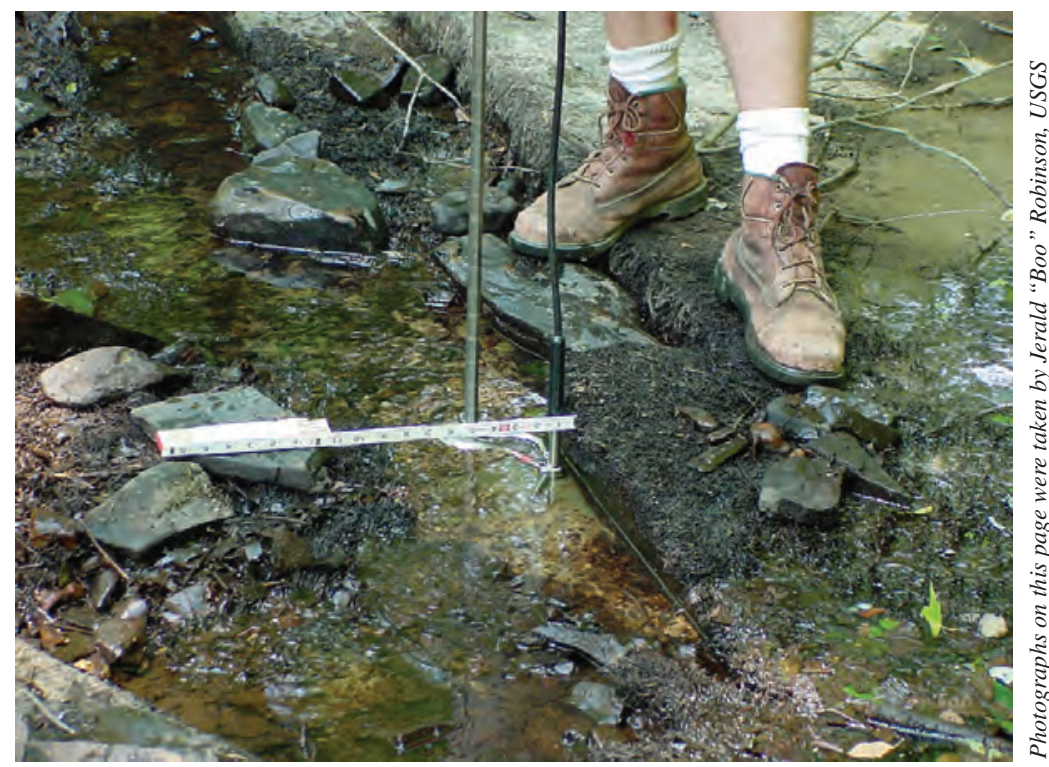

Streamflow measurement being made near USGS streamgaging station at Big Bear Creek near Richfield (site 90, table 4), June 19, 2002.

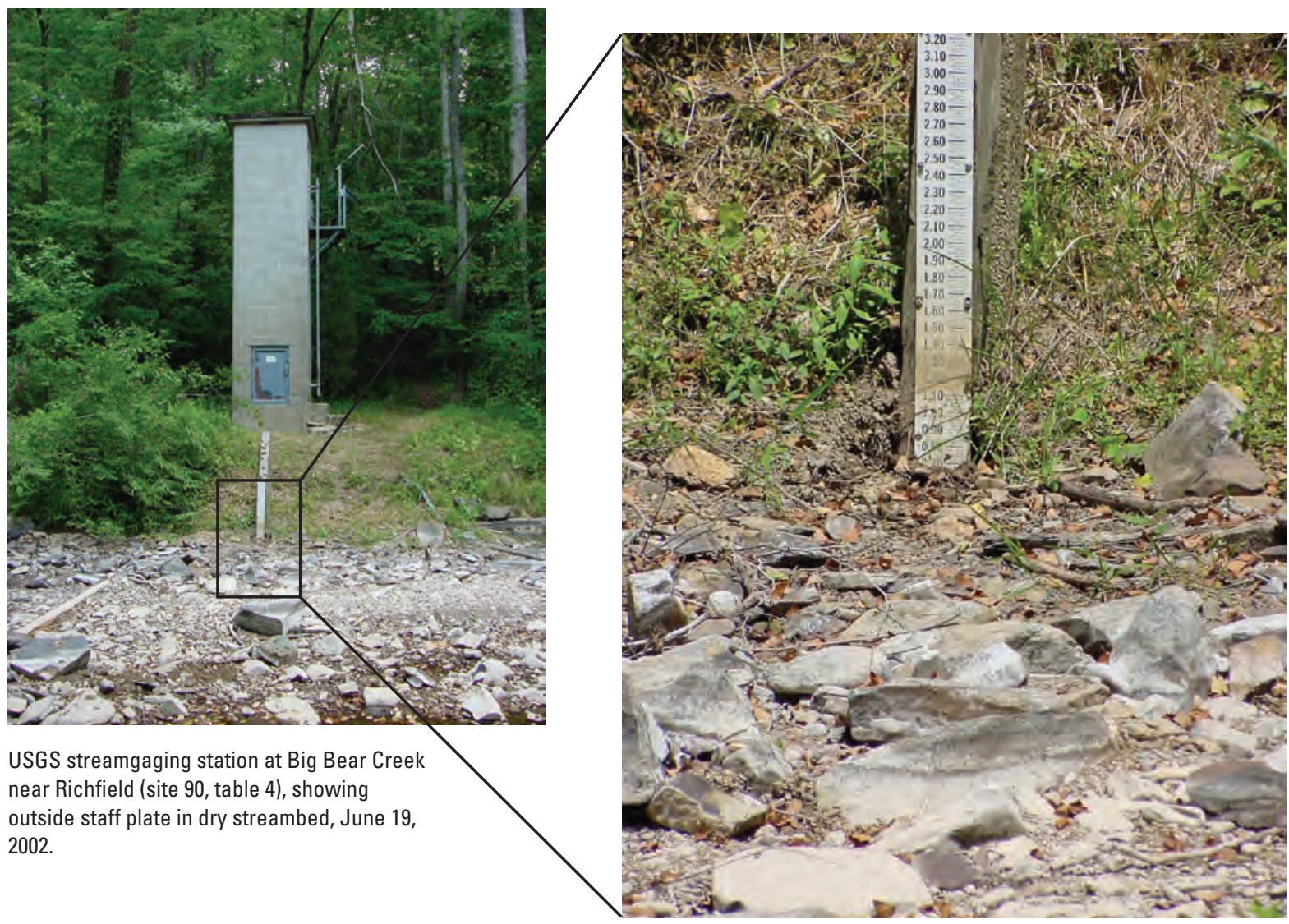


Table 3. Number of U.S. Geological Survey streamgaging stations in North Carolina where record-low discharges were set during the 19982002 water years.

[Based on assessment of 150 sites having greater than 10 years of systematic (or total) record through the 2002 water year]

\begin{tabular}{lcc}
\hline \multicolumn{1}{c}{ Discharge statistic } & $\begin{array}{c}\text { 1998-2002 } \\
\text { water years }\end{array}$ & $\begin{array}{c}\mathbf{2 0 0 2} \\
\text { water year } \\
\text { only }\end{array}$ \\
\hline Annual mean discharge & 94 & 86 \\
Seven-day average discharge & 74 & 61 \\
Daily mean discharge & $65^{\mathrm{a}}$ & 55 \\
Instantaneous discharge & 59 & 46 \\
\hline
\end{tabular}

${ }^{a}$ Figure 13 has two categories in which the occurrence of record-low daily mean discharge is shown: 1988-2001 water years ( 25 sites) and 2002 water year alone (55 sites). Fifteen of the 25 sites where records were set during 1998-2001 water years also were sites where records were set in the 2002 water year alone. Conversely, records were set at 10 sites during the 1998-2001 water years, but records were not set in the 2002 water year. Thus, when combined for the 4-year period, there were 65 unique sites having one or more record-low daily mean discharge.

19 sites in the eastern Piedmont, 7 sites in the southern Coastal Plain, and 4 sites in the northern Coastal Plain (fig. 14).

\section{Streamflow Conditions During the 1998-2003 Water Years}

Similar to the two contrasting precipitation patterns that occurred across much of North Carolina during the 1998 water year, streamflow conditions during the 1998 water year also were marked by two contrasting patterns. From October through December 1997, streamflows generally were in the high end of the normal range (defined as the 25th through 74th percentiles). Additional increases in streamflow were noted from January through April 1998, and above-normal conditions (75th to greater than or equal to $(\geq)$ 90th percentiles) were reported in all regions of the State. During this same period, about one-third of the index surface-water sites used for assessing monthly conditions were in the abovenormal range (Ragland and others, 1998). In February 1998, the highest monthly mean discharge for February was recorded at 13 sites, each of which has more than 35 years of record.

During May 1998, the first month in which rainfall amounts were below normal, streamflows began a gradual decline to levels in September that were in the low-normal range for Piedmont streams, with steeper declines (in the 10th-24th and less than $(<)$ 10th percentiles) for streams in the Blue Ridge Province. By September, streams in the southern Blue Ridge were at the lowest levels $(<10$ th percentile range) relative to other regions in the State. In terms of 7-day average discharges, streams in the Coastal Plain and Piedmont Provinces generally were in the 5- to 10-year recurrence intervals by September, and northern Blue Ridge streams were in the 10- to 20 -year range. The largest declines occurred in streams in the southern Blue Ridge Province where 7-day average discharges decreased to levels having 20- to 50-year recurrence intervals. During the 1998 water year, streams in the southern Blue Ridge generally had the highest number of days during which the 7-day average discharges exceeded the 10-, 50-, and 100-year recurrence intervals (figs. 15-17), and some sites

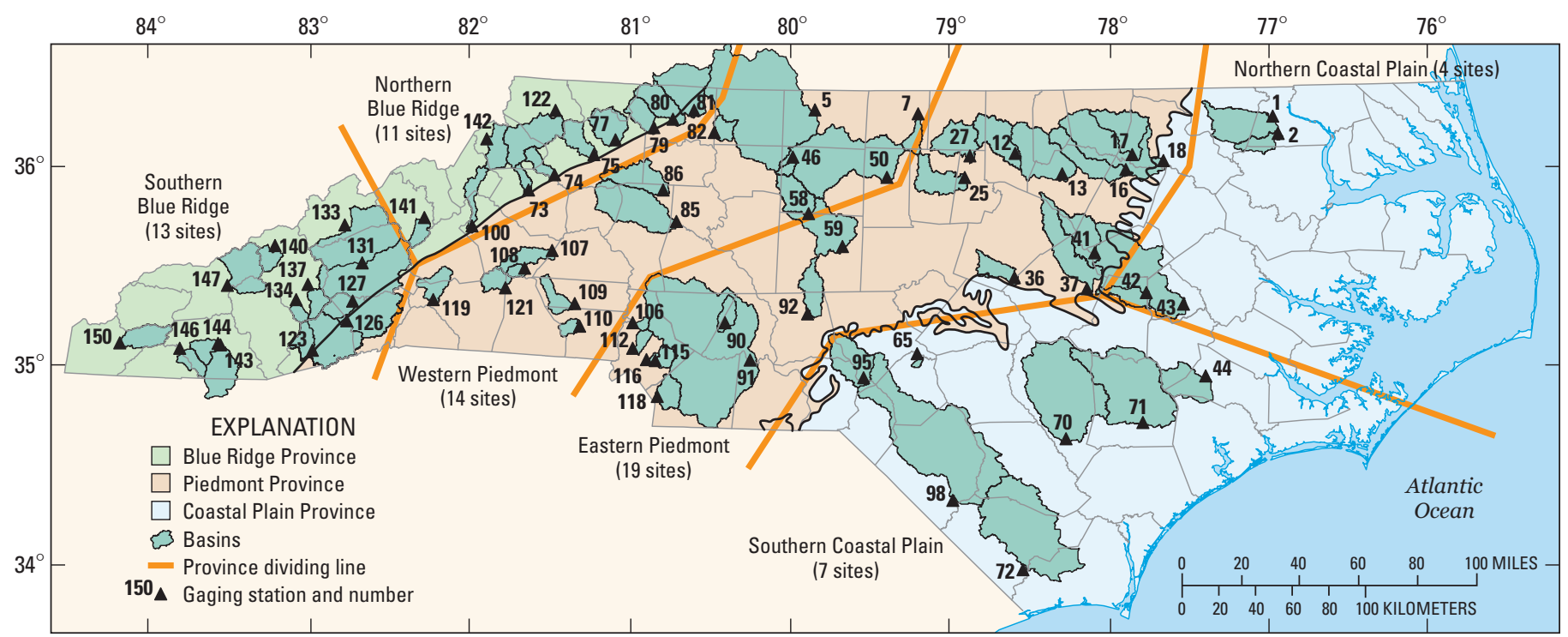

Figure 14. U.S. Geological Survey streamgaging stations (68 sites) used in the assessment of "daily" 7-day average discharges and historical streamflow percentiles for each calendar date during the 1988-2002 water years. 

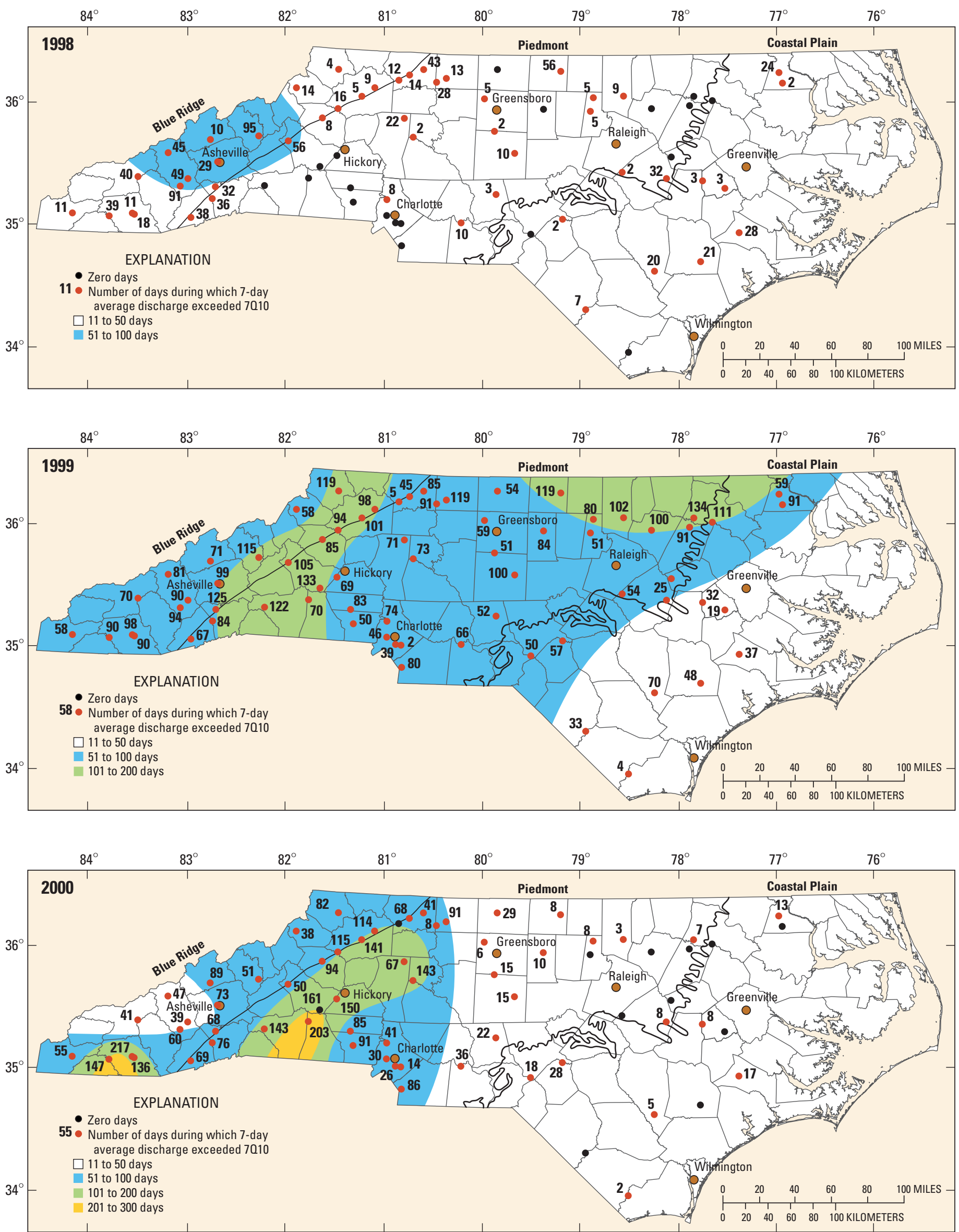

Figure 15. Generalized areas showing number of days in 1998-2003 water years during which 7-day average discharge exceeded the 7-day, 10-year low-flow discharge. 

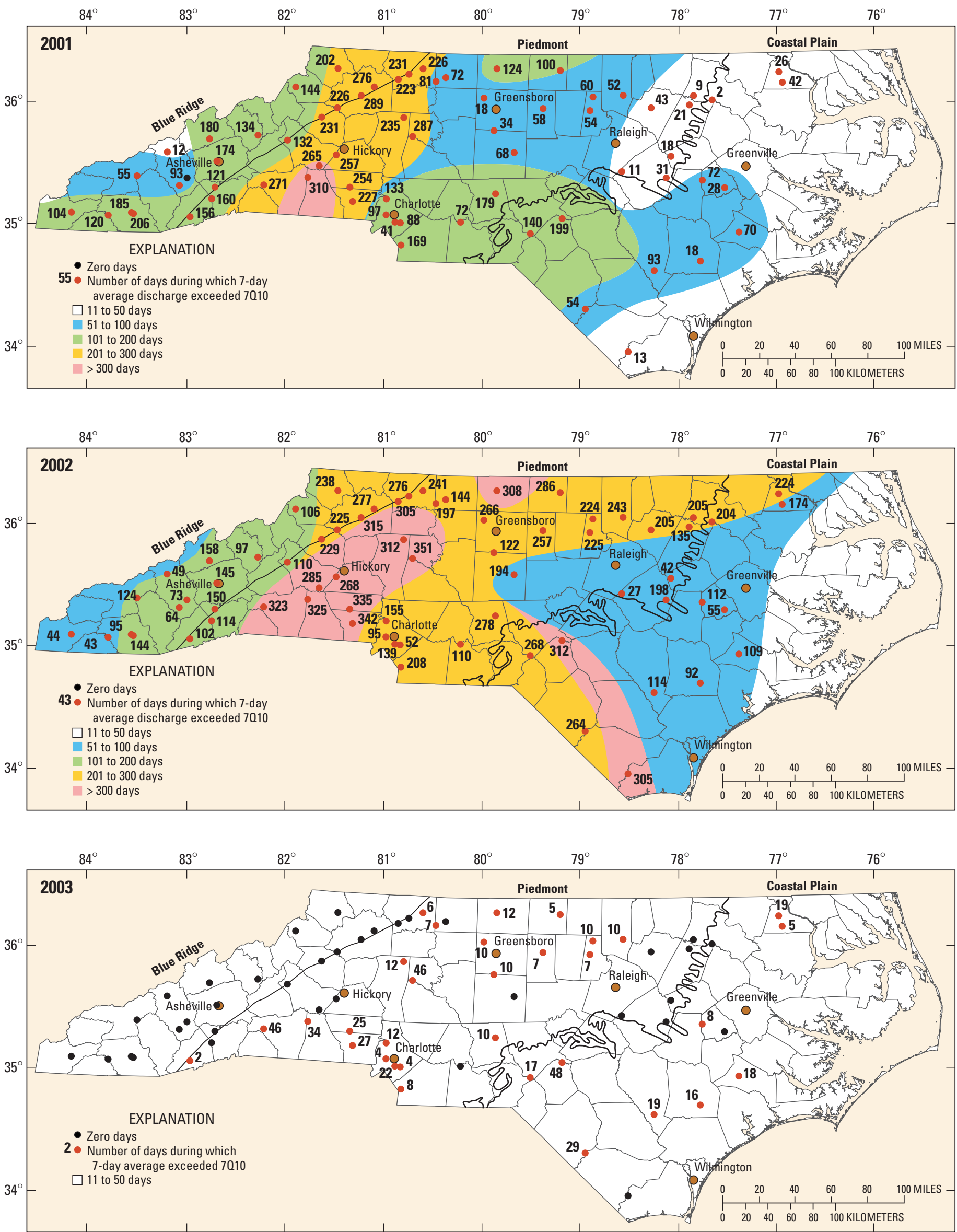

Figure 15. (Continued) Generalized areas showing number of days in 1998-2003 water years during which 7-day average discharge exceeded the 7-day, 10-year low-flow discharge. 

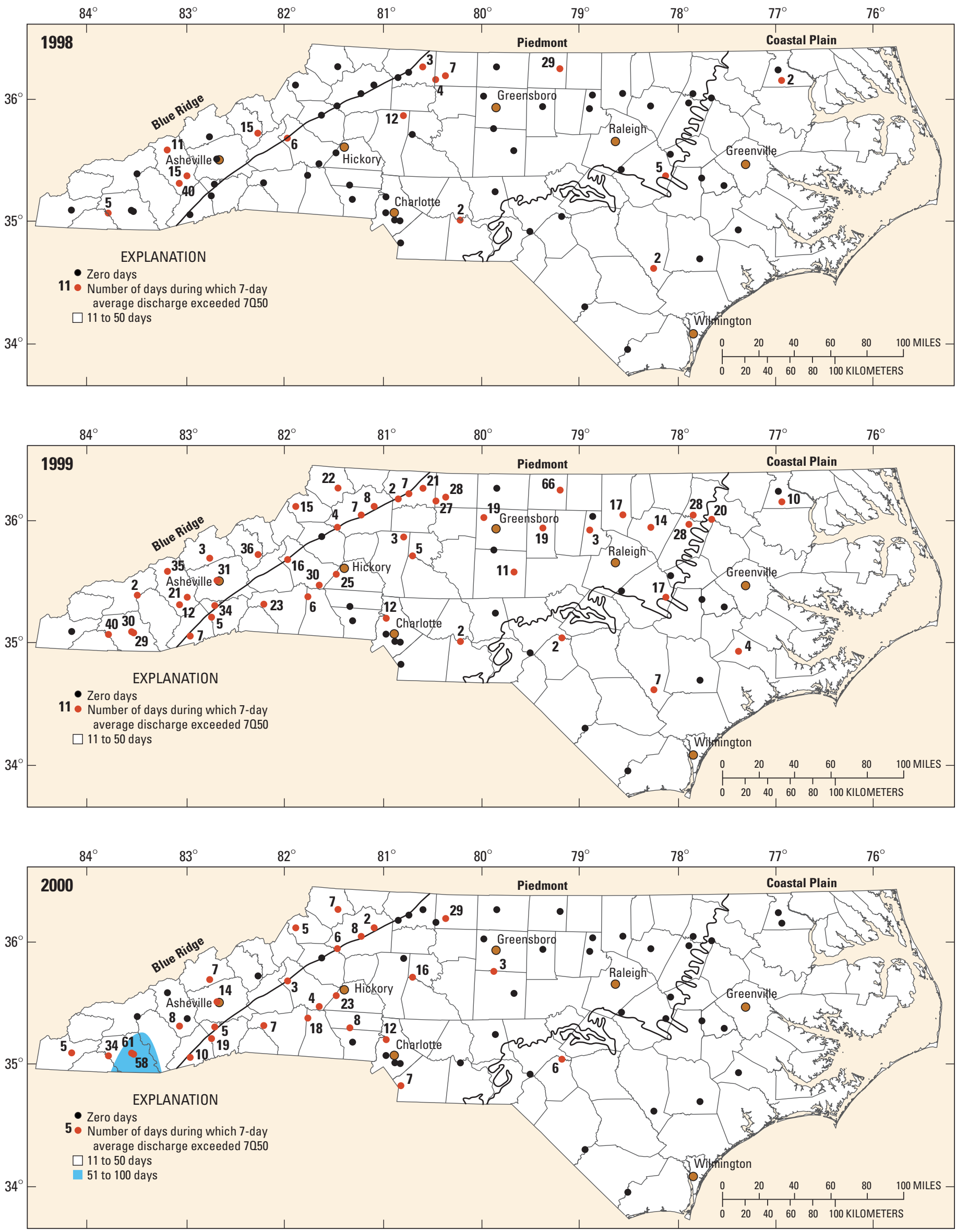

Figure 16. Generalized areas showing number of days in 1998-2003 water years during which 7-day average discharge exceeded the 7-day, 50-year low-flow discharge. 



Figure 16. (Continued) Generalized areas showing number of days in 1998-2003 water years during which 7-day average discharge exceeded the 7-day, 50-year low-flow discharge. 

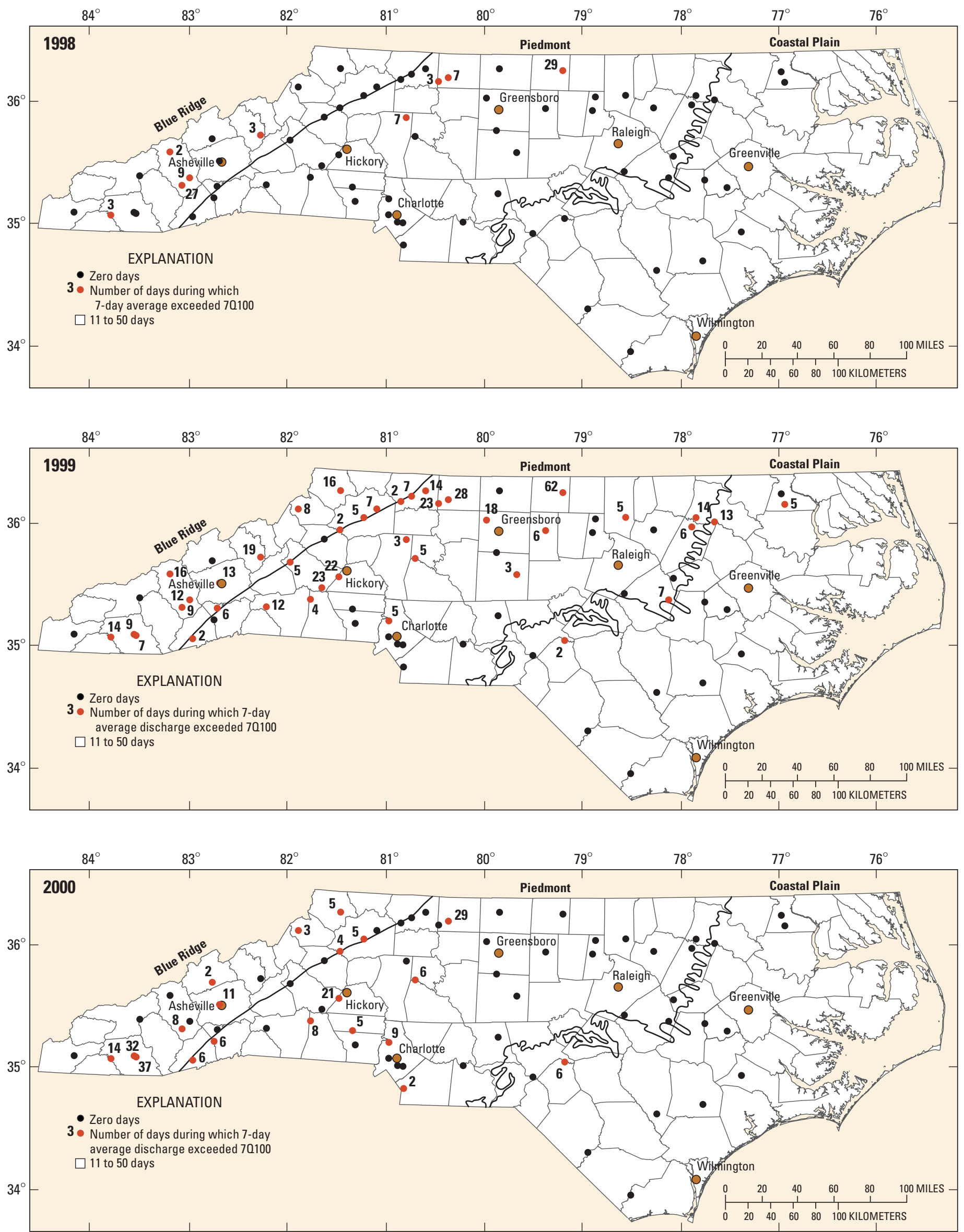

Figure 17. Generalized areas showing number of days in 1998-2003 water years during which 7-day average discharge exceeded the 7-day, 100-year low-flow discharge. 

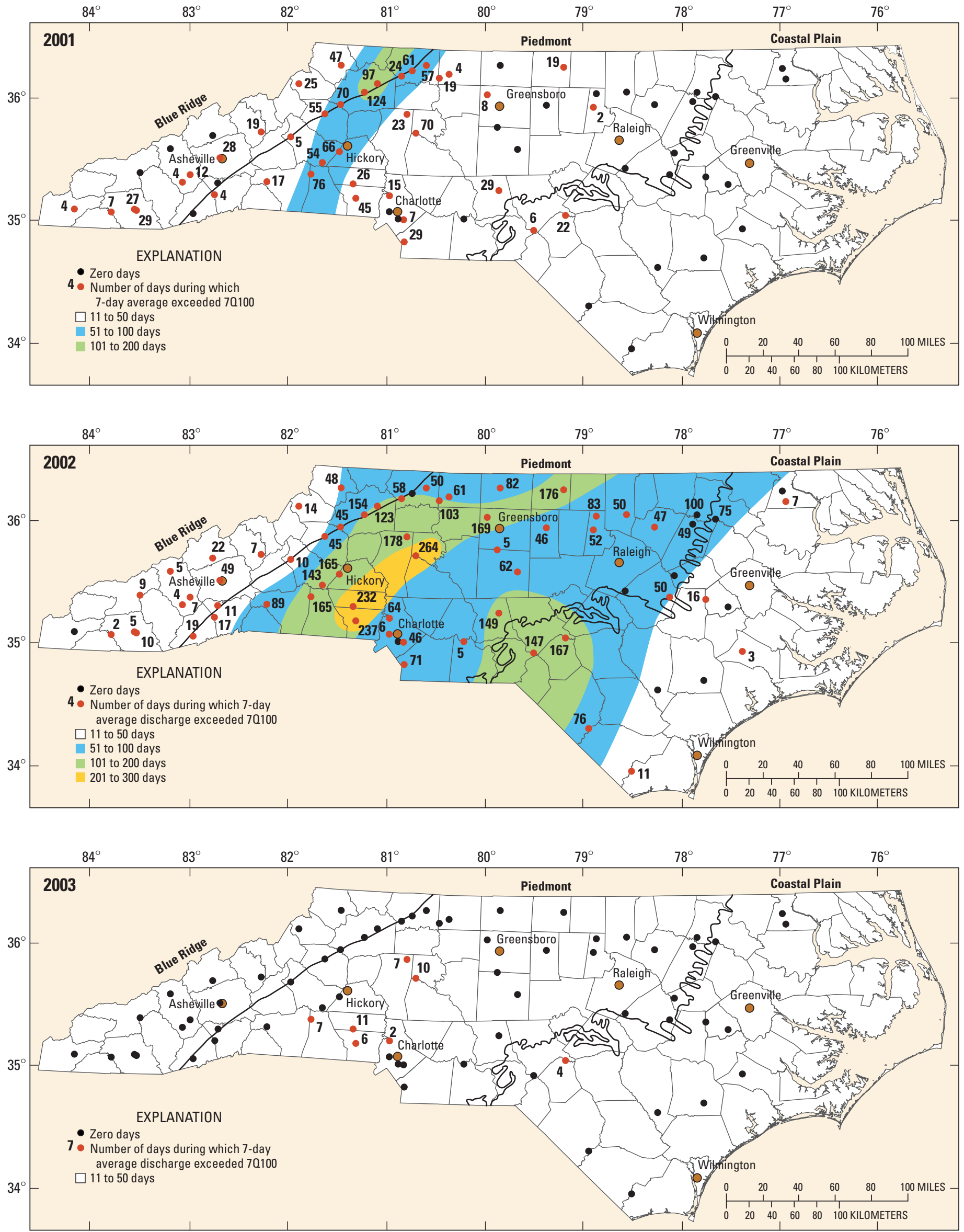

Figure 17. (Continued) Generalized areas showing number of days in 1998-2003 water years during which 7-day average discharge exceeded the 7-day, 100-year low-flow discharge. 
exceeded 10-year intervals for more than 50 days. Below-normal rainfall in some areas of the southern Blue Ridge from October 1997 through March 1998 also contributed to the low streamflow levels during the latter half of the 1998 water year. Although streams declined in other regions of the State during May through September 1998, declines generally were less because of above-normal rainfall that occurred during the first half of the water year.

New record-low daily mean discharges were set at six gaging stations during the 1998 water year. Four of these sites $(128,135,137$, and 141) were in the Blue Ridge Province, and two sites $(8,105)$ were in the Piedmont Province (fig. 13). With the exception of site 8, records were set during September 1998. The record-low daily mean discharge set at Hyco River below Afterbay Dam near McGehees Mill (site 8) occurred in November 1997 prior to the start of the drought (table 4) and was a result of changes in flow releases from the upstream dam. The second Piedmont site (105) in southeastern Lincoln County only has records dating from October 1990. Similar to site 105 , two of the Blue Ridge sites (128, 135) have relatively short periods of record dating from the late 1980s. The periods of record at sites 137 and 141 date from the mid-1950s, but new record-low daily mean discharges slightly eclipsed the previous records in effect before the 1998 water year.

Examination of overall streamflow trends for the 1999 water year revealed that while no significant declines were noted in the flows, no significant improvements occurred. It was a period in which the drought was punctuated by brief periods of improvements in the hydrologic conditions. Also, streams in the eastern Piedmont and Coastal
Plain increased significantly as a result of flooding from tropical storms in late August and September. Overall streamflow conditions during much of the 1999 water year were in the lower ranges of normal and the 10th-24th percentiles. Some improvements in streamflows occurred during the winter months, which appeared to have kept overall conditions in the spring and summer from serious declines. However, streamflows in the Blue Ridge and western Piedmont declined to levels in the 10th-24th and $<10$ th percentiles by September 1999, while streams in the eastern Piedmont and Coastal Plain were in the high percentile ranges ( $>90$ th percentile) in response to the tropical storms. In terms of 7-day average discharges, streams across the State were typically in the 5- to 20-year recurrence interval range for much of the year. However, some streams in the Blue Ridge Province decreased to levels having 50-year-plus
Record-low daily mean discharges were set at 16 gaging stations, mostly during August and September 1999. About two-thirds of these sites were in the western Piedmont and Blue Ridge Provinces. Six of the sites $(33,63,66$, 67, 95, and 96) were in the eastern Piedmont and Sand Hills region of the southern Coastal Plain (fig. 13), and the record-low daily mean discharges occurred at these sites in mid-August just prior to the tropical storms that brought a reprieve from the drought conditions in the eastern half of the State. The increased number and spatial distribution of record-setting sites indicated the drought's widening effects on the hydrologic conditions in most areas of the State. Two sites (105, 141; fig. 13) also had record-low daily mean discharges in the 1998 water year.

Overall streamflow conditions during the 2000 water year again revealed differences in conditions

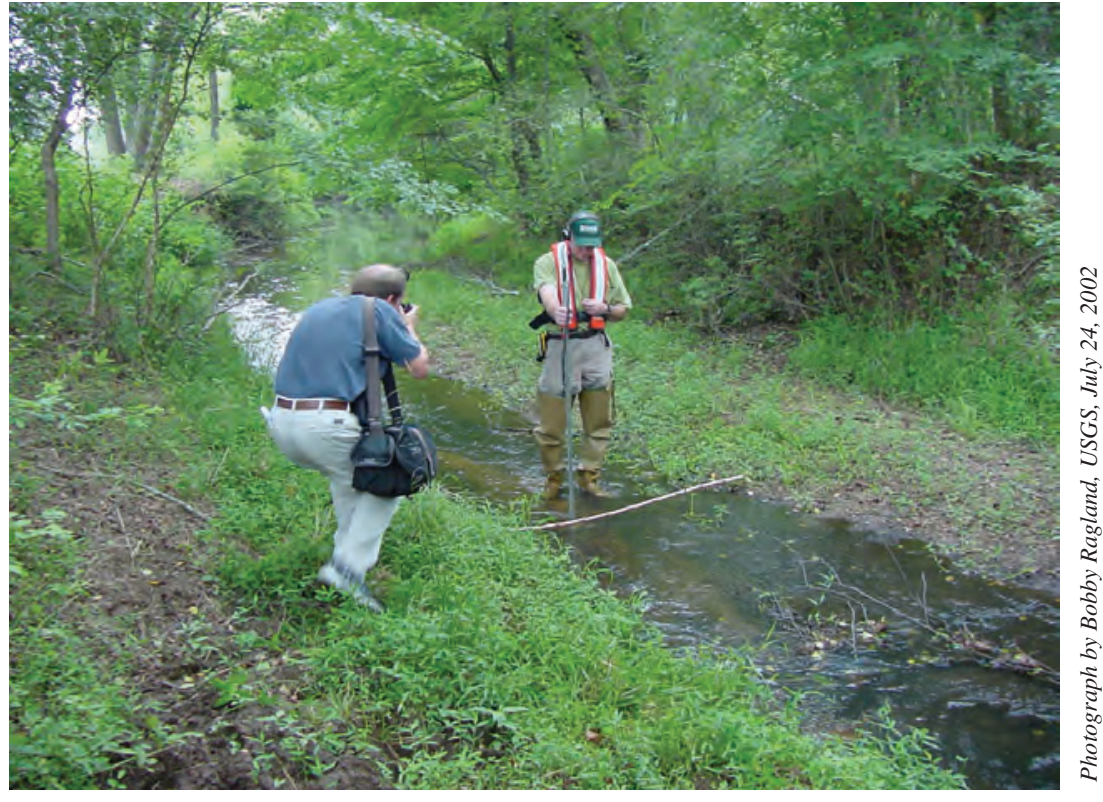

USGS hydrologist makes streamflow measurement as a media photographer captures the activity.

between the western and eastern halves of the State. During the first half of the 2000 water year, the Coastal Plain and eastern Piedmont streams gradually declined from the above-normal range (75th percentiles and higher) to the low-normal range following the flooding that occurred from Hurricane Floyd. In the western Piedmont and Blue Ridge Provinces, streams generally were between the low-normal

recurrence intervals. Among the 68 sites analyzed, about 15 sites across the State had more than 100 days in which 7-day average discharges were in the $>10$-year recurrence interval range (fig. 15).

Likewise, the number of days in which 7-day average discharges exceeded the 50- and 100-year recurrence intervals increased significantly during the 1999 water year (figs. 16, 17). range and the 10th-24th percentiles throughout most of the 2000 water year. Seven-day average discharges in the eastern Piedmont and Coastal Plain were at levels having 5- to 10-year recurrence intervals throughout most of the 2000 water year. By comparison, 7-day average discharges in western North Carolina varied between 10- and 
20-year recurrence intervals, declining further to 50-year-plus recurrence intervals during the early spring and mid-summer months. In the western Piedmont and Blue Ridge Provinces, 10 gaging stations recorded more than 100 days in which 7-day average discharges were at $>10$-year recurrence intervals (fig. 15). Compared to about 15 sites in the 1999 water year that had recurrence intervals for more than 100 days, one might suspect that drought conditions had improved between the two periods. While the tropical storms late in the 1999 water year reduced the number of days in which 7-day streamflow conditions exceeded the various recurrence intervals in eastern North Carolina, the drought strengthened its hold in western North Carolina, as indicated by two gaging stations with 7-day average discharges exceeding the 10-year recurrence interval on more than 200 days (fig. 15). Further, the 7-day average discharges exceeded the 50-year intervals on more than 50 days during the 2000 water year at one site in the southern Blue Ridge (fig. 16). These patterns confirm that the continuing declines in streamflow conditions during the 1999 and 2000 water years were tempered briefly in eastern areas of the State but not in the western areas.

New record-low daily mean discharges were set during the 2000 water year in the latter part of August at three gaging stations-sites 87 and 104 in the western Piedmont and site 143 in the Blue Ridge Province (fig. 13). The new record at site 143 eclipsed the previous record that was set in the 1999 water year. The decreased number of sites where records were set in the 2000 water year, compared to the previous year, apparently was a result of temporary improvements in precipitation patterns. Although improved precipitation patterns were not sufficient to alleviate the drought, streamflow conditions were just above previously set record levels in many areas of North Carolina.

Throughout much of the 2001 water year, overall streamflows were more consistently below normal $(<10$ th and 10th-24th percentiles) in all three provinces of the State. However, the

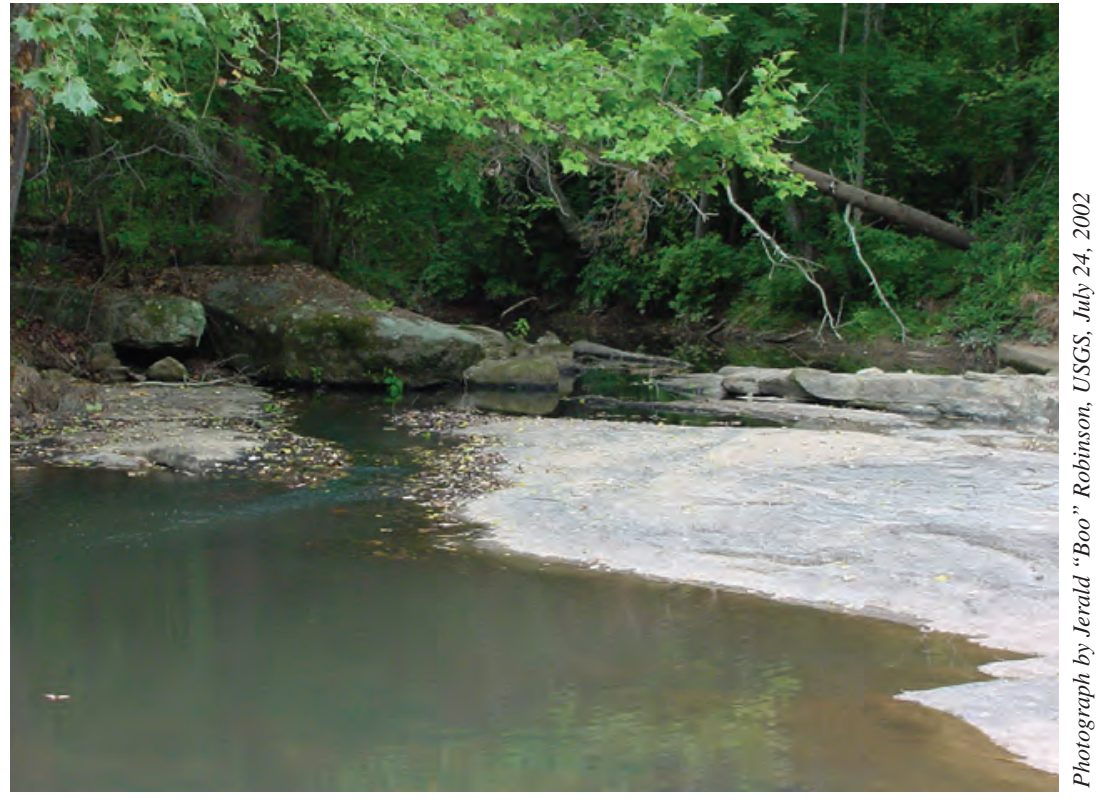

Downstream from the USGS streamgaging station at Long Creek near Bessemer City, N.C., (site 110 , table 4), daily mean discharge was $0.33 \mathrm{ft}^{3} / \mathrm{s}$ on July 24,2002 . Median streamflow for July 24 at the site is $11 \mathrm{ft}^{3} / \mathrm{s}$.

7-day average discharges at streams in the three provinces were at varied recurrence intervals during the year. The number of days in which 7-day average discharges exceeded the 10-, 50-, and 100-year recurrence intervals continued to increase significantly in the Blue Ridge and western Piedmont. In particular, the 7-day average discharges exceeded the 10-year recurrence interval at about 15 sites in this area for more than 200 days and at 1 site for more than 300 days (fig. 15). An increased number of days also occurred in the eastern areas of the State where the effects of previous years' tropical storms had diminished (fig. 15). Of important note are the 50- to 100-year recurrence intervals that occurred at streams in the western Piedmont and northern Blue Ridge Provinces during the winter (figs. 16, 17). The winter and early spring months (December through March) typically are a time of recharge for hydrologic systems, allowing water levels in streams and ground water to be replenished following the growing season. The very low flows that occurred during the winter resulted in further declines in the hydrologic system during the 2001 growing season, particularly in the western Piedmont and Blue Ridge Provinces.

New record-low daily mean discharges were set at six gaging stations in the western Piedmont during the 2001 water year. Discharge records at three of the sites $(87,104$, and 105) surpassed the previous records set during the 1998-2000 water years. The occurrence of consecutive records being set was an indication of the drought's intensifying effects and the relatively short periods of record (less than 25 years) at these sites. Including the sites where record-low flows were established consecutively (during the 1998-2000 water years), record-low daily mean discharges had been set at 19 gaging stations by end of the 2001 water year.

Streamflow conditions continued to decline during the 2002 water year and by August and September reached the lowest levels since the beginning of the drought. Across most of North Carolina, flows consistently were in the $<10$ th percentile range and new record-low flows (for the calendar days) were being set on an almost daily basis. Recurrence intervals for 7-day average discharges were varied across the State, and many streams were in the 50- to 100-year recurrence interval ranges during the 
summer until abundant rainfalls in September began to reverse the low-flow trends. During the 2002 water year, the areal extent of sites where 7-day average discharges exceeded the 10-year recurrence interval for more than 200 and 300 days covered much of central North Carolina (fig. 15). In the western Piedmont, 7-day average discharges exceeded the 50-year and 100-year intervals on more than 200 days at six and three gaging stations, respectively (figs. 16, 17). At most of the sites where lowest daily mean discharges were set during the drought, record-low flows were observed repeatedly during the 2002 water year. For example, observed daily mean discharges at Reedy Fork near Oak Ridge (site 46, fig. 13; table 4) in Guilford County were at or below the previous record-low daily mean discharge (1.7 cubic feet per second $\left(\mathrm{ft}^{3} / \mathrm{s}\right)$, set on August 7, 1977) 16 times from mid-June through mid-August 2002. The new record-low daily mean discharge for this site is $0.61 \mathrm{ft}^{3} / \mathrm{s}$, set on August 14, 2002. Similar patterns of multiple record-low daily mean discharges were observed at numerous other gaging stations. At 17 gaging stations, more than 10 record-low daily mean discharges occurred during the 2002 water year. The maximum number of multiple records was at Jacob Fork at Ramsey (site 108, fig. 13; table 4) in Burke County, where observed daily mean discharges were at or below the previous record-low daily mean discharge $\left(3.7 \mathrm{ft}^{3} / \mathrm{s}\right.$, set on August 19, 1999) 20 times from mid-June through mid-August 2002. The new record-low daily mean discharge for this site is $0.87 \mathrm{ft}^{3} / \mathrm{s}$, set on August 13, 2002. Prior to the 1998 water year, the record-low daily mean discharge for Jacob Fork was $4.7 \mathrm{ft}^{3} / \mathrm{s}$, set on August 27, 1988 (table 4), which is an example of repeatedly new record-low discharges being set at some gaging stations during the 2002 water year and throughout the drought.

The 4-year drought, including two consecutive winters of below-normal precipitation in 2001 and 2002, resulted

\section{Record minimum flow was measured in September 2002 at the French Broad River at Asheville where continuous measurements have been recorded since October 1895.}

in record-low daily mean discharges being set at many sites during the 2002 water year alone. New record-low daily mean discharges were set at 55 gaging stations, primarily during a 6-week period between early August and midSeptember 2002. New records were set at gaging stations across North Carolina except in the northeastern Coastal Plain; however, most of the new records were set at sites in the western Piedmont and Blue Ridge Provinces. Of the 55 sites where record-low daily mean discharges were set during the 2002 water year, new records at 25 sites also were set previously during the 1998-2001 water years (fig. 13).

In fall 2002, streamflows began to continuously increase at many sites across North Carolina for the first time in nearly 4 years. During October 2002 through June 2003, many streams returned to above-normal levels (75th-89th percentiles). Following a brief decline during January, streamflow conditions continued to improve to higher levels between February and June, and levels consistently were in the 75 th-89th percentile range and $>90$ th percentile. Seven-day average discharge increased significantly to levels consistently having 2- to 5-year recurrence intervals during October through December 2002. In fact, none of the 68 sites used in this analysis had more than 50 days in which the 7-day average discharges exceeded the 10-, 50-, or 100-year recurrence intervals during the 2003 water year (figs. 15-17), a complete reversal of the patterns observed during the 2001 and 2002 water years. In terms of streamflow, drought conditions were considered nonexistent by the end of April 2003.
As an example of the rapid reversal in streamflow conditions between the 2002 and 2003 water years, the highest annual mean discharge for the periods of record was set at 130 of 214 continuous-record gaging stations across North Carolina (Ragland, Barker, and Robinson, 2004; Ragland, Walters, and others, 2004). Further, 87 sites where the new record highs were set also had record low annual mean discharges during the 2002 water year, including 19 of the 68 gaging stations analyzed for this report.

\section{Comparison of Streamflow During 1998-2002 with Historical Droughts}

Comparisons of minimum 7-day average discharges for six selected gaging stations (two from each physiographic province) with long-term records provided insight into how the 1998-2002 drought compares with historical droughts in North Carolina (table 5; fig. 18). The minimum 7-day average discharge was determined for each drought period (table 5).

At three of the sites $(131,85$, and 27), which are in the Blue Ridge and Piedmont Provinces, the minimum 7 -day average discharges during the 1998-2002 drought became the minimum flows for the periods of record, including site 131 (French Broad River at Asheville), which has the longest period of streamflow record in North Carolina. Measured continuously since October 1895, the flow conditions in the French Broad River reached the lowest level of record in September 2002, surpassing the previous minimum established in August 1925 (table 5). The minimum 7-day average discharge set during the 1998-2002 drought at site 122 (South Fork New River near Jefferson), also in the Blue Ridge Province, did not surpass the period of record minimum (set in 1925) but was the second lowest flow in terms of minimums set during drought periods (table 5). At the two Coastal Plain 


\section{Characterizing Low-Flow Frequency: Can Droughts Change the 7Q10 Discharge?}

The characterization of low flow or flood flow is one of the primary objectives for monitoring streamflow in North Carolina and throughout the United States. Information derived from frequency analysis is used in the planning and management of water resources and affects decisions about issues ranging from water-quality management to the engineering design of bridges and drainage structures. When changes in surface-water conditions are extreme, as in long-term droughts or major flooding events, questions commonly are raised about how the observed conditions compare to frequency statistics and how sensitive existing statistics may be to extreme flow events.

Streamflow frequency statistics are discharge values that have an associated probability of occurrence, generally referred to as the recurrence interval and expressed in years (sometimes called the return period). The recurrence interval of a given high-flow or low-flow discharge represents the probability that the discharge will be equaled or exceeded in any given year (Bales and others, 2000). The concept of exceedance in frequency analysis does not imply that an observed streamflow value will always be numerically higher, but rather exceeded during an event in terms of frequency of occurrence of extreme historical observations (higher flows during high-flow events and lower flows during low-flow events).

For high-flow events, frequency analysis is conducted by using a record of peak discharges for a given period or season, most commonly an annual period. For example, if the annual peak streamflow having a 100 year recurrence interval is $10,000 \mathrm{ft}^{3} / \mathrm{s}$, the annual peak streamflow would be equal to or higher than the 100-year peak streamflow, on average, one time in 100 years. Stated another way, the probability is 1 percent (the inverse of the recurrence interval) in any given year that the annual peak streamflow will be equal to or higher than the 100 -year peak streamflow.

Low-flow frequency analysis, however, is conducted by using the lowest average flow for a specified number of days. The most common low-flow frequency statistic is the 7-day, 10-year low-flow (7010) discharge. The annual minimum average streamflow for a 7-consecutive-day period will be at or below the 7010 discharge, on average, one time in 10 years (Weaver and Fine, 2003). If the 7010 discharge is $5 \mathrm{ft}^{3} / \mathrm{s}$, for example, then the annual minimum average streamflow for a 7-consecutive-day period would be $5 \mathrm{ft}^{3} / \mathrm{s}$ or lower, on average, 1 time in 10 years, 5 times in 50 years, or 10 times in 100 years. $A$ recurrence interval of 10 years implies that the annual minimum average streamflow for a 7-consecutive-day period will be greater than the 7010 discharge in 9 of 10 years, on average. In any given year, the probability that the minimum average streamflow for a 7 -consecutive-day period will be less than the 7010 is 10 percent (the inverse of the recurrence interval).

Other variations of low-flow statistics are the 7050 and 70100 discharges, which are the annual minimum average streamflows for a 7-consecutive-day period that would be expected, on average, one time in 50 years and 100 years, respectively. While most low-flow statistics are based on analyses of annual minimum values, low-flow frequency analyse can be conducted for minimum values for a month, season, or calendar date (for example, the lowest 7-day average discharge on June 30). Analyses of 7-day average discharge ending on each calendar date were conducted for this report to determine the "daily" 7010, 7050, and 70100 discharges at gaging stations across the State (see "Streamflow Conditions During the 1998-2003 Water Years;" figs. 15-17).

An understanding of frequency concepts includes the awareness that such statistics can be exceeded in consecutive years or even within a given year, not just one time during the stated return period. For example, it is possible that measured flow conditions can exceed the 100-year peak discharge in consecutive years, or even within the same year. Likewise during low-flow events, it is possible that observed streamflows can be lower than the 7010 discharge in consecutive years. During the 1998-2002 drought across North Carolina, 7-day average discharges were repeatedly lower than the 7010 discharge, particularly at gaging stations in the Piedmont Province.

During the 1998-2002 drought, streamflow conditions reached record-low levels, particularly during the 2002 water year. Record minimum values for 7-day average discharges were set at 74 of 150 continuousrecord streamflow-gaging stations having greater than 10 years of record through

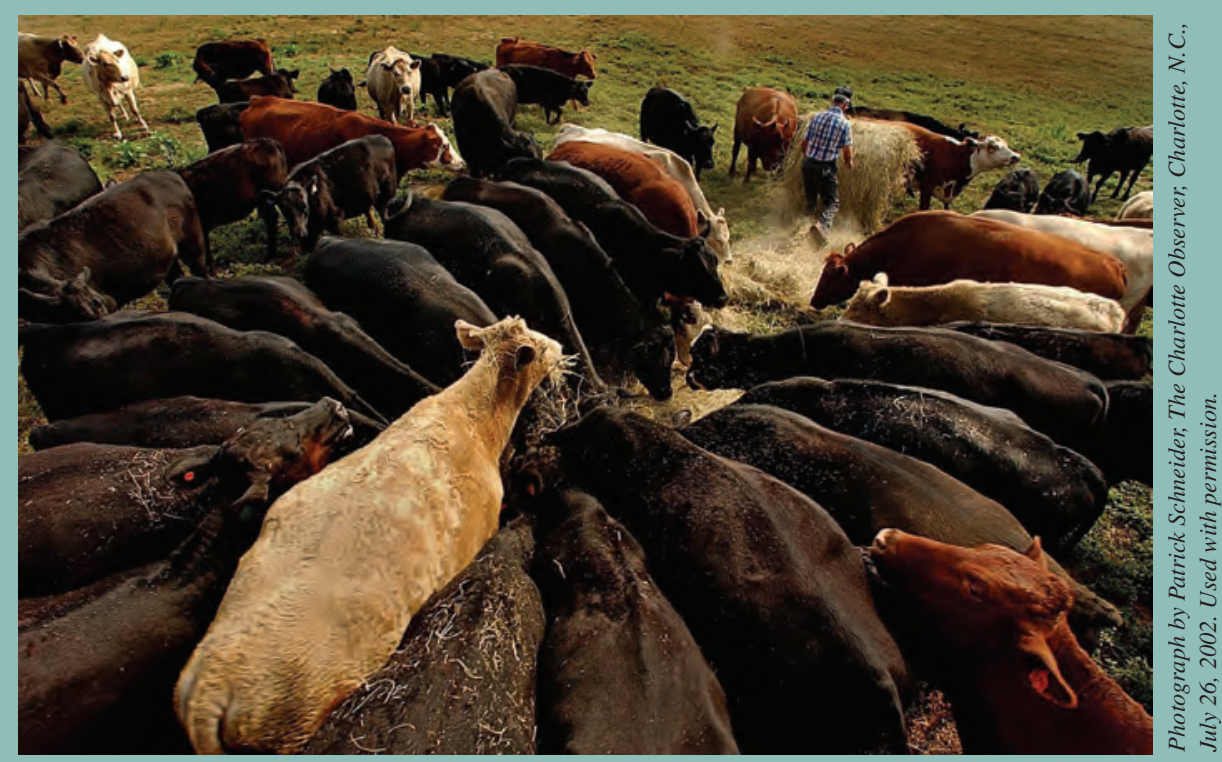

The drought forced a farmer in Statesville, N.C., to use almost half of his supply of winter feed for his cattle in July 2002. 
Table D-1. Summary of 7-day, 10-year low-flow discharges at selected streamflow-gaging stations prior to and following the 1998-2002 drought in North Carolina.

[USGS, U.S. Geological Survey; $\mathrm{mi}^{2}$, square mile; $\mathrm{ft}^{3} / \mathrm{s}$, cubic feet per second; 7Q10, 7-day, 10-year low-flow discharge. Available full period of record is listed for each station; the number of years of systematic record are based on the full period of record through the 2002 water year. Climatic year is the 12-month period beginning in April and ending in March, designated by the year in which the period begins. It is the standard period used in low-flow frequency analyses for continuous-record gaging stations]

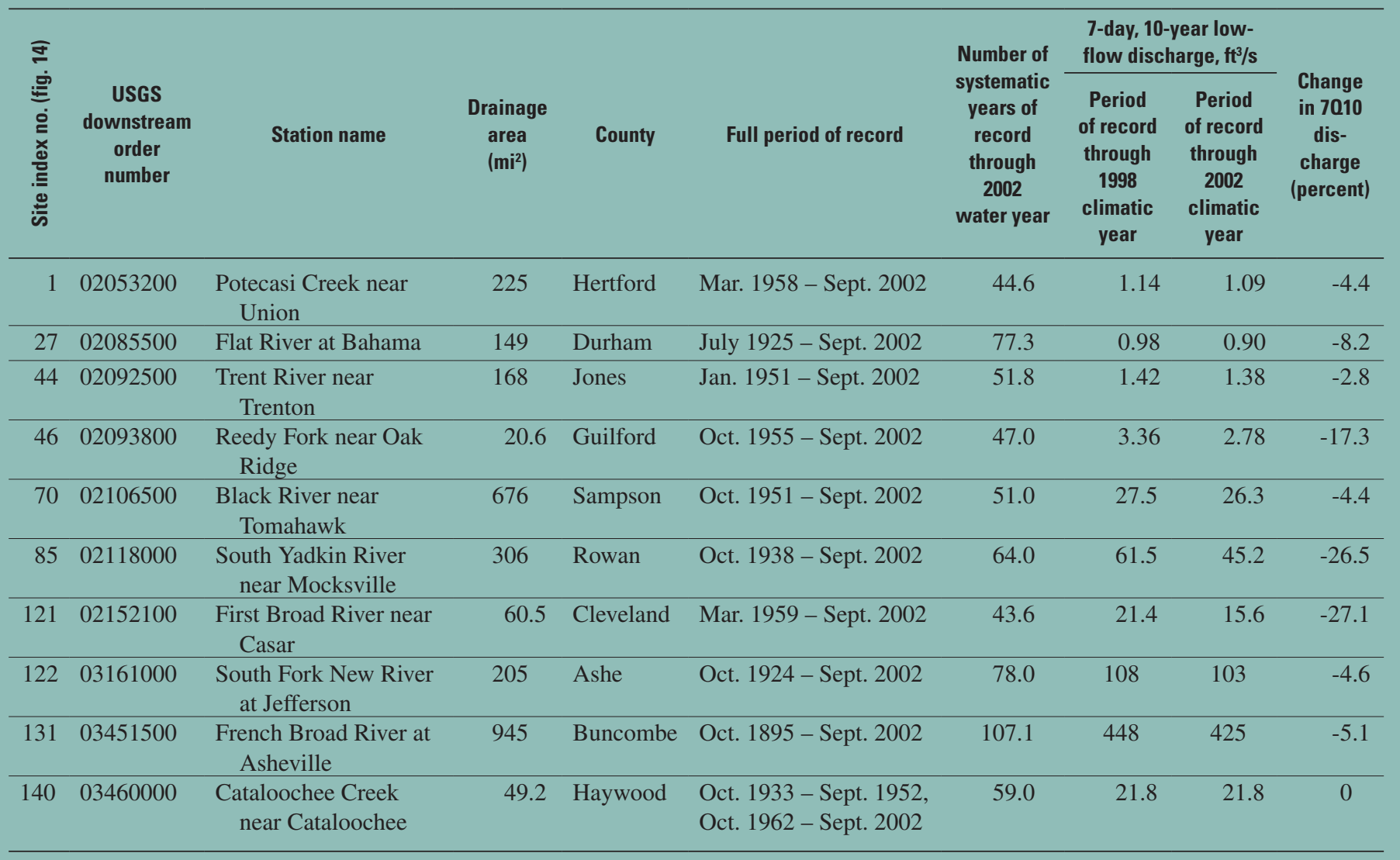

the 2002 water year (see table 3). Of these 74 sites, record minimum values for 7-day average discharges were set at 61 sites during the 2002 water year alone. However, aside from setting new record-low minimum streamflows, comparisons of the 7010 discharges provide some insight into the changes in low-flow frequency statistics at 10 selected gaging stations across North Carolina.

Changes in the 7010 discharge prior to and following the 1998-2002 drought varied among the 10 selected gaging stations, ranging from 0 to -27.1 percent (sites 140 and 121 , respectively). Percentage changes in the 7010 discharges were less than 10 percent for 7 of the 10 sites. The three sites having the largest differences in preand post-drought 7010 discharges (greater than 15 percent) are located in the western Piedmont, consistent with observations that drought conditions were more severe in this area of the State.

Methods used by the USGS to complete low-flow frequency analyses at continuous- record gaging stations require a minimum of 10 years of record (Riggs, 1972). As the period of record increases, values of 7010 discharge tend to become "locked" into a narrow range. In other words, the addition of several years of record does not result in a significantly revised value unless the annual minimum 7-day average streamflows reach very low levels (fig. D-1). At two gaging stations in the Piedmont Province (sites 85, $121)$, relatively significant decreases in the 7010 discharges occurred after several consecutive years of low 7-day average discharges. At site 85, several consecutive years of low 7-day average discharge occurred during the mid-1950s and 1998-2002 droughts (fig. D-1). Correspondingly, the 7010 discharge declined significantly following these droughts. Between the 1952 and 1956 climatic years ${ }^{2}$, the 7010 discharge

${ }^{2}$ The climatic year is the 12-month period beginning in April and ending in March, designated by the year in which the period begins. It is the standard period used in low-flow frequency analyses for continuous-record gaging stations. decreased from $82 \mathrm{ft}^{3} / \mathrm{s}$ to $50.3 \mathrm{ft}^{3} / \mathrm{s}$. From the 1998 to 2002 climatic years, the 7010 discharge at site 85 decreased from $61.5 \mathrm{ft}^{3} / \mathrm{s}$ to $45.2 \mathrm{ft}^{3} / \mathrm{s}$ (fig. D-1; table D-1). By contrast, the occurrence of a low 7-day average discharge in the 1986 climatic year alone did not result in the significant reduction in the 7010 discharge (fig. D-1). The 7010 discharge decreased from $63.7 \mathrm{ft}^{3} / \mathrm{s}$ to $58.3 \mathrm{ft}^{3} / \mathrm{s}$ during the 1985-86 climatic years. At the gaging station on the First Broad River (site 121), significant decreases in the 7010 discharge occurred following droughts in the mid-1980s and 1998-2002 (fig. D-1).

A statewide or other comprehensive assessment of changes in the 7010 discharge and other low-flow characteristics is beyond the scope of this report. Nevertheless, information obtained from the assessment of the 10 selected gaging stations (table D-1) reaffirms the recognition that significant changes in the 7010 discharges do occur following several consecutive years of very low streamflows. 

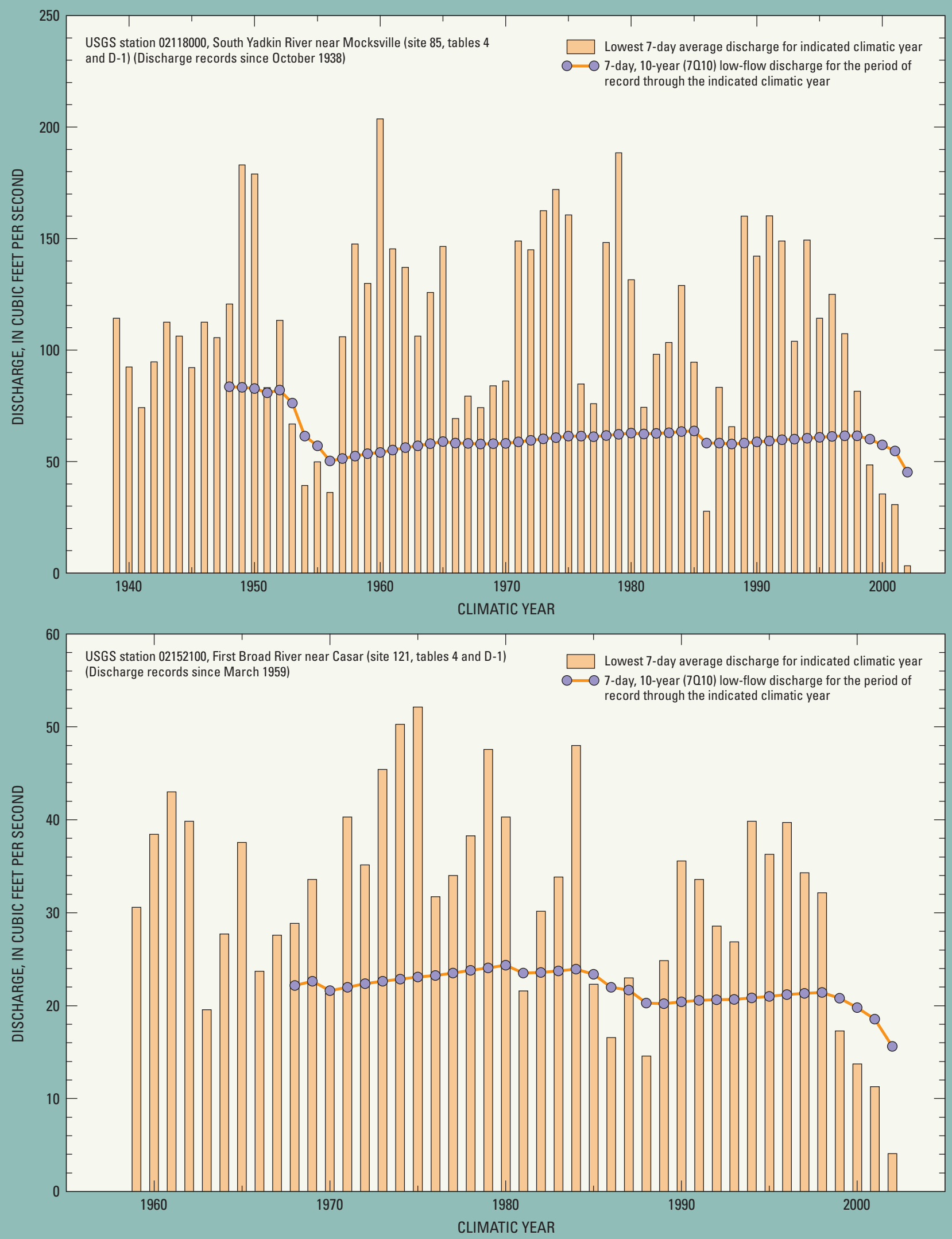

Figure D-1. Observed annual minimum 7-day average streamflows and estimated 7-day, 10-year low-flow discharge at two selected Piedmont streamgaging stations. Note: The climatic year is the 12-month period from April 1 through March 31 and is designated by the year in which the period begins. The climatic year is the standard period used in low-flow analyses for gaging stations. 


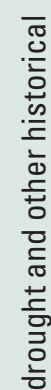

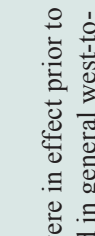

焉

赤 苛

ชั่

吕

:

离, 苋

돔

을

官

등

要

으

当

घ

氖

吾

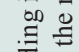

究

芩

这

ऐे

क्ञ

ํㅡㅇ

점

壱

ํํำ

递

ज

?

政

뜰

히휴

กึ:

क)

它

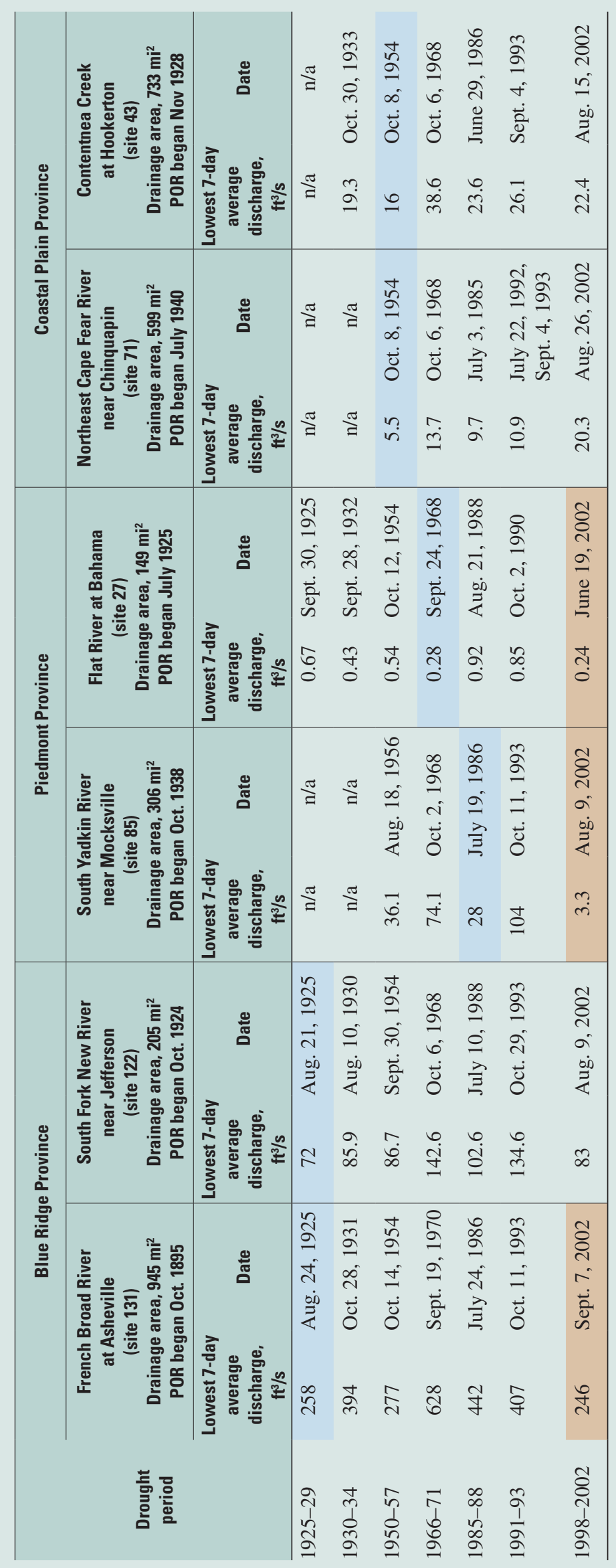




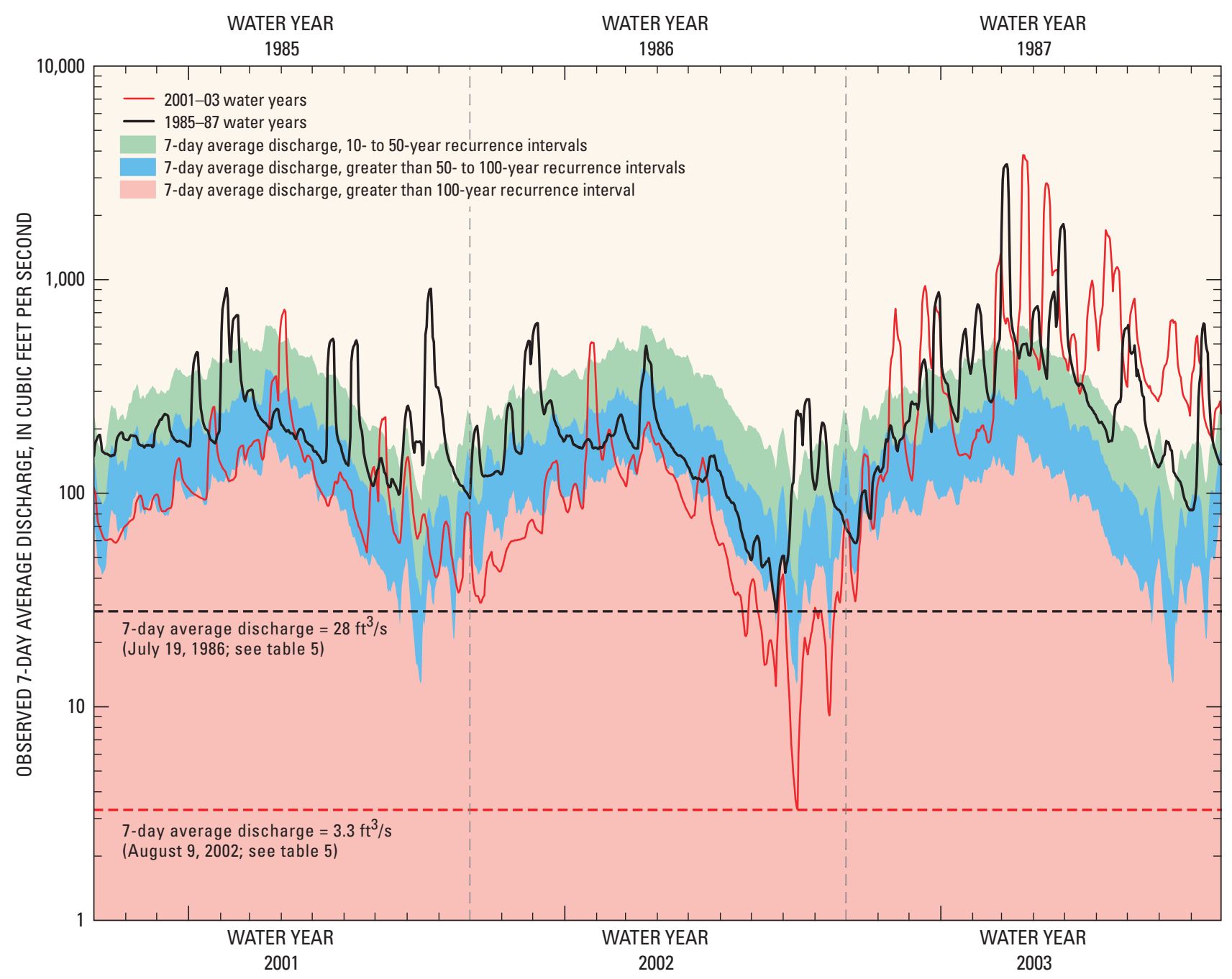

Figure 18. Observed 7-day average discharge at South Yadkin River near Mocksville (site 85, fig. 15) during the $1985-87$ and 2001-03 water years.

sites $(71,43)$, minimum 7-day average discharges set during the 1998-2002 drought did not surpass the period of record minimum 7-day discharges set at each site during the 1950-57 drought (table 5). These observations further confirm that the greatest effects of the 1998-2002 drought occurred at streams in the Piedmont and Blue Ridge Provinces. In terms of streamflow, the 1998-2002 drought generally was more severe than previous droughts for streams in these two provinces.

Concerns have been raised about the degree of meaningful comparisons that can be made in view of the increased demands being placed on surface-water bodies. With the increased population in North Carolina during the last 50 years, one could argue that the higher demands on streams were as much a factor in the low streamflows during the drought as the climate patterns. As previously discussed, no in-depth analyses were completed to distinguish the declining flows directly attributed to increased water use.

Such an assessment, even for selected streams, requires additional investigation and is beyond the scope of this report. Nevertheless, the occurrence of record-high precipitation deficits in the Piedmont and Blue Ridge Provinces supports the conclusion that drought conditions during 1998-2002 were more severe than those during many historical droughts in North Carolina, particularly those documented since the systematic collection of weather records began in the late 1800 s.

\section{Ground Water}

Ground-water-level data were collected from 137 observation wells across North Carolina in the 2002 water year and published in the USGS annual data report for North Carolina (Howe and others, 2003; table 6). Of the 137 wells, 96 wells were operated to monitor the effects of human-induced stresses (namely, ground-water withdrawals) on the ground-water system, and 41 
Table 6. Summary of U.S. Geological Survey observation wells operated during the 2002 water year in North Carolina.

[Numbers of wells were obtained from the U.S. Geological Survey 2002 annual data report for North Carolina (Howe and others, 2003)]

\begin{tabular}{lccc}
\hline & $\begin{array}{c}\text { Wells affected by } \\
\text { withdrawals }\end{array}$ & $\begin{array}{c}\text { Climate-response } \\
\text { wells }\end{array}$ & Total \\
\hline Wells operated during the 2002 water year & 96 & 41 & $137^{\mathrm{a}}$ \\
Wells at which new record-low water levels for the periods & 73 & 27 & 100 \\
$\quad$ of record were set during the 2002 water year & 61 & 10 & 42 \\
Wells with greater than 5 years of record & 35 & & 45 \\
$\begin{array}{l}\text { Wells with greater than 5 years of record at which new } \\
\text { record-low water levels were set during the 2002 water }\end{array}$ & & \\
$\quad$ year & & & \\
\hline
\end{tabular}

${ }^{a}$ Ground-water-level data were actually collected from a total of 143 observation wells in the 2002 water year (Howe and others, 2003). However, the total number includes 7 observation wells in Craven County where a small number of miscellaneous measurements were made during the period from March through August 2002.

wells were operated to monitor changes in ground-water storage in response to climate changes. New record-low ground-water levels for the periods of record were observed at 100 of the 137 wells during the 2002 water year. Further examination of the ground-water data at sites having at least 5 years of record through the 2002 water year indicates that new record-low water levels for the periods of record were set at 45 of these wells (Howe and others, 2003; table 6).

The spatial distribution and periods of record for USGS observation wells having long-term continuous records in North Carolina are smaller relative to those in the network of surface-water sites. Much of the historical groundwater data collection has been in the Coastal Plain; a relatively smaller amount of ground-water data has been collected in the Piedmont and Blue Ridge Provinces. Several wells in North Carolina have long-term systematic (total) records consisting of periodic measurements and continuous records, but 5 of the 41 climate-response wells had greater than 20 years of continuous record in the 2002 water year.

The NCDWR monitors water levels at 42 wells designated as droughtindicator wells across the State (North Carolina Division of Water Resources, 2004), 26 of which currently (2004) are operated by the USGS in cooperation with NCDWR. Record-low water levels were set at about half of the 42 wells during the 1998-2002 drought, and most of the records were set during the 2002 water year when hydrologic conditions were at the lowest levels. This is consistent with the temporal distribution of record-low streamflows that were set at gaging stations during the drought in that the vast majority of records were set during the 2002 water year.

Examination of ground-water records collected by the USGS and NCDWR resulted in the selection of 21 climate-response wells that were spatially distributed across the State and would provide some indication of the lowest water levels that existed prior to the 1998 water year and during the 1998-2002 water years (fig. 19; table 7). Most of the 21 selected wells are part of the Ground Water Climate Response Network of wells identified by the USGS during the 1998-2002 drought to provide a 100 years. quick means of assessing ground-waterlevel conditions across the United States (U.S. Geological Survey, 2004).

Included in the 21 selected wells are 5 wells (sites 153, 155, 159, 163, and 168; table 7) that have periods of continuous record greater than 20 years. Of the remaining 16 wells, 9 wells had

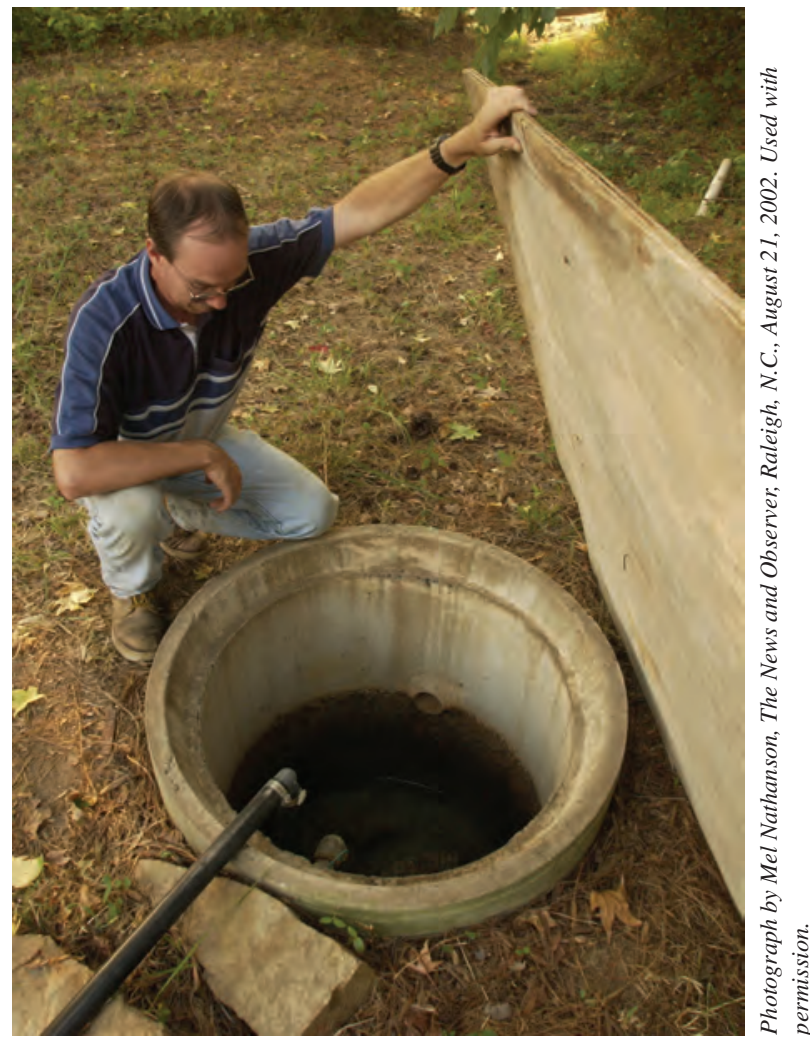

Extreme drought conditions in the summer of 2002 caused a spring on a farm south of Monroe, N.C., to dry up for the first time in nearly 


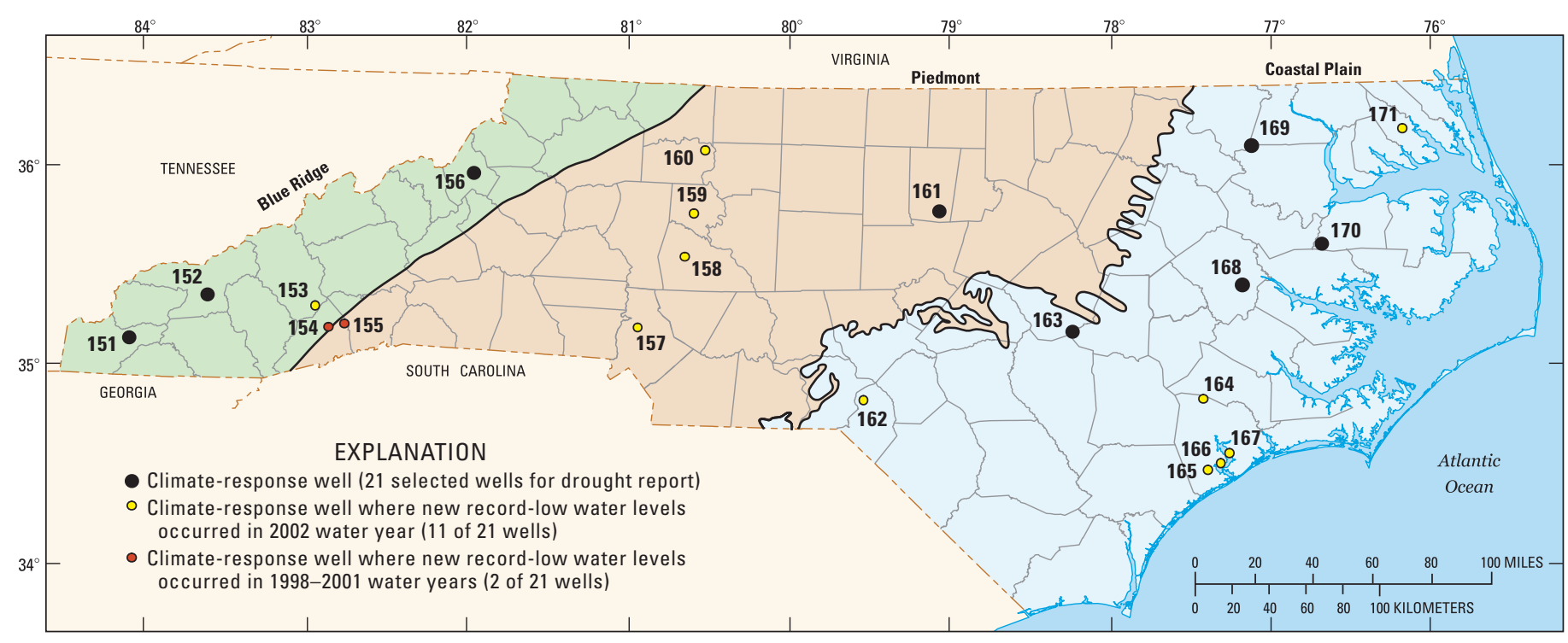

Figure 19. Selected U.S. Geological Survey climate-response observation wells in North Carolina.

10-20 years of continuous record, 4 wells had 5-10 years of continuous record, and 3 wells had less than 5 years of continuous record as of the 2002 water year (table 7). At the three wells with less than 5 years of continuous records (sites 152, 156, and 160) and one well (site 161) with 5-10 years record, periodic measurements made during earlier periods ranging from 28 to 42 years provided long-term data.

\section{Ground-Water-Level Conditions During the 1998-2003 Water Years}

Record-low water levels were set at 13 of the 21 selected wells during the 1998-2002 water years (table 7; fig. 19). Records were set at 11 of the 13 sites during the 2002 water year alone (fig. 19). The well having the longest period of continuous record (site 153, table 7; fig. 19), dating from December 1955 , is among these 11 wells. The records at the other two wells were set during the 1999 and 2001 water years (sites 154 and 155, respectively). Where new record-low water levels were set during the 1998-2002 drought, the difference between the pre-drought and new records ranged from 0.05 to
2.85 feet (ft; sites 164 and 158, respectively; table 7) among the 13 wells.

With the exception of three wells in the Blue Ridge and western Piedmont, the water-level data from the selected wells indicate fluctuations in the surficial aquifer (water table). The three deep wells (sites 152, 156, and 160; table 7) range from 300 to $500 \mathrm{ft}$ deep and are used to measure water levels in the underlying bedrock. These wells were included in this assessment to demonstrate that deeper wells can be affected by drought conditions. While water levels in deep wells respond to climate changes, the fluctuations (when expressed as percentage of the well depth) are typically smaller than those observed in shallow surficial aquifers. The pre-drought record-low water level at one of the deep wells (site 160) was exceeded by about $1 \mathrm{ft}$ (table 7). At the other two deep wells, water levels during the drought were higher than pre-drought records by about 1.2 and $0.6 \mathrm{ft}$ (sites 152 and 156, respectively). No deep wells in the Coastal Plain were included in this assessment because many of these wells are affected by pumping in addition to climate changes.

For this report, water-level records for 5 of the 21 selected wells were chosen to illustrate the effects of the 1998-2002 drought. These wells were selected because each has at least 15 years of continuous record and is in close proximity to a nearby long-term streamflow-gaging station. Data from the resulting five pairs of surface-water and ground-water sites were examined to assess the decline and recovery that occurred during the drought. The five selected wells are NC-144 at Blantyre in Transylvania County (site 155), NC-146 at Hornets Nest Park in Mecklenburg County (site 157), NC-142 at Mocksville in Davie County (site 159), NC-194 at Marston in Scotland County (site 162), and NC-173 at Comfort in Jones County (site 164, table 7; fig. 19).

Effects of the 1998-2002 drought on ground water in North Carolina varied during the course of the event. Overall water-level declines throughout the drought were continuous for the wells at Blantyre (NC-144) and Mocksville (NC-142, fig. 20), although declines at Hornets Nest (NC-146), Marston (NC-194), and Comfort (NC-173) were more pronounced during the 2000-2002 water years. Excluding the Hornets Nest well, the patterns indicate that drought effects were more pronounced in the western half of the State. In the Coastal Plain, water-level declines did not begin to occur until early to mid-2001 when water levels declined to below-normal ranges (25th 


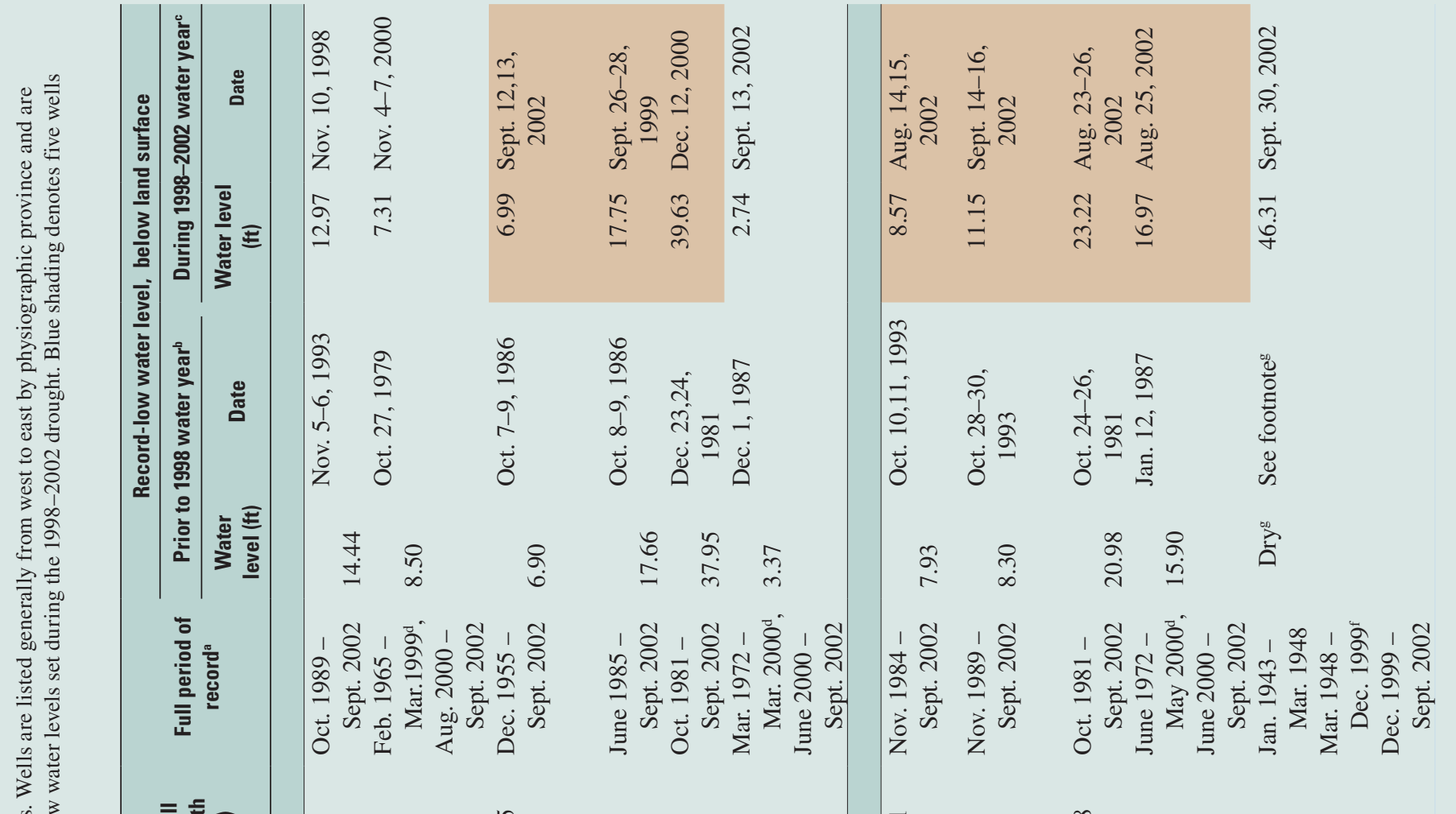

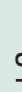

.

응

我

言褰

2)

$\stackrel{\infty}{\stackrel{5}{2}}$

总

Ф)

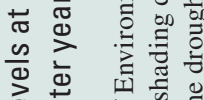

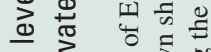

离

空

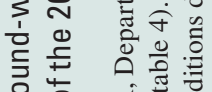

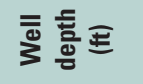

(2)

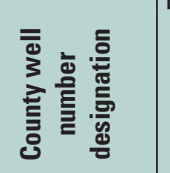

$\stackrel{\infty}{\infty}$

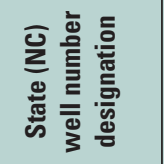

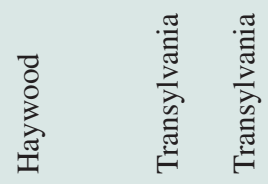

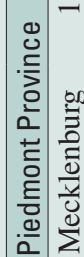

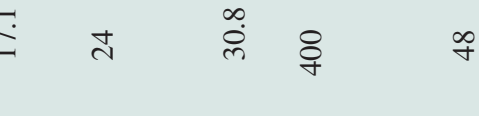

(a)

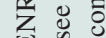

定 $\stackrel{0}{=}$

19

范

ญ

은 들

ஹ.

을 응

党

ब 능

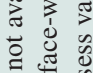

完言势

莽

$=$

to

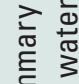

站咅

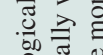

के 핟

ธे छ

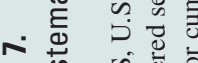

。

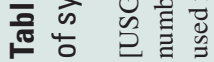

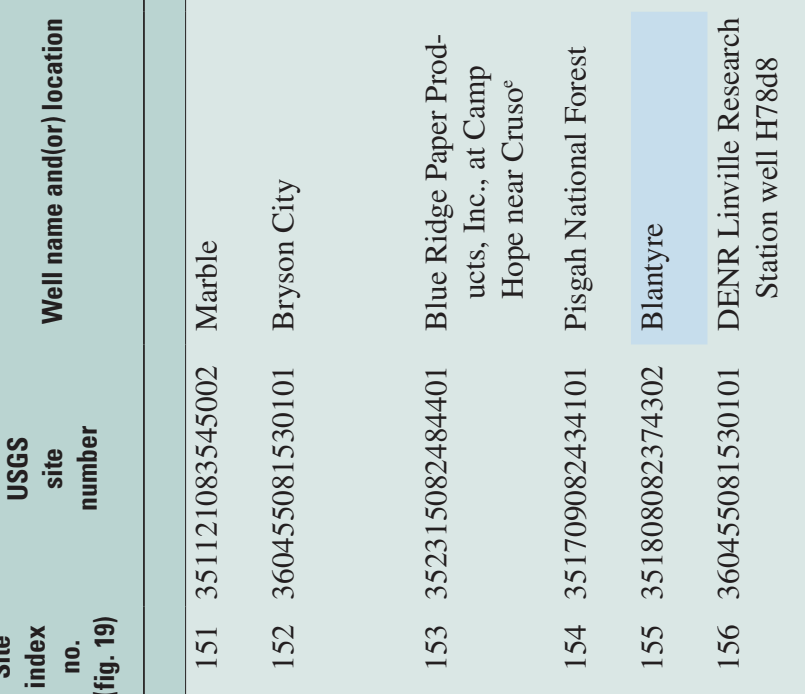

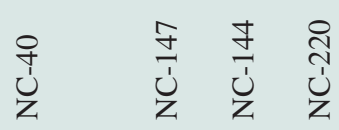

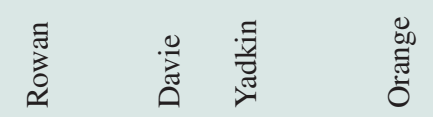

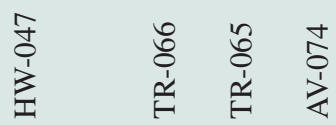

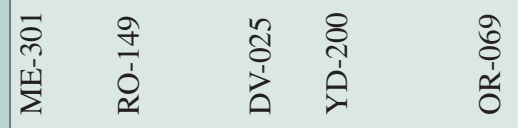

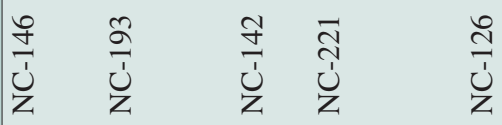

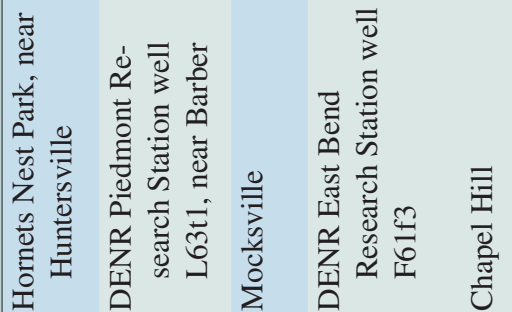

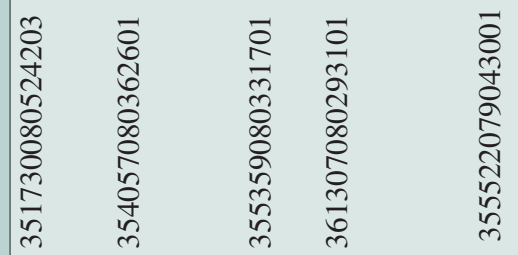

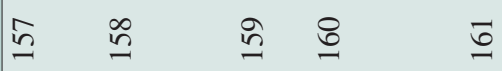



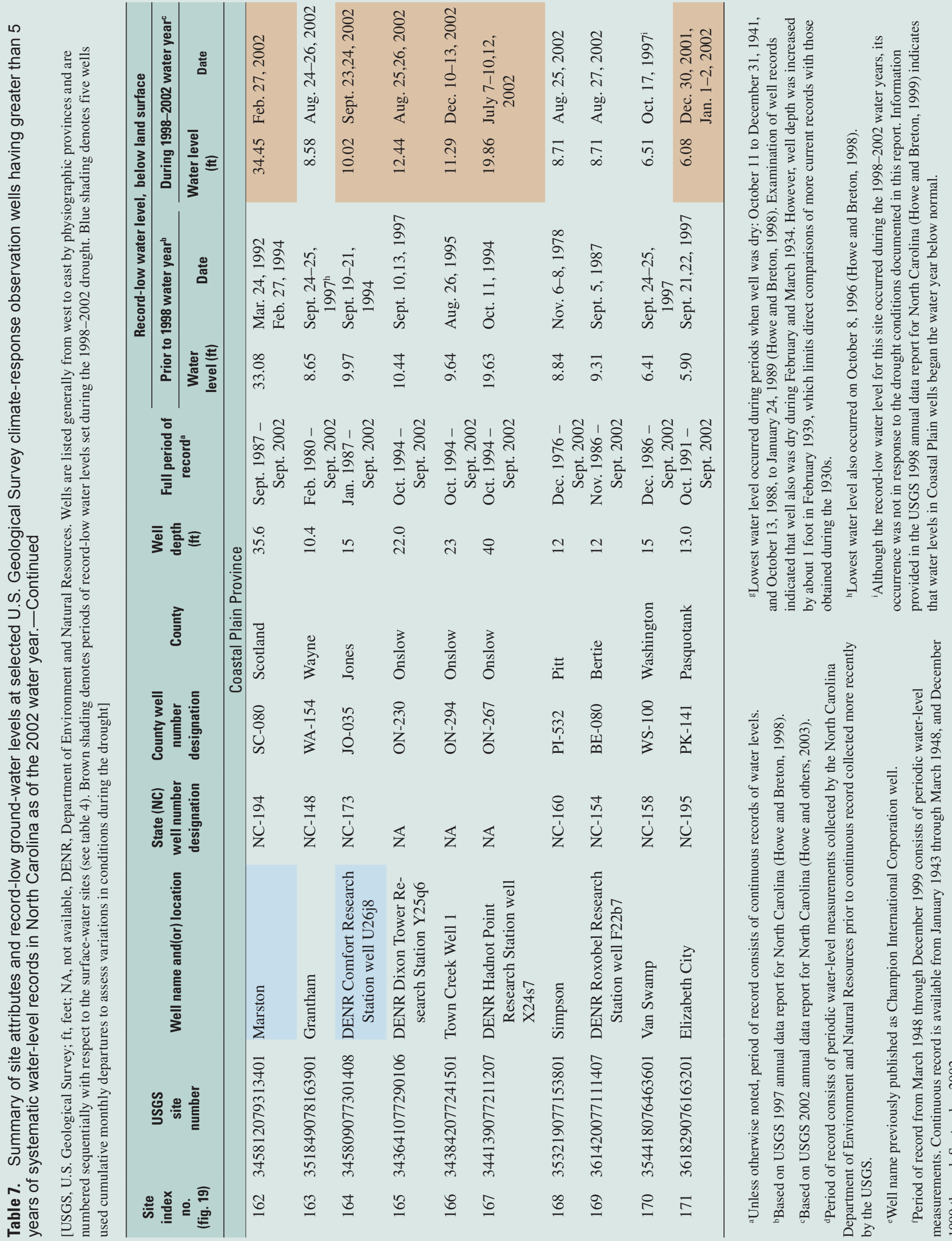
50 The Drought of 1998-2002 in North Carolina-Precipitation and Hydrologic Conditions

NC-144, Blantyre (site 155)

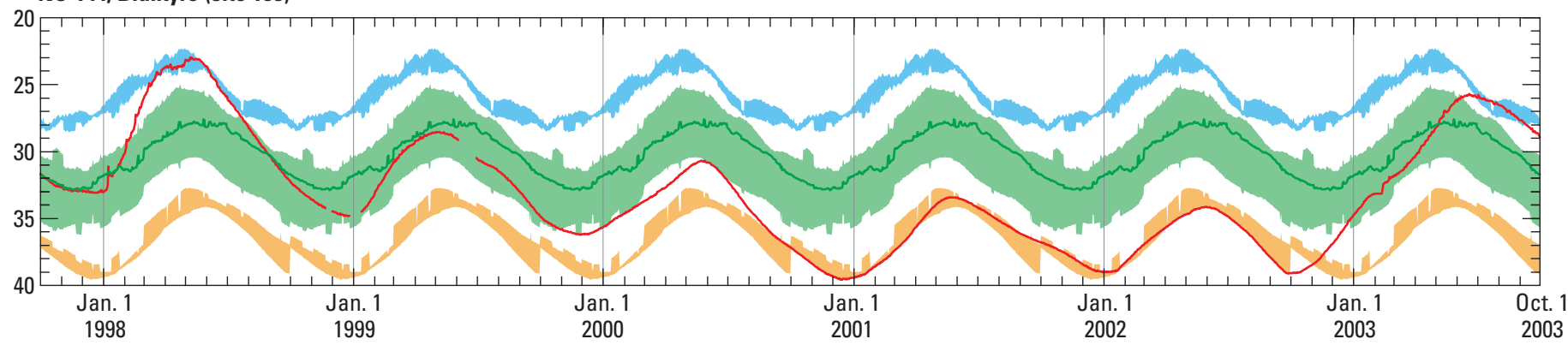

NC-146, Hornets Nest Park (site 157)

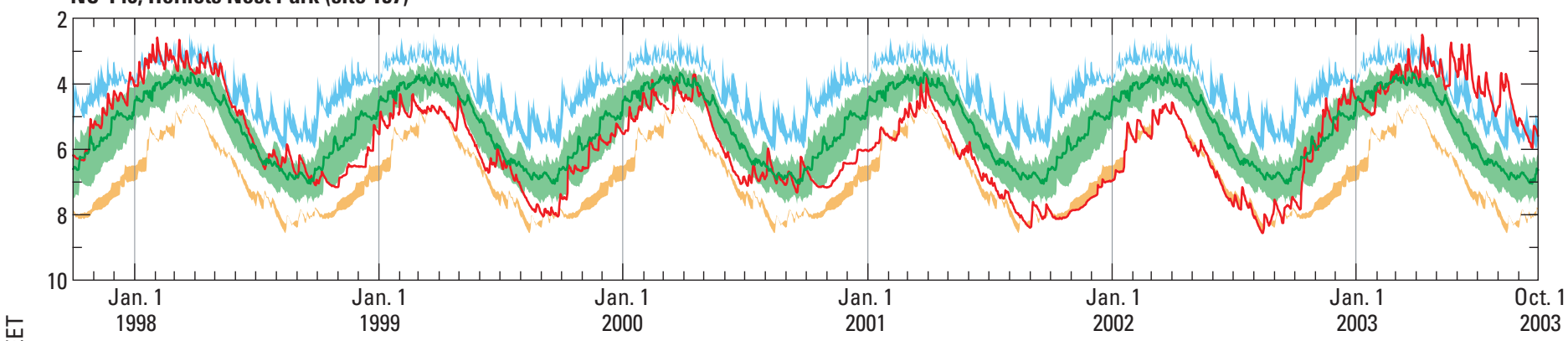

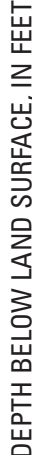

NC-142, Mocksville (site 159)

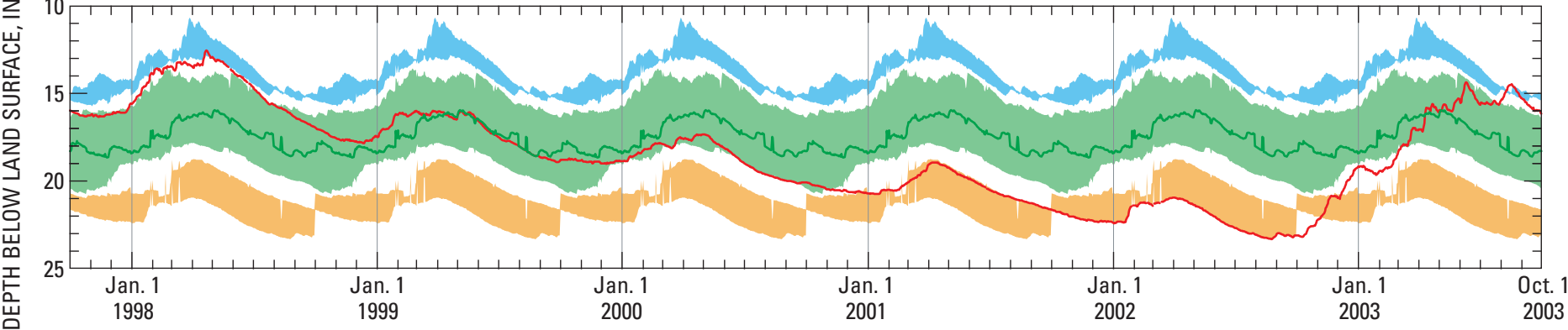

NC-194, Marston (site 162)

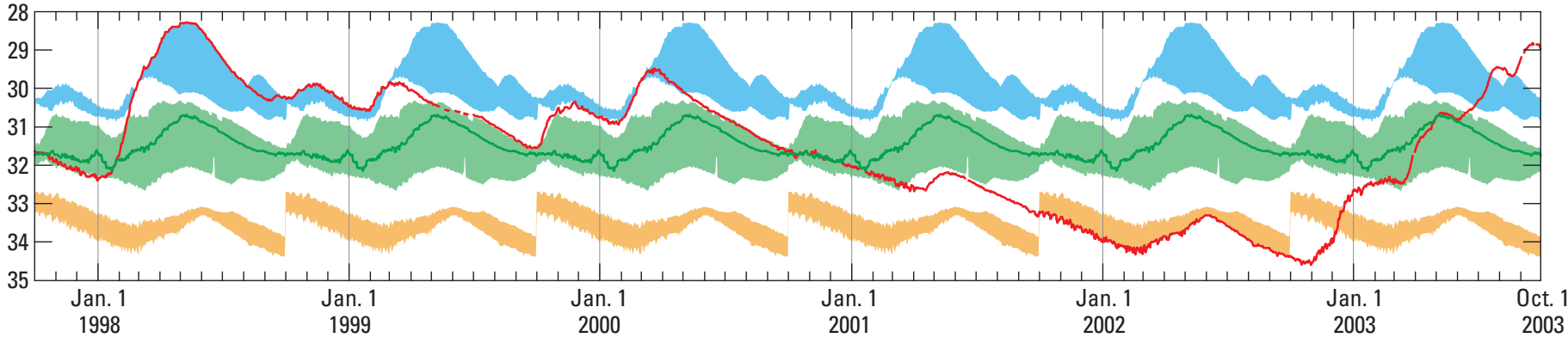

NC-173, Comfort (site 164)

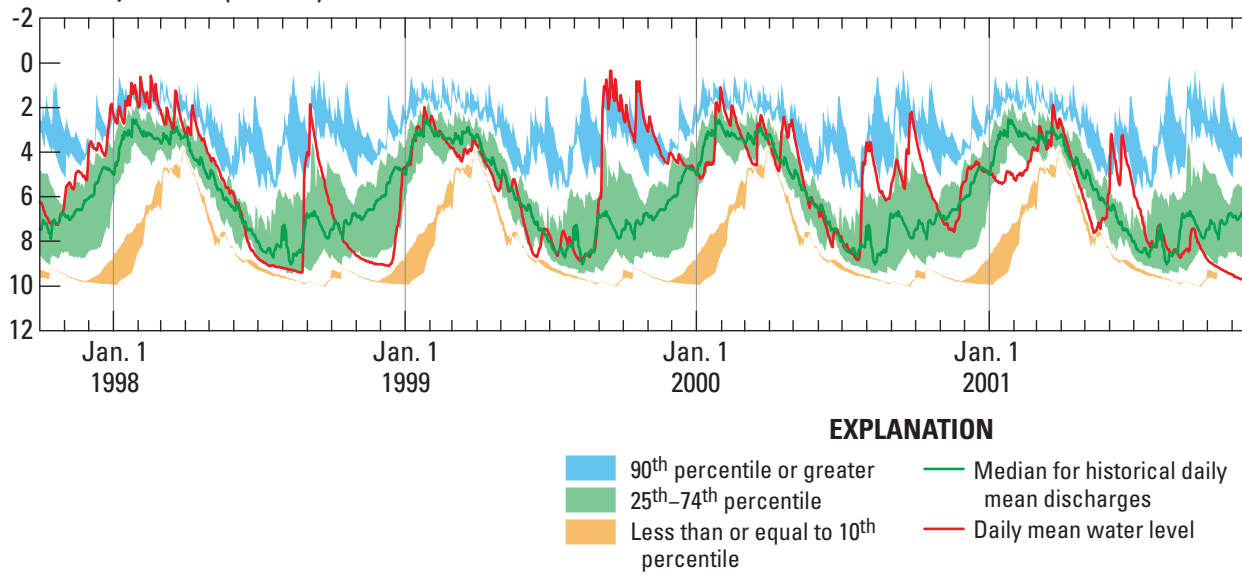

Figure 20. Ground-water hydrographs at five selected wells in North Carolina, 1998-2003 water years. 
to 75 th percentiles). By early and mid-2002, water levels were consistently below the 10th percentiles at all wells, and new record-low water levels (for the calendar day) were being set almost daily (fig. 20).

Recovery of daily water levels at most observation wells began in October 2002 following above-normal rainfalls during the previous 2 months. As abovenormal precipitation continued through the winter and spring, water levels at most wells returned to normal ranges by February and March 2003 and continued to be above normal for the remainder of the 2003 water year. The Hornets Nest well in Mecklenburg County (site 157, fig. 21) is a good example of the varying water-level changes in a shallow well. In mid-October 2002, water levels increased sharply by almost $2 \mathrm{ft}$ from the $<10$ percentile (October 10) to median levels (October 17) in response to nearly 2.25 inches of rainfall on October 11 (National Oceanic and Atmospheric Administration, 2003a). Given that the Hornets Nest well is $17 \mathrm{ft}$ deep (table 7), the water level was very responsive to precipitation, as indicated by the jagged appearance of the hydrograph at this site (fig. 21).

\section{Comparison of Ground-Water Levels During 1998-2002 with Historical Droughts}

The relatively short periods of record at observation wells across North Carolina precludes the comparison of water-level declines during 1998-2002 with those that occurred during many of the historical droughts documented in the State. For many of the 21 wells selected for the purpose of this study (table 7), water levels during the 1984-89 drought provide the only historical reference for comparing the most recent drought with earlier occurrences. Therefore, comparisons were made using the periods of pre-drought minimums of record for the wells as opposed to using periods associated with documented historical

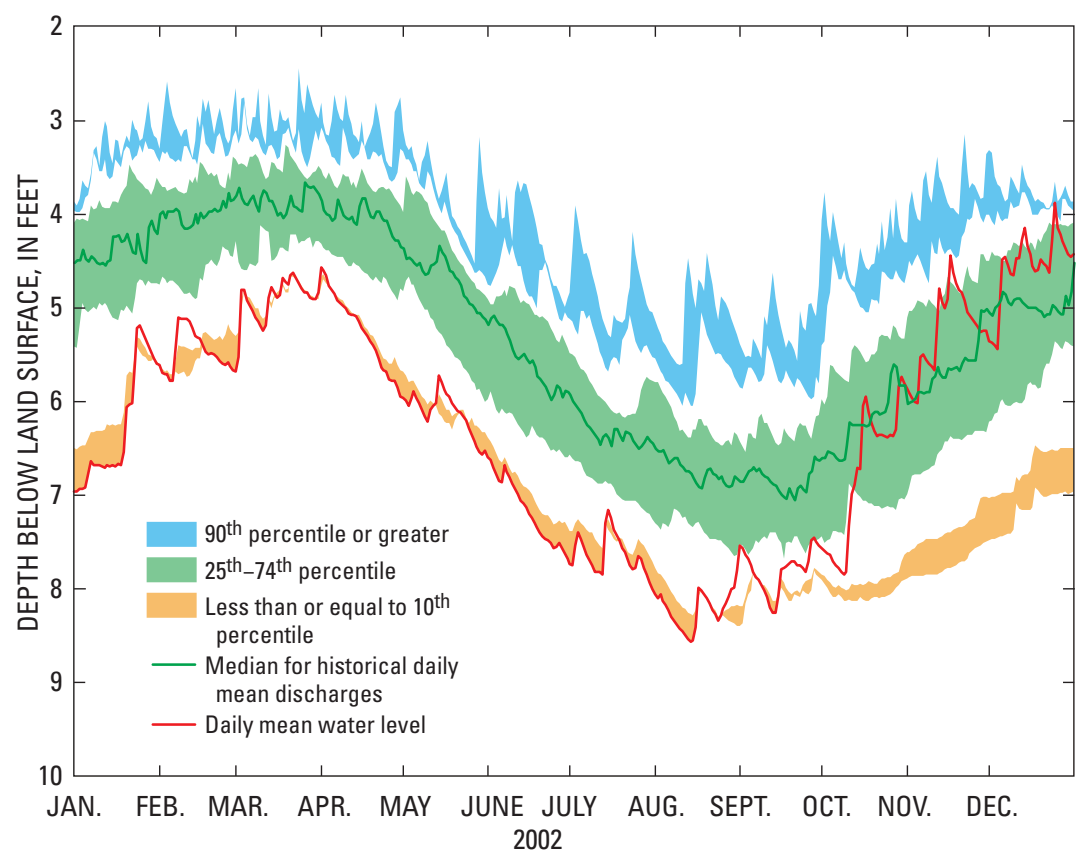

Figure 21. Ground-water hydrograph at NC-146 (site 157, Hornets Nest Park, Mecklenburg County) in North Carolina, 2002. droughts. Water levels at two wells having the longest periods of continuous record (sites 153, 168) and three of the five wells previously discussed (sites
155,159 , and 164 , table 7) were used in these comparisons (figs. 22-26).

At the Blue Ridge Paper Products well (site 153, fig. 22) and the Simpson

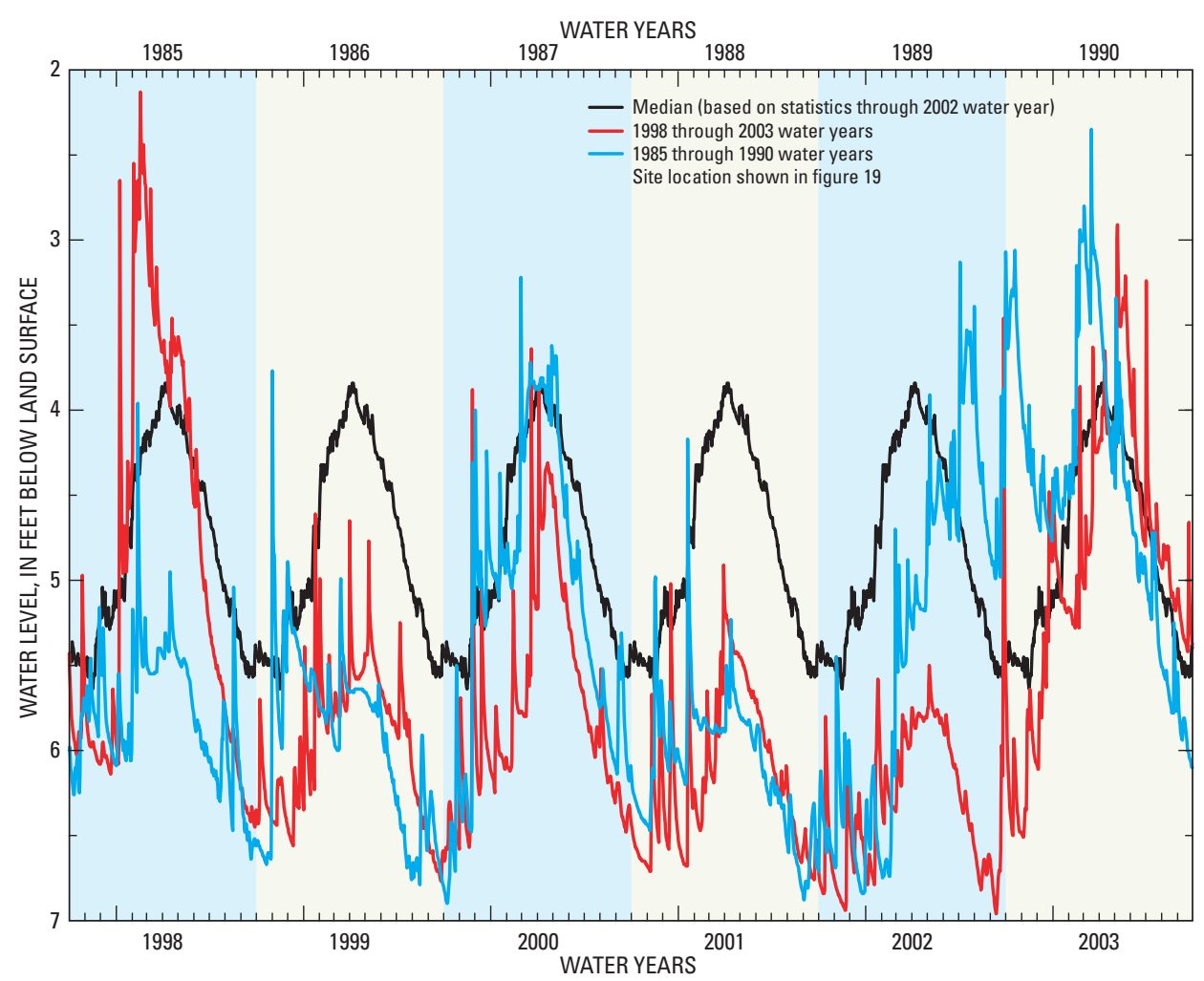

Figure 22. Water levels at NC-40 (site 153, Blue Ridge Paper Products well, Haywood County) during the 1985-90 and 1998-2003 water years. 


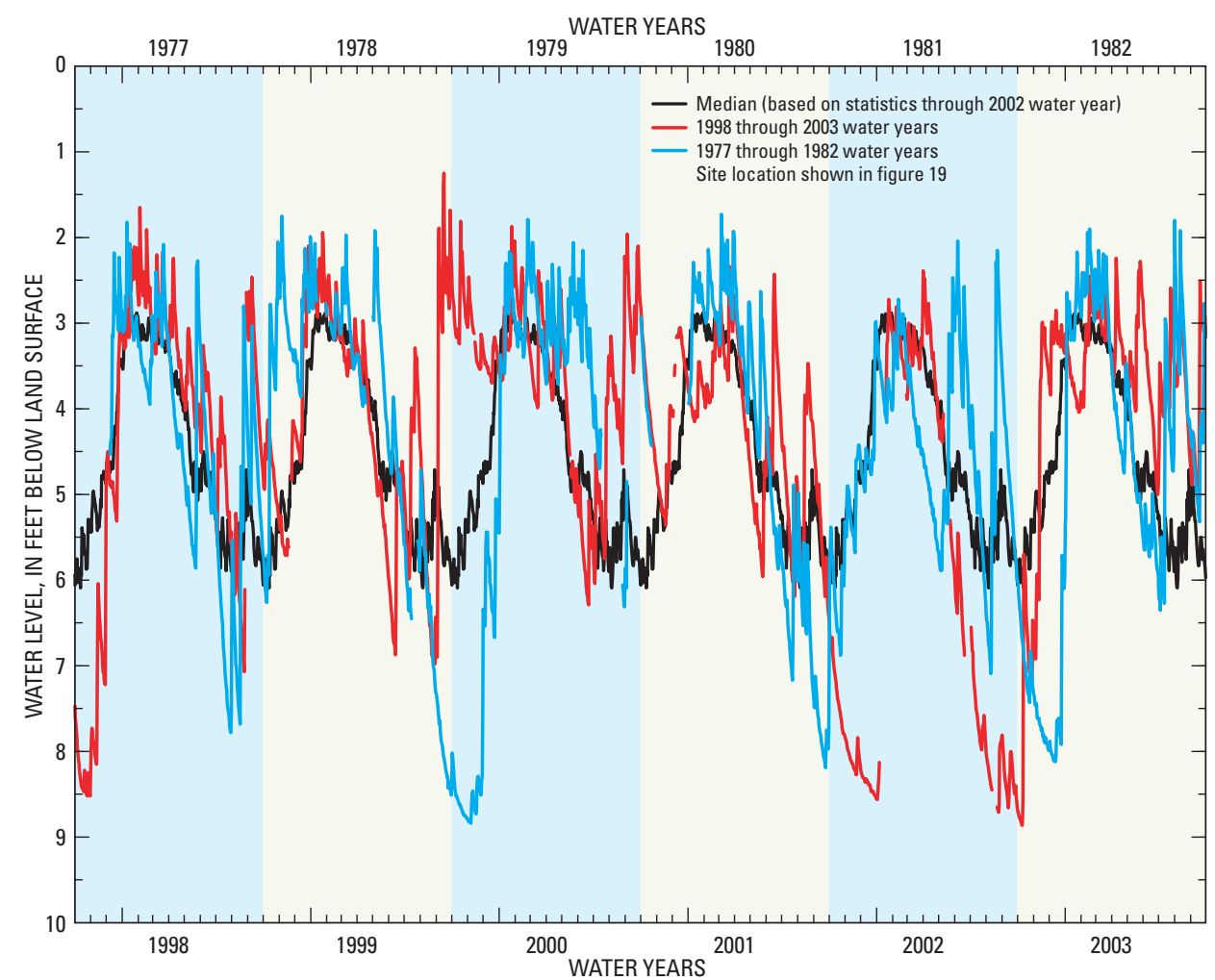

Figure 23. Water levels at NC-160 (site 168, Simpson well, Pitt County) during the 1977-82 and 1998-2003 water years.

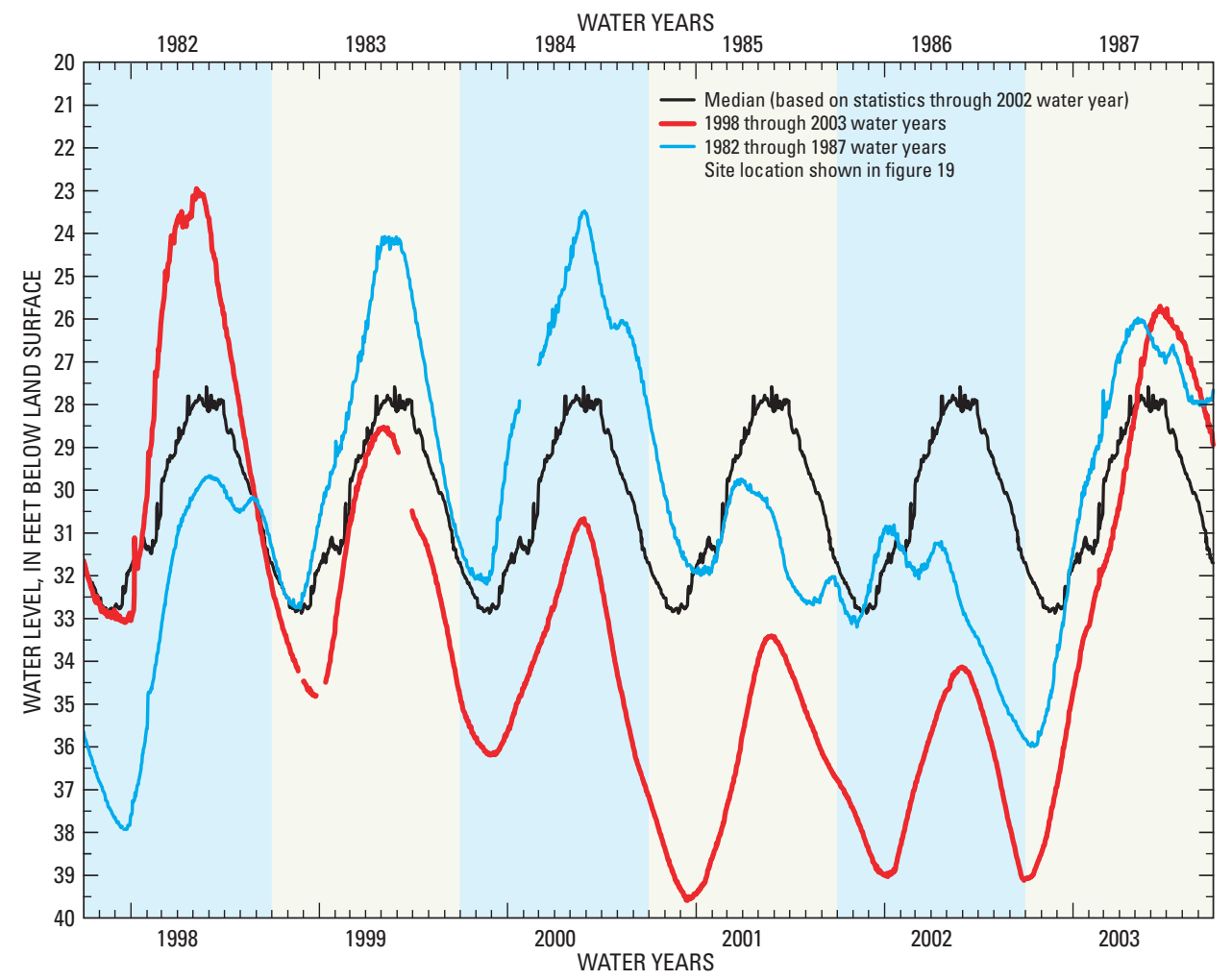

Figure 24. Water levels at NC-144 (site 155, Blantyre well, Transylvania County) during the 1982-87 and 1998-2003 water years. 


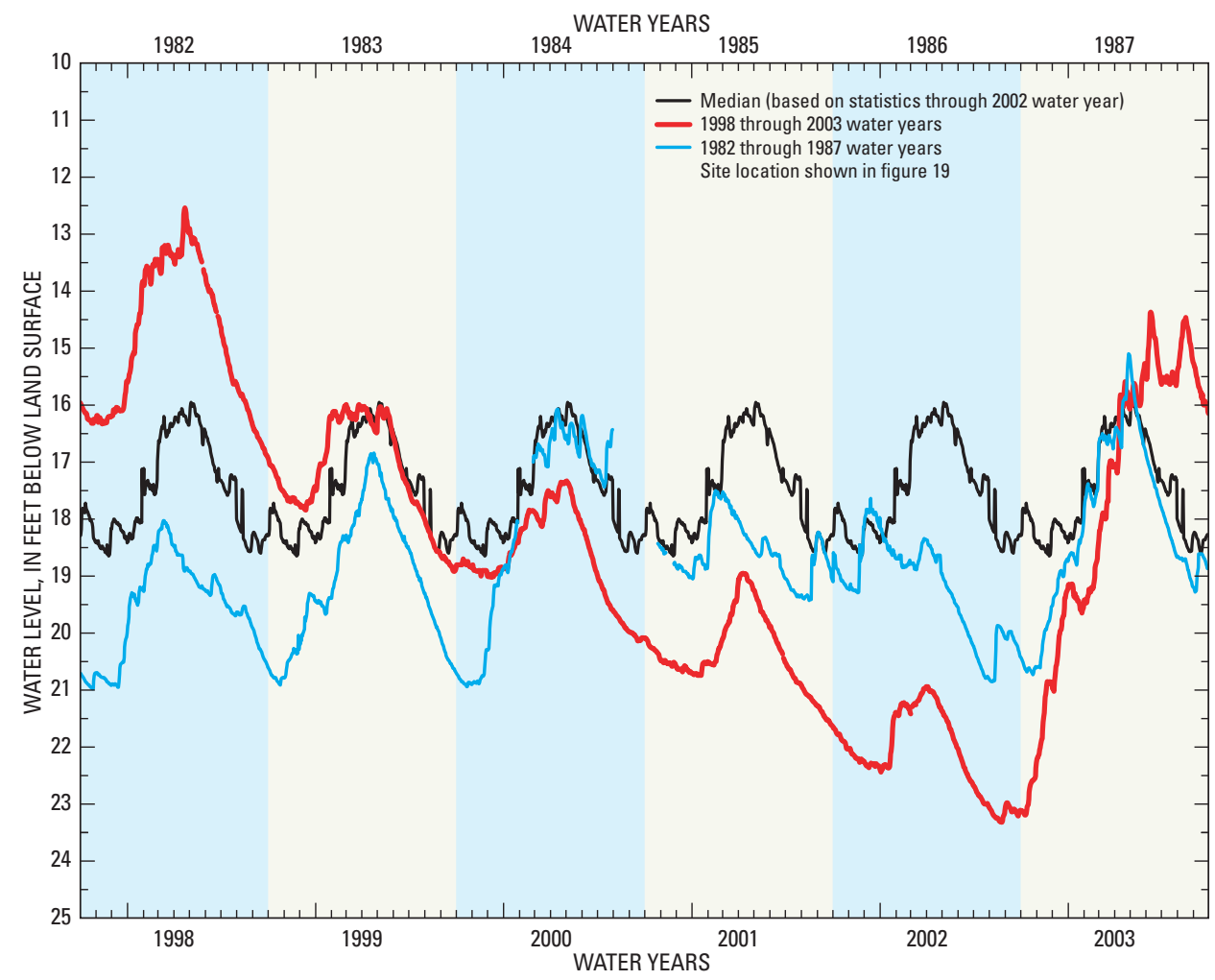

Figure 25. Water levels at NC-142 (site 159, Mocksville well, Davie County) during the 1982-87 and 1998-2003 water years.

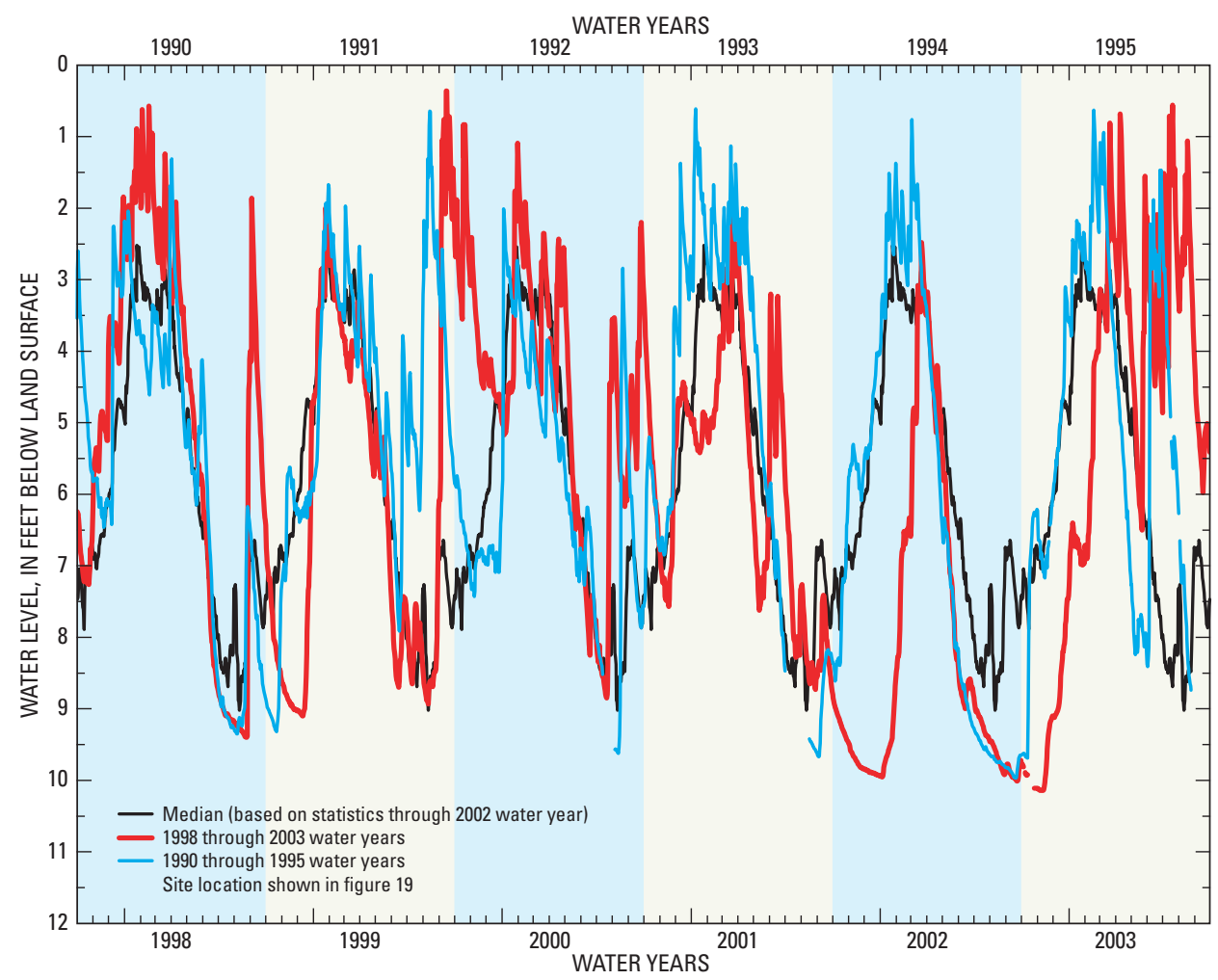

Figure 26. Water levels at NC-173 (site 164, Comfort well, Jones County) during the 1990-95 and 1998-2003 water years. 


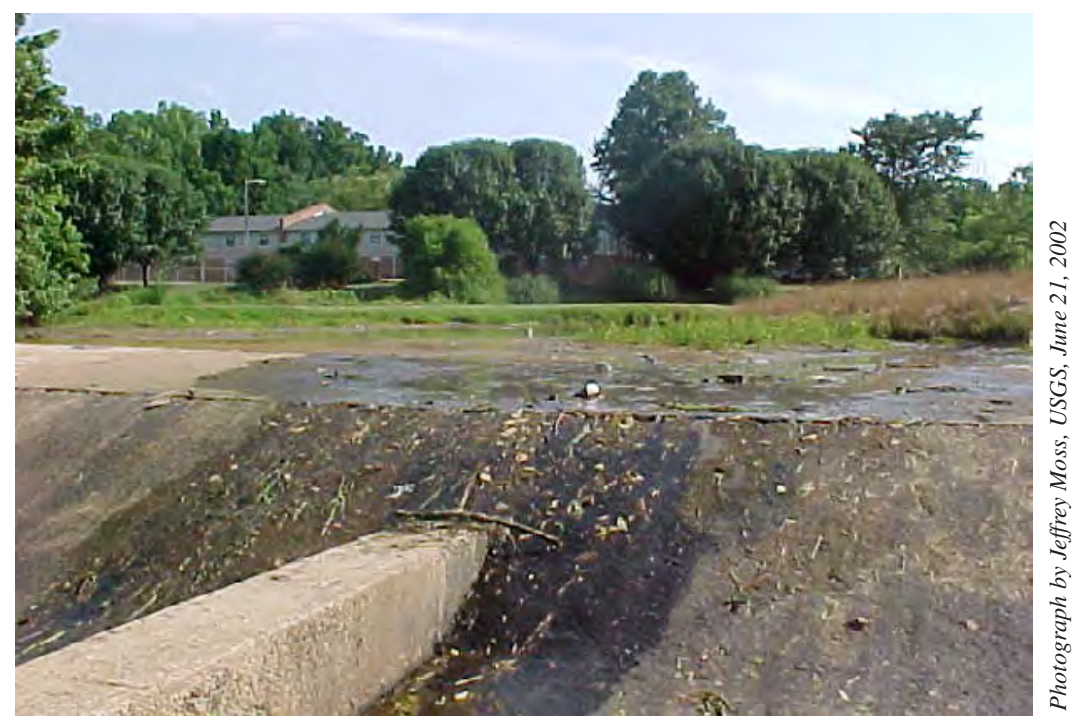

Extreme low-flow conditions at Briar Creek above Colony Road at Charlotte.

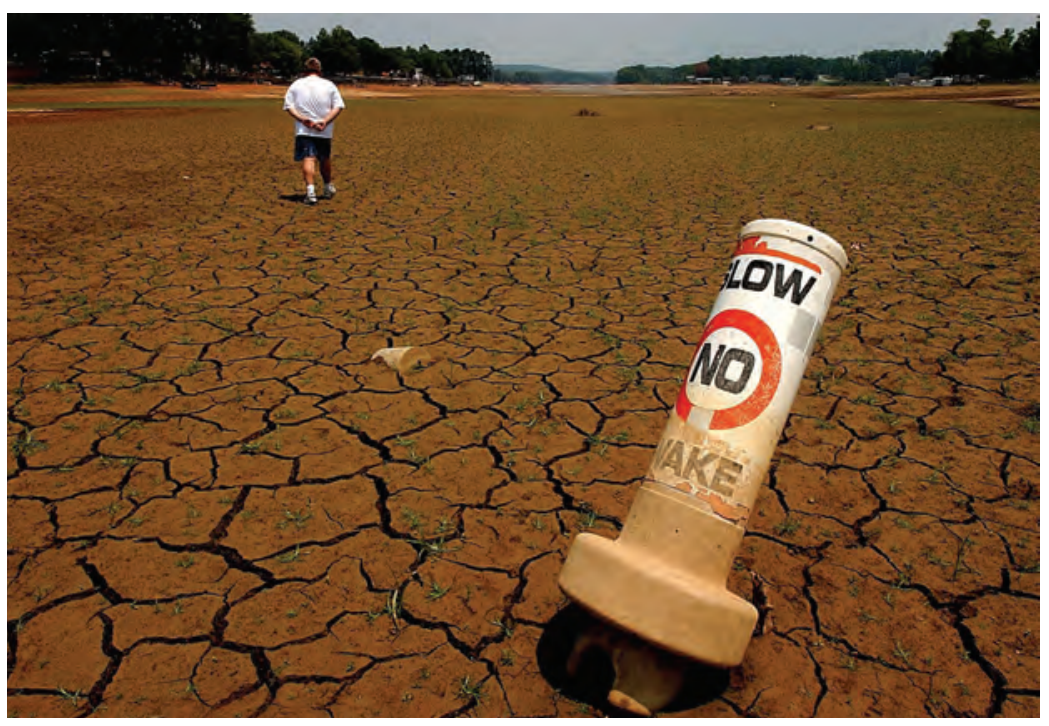

High Rock Lake in Davidson County was 15 feet below full pond on July 5, 2002.

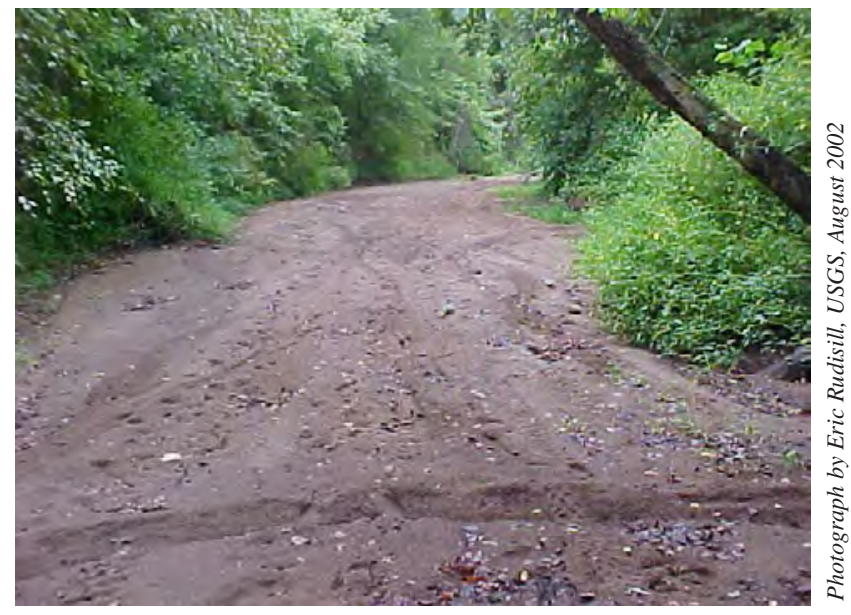

Dry streambed at Coddle Creek above Lake Don T. Howell in Cabarrus County. The lake, which is owned and operated by the Water and Sewer Authority of Cabarrus County, is the water supply for the county and nearby Concord, N.C. 
well (site 168, fig. 23), overall water levels during the 1998-2003 water years were comparable to those that occurred during previous periods (1985-90 and 1977-82 water years, respectively) in which pre-drought minimums were established. In fact, the differences in pre-drought and new record minimums at both these sites were less than $0.15 \mathrm{ft}$ (table 7). At the other three wells, water levels in the 1998-2003 water years were noticeably lower during the recent drought than levels that occurred during periods when pre-drought minimums were established. Particularly during the 2000-2002 water years, water levels at the Blantyre (site 155) and Mocksville (site 159) wells were at or below levels during the corresponding months in the 1984-86 water years (figs. 24, 25). At the Comfort well (site 164), overall water levels in 1998-2003 water years were very comparable to those in the 1990-95 water years, and the difference in minimum records was $0.05 \mathrm{ft}$, the smallest among the 21 wells (fig. 26; table 7).

\section{Surface-Water and Ground-Water Time Lags (Drought Recovery Rate)}

In considering the effects of drought on the hydrologic system, the distinctions between the surface water and ground water quickly become less discernible. Droughts serve as a reminder that the issue is not so much surface water or ground water but water itself. During droughts when streamflows are reduced to base flows, the base flows are sustained by ground water discharged from the aquifers to the streams. Streamflows respond more quickly to changing climate conditions than ground water, and the time lag between the beginning of a drought and the start of declining ground-water levels is longer than that for streamflows. This time-lag pattern continues following the end of a drought when streamflows are returning to normal and ground-water levels may still be declining. Perhaps an appreciation of the hydrologic responses to droughts can be obtained by comparing the time lags between monthly cumulative precipitation departures and monthly surface-water and ground-water departures during the 1998-2003 water years at sites located in close proximity to each other. Declining trends in the monthly departures represent periods in which a parameter (precipitation, streamflow, or ground water) is below normal while increasing trends represent periods of above-normal conditions.
Five pairs of surface-water and ground-water sites were selected, and plots of cumulative monthly departures at these sites and a nearby NOAA precipitation station were developed to assess the decline and recovery that occurred during the 1998-2002 drought (table 8; figs. 27-31). The pairing of these sites does not necessarily imply that a given stream site and its companion ground-water well are hydrologically connected. However, the close proximity of the two sites presents an opportunity to better understand the hydrologic responses at each site to changing precipitation patterns recorded at the nearby precipitation station.

To assess the time lags at the beginning of the drought, cumulative

Table 8. Summary of time lags in cumulative monthly departures at selected surface-water and ground-water sites in response to changes in precipitation departures.

[Precip., precipitation; NOAA, National Oceanic and Atmospheric Administration; n/d; not determined. Number of months is time elapsed from month during which precipitation departures began to decrease or increase, indicating the onset or end of drought conditions, respectively. Distance is the straight-line distance between the surface-water and ground-water sites]

Surface-water, ground-water, and precipitation sites

French Broad River at Blantyre (site 126)

NC-144 at Blantyre (site 155

Precip. site: Asheville NOAA precipitation station

Distance: 0.35 mile

Long Creek near Paw Creek (site 106)

NC-146 at Hornets Nest Park (site 157)

Precip. site: Charlotte Douglas Airport NOAA

precipitation station

Distance: 2.0 miles

South Yadkin River near Mocksville (site 85)

NC-142 at Mocskville (site 159)

Precip. site: Mocksville 5 SE NOAA precipitation station

Distance: 7.0 miles

Drowning Creek near Hoffman (site 95)

NC-194 near Marston (site 162)

Precip. site: Fayetteville Public Works Commission NOAA

precipitation station

Distance: 6.5 miles

Trent River near Trenton (site 44)

NC-173 near Comfort (site 164)

Precip. site: Greenville NOAA precipitation station

Distance: 7.0 miles

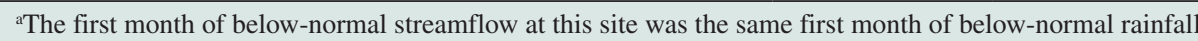
(May 1998), which was attributed to the small, more urbanized basin upstream from this site.

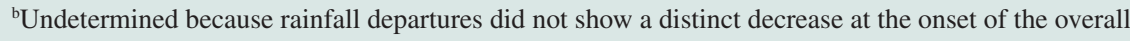
drought in 1998. 


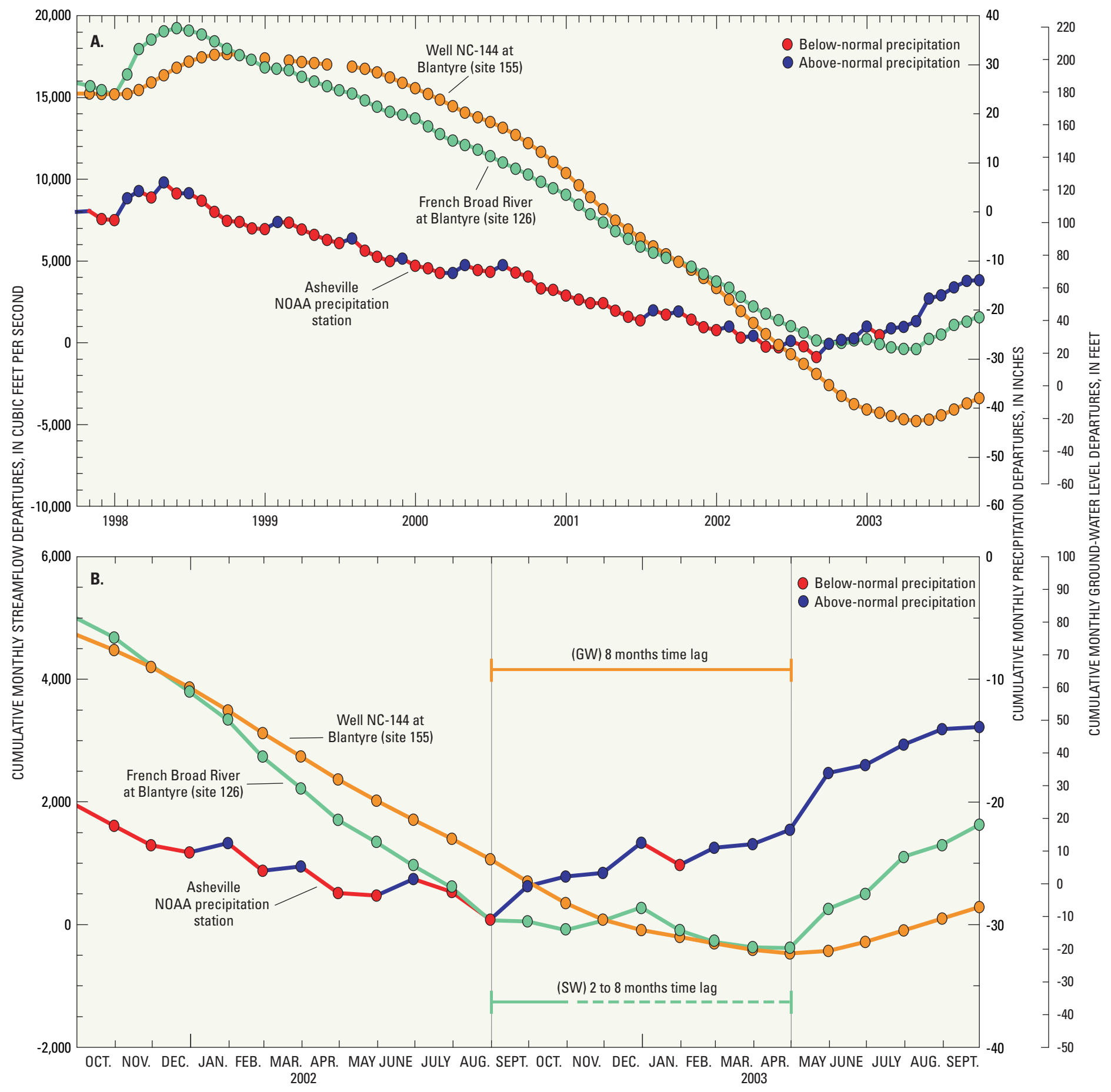

Figure 27. Cumulative monthly departures of streamflow, ground water, and precipitation for sites at Blantyre, Transylvania County, during (A) 1998-2003 water years and (B) 2002-03 water years. 


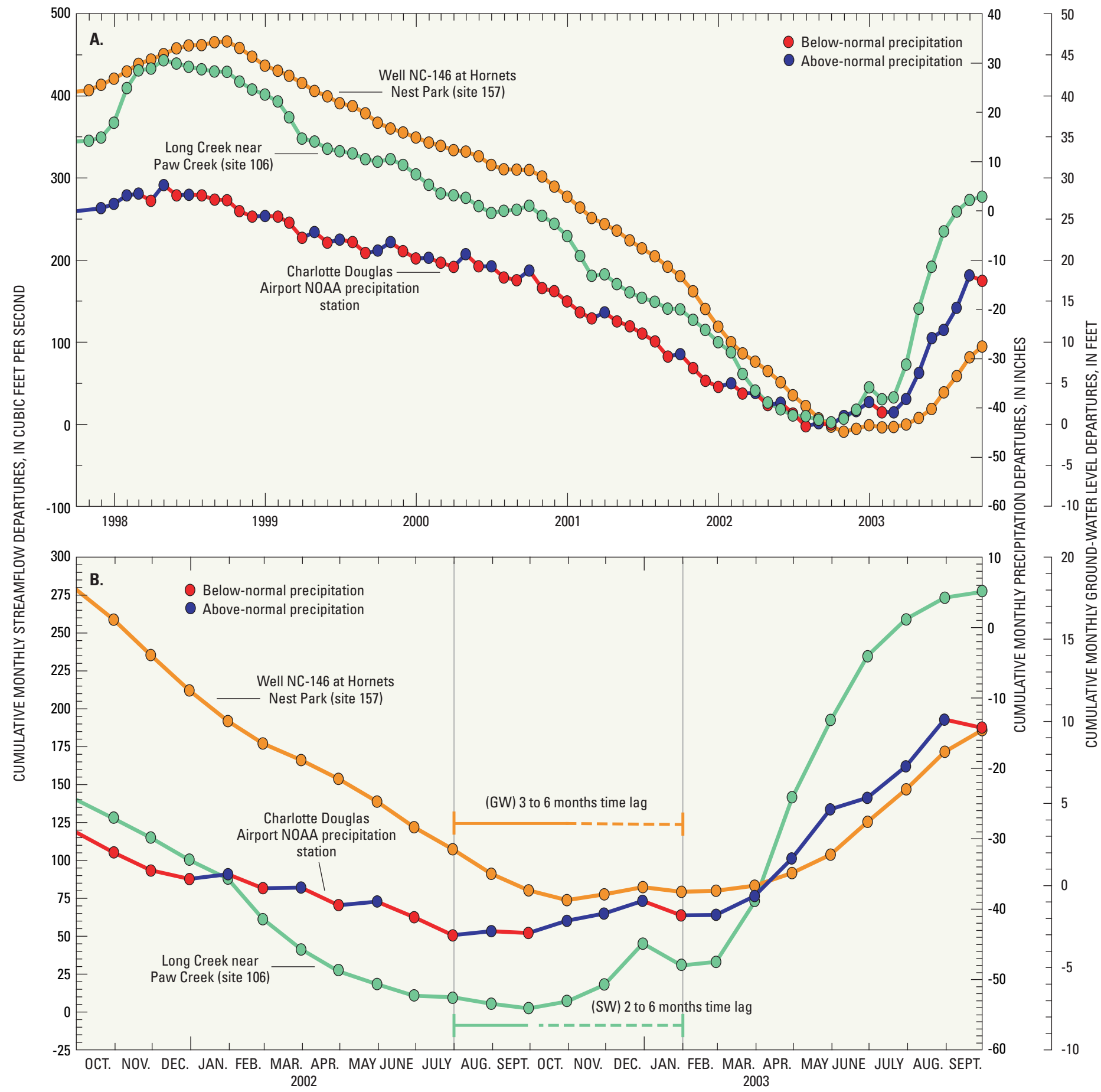

Figure 28. Cumulative monthly departures of streamflow, ground water, and precipitation for sites near Paw Creek, Mecklenburg County, during (A) 1998-2003 water years and (B) 2002-03 water years. 


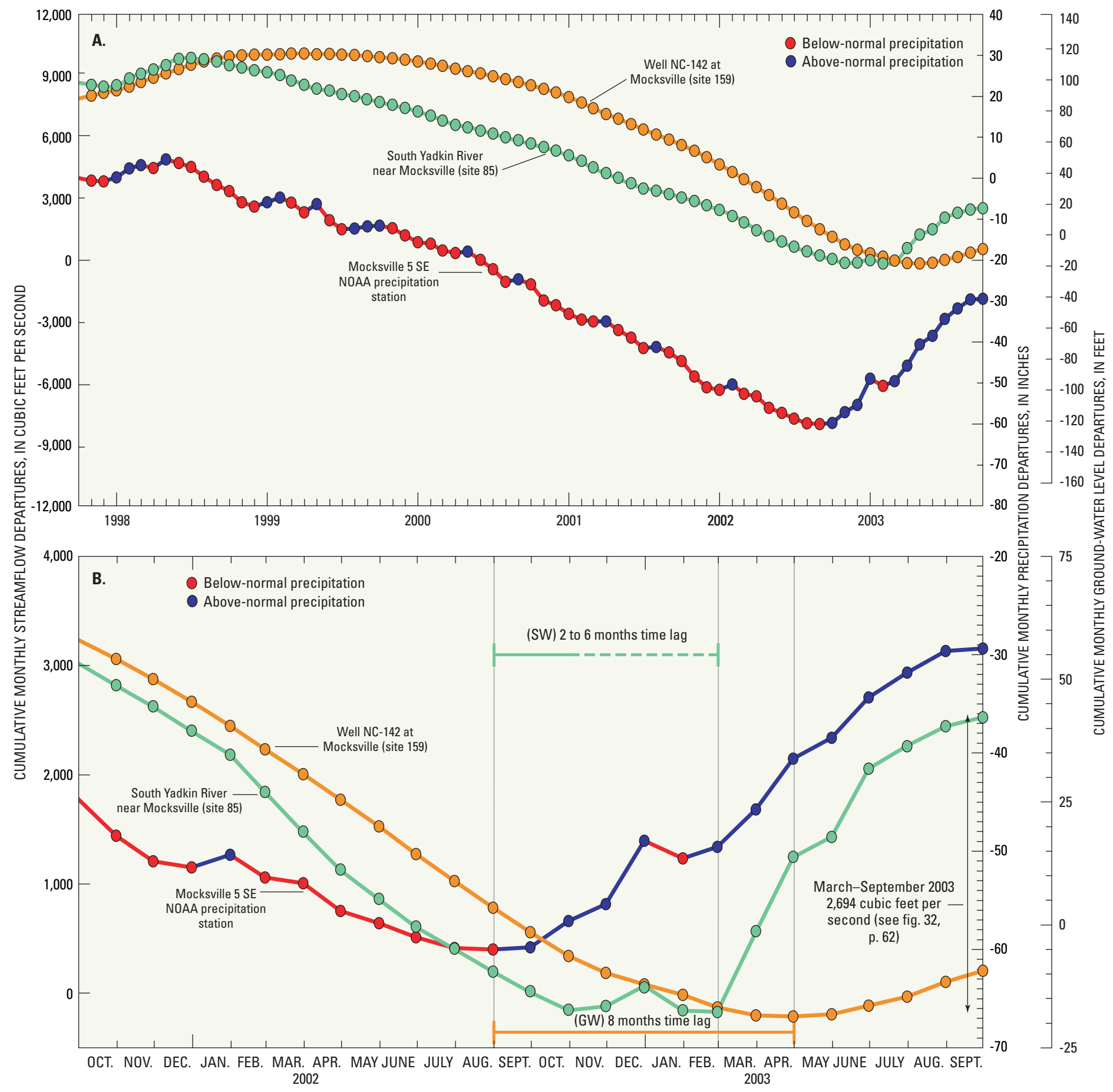

Figure 29. Cumulative monthly departures of streamflow, ground water, and precipitation for sites near Mocksville, Davie County, during (A) 1998-2003 water years and (B) 2002-03 water years. 


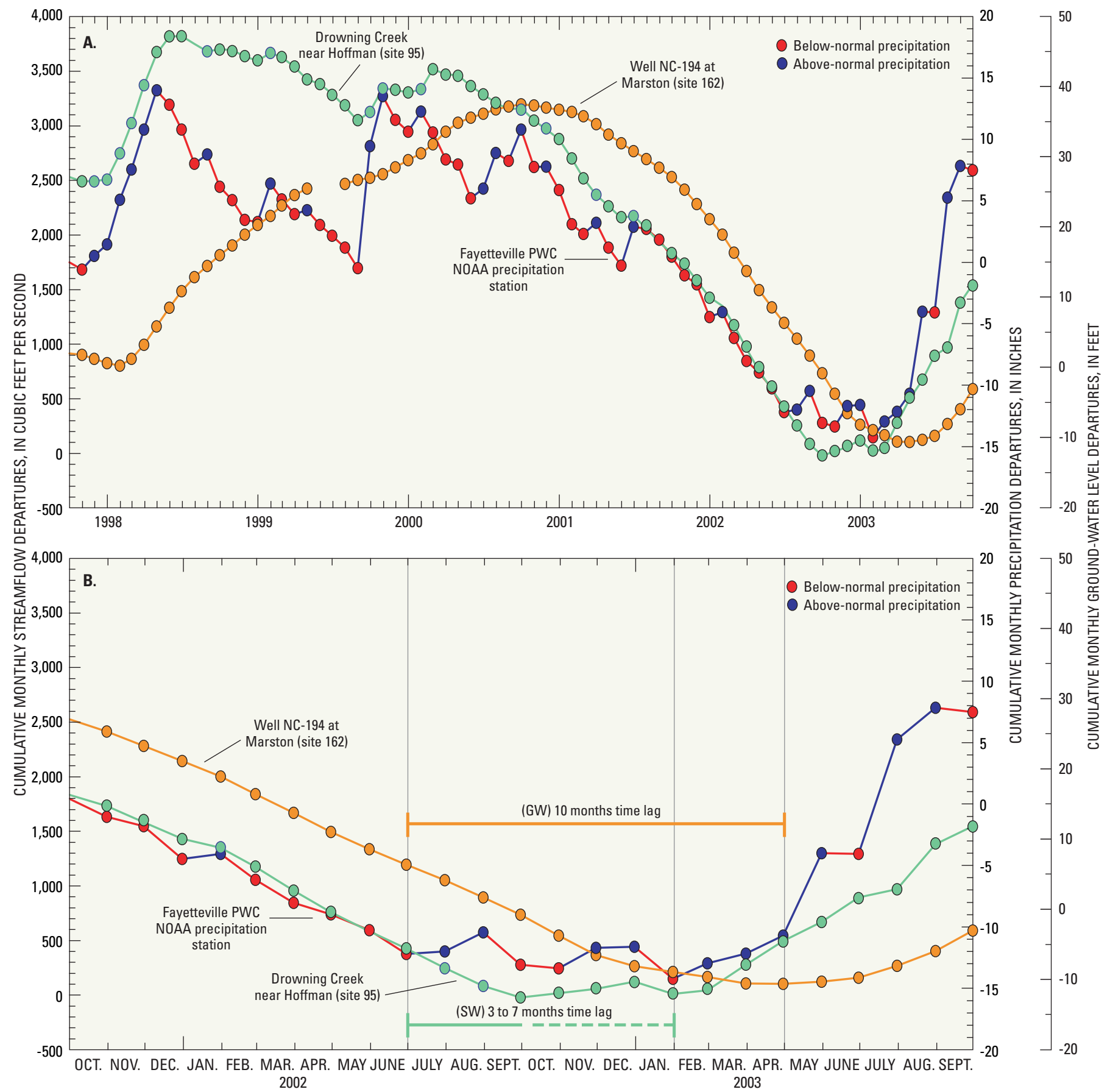

Figure 30. Cumulative monthly departures of streamflow, ground water, and precipitation for sites near Hoffman, Richmond County, during (A) 1998-2003 water years and (B) 2002-03 water years. 


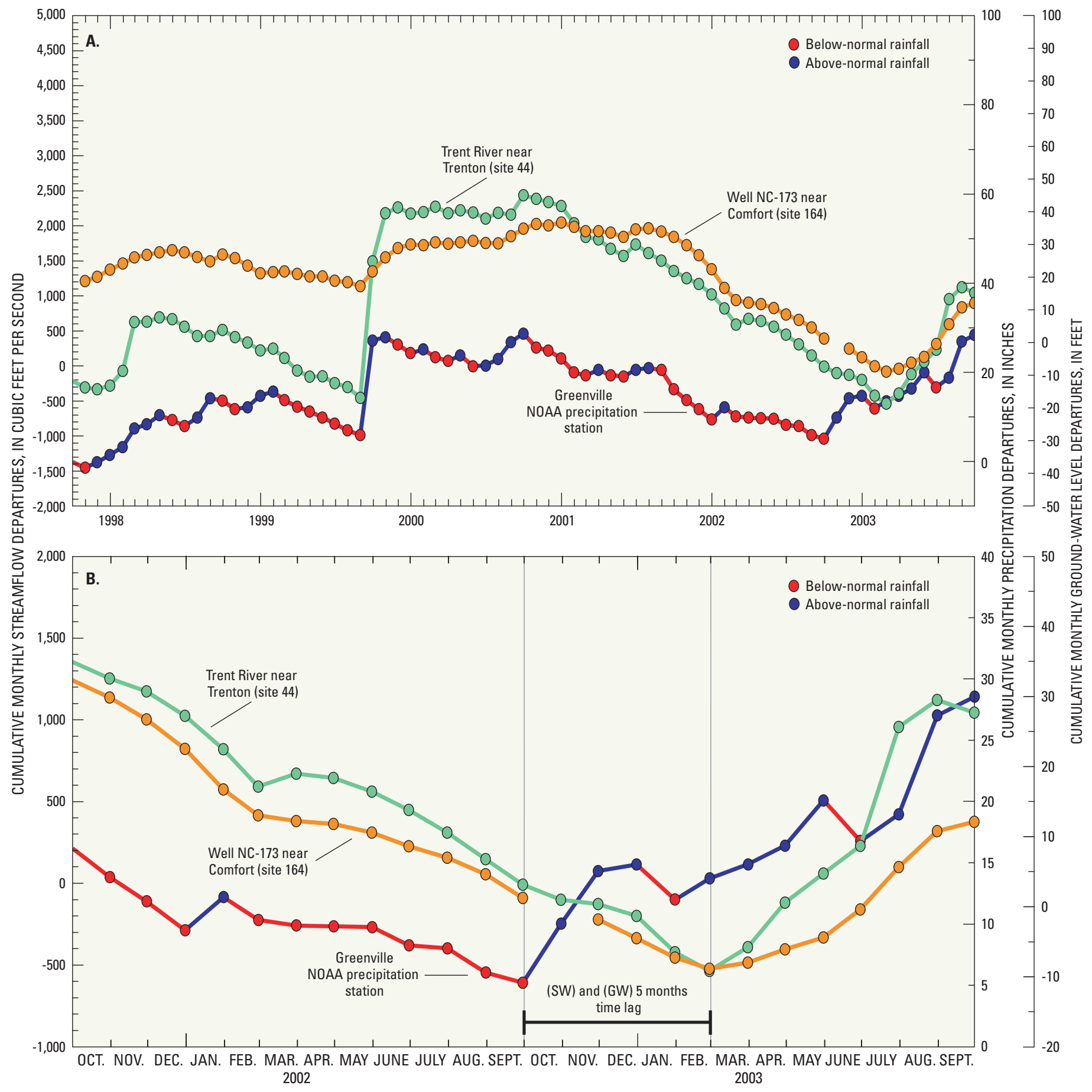

Figure 31. Cumulative monthly departures of streamflow, ground water, and precipitation for sites near Trenton, Jones County, during (A) 1998-2003 water years and (B) 2002-03 water years. 
monthly departures at the sites were examined to identify the time elapsed between the "peak" months for precipitation, streamflow, and ground-water departures (figs. 27-31). For instance, the last month of above-normal rainfall at the Asheville NOAA precipitation station was May 1998 (fig. 27), and the last month of above-normal streamflow (site 126) and ground-water levels (site $155)$ at Blantyre was in June (1 month) and October 1998 (5 months), respectively (table 8). Similar examinations were completed for the remaining four pairs of sites (figs. 28-31). To assess the time lags associated with drought recovery, the "trough" months in the departure curves were used to determine the time lags following the drought (figs. 27-31).

The onset of declining streamflow and ground-water levels as measured by cumulative monthly departures was much quicker and more distinctive for three of the five site pairs, all of which are located in the Piedmont or Blue Ridge Provinces (table 8; figs. 13, 19). Surface-water conditions began to decrease after 1 month at the French Broad River (site 126, fig. 27) and South Yadkin River (site 85, fig. 29); however, the first month of decreased streamflows was also the first month of below-normal rainfall at Long Creek (site 106, fig. 28). The quicker response at Long Creek is attributed to the smaller and more urbanized basin at this site.

At sites 95 and 44 in the Coastal Plain (figs. 30, 31), decreased streamflow conditions are more difficult to determine with certainty because of the variations in precipitation patterns that occurred during the 1998-2002 water years. Not until late 1999 and early 2000 did streamflow conditions begin to decrease consistently at these sites, and this pattern was not reversed until summer 2002 when above-normal rainfall patterns began to occur across North Carolina.

As drought recovery began in the latter half of 2002, time lags between the increase in precipitation and increases in streamflow varied from 2 to 8 months at sites 126, 106, and 85 (table 8; figs. 27-29) in the Piedmont and Blue
Ridge Provinces. The wide variations are a result of below-normal precipitation that occurred during January 2003, resulting in a brief period of belownormal streamflow at these sites. At sites 95 and 44 in the Coastal Plain (figs. 30, 31 ), the time lags in streamflow departures ranged from 3 to 7 months.

As expected, the time lags at the ground-water sites were longer than the time lags of monthly departures at the surface-water sites (table 8). This is consistent with the recognition that ground-water levels are the last component of the hydrologic system to respond to the start and end of droughts. At the three wells in the Piedmont and Blue Ridge Provinces, below-normal conditions, as denoted by the decreases in cumulative monthly departures, began 5 months (sites 155, 157) and 11 months (site 159) following the onset of belownormal precipitation (figs. 27-29). Just as downward trends in the two Coastal Plain surface-water sites were difficult to ascertain, time lags at the start of the drought also were difficult to discern for the two Coastal Plain wells (sites 162, 164; figs. 30, 31). Continuous downward trends in the monthly departures for these two wells did not begin until early and mid-2001.

At the end of the drought, increases in the cumulative monthly departures at the Piedmont and Blue Ridge wells began from 3 to 8 months after the start of above-normal rainfalls (table 8). At the Coastal Plain wells, the time lags in ground-water departures were 10 months (site 162) and 5 months (site 164).

\section{Assessment of 1998-2002 Drought Recovery Rate}

Drought recovery rates following the 1998-2002 drought and other historical droughts were compared for surface-water sites 85 and 131 to gain further insight into the degree of rapid recovery that appeared to occur during the 12-month period ending September 2003 (figs. 32, 33). Although individual monthly departures were positive for some months beginning in fall 2002, continuous above-normal conditions (as denoted by increases in the cumulative monthly departures) for these two streams did not begin until spring 2003. At each site, the number of months (through September 2003) during which cumulative monthly departures increased was determined, and the actual difference in cumulative streamflow departures was computed. Examination of the trend in monthly departures for South Yadkin River (site 85) indicates that the first month of increased streamflow was March 2003; by September 2003, streamflow had increased by about 2,690 $\mathrm{ft}^{3} / \mathrm{s}$ (figs. 29, 32). The precipitation departure also was identified for the same 7-month period. Next, to facilitate a comparison, the numbers of months following selected historical droughts during which almost the same amount of increased streamflow occurred also were computed. At South Yadkin River, an increase of about $2,700 \mathrm{ft}^{3} / \mathrm{s}$ in the streamflow departures occurred during a 23-month period from February 1971 through December 1972 following the 1960s drought (fig. 32). Similar determinations were made for the periods following the 1950s and 1980s droughts. Among the four drought recovery periods, the rate of recovery in 2003 on South Yadkin River was much quicker in response to a greater amount of precipitation.

Similar comparisons of the recovery rates following historical droughts on the French Broad River (site 131) also indicated a strong and quick recovery following the 1998-2002 drought. During the 6 months from April through September 2003, the cumulative streamflow departures increased about 6,750 ft³ $/ \mathrm{s}$ (fig. 33). However, recovery rates of similar magnitudes occurred during shorter periods (5 months) following the droughts of the 1920s and 1980s. A similar drought recovery rate occurred following the 1950s drought but over a longer period (57 months).

The time lags observed during recovery of hydrologic conditions following the 1998-2002 drought cannot be considered typical of recovery periods following droughts because of the continuous above-normal precipitation that occurred during the 
12-month period ending September 2003. Had precipitation during these 12 months been consistently closer to normal values, the recovery period would have extended well beyond spring and summer 2003. Defining a typical recovery is difficult because of many factors that affect the period of time in which hydrologic conditions return to normal ranges. In addition to precipitation amounts, drought recovery is influenced by the season and by infiltration characteristics of soils. Soils vary across North Carolina's physiographic provinces and allow water to infiltrate from the surface to the ground-water system at different rates. The seasons influence the evaporative and consumptive rates of water, which in turn, affects the amount of water available for replenishing the hydrologic system. Thus, the recovery following the 1998-2002 drought can be regarded as the ideal recovery sought by a drought-weary region adversely affected by the drought's effects. Much of the replenishing precipitation following the 19982002 drought occurred from fall through spring when water demands typically are low and when lower evaporation rates occur.

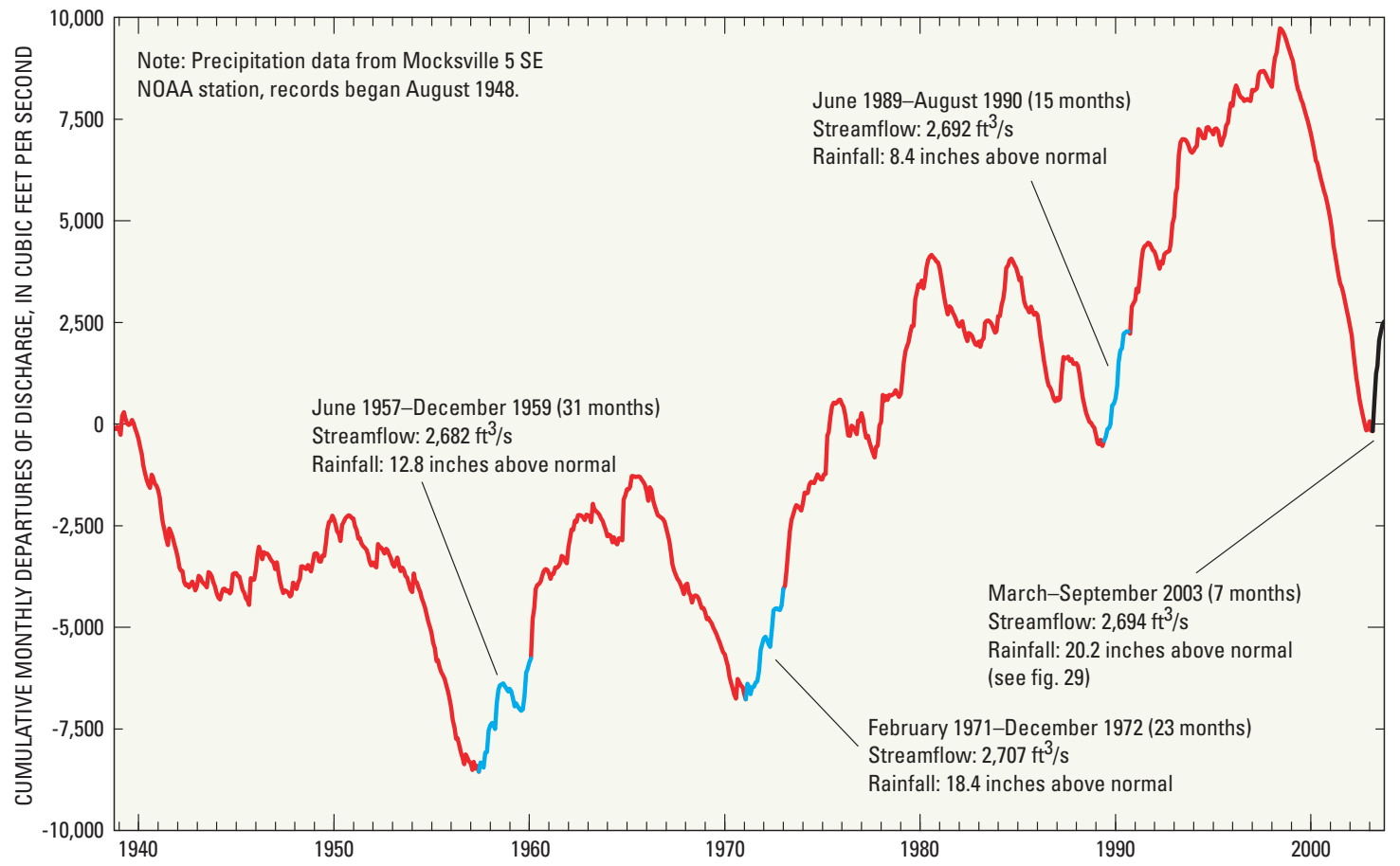

Figure 32. Drought recovery rates at South Yadkin River near Mocksville (site 85) using cumulative monthly streamflow departures from October 1938 through September 2003.

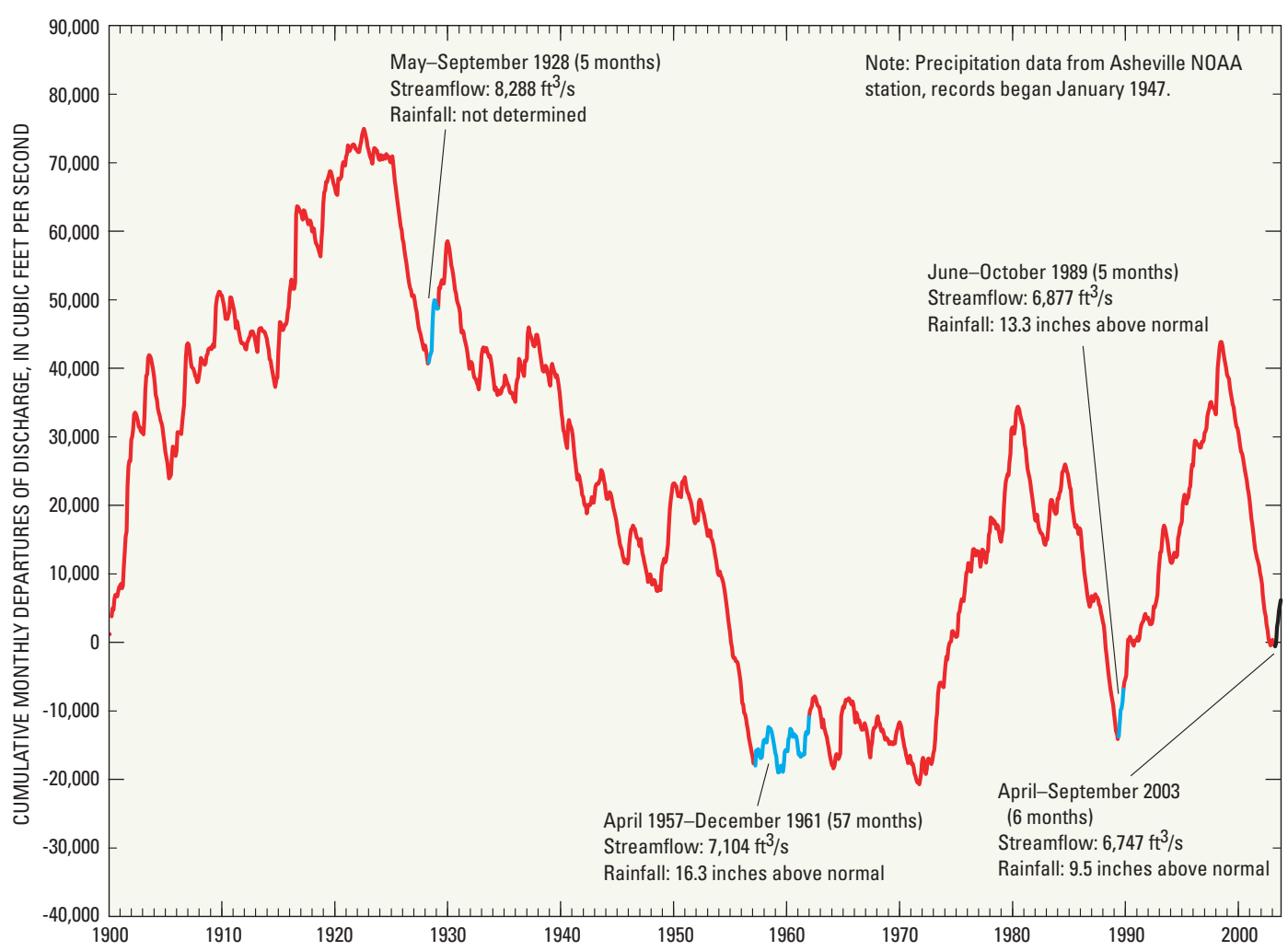

Figure 33. Drought recovery rates at French Broad River at Asheville (site 131) using cumulative monthly streamflow departures from January 1900 through September 2003. 


\section{Societal Effects of the 1998-2002 Drought in North Carolina}

The effects of the 1998-2002 drought appear to be greater than those of previous documented droughts in North Carolina. Most of the effects, however, were not a source of great concern to the general population until early 2002 after two dry winters (2001 and 2002) occurred in combination with a very dry spring across the State and exacerbated the drought conditions. The primary threats were to water supplies, as many watersystem customers were forced to conserve water, and well owners either lost supply as wells went dry or came extremely close to doing so. The effects documented on the accompanying time line, which spans from January 2002 through June 2003, are selected highlights of problems caused by the drought and actions taken and should not be considered a complete description of the effects on communities and populations across North Carolina.

Residents of North Carolina and much of the eastern United States historically have benefited from an abundance of water. Thus, one of the challenges facing the NCDMAC and water-supply systems was to educate the citizens about limited water supplies and the need to adopt conservation measures during a period of declining supplies. As one State official later recalled, when towns in the normally "wet and flush" Sand Hills region (including Moore County) began to experience water-supply shortages, the severity of the drought took on a greater degree of urgency (Mr. Woody Yonts, North Carolina Department of Environment and Natural Resources, oral commun., April 1, 2004).

During the first half of 2002, about 25 communities implemented varying levels of water conservation in response to decreasing water supplies. By late September 2002, following the height of the drought, almost 250 municipalities and communities across the State had implemented voluntary, mandatory, or emergency conservation procedures (fig. E-1).

Emergency conservation restrictions were imposed when insufficient or complete loss of supply posed immediate threats to communities, requiring drastic and unusual measures to maintain sufficient supplies. The most serious threats to water supplies were confined primarily to communities in the Piedmont region where drought conditions persisted continuously during the 4-year drought. The critical shortages of water in some towns fostered an atmosphere of quick thinking and ingenuity on the part of

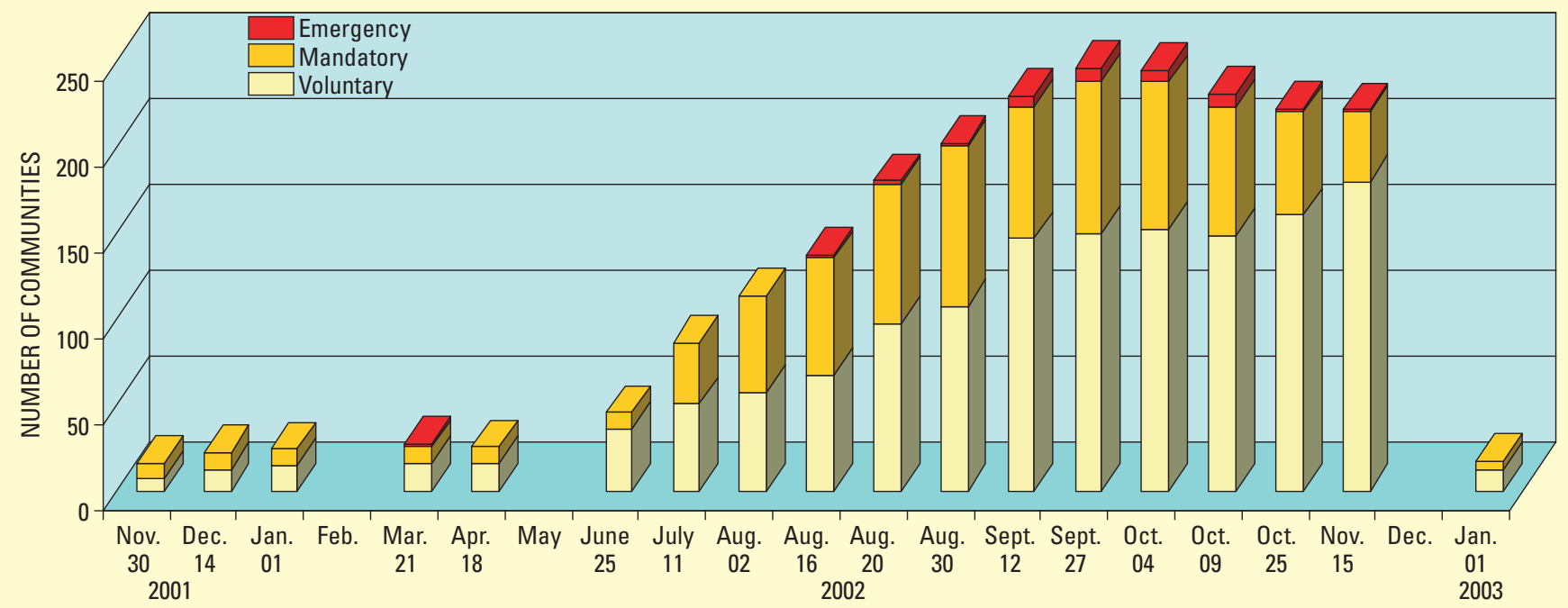

Figure E-1. North Carolina communities operated under mandatory, voluntary, or emergency water conservation from November 2001 through January 2003. (No data were available for February, May, and December 2002; adapted from data provided by Mr. Woody Yonts, North Carolina Department of Environment and Natural Resources, written commun., April 1, 2004.) 


\section{Time line from January 2002 through June 2003 showing s drought and the subs}

Downstream flows in the lower Cape Fear River (below B. Everett Jordan Lake) were insufficient to prevent the encroachment of a saltwater wedge upstream from the Cape Fear River estuary during tidal fluctuations. The presence of the saltwater wedge, particularly during summer 2002, caused significant challenges in the operation at a paper manufacturer in Columbus County.
Shelby, in Cleveland County, implemented emergency conservation in August 2002. The First Broad River reached such low levels that the city obtained water from a neighboring water-supply system (owned by Kings Mountain) by improvising a transfer system using fire trucks and hoses to pump water from fire hydrants located where the two distribution systems were a short distance from each other (see photo on $p .63$ )

Northeast of Shelby, available water supply for Cherryville fell to levels equivalent to about 1 day's supply in August 2002, prompting the town to search for water in nearby farm ponds and set up an emergency connection to Lincoln County's water supply to obtain enough water to meet basic demands.

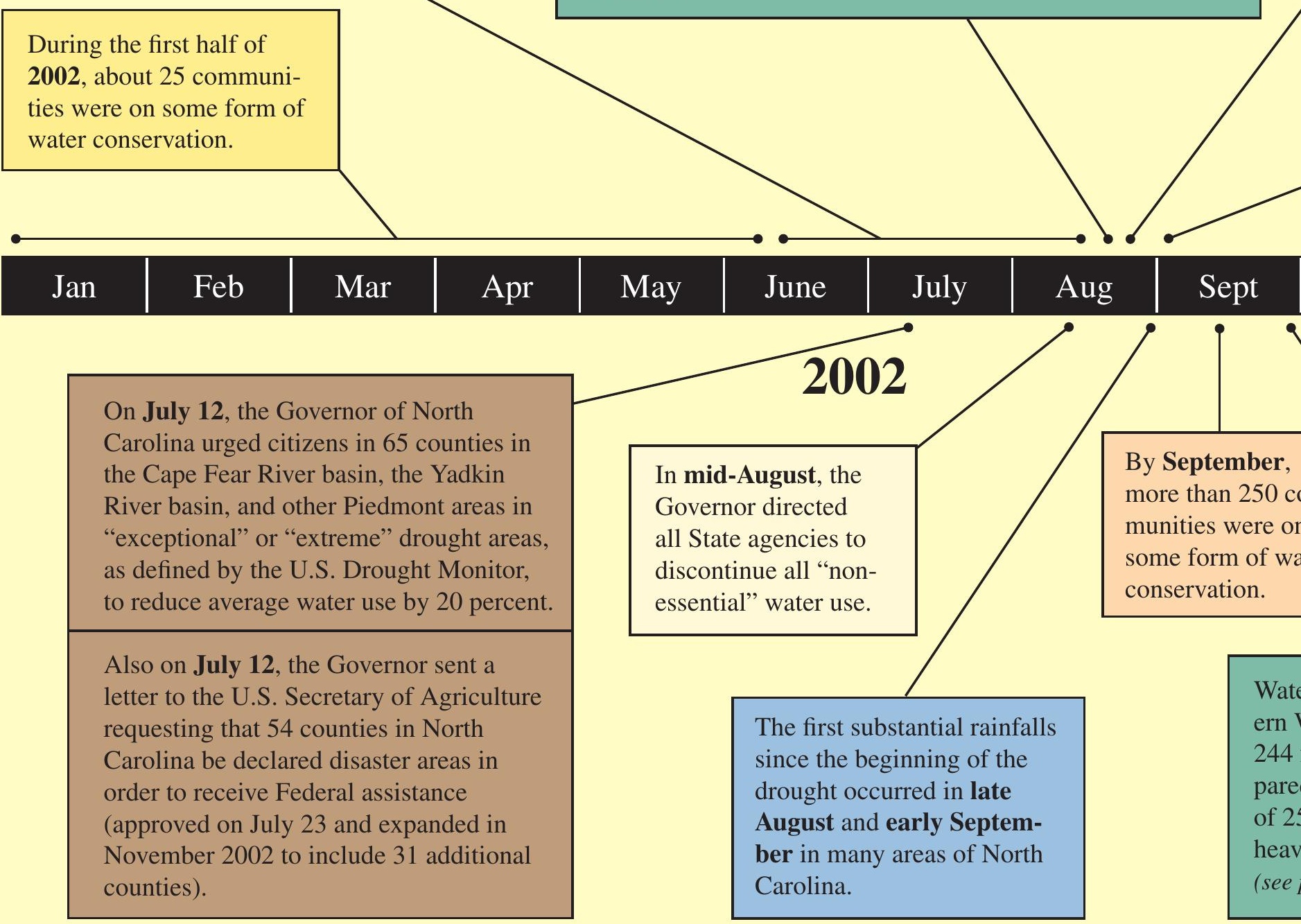


rely on streams within the same basin for water supply (Knight Publishing Company, 2002).

Even with the onset of wetter conditions in late August and September 2002, the number of communities practicing water conservation remained above 200 through November when many systems under mandatory conservation switched to voluntary conservation (fig. E-1). By January 2003, above-normal precipitation provided enough improvement to water supplies that the total number of communities under some form of water conservation decreased more than 90 percent from peak levels in September 2002.

Even large reservoirs across North Carolina that serve multiple purposes had record or near record-low water levels, resulting in continuous and careful management to balance the upstream and downstream needs of users. Waterconservation efforts were in effect at Lake Norman, the largest of 11 impoundments located along the heavily regulated Catawba River in North and South Carolina. In the first months of the 1998-2002 drought, the regional power utility that owns the lake put conservation measures in place to save the surplus lake volume generated by abovenormal precipitation in winter and spring 1998. Such water-saving measures included coordinating lower (40-percent reduction) reservoir releases with downstream industries and utilities. Monthly inflows to some large reservoirs operated by the U.S. Army Corps of Engineers were among the lowest recorded since the impoundments were constructed. At B. Everett Jordan Lake in Chatham County, monthly inflows were less than 50 percent of monthly normals in 17 of 24 months (October 2000 through near the North Carolina-Virginia State line, inflows were below the lowest monthly records since 1950 in 8 of the 12 months between October 2001 and September 2002.

One of the purposes of J.H. Kerr Reservoir, located on the North CarolinaVirginia State line, is for hydroelectric

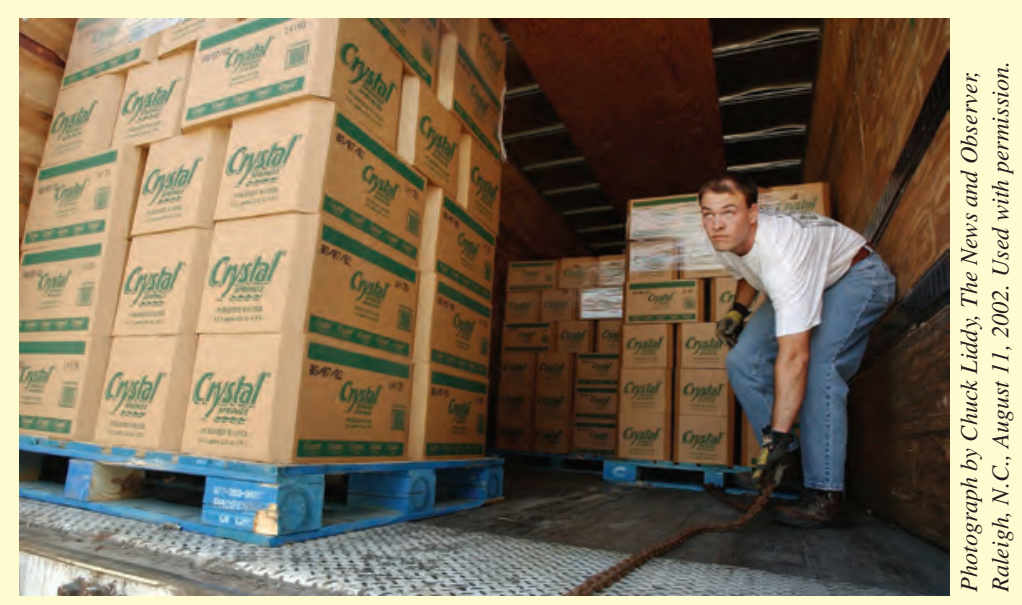

A volunteer firefighter unloads a pallet of bottled water in Vass, N.C. The Division of Emergency Management delivered 5,800 gallons of water to the town in August 2002.

September 2002) and declined to less than 15 percent from May through July 2002 (fig. E-2). During the same period, monthly inflows to Falls Lake in Wake and Durham Counties were less than zero in 5 of 24 months (including May through July 2002), which means the monthly volume of water that evaporated from the lake exceeded inflows from the basin. At J.H. Kerr Reservoir power production, which posed additional challenges in maintaining all uses of the impoundment. During the latter stages of the drought, normal power production could not be achieved, and replacement power had to be purchased to meet demands. During the 1998-2002 drought, the cost of replacement power was about \$1.3 million (Mr. Carter Edge, Southeastern Power Administration,

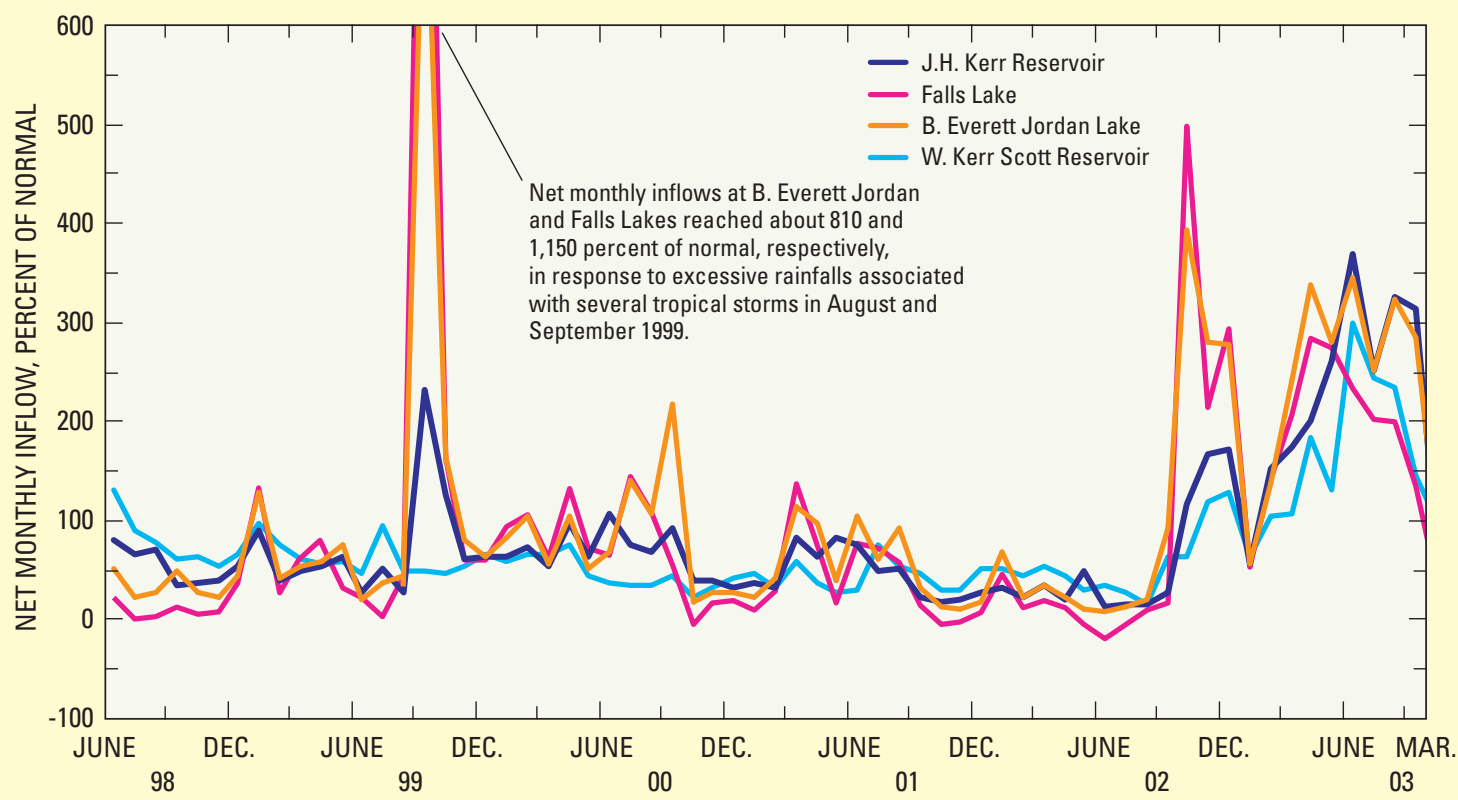

Figure E-2. Net monthly inflows from July 1998 through March 2003 at four reservoirs in North Carolina and Virginia (adapted from data provided by Mr. Terry Brown, U.S. Army Corps of Engineers, written commun., April 8, 2004). written commun., April 9, 2004), a cost ultimately borne by customers.

Estimates of the effects of droughts on the economy are often difficult to establish, and little has been done by businesses and government to track the costs associated with droughts. When major droughts occur, the large-scale efforts needed to assemble such information from a wide spectrum of affected sectors and geographic areas typically hinder the identification of costs, particularly when such data are not easily distinguished from the overall costs of operation and production. The economic effects of droughts vary widely from seemingly small increased for homeowners 
costs to irrigate parched lawns and gardens to the much greater costs associated with agricultural losses. For example, the low water volumes in Lake Don T. Howell, the primary water supply for Cabarrus County, throughout most of the 1998-2002 drought resulted in the implementation of mandatory water conservation in Concord from February 2000 through mid-November 2003. During this period, the city issued 341 citations for water violations, totaling $\$ 91,600$ (Ms. Joyce Allman, City of Concord, written commun., April 13, 2004). In neighboring Mecklenburg County, the implementation of mandatory water conservation resulted in 1,985 citations being issued from mid-August through November 1, 2002, totaling about $\$ 50,000$ in water-violation fees (Ms. Maeneen Klein, Charlotte-Mecklenburg Utilities Department, oral commun., April 12, 2004). Other economic effects included decreased municipal revenues from the sale of water supplies and from limited recreational opportunities at area lakes because of lower water levels.

While economic losses are associated with droughts, there are some economic gains associated with droughts. Companies that focus on water production or on providing alternative water use typically experience higher demands for services, such as well-drilling companies, irrigationsystem companies, and commercial car-wash businesses, especially in areas where personal car washing is prohibited or restricted because of mandatory waterconservation measures.

In 1995, the Federal Emergency Management Agency (FEMA) estimated that droughts in the United States cause an average annual loss of $\$ 6$ to $\$ 8$ billion, surpassing the annual average losses associated with floods and hurricanes $\$ 2.41$ billion and $\$ 1.2$ to $\$ 4.8$ billion, respectively; Federal Emergency
Management Agency, 1995). In general, the costs associated with specific droughts are not available. The drought across the United States in 1988-89, however, was estimated to cost nearly $\$ 40$ billion, with a large part of the reported losses coming from the agricultural sector (National Drought Mitigation Center, 2003b). To encourage the estimation of economic effects of droughts, the NDMC compiled information for 2002 and determined an approximate cost of $\$ 11$ billion (Hayes and others, 2004). However, data were not available from all states affected by the drought in 2002, nor were data available from all affected sectors within states for which cost information was compiled. Thus, the $\$ 11$ billion cost is considered an underestimate.
In North Carolina alone, drought costs in 2002 were estimated to be $\$ 398$ million for agriculture and $\$ 15$ to $\$ 20$ million for municipalities (Hayes and others, 2004). It should be noted that these costs are for only 1 year of the 4-year drought and do not include costs associated with business and industry losses. The North Carolina Rural Economic Development Center cited drought costs at $\$ 1$ billion, although no specific information was given on which sectors were represented in this estimate (Hall, 2003). The lack of complete costs for all affected sectors has highlighted the need for additional emphasis on tracking costs associated with droughts (Hayes and others, 2004).

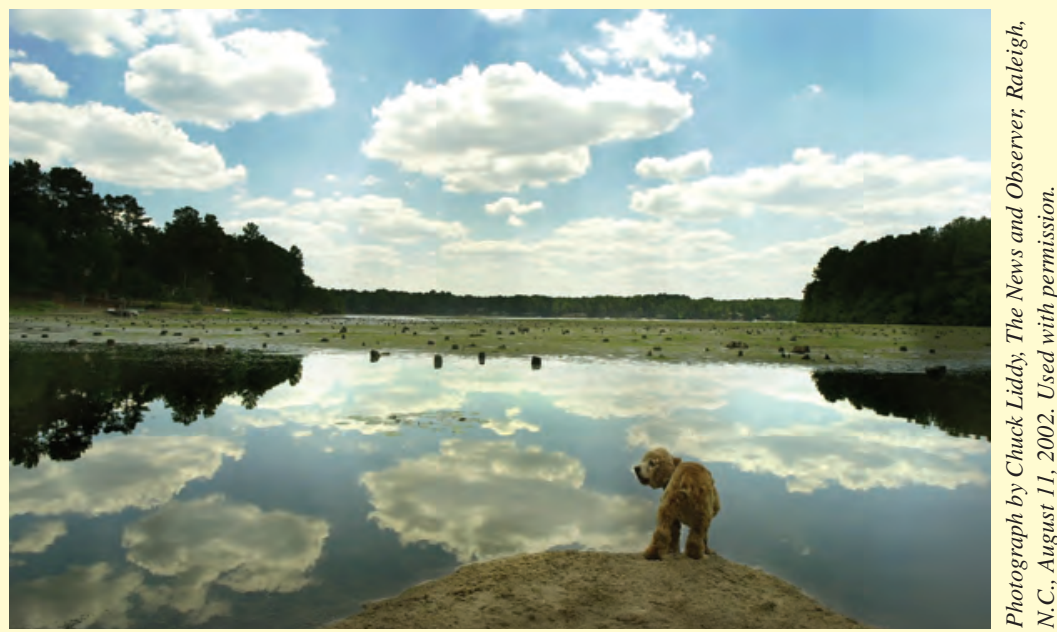

Thaggard's Lake, in Moore County, was used as an emergency water supply for the town of Vass in August 2002.

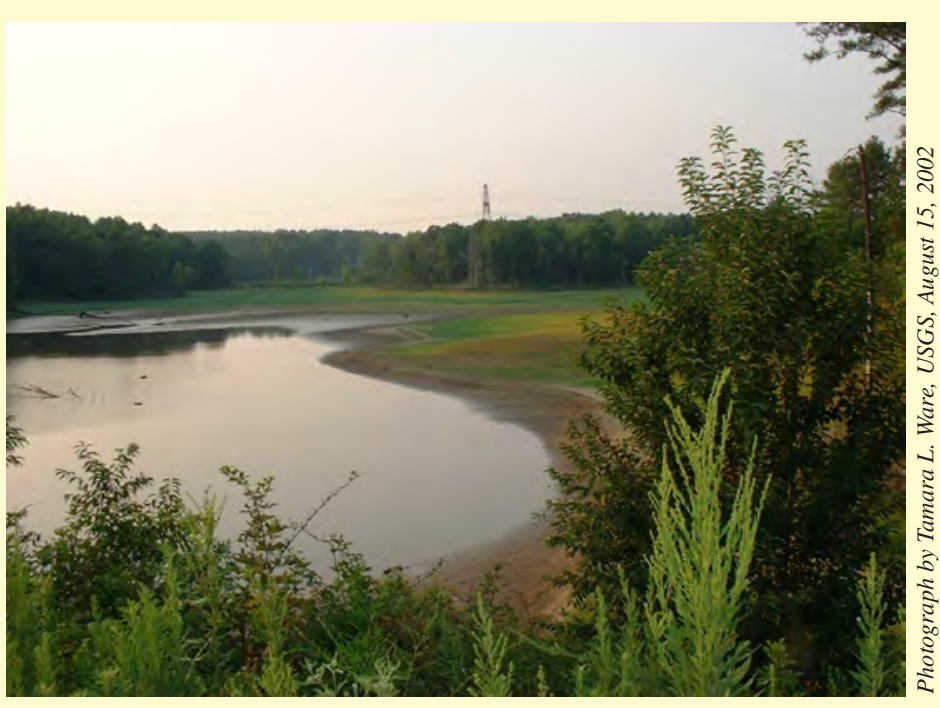

Falls Lake, in northern Wake County, was 6 feet below its normal operating level in August 2002. 


\section{Summary}

rought conditions prevailed
across much of North

Carolina during 1998-2002, resulting in widespread record-low streamflow and ground-water levels in many areas, particularly in 2002. During this 4-year period, the drought was continuously present in areas of western North Carolina; eastern areas of the State had some periods of relief from the drought from tropical storms in 1998 and 1999. The occurrence of dry winters in 2001 and 2002 followed by a dry spring exacerbated drought conditions across the State during the summer of 2002.

Precipitation deficits during the 1998-2002 drought were among the highest recorded for some locations in North Carolina. The largest deficits occurred primarily in the western Piedmont and reached 60 to 70 inches at some locations during the 4-year period. Record rainfalls from several tropical storms in late August through October 1999, most notably Hurricane Floyd, caused widespread catastrophic flooding that brought immediate but temporary relief from drought conditions in much of eastern North Carolina. Cumulative monthly precipitation at 13 selected NOAA precipitation stations across the State ranged from 5.3 inches below normal (Greenville) to 66.7 inches below normal (Hickory) from May 1998 through September 2002. At 9 of the 13 stations, precipitation deficits during the drought were more than 25 inches below normal. At three of these locations (Hickory, Charlotte, and Mocksville), precipitation deficits exceeded the average annual precipitation. Expressed another way, the equivalent of between 12 and 18 months of precipitation did not occur at these locations during the 4-year drought.

Available data for the period of record were examined for 8 of the 13 NOAA precipitation stations to compare the deficits during the 1998-2002 drought with those that occurred during selected historical droughts. For instance, the deficit of 68.3 inches at Hickory from May 1998 through July
2002 (51 months) exceeded the deficit of 60.0 inches over 82 months during the 1950s drought, which lasted from late 1949 through 1957 and was commonly regarded as the benchmark drought prior to the 1998-2002 drought. However, this was not the case at all locations; thus, an average monthly deficit was computed for the historical droughts at the eight selected sites to serve as a simple index for comparing rainfall deficits among the droughts.

At three (Hickory, Charlotte, and Mocksville) of the eight locations, the average monthly rainfall deficit exceeded the values computed for other drought periods. While the 1998-2002 average monthly deficits were not the largest for the remaining five locations, the 1998-2002 values would have been the maximum values at three locations (Greensboro, Raleigh, and Fayetteville) where the actual deficits were skewed by rainfall from tropical storms (Hurricanes Dennis, Floyd, and Irene) in fall 1999. After rainfall record was adjusted to exclude the rainfall during August, September, and(or) October at Greensboro, Raleigh, and Fayetteville, the adjusted average monthly deficits for these locations were then the largest values identified among the drought periods.

Of the 211 continuous-record streamflow-gaging stations across North Carolina in the 2002 water year, record-low annual mean discharge and daily mean discharge were set at 150 and 121 sites, respectively, during the 1998-2002 water years. Of these sites, annual and daily records were set at 131 and 94 sites, respectively, during the 2002 water year alone. Record daily mean discharges before and after the drought were compiled for 150 of the 211 gaging stations where periods of record exceeded 10 years. Among these 150 sites, records of low daily mean discharge were set at 65 sites during the 4-year drought (55 sites during the 2002 water year alone).

The 150 sites were re-examined to identify the sites having 30 years of uninterrupted record through the 2002 water year and no significant effects from regulation and(or) diversions. The resulting subset of 68 sites were then analyzed to quantify the "daily" percentile and recurrence intervals of 7-day average discharges. For the purposes of characterizing streamflow conditions in smaller areas, the 68 sites were subdivided into 6 groups representing smaller areas of each physiographic province: 13 sites in the southern Blue Ridge, 11 sites in the northern Blue Ridge, 14 sites in the western Piedmont, 19 sites in the eastern Piedmont, 7 sites in the southern Coastal Plain, and 4 sites in the northern Coastal Plain.

During May 1998, the first month in which rainfall amounts were below normal, streamflows began a gradual decline to levels that were in the lower ranges of normal (defined as 25th through 75th percentiles) by September for Piedmont streams. Streamflow conditions in the Blue Ridge Province declined further into the 10th-24th and $<10$ th percentiles during the same period. Southern Blue Ridge streams generally had the highest number of days in which the 7-day average discharge exceeded the 10-, 50-, and 100-year recurrence intervals, and some sites exceeded the 10-year recurrence interval for more than 50 days.

Overall streamflow conditions during much of the 1999 water year were in the lower ranges of normal and the 10th-24th percentiles, although streams in the eastern Piedmont and Coastal Plain were in the high-percentile ranges ( $>90$ th percentile) because of tropical storms. Among the 68 sites for which detailed analyses were completed, about 15 sites across the State had more than 100 days during which 7-day average discharges were in the $>10$-year recurrence interval range.

During the first half of the 2000 water year, the Coastal Plain and eastern Piedmont streams gradually declined from above normal (75th percentiles and higher) to the low-normal range following the flooding that occurred from Hurricane Floyd. In the western Piedmont and Blue Ridge Provinces, streams generally were between the low-normal range and the 10th-24th percentiles throughout most of the 2000 water year. 
Throughout much of the 2001 water year, overall streamflows were more consistently in the below-normal range ( $<10$ th and 10 th-24th percentiles) in all three provinces. The number of days in which 7-day average discharges exceeded the 10-, 50-, and 100-year recurrence intervals continued to increase significantly in the Blue Ridge and western Piedmont. In particular, the 7-day average discharges exceeded the 10-year recurrence interval at about 15 sites in this area for more than 200 days and at one site for more than 300 days.

Streamflow conditions continued to decline during the 2002 water year and by August and September reached the lowest levels since the beginning of the drought. Across most of North Carolina, streamflows consistently were in the $<10$ th percentile range, and new record-low flows (for the calendar day) were being set on an almost daily basis. Recurrence intervals for 7-day average discharges varied across the State, and many streamflows were in the 50- to 100-year recurrence interval range during the summer months until abovenormal rainfalls arrived in late August and September to reverse the low-flow trends. During the 2002 water year, the areal extent of sites where 7-day average discharges exceeded the 10-year recurrence interval for more than 200 or 300 days covered much of central North Carolina. In fall 2002, streamflows began to consistently increase at many sites across North Carolina for the first time in nearly 4 years.

During October 2002 through June 2003, streams generally returned to normal and above-normal levels (75th-89th percentiles). Following a brief decline during January, streamflow conditions continued to improve to higher levels between February and June, and levels consistently were in the 75th-89th and $>90$ th percentile ranges. In fact, during the 2003 water year, none of the 68 sites used in this analysis had more than 50 days in which the 7-day average discharges exceeded the 10-, 50 -, or 100-year recurrence intervals. Another indication of the rapid reversal in streamflow conditions during the 2003 water year is the occurrence of record-high annual mean discharges that were established at 130 of 214 continuous-record gaging stations across North Carolina. Of the 130 gaging stations, 87 were sites where record-low annual mean discharges were set during the 2002 water year, including 19 of the 68 selected gaging stations analyzed for this study. In terms of streamflow, drought conditions were considered nonexistent by the end of April 2003.

Comparisons of minimum 7-day average discharges for six selected gaging stations (two from each physiographic province) with long-term records provided insight into how the 1998-2002 drought compares with historical droughts in North Carolina. The minimum 7-day average discharge was determined for each historical drought documented in North Carolina. At three sites, the minimum 7-day average discharges during the 1998-2002 drought became the minimum flows for the periods of record, including the site on the French Broad River in western North Carolina having the longest period of record. Because the three sites are located in the Piedmont and Blue Ridge Provinces, these comparisons confirmed observations that the greatest effects of the 1998-2002 drought occurred at streams in these areas of North Carolina.

Ground-water levels were measured in 137 observation wells across North Carolina in the 2002 water year. Of these wells, 96 were operated to monitor the effects of human-induced stresses (namely, ground-water withdrawals) on the ground-water system, and 41 wells were operated to monitor changes in ground-water storage in response to climate changes. Examination of the ground-water data at sites having at least 5 years of record through the 2002 water year indicates that new record-low water levels for the periods of record were set at 45 of these wells. The spatial distribution and periods of record for USGS observation wells having long-term continuous records in North Carolina are smaller relative to those in the network of surface-water sites. Only 5 of the 41 climate-response wells had greater than 20 years of continuous record in the 2002 water year. Examination of ground-water records collected by the USGS and North Carolina Division of Water Resources resulted in the selection of 21 climate-response wells that were spatially distributed across the state. Three of these sites are deep wells in the Blue Ridge and western Piedmont and are used to measure water levels in the underlying bedrock; the remaining 18 relatively shallow wells are used to measure water-level fluctuations in the surficial aquifer.

Record-low water levels were set at 13 of the 21 selected wells during the 1998-2002 water years; records were set at 11 of the 13 sites during the 2002 water year alone. Where new record-low water levels were set during the 1998-2002 drought, the difference between the pre-drought and new records ranged from 0.05 to $2.85 \mathrm{ft}$ among the 13 wells.

Drought recovery rates following the 1998-2002 drought and other historical droughts were compared using cumulative monthly streamflow departures for two surface-water sites (South Yadkin River and French Broad River) to gain further insight into the type of recovery that occurred during the 12-month period ending September 2003. For instance, examination of the trend in monthly streamflow departures for South Yadkin River indicates that overall increases began during March 2003 and by September 2003 (a 7-month period) had increased by approximately $2,690 \mathrm{ft}^{3} / \mathrm{s}$. In comparison, a drought recovery rate of similar magnitude at this site occurred during a 23-month period from February 1971 through December 1972 following the 1960s drought. Similar comparisons of the recovery periods following historical droughts on the French Broad River also indicated a strong and rapid recovery following the 1998-2002 drought. During the 6 months from April through September 2003, cumulative monthly streamflow departures increased by about $6,750 \mathrm{ft}^{3} / \mathrm{s}$. However, recovery rates of similar magnitudes occurred during shorter periods (5 months) following the droughts of the 1920s and 1980s. A similar drought recovery rate 
occurred following the 1950s drought but over a longer period (57 months).

The time lags observed during recovery of hydrologic conditions following the 1998-2002 drought cannot be considered typical of recovery periods following droughts because of the above-normal rainfalls that occurred during the 12-month period ending September 2003. Had rainfall during these 12 months been consistently closer to normal values, the recovery period would have extended well beyond spring and summer 2003.

Record or near record-low water levels occurred at reservoirs across North Carolina, including some of the largest ones used for multiple purposes, and continuous and careful operation was necessary to balance upstream and downstream user needs. Lake Don T. Howell, the primary water supply for Cabarrus County, remained below full capacity for almost 5 years (March 1998 through March 2003), falling to $10.1 \mathrm{ft}$ below full capacity on October 10, 2002. Monthly inflows to some large reservoirs operated by the U.S. Army Corps of Engineers were among the lowest recorded since the impoundments were constructed. At B. Everett Jordan Lake in Chatham County, monthly inflows were less than 50 percent of monthly normals in 17 of 24 months (October 2000 through September 2002) and declined to less than 15 percent from May through July 2002. During the same period, monthly inflows to Falls Lake in Wake and Durham Counties were less than zero in 5 of 24 months (including May through July 2002), which means the monthly volume of water that evaporated from the lake exceeded inflows from the basin. At J.H. Kerr Reservoir near the North Carolina-Virginia State line, inflows were below the lowest monthly records since 1950 in 8 of the 12 months between October 2001 and September 2002.

The 1998-2002 drought caused widespread hardship and losses across North Carolina. During the latter months of 2002, nearly 250 municipalities, including most major cities, operated under some form of voluntary, mandatory, or emergency water-conservation restrictions. Emergency conservation was enforced in areas where insufficient or complete loss of water supply posed immediate threats to the community, resulting in drastic and unusual measures to maintain sufficient supplies. In general, the water-supply systems that were most affected were those that relied on river intakes and(or) had relatively small volumes of water-supply storage. Although above-normal rainfall returned starting in August and September 2002, more than 200 systems remained under some form of conservation through November 2002; however, many switched from mandatory to voluntary conservation while awaiting the longterm outcome from the rainfalls. By January 2003, hydrologic conditions had improved enough that most municipalities were no longer operating under water-conservation restrictions.

Economic losses from droughts are difficult to estimate. In 2002 alone, the costs for agriculture were estimated to be $\$ 398$ million and $\$ 15$ to 20 million for municipalities. These costs are for only 1 year of the drought and do not include costs associated with business or industry losses. The total estimated costs in North Carolina for the 1998-2002 drought were \$1 billion, although no specific information was available on which sectors were represented in this estimate. The lack of detailed costs for all affected sectors has emphasized the need for tracking costs associated with droughts. Nevertheless, costs associated with droughts are very high (average annual cost is $\$ 6$ to 8 billion for the United States) when compared with the average annual costs associated with floods ( $\$ 2.4$ billion) and hurricanes (\$1.2 to 4.8 billion).

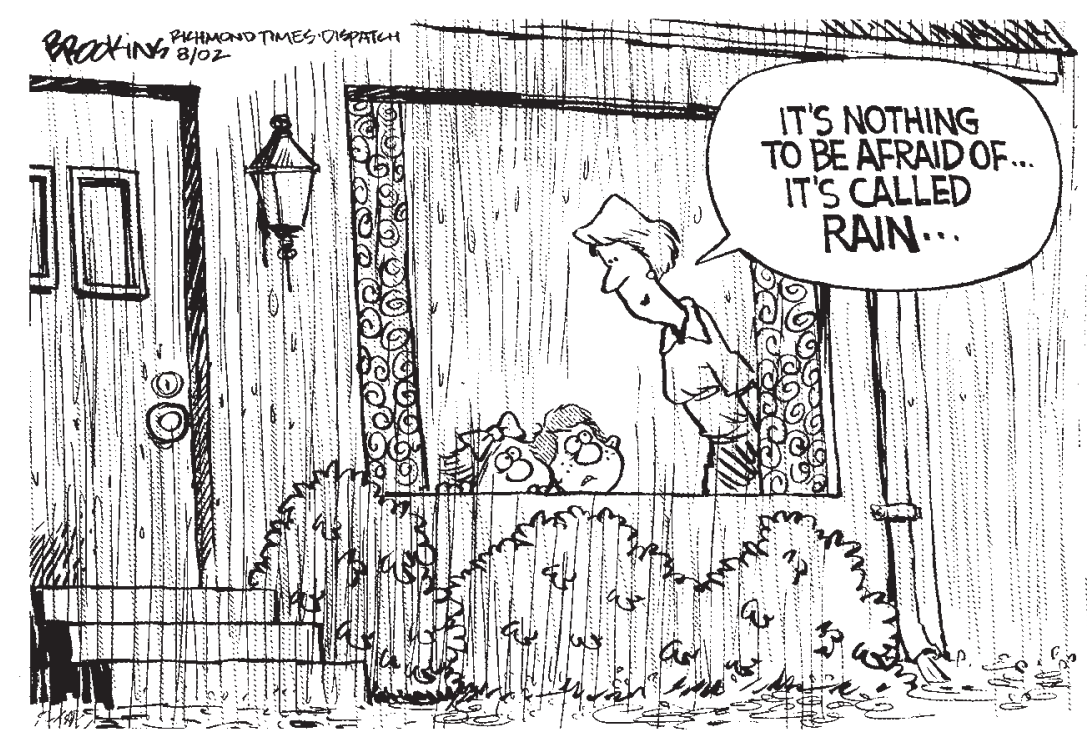

Editorial cartoon used with permission, by Gary Brookins, Richmond Times-Dispatch, August 29, 2002. 


\section{Selected References}

Bales, J.D., Oblinger, C.J., and Sallenger, A.H., Jr., 2000, Two months of flooding in eastern North Carolina, September-October 1999: Hydrologic, water-quality, and geologic effects of Hurricanes Dennis, Floyd, and Irene: U.S. Geological Survey Water-Resources Investigations Report 00-4093, 47 p.

Bales, J.D., Weaver, J.C., and Robbins, J.C., 2003, The drought of 19982002-North Carolina experiences [poster]: U.S. Geological Survey, 1 sheet.

Barber, N.L., and Stamey, T.C., 2000, Droughts in Georgia: U.S. Geological Survey Open-File Report 00-380, 2 p. Bosilovich, M.G., and Schubert, S.D., 2001, Precipitation recycling over the central United States diagnosed from the GEOS-1 data assimilation system: American Meteorological Society Journal of Hydrometeorology, v. 2, no. 1 , p. 26-35.

Daly, Christopher, Neilson, R.P., and Phillips, D.L., 1994, A statisticaltopographical model for mapping climatological precipitation over mountainous terrain: Journal of Applied Meteorology, v. 33, p. 140-158.

Daly, Christopher, Taylor, G.H., and Gibson, W.P., 1997, The PRISM approach to mapping precipitation and temperature, in Proceedings of the 10th Conference on Applied Climatology, Reno, Nev., Oct. 20-24, 1997: Boston, Mass., American Meteorological Society, p. 10-12.

Edwards, D.C., and McKee, T.B., 1997, Characteristics of 20th century drought in the United States at multiple time scales: Fort Collins, Colorado State University Climatology Report 97-2.

Federal Emergency Management Agency, 1995, National mitigation strategy-Building partnerships for safer communities: Washington D.C., $51 \mathrm{p}$.
Hale, T.W., Hopkins, E.H., and Carter, R.F., 1989, Effects of the 1986 drought on streamflow in Alabama, Georgia, North Carolina, South Carolina, Tennessee, and Virginia: U.S. Geological Survey Water-Resources Investigations Report 89-4212, 56 p.

Hall, B.R., 2003, Poverty's enduring tradition in rural North Carolina-How do we respond? in Popular Government, v. 68 , no. 3, Spring/Summer 2003: Institute of Government of The University of North Carolina at Chapel Hill, p. 25-31.

Hayes, M.J., Svoboda, M.D., Knutson, C.L., and Wilhite, D.A., 2004, Estimating the economic impacts of drought [abs.]: Proceedings of the 84th annual meeting of the American Meteorological Society, January 10-16, 2004, Seattle, Wash., J 2.6, 3 p.; accessed March 31, 2004, at http://ams.confex.com/ams/ 84Annual/techprogram/paper 73004. htm .

Heath, R.C., 1983, Basic ground-water hydrology: U.S. Geological Survey Water-Supply Paper 2220, 84 p.

Heim, R.R., Jr., 2002, A review of twentieth-century drought indices used in the United States: Bulletin of the American Meteorological Society, v. 83 , no. 8 (August 2002), p. 11491165.

Howe, S.S., and Breton, P.L., 1998, Water resources data, North Carolina, water year 1997, v. 2, ground-water records: U.S. Geological Survey Water-Data Report NC-97-2, 251 p.

Howe, S.S., and Breton, P.L., 1999, Water resources data, North Carolina, water year 1998, v. 2, ground-water records: U.S. Geological Survey Water-Data Report NC-98-2, 243 p.

Howe, S.S., Breton, P.L., and Chapman, M.J., 2003, Water resources data, North Carolina, water year 2002, v. 2, ground-water records: U.S. Geological Survey Water-Data Report $\mathrm{NC}-02-2,355 \mathrm{p}$.

Hoyt, J.C., 1936, Droughts of 1930-34: U.S. Geological Survey Water-Supply Paper 680, 106 p.
Karl, T.R., and Knight, R.W., 1985, Atlas of monthly Palmer Hydrological Drought Indices (1931-1983) for the contiguous United States: Asheville, N.C., National Climatic Data Center, Historical Climatology Series 3-7.

Knight Publishing Company, 2002, Who gets the water? The Carolinas face new limits as growth outpaces supply: news article by Bruce Henderson appearing in The Charlotte Observer, December 29, 2002; accessed February 4, 2004, from online archives at http://www.charlotte.com/mld/ charlotte/news/4833197.htm .

Langbein, W.B., and Iseri, K.T., 1960, General introduction and hydrologic definitions: U.S. Geological Survey Water-Supply Paper 1541-A, 29 p.

Moreland, J.A., 1993, Drought: U.S. Geological Survey Open-File Report 93-642, 2 p.

National Drought Mitigation Center, 2003a, Drought monitor-State-ofthe-art blend of science and subjectivity; accessed December 16, 2003, at http://drought.unl.edu/dm/classify. htm .

National Drought Mitigation Center, 2003b, Understanding your risk; accessed April 9, 2004, at http:// drought.unl.edu/risk/risk.htm .

National Drought Mitigation Center, 2003c, What is drought? accessed December 1, 2003, at http://drought. unl.edu/whatis/what.htm .

National Oceanic and Atmospheric Administration, 2001, Drought determination and amelioration background: National Climatic Data Center; accessed March 2, 2004, at http://lwf.ncdc.noaa.gov/oa/climate/ research/drought/background.html .

National Oceanic and Atmospheric Administration, 2002, The ENSO cycle-Climate Prediction Center; accessed February 24, 2004, at http:// www.cpc.ncep.noaa.gov/products/ analysis monitoring/ensocyclel enso cycle.html. 
National Oceanic and Atmospheric Administration, 2003a, Climatological data, North Carolina, October 2002: National Oceanic and Atmospheric Administration, v. 107, no. 10, $36 \mathrm{p}$.

National Oceanic and Atmospheric Administration, 2003b, North American drought - A paleo perspective, The last 500 years; accessed March 2, 2004, at http://www.ncdc.noaa.gov/ paleo/drought/drght 500years.html.

National Oceanic and Atmospheric Administration, 2004a, Climate of 2004-January U.S. Palmer Drought Indices: National Climatic Data Center; accessed December 2, 2004, at http://lwf.ncdc.noaa.gov/oa/climatel research/prelim/drought/palmer.html .

National Oceanic and Atmospheric Administration, 2004b, Climate of 2004-January North Carolina drought: National Climatic Data Center; accessed December 2, 2004, at http://lwf.ncdc.noaa. gov/oa/climate/research/2004/jan/ st031dv00pcp200401.html.

News and Observer Publishing Company, 2001, Drought grips western half of state: news article by Bob Williams in The News and Observer, March 17, 2001; accessed February 25, 2004, from online archives at http://www.newsbank.com/.

News and Observer Publishing Company, 2002a, Some taps could run dry this week: news article by Dan Egbert in The News and Observer, August 12, 2002; accessed August 26, 2004 , from online archives at $h t t p: / / w w w$. newsbank.com/.

News and Observer Publishing Company, 2002b, Stage 3 restrictions may be close: news article by Dave Hart in The Chapel Hill News, August 25, 2002; accessed February 25, 2004, from online archives at $\underline{h t p: / / w w w}$. newsbank.com/.

News and Observer Publishing Company, 2002c, Towns desperate for water: news article by Jay Price and Molly Hennessy-Fiske in The News and Observer, August 11, 2002; accessed August 26, 2004, from online archives at http://www. newsbank.com/.
News and Observer Publishing Company, 2002d, Water scramble: news article by Dan Egbert in The News and Observer, August 21, 2002; accessed February 25, 2004, from online archives at http://www.newsbank.com/.

North Carolina Department of Agriculture, 2002, Letter from the North Carolina Commissioner of Agriculture to the President of the United States, dated November 14, 2002; accessed April 8, 2004, at http://www. ncagr.com/georgebush11-15-02.doc.

North Carolina Department of Environment and Natural Resources, 2002, Environmental agency offers water conservation assistance to business and industry in drought-affected North Carolina counties: press release dated July 23, 2002; accessed August 25, 2004, at http://www.enr.state. nc.us/newsrels/20020723 Drought Assist.html .

North Carolina Division of Water Resources, 2004, Drought indicator wells: North Carolina Drought Management Advisory Council; accessed March 18, 2004, at http://www.ncwater.org/drought/wells.php .

North Carolina Rural Economic Development Center, 2002, Rural Center awards \$3.2 million to droughtstricken communities, joins with Gov. Easley and state agencies to address water shortages: press release dated December 12, 2002; accessed February 12, 2004, at http://www.ncruralcenter.org/news/ pr.asp?Release $I D=66$.

Pal, J.S., and Eltahir, E.A.B., 2001, Pathways relating soil moisture conditions to future summer rainfall within a model of the land-atmosphere system: American Meteorological Society Journal of Climate, v. 14, no. 6, p. 1227-1242.

Paulachok, G.N., Krejmas, B.E., and Soden, H.L., 2000, Hydrologic aspects of the 1998-99 drought in the Delaware River basin: U.S. Geological Survey Water-Resources Investigations Report 00-4112, 29 p.
Ragland, B.C., Barker, R.G., and Robinson, J.B., 2003, Water resources data, North Carolina, water year 2002, v. 1B, surface-water records: U.S. Geological Survey Water-Data Report, NC-02-1B, 645 p.

Ragland, B.C., Barker, R.G., and Robinson, J.B., 2004, Water resources data, North Carolina, water year 2003, v. 1B, surface-water records: U.S. Geological Survey Water-Data Report, NC-03-1B, 773 p.

Ragland, B.C., Smith, D.G., Barker, R.G., and Robinson, J.B., 1998, Water resources data, North Carolina, water year 1997, v. 1, surface-water records: U.S. Geological Survey Water-Data Report NC-97-1, 544 p.

Ragland, B.C., Walters, D.A., Cartano, G.D., and Taylor, J.E., 2003, Water resources data, North Carolina, water year 2002, v. 1A, surface-water records: U.S. Geological Survey Water-Data Report, NC-02-1A, 534 p.

Ragland, B.C., Walters, D.A., Cartano, G.D., and Taylor, J.E., 2004, Water resources data, North Carolina, water year 2003, v. 1A, surface-water records: U.S. Geological Survey Water-Data Report, NC-03-1A, $701 \mathrm{p}$.

Riggs, H.C., 1972, Low-flow investigations: U.S. Geological Survey Techniques of Water-Resources Investigations, book 4, chap. B1, 15 p.

Ropelewski, C.F., and Halpert, M.S., 1986, North American precipitation and temperature patterns associated with the El Niño-Southern Oscillation (ENSO): American Meteorological Society Monthly Weather Review, v. 114, no. 12 (December 1986), p. 2352-2362.

Spatial Climate Analysis Service, 2004, Precipitation-Annual climatology (1971-2000): Oregon State University; accessed August 23, 2004, at http://www.ocs.orst.edu/prism/index. phtml.

State Climate Office of North Carolina, 2003, Table of all cooperative observer stations in North Carolina: accessed October 14, 2003, at http:// www.nc-climate.ncsu.edu/services/ all stations.html. 
State of North Carolina Office of the Governor, 2002a, Governor Easley announces over $\$ 20$ million for water supply enhancement projects: press release dated September 30, 2002; accessed August 25, 2004, at http://www.governor.state.nc.us/ News/PressReleases/PressRelease. asp? YR=2002\&MN=09-September \& $F N=30 \% 2$ gov $\% 2 E+$ easley + announ ces+over $+\% 2420 m+$ for + water + supp ly+enhancement + projects $\% 2 \mathrm{Exml}$.

State of North Carolina Office of the Governor, 2002b, State agencies continue actions to protect water supply: press release dated August 23, 2002; accessed April 12, 2004, at http://www.ncgov.com/asp/subpages/ news release view.asp?nrid $=286$.

Treece, M.W., Jr., and Bales, J.D., 1990, North Carolina water supply and use, in National Water Summary, 1987-Hydrologic events and water supply and use: U.S. Geological Survey Water-Supply Paper 2350, p. 393-400.
U.S. Census Bureau, 2001, Ranking tables for states-Population in 2000 and population change from 1990 to 2000 (PHC-T-2); accessed August 25, 2004, at http://www.census.gov/ population/www/cen2000/ phc-t2.html .

U.S. Fish and Wildlife Service, 2004, North Carolina man sentenced for theft of water from Mattamuskeet National Wildlife Refuge: press release dated January 22, 2004; accessed August 25, 2004, at http:// southeast.fws.gov/news/2004/r04-006. html.

U.S. Geological Survey, 2004, Ground Water Climate Response Network; accessed March 10, 2004, at http:// groundwaterwatch.usgs.gov/.

Walters, D.A., 1997, Estimated water use, by county, in North Carolina, 1995: U.S. Geological Survey OpenFile Report 97-599, 102 p.
Weaver, J.C., and Fine, J.M., 2003, Low-flow characteristics and profiles for the Rocky River in the YadkinPee Dee River basin, North Carolina, through 2002: U.S. Geological Survey Water-Resources Investigations Report 03-4147, 50 p.

Western Governors' Association, 2004, Drought initiatives-National Drought Preparedness Act of 2003; accessed April 9, 2004, at http://www. westgov.org/wga/initiatives/drought2. htm.

Willeke, G., Hosking, J.R.M., Wallis, J.R., and Guttman, N.B., 1994, The national drought atlas: U.S. Army Corps of Engineers, Institute for Water Resources Report 94-NDS-4, $587 \mathrm{p}$.

Zembrzuski, T.J., Jr., Hill, C.L., Weaver, J.C., Coble, R.W., and Gunter, H.C., 1991, North Carolina floods and droughts, in National Water Summary 1988-89-Hydrologic events and floods and droughts: U.S. Geological Survey Water-Supply Paper 2375, p. $425-434$. 


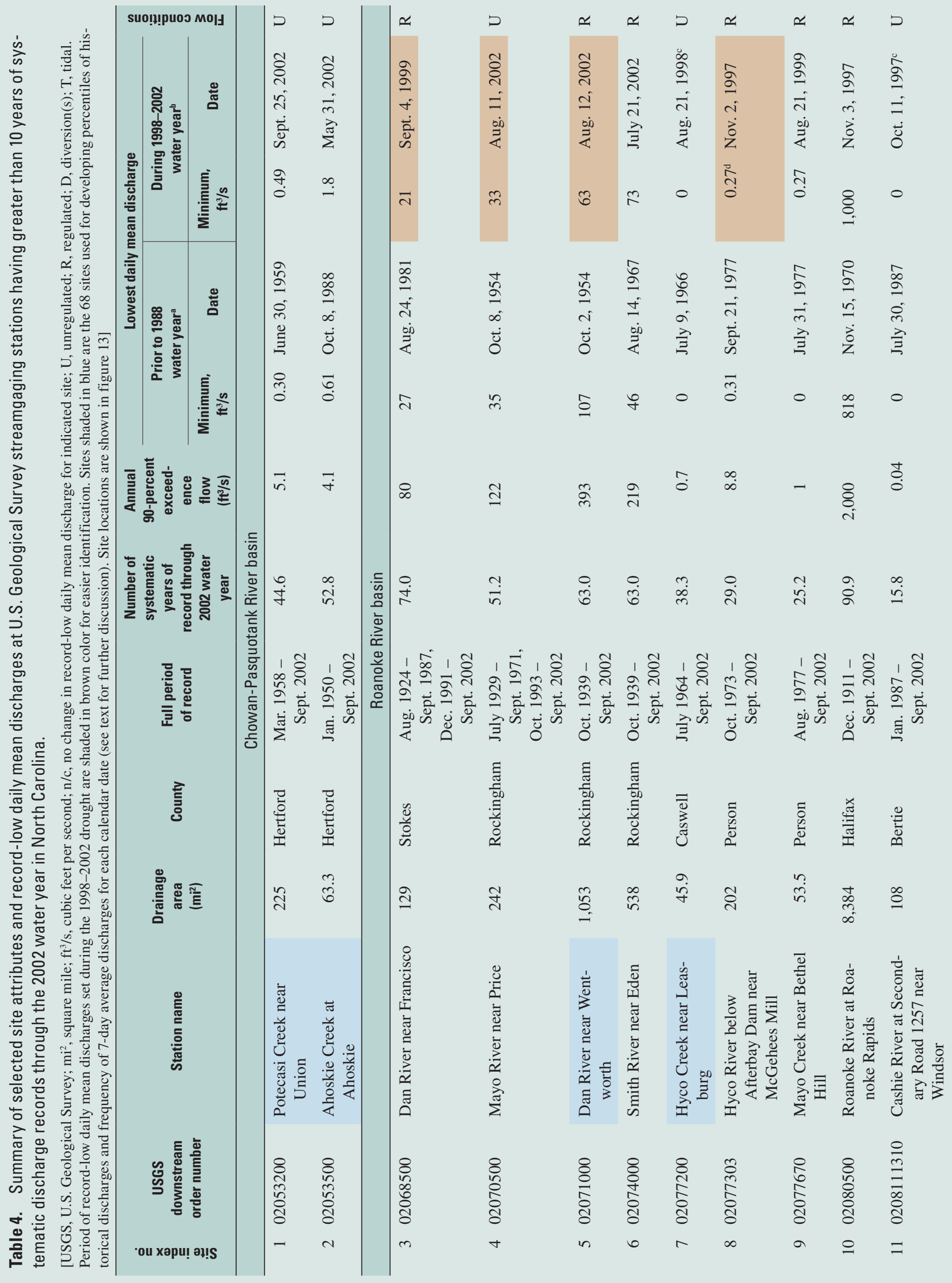




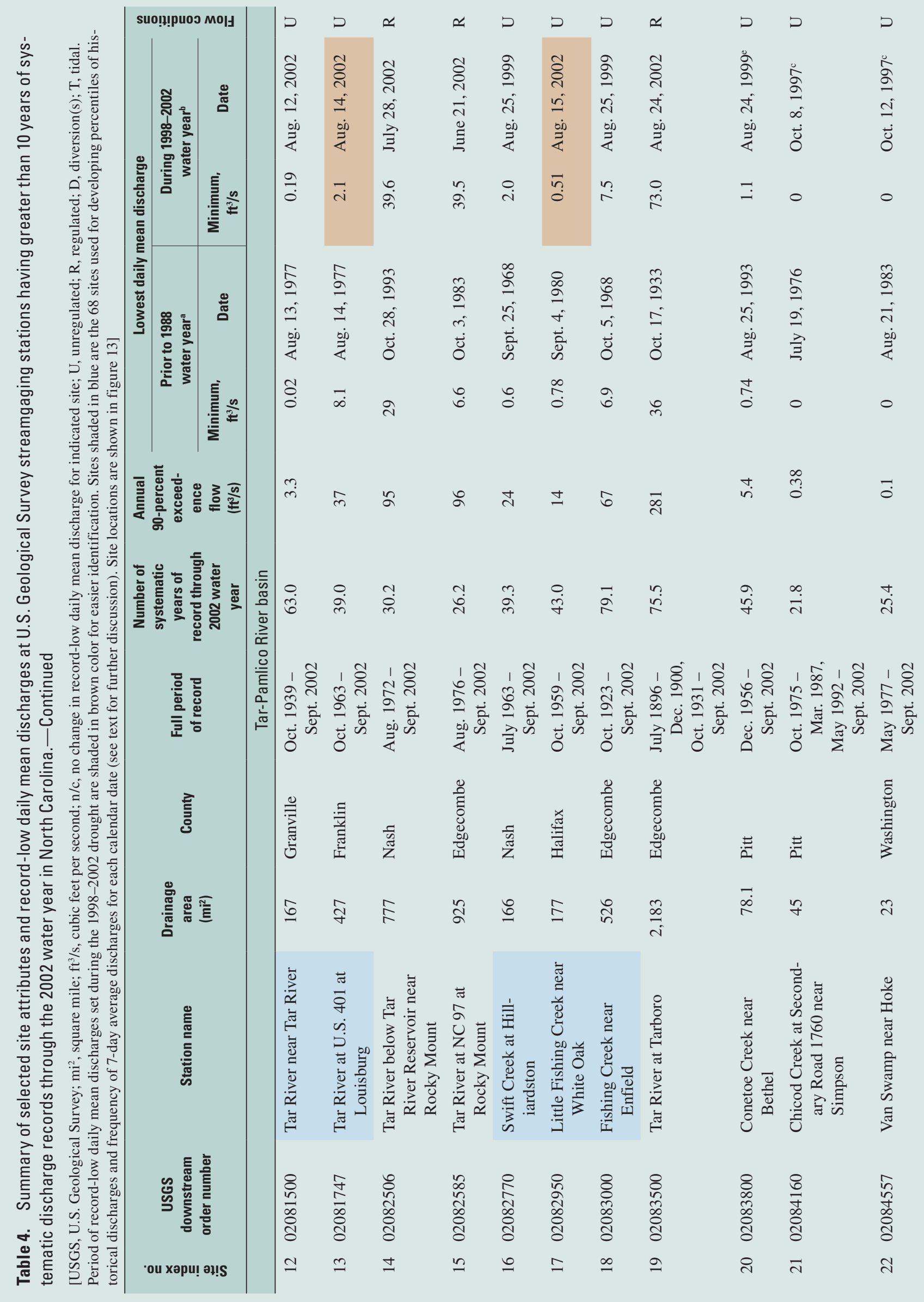




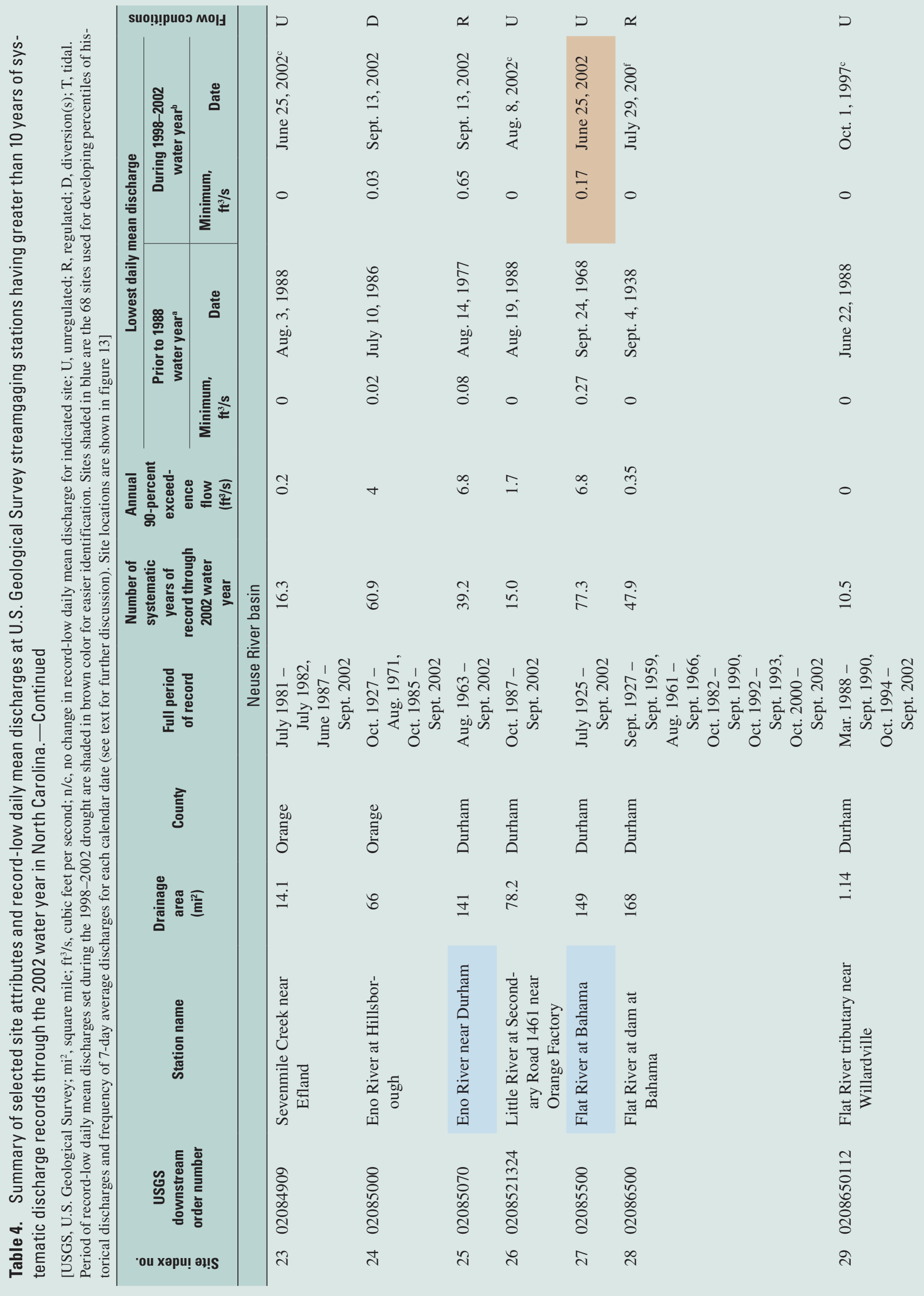









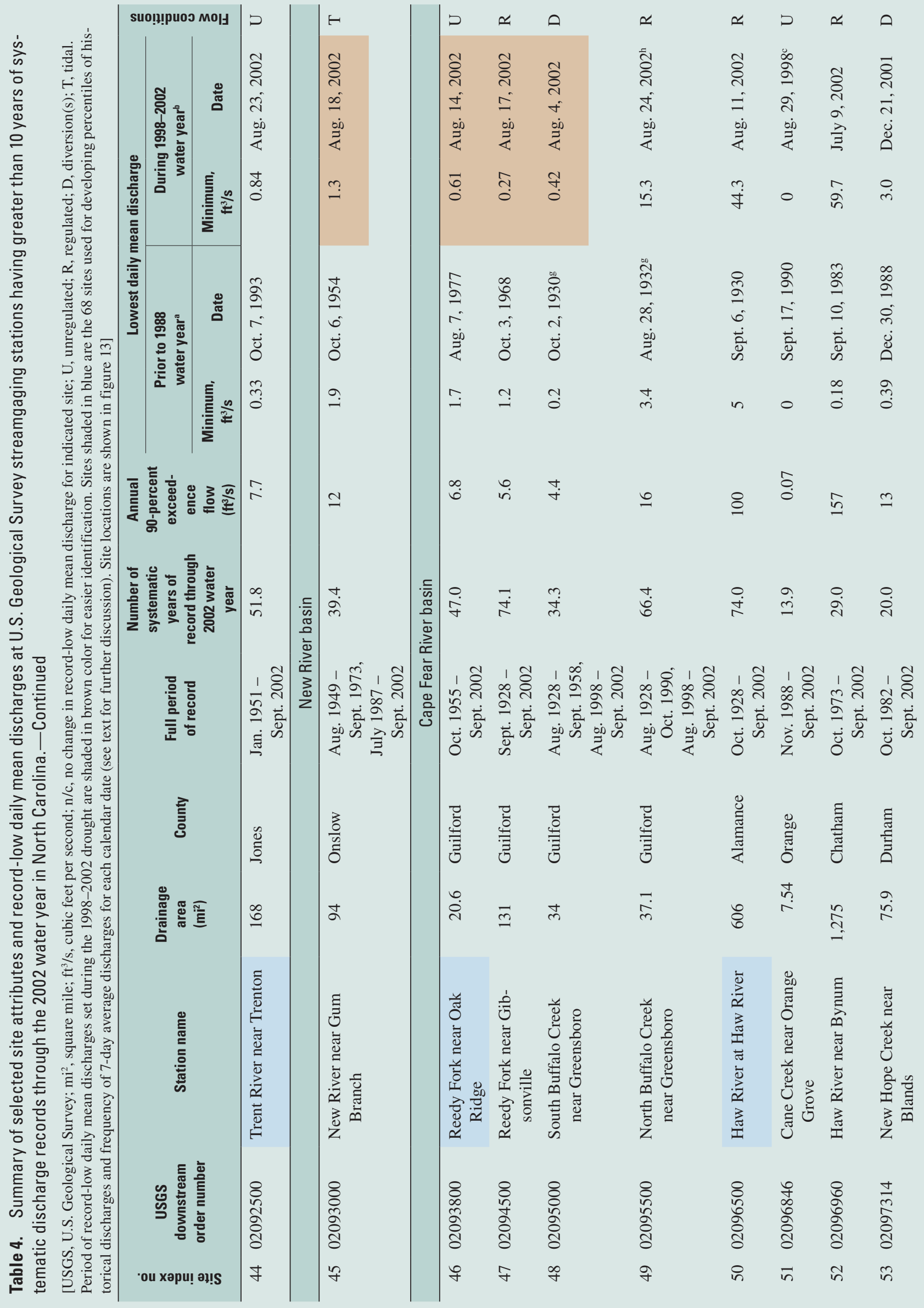




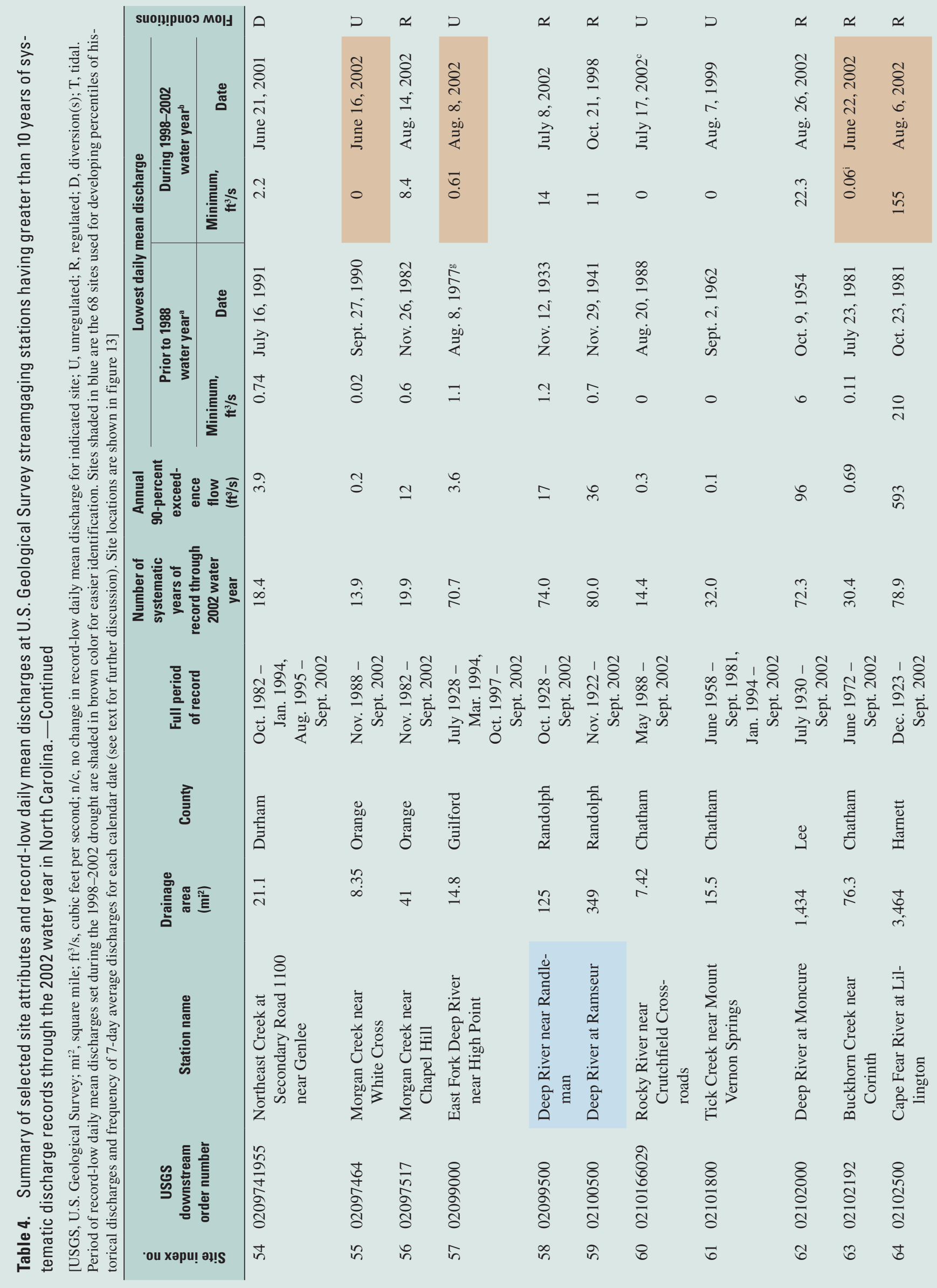




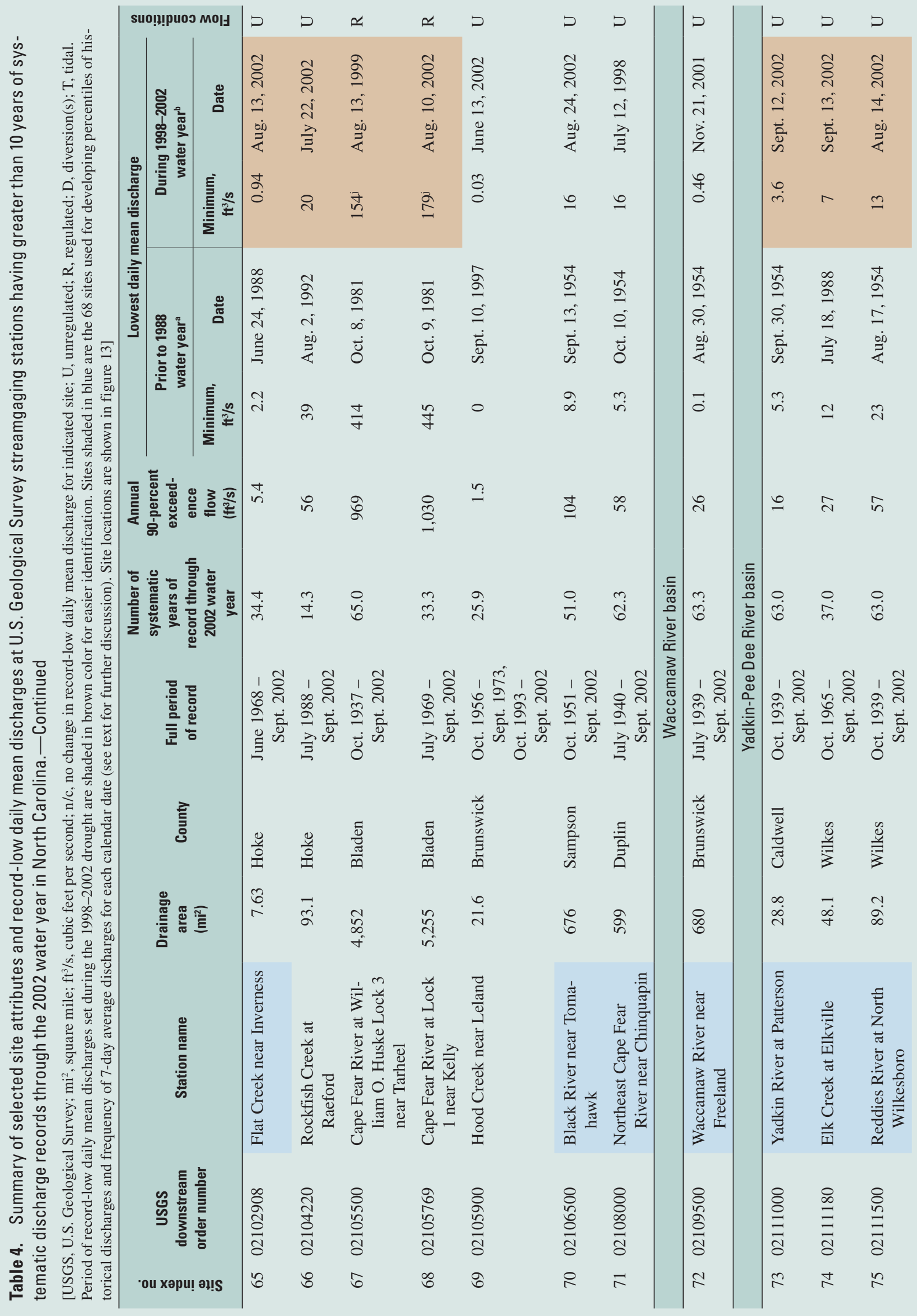




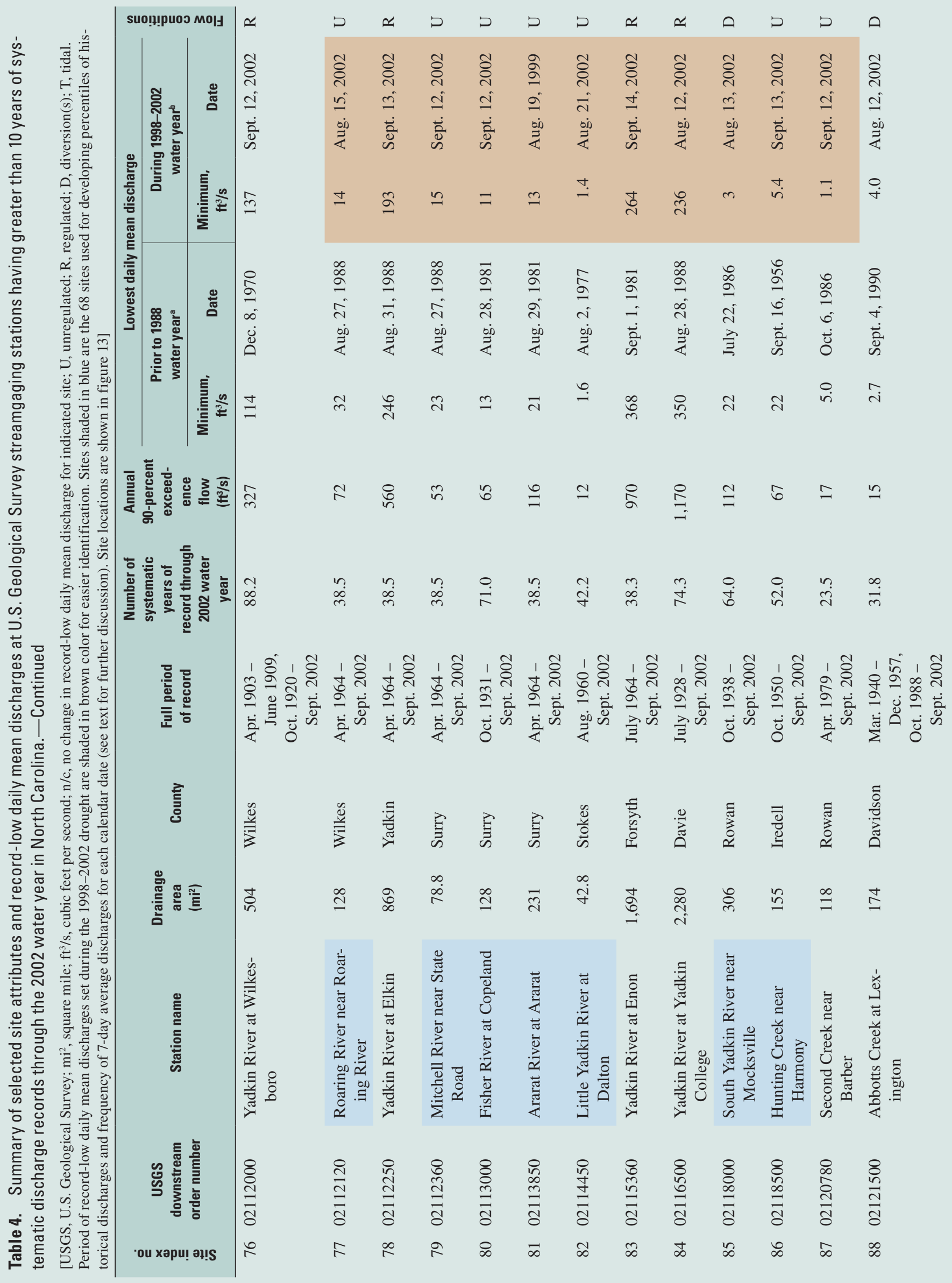




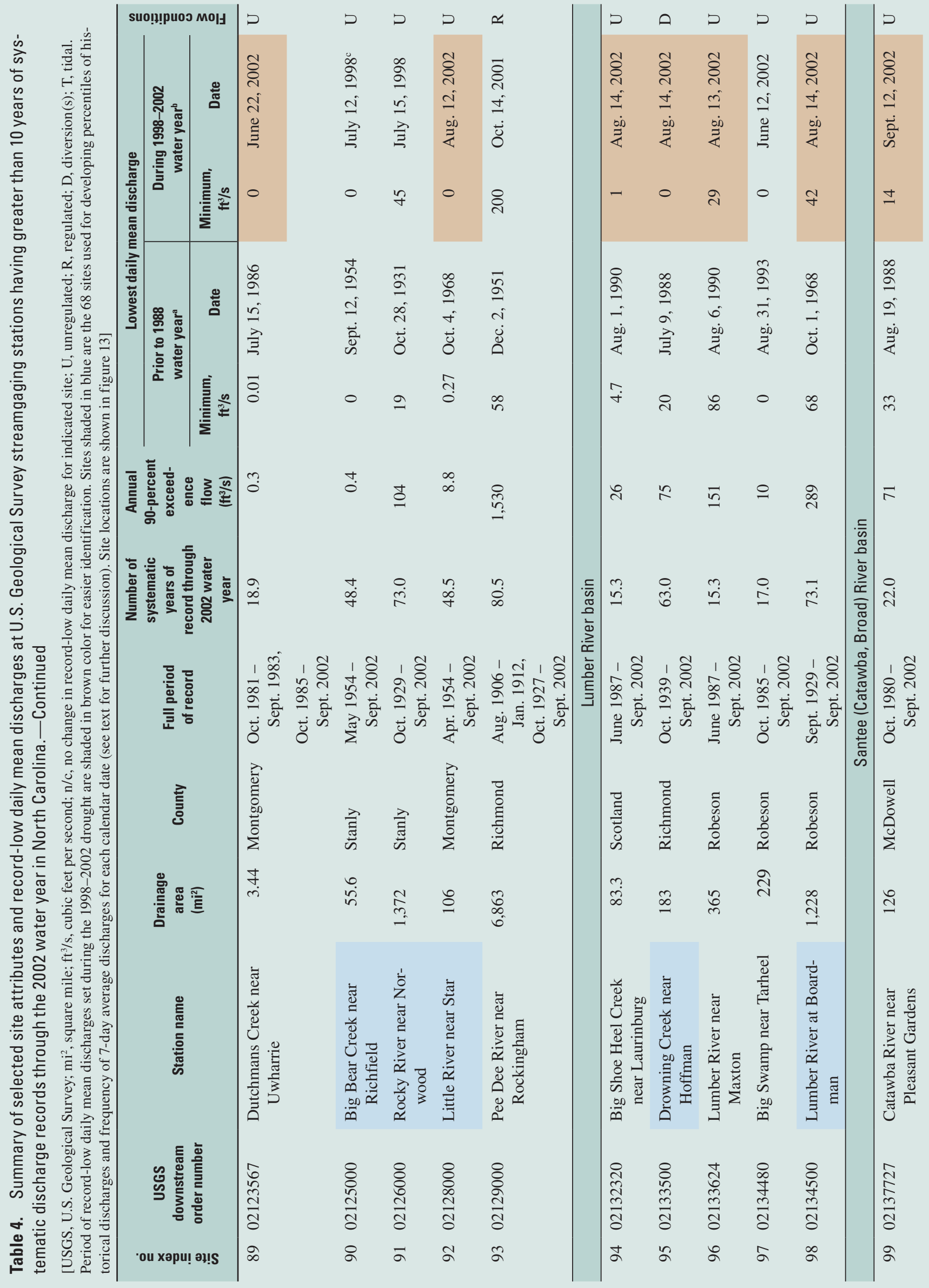









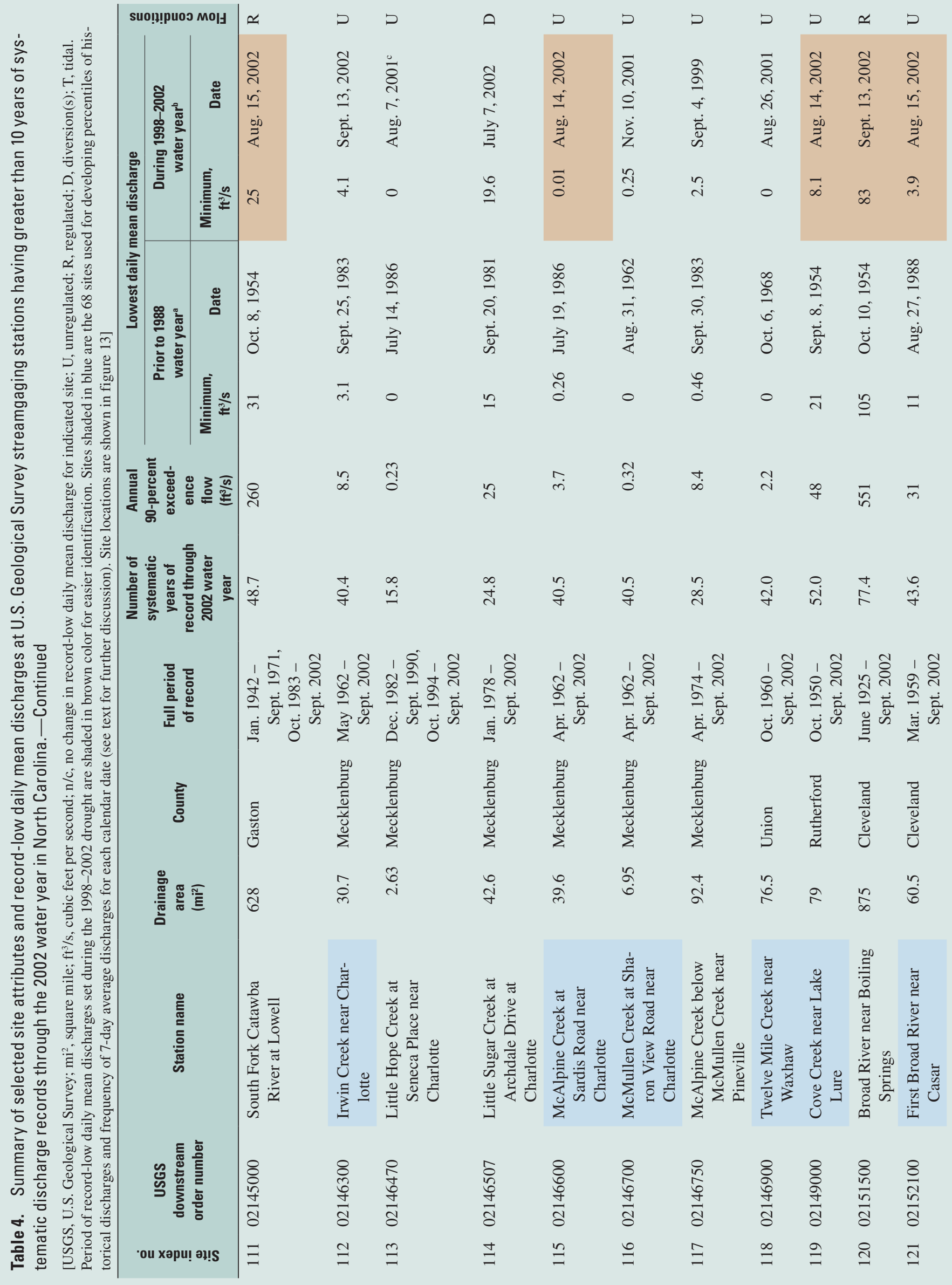




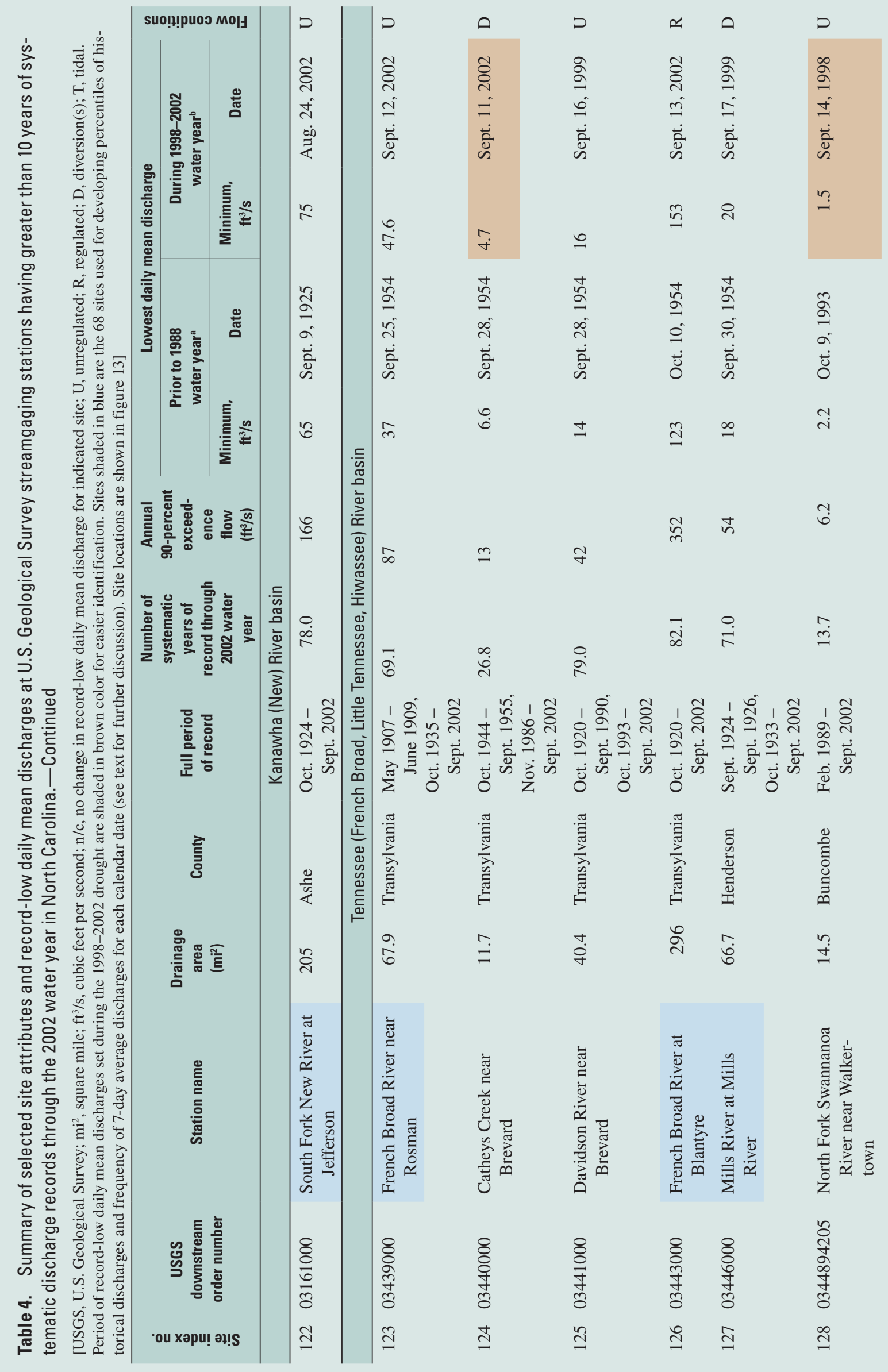




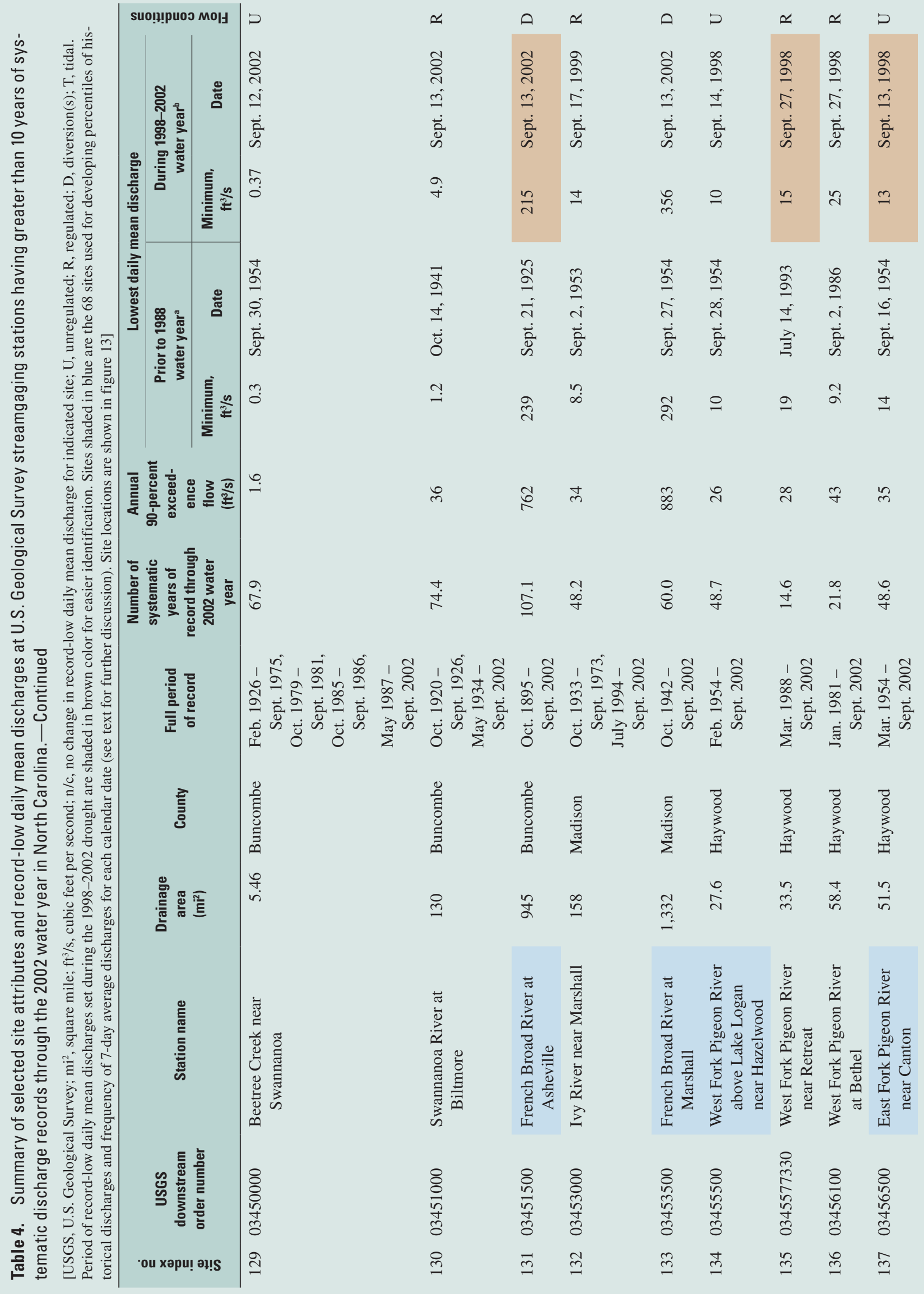




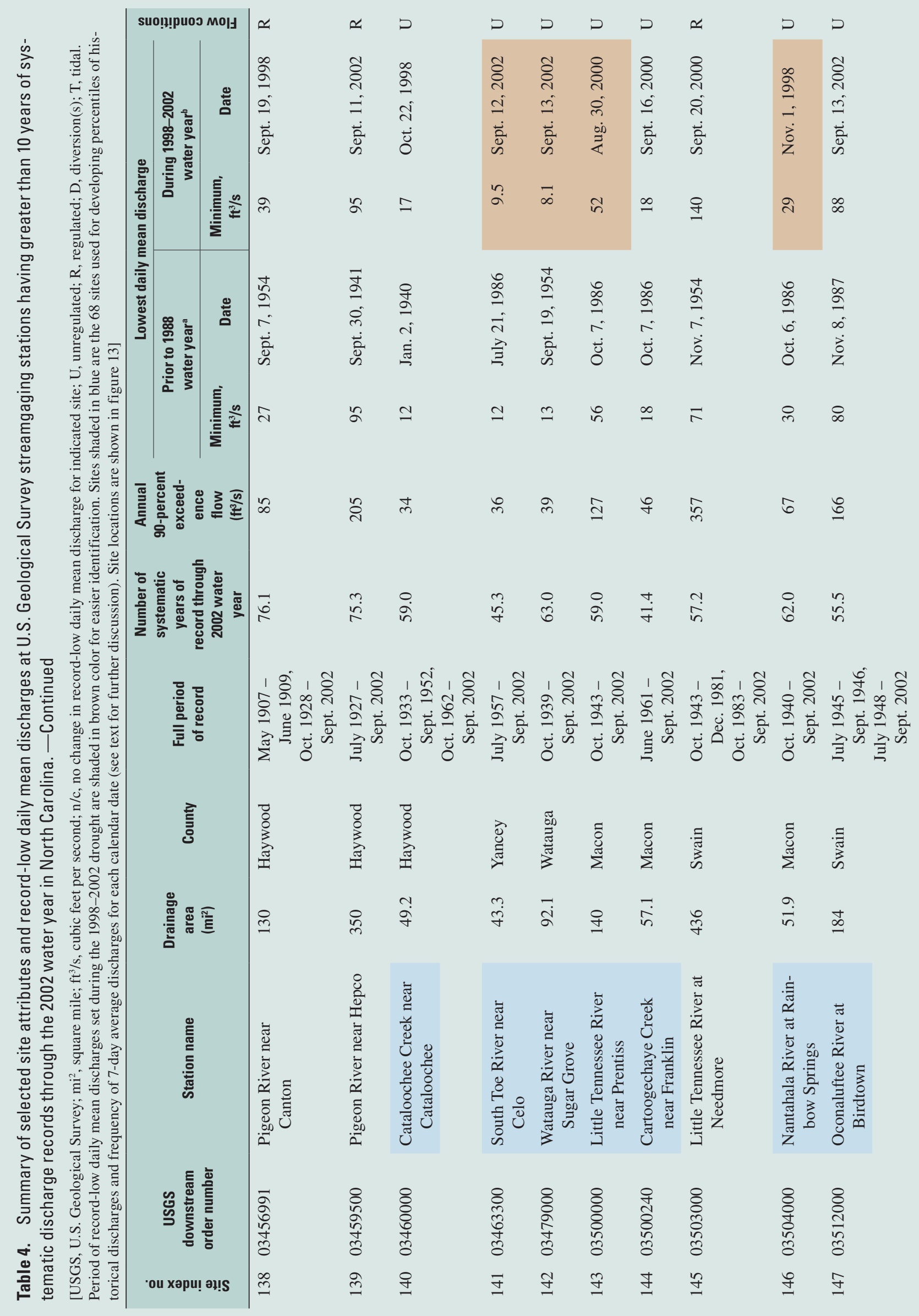




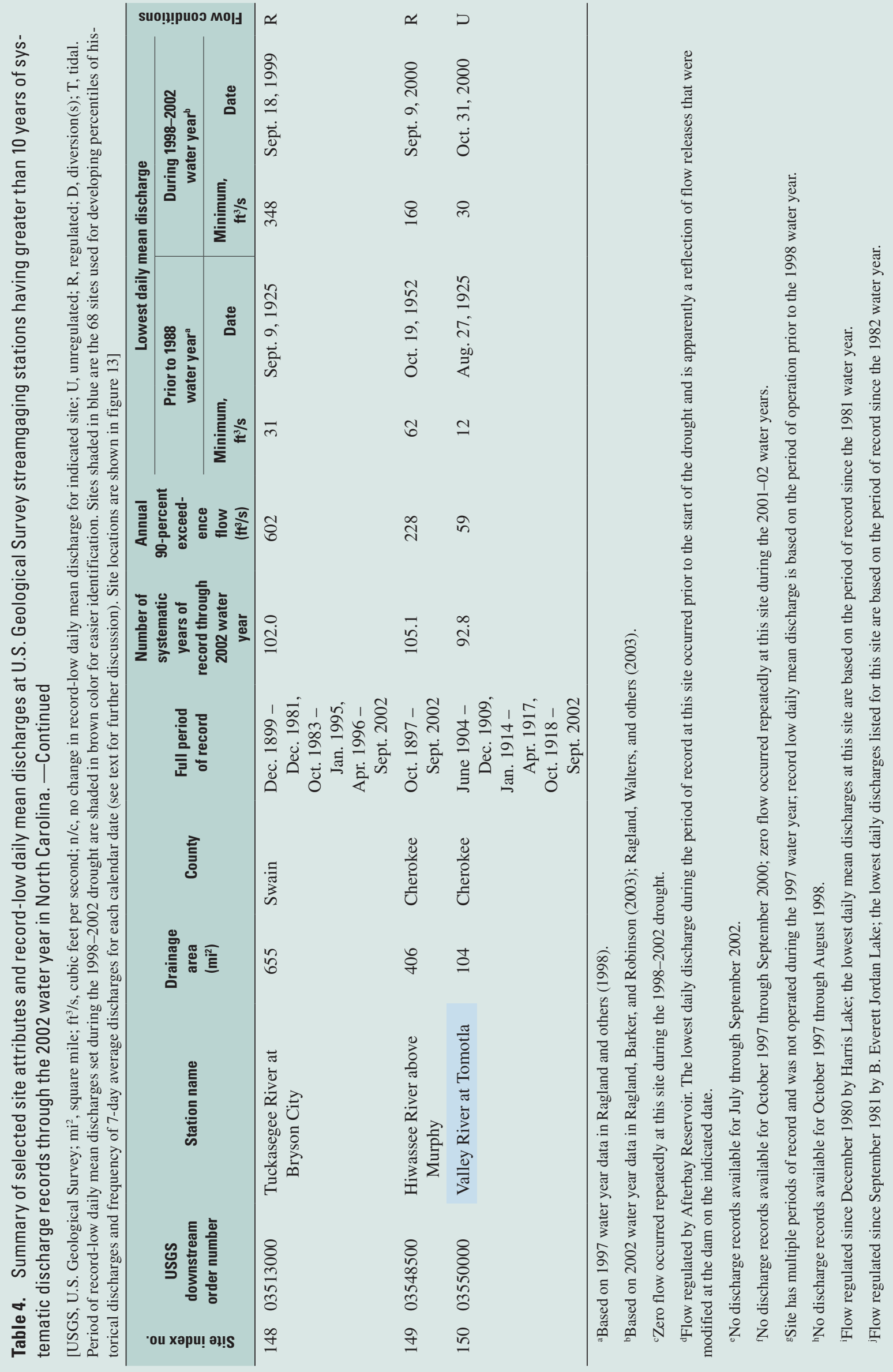


Photographs in this report are used with permission.

This report was prepared by the North Carolina Water Science Center, Raleigh, N.C. Edited by Rebecca J. Deckard and Kay E. Hedrick. Graphics by Jeffrey L. Corbett. 

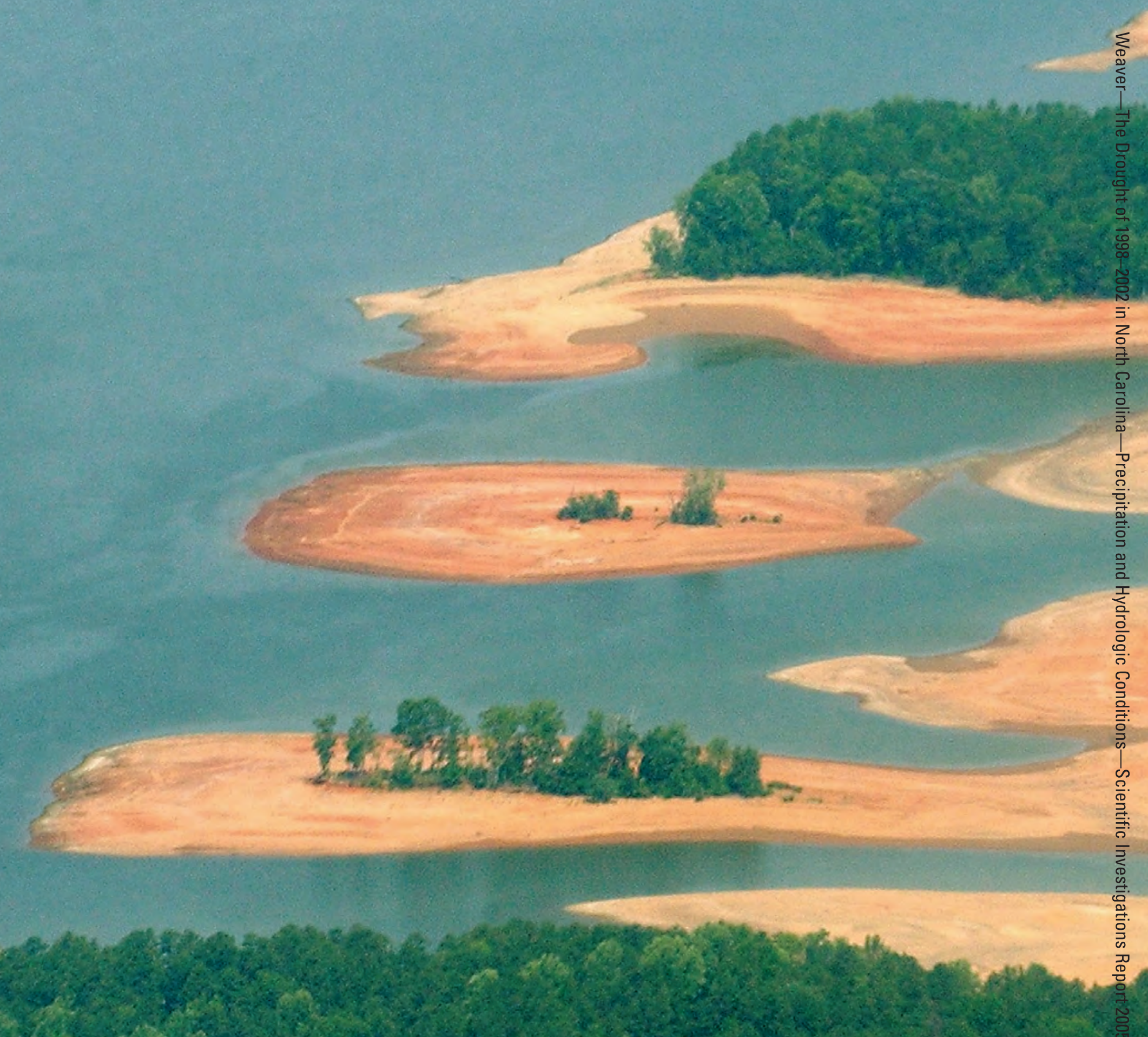
20.

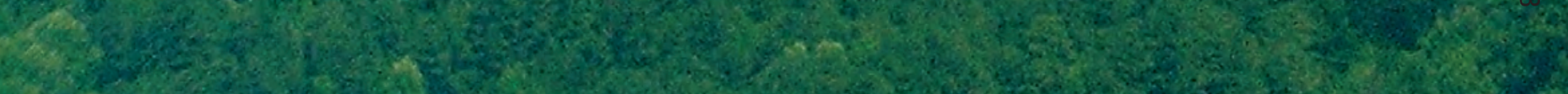

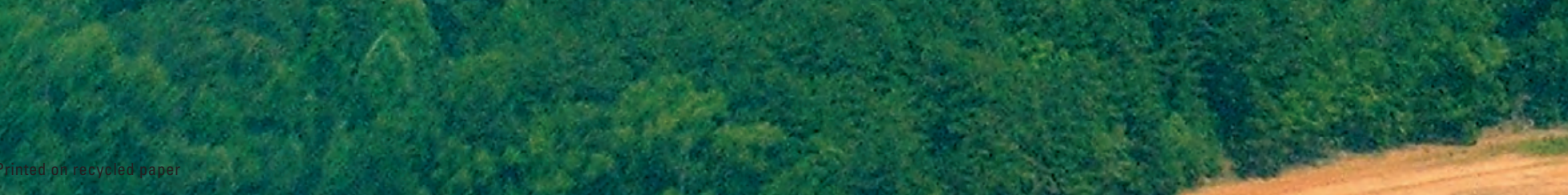

